WERNER GRAU NETO

A POLÍTICA NACIONAL SOBRE MUDANÇA DO CLIMA E SUA IMPLEMENTAÇÃO PARA OS SETORES DE ENERGIA E FLORESTAS - MECANISMOS TRIBUTÁRIOS

TeSe De Doutorado

Orientador: Professor Associado Heleno TaVeira TôRres

FACULDADE DE DIREITO DA USP

SÃO PAULO

2012 


\title{
A POLÍTICA NACIONAL SOBRE MUDANÇA DO CLIMA E SUA IMPLEMENTAÇÃO PARA OS SETORES DE ENERGIA E FLORESTAS - MECANISMOS TRIBUTÁRIOS
}

\author{
Tese de Doutorado apresentada à Banca Examinadora da Faculdade \\ de Direito da Universidade de São Paulo, como exigência parcial \\ para a obtenção do título de Doutor em Direito, sob a orientação do \\ Prof. Associado Heleno Taveira Tôrres
}

FACULDADE DE DIREITO DA USP

SÃO PAULO

2012 
"À memória de meus avós queridos, Werner, Dalva, Helio e Mariinha, e dos tantos animais vítimas da estupidez humana." 


\section{AGRADECIMENTOS}

Ao Professor Heleno Tôrres, cujo estímulo foi fundamental a que este trabalho se materializasse.

Tércio, Andrea, José Roberto, Décio, Lucas, Jorge, André, Josemar, Renato e Angela pela ajuda de inestimável valor.

Ana e Bia, pela paciência e apoio. 


\section{RESUMO}

Desde o estabelecimento dos primeiros instrumentos legais voltados à proteção ambiental, no Brasil, até os dias atuais, desenvolveu-se sistema de controle e proteção do meio ambiente calcado, primordialmente, no princípio da prevenção, materializando-se sua aplicação por meio do mecanismo de comando e controle, do qual é expressão maior, em nosso sistema, o licenciamento ambiental.

A ferramenta escolhida pelo legislador, na esmagadora maioria dos casos, para garantia ao atendimento das regras de cunho ambiental, foi a da aplicação do princípio do poluidor-pagador, por meio da qual se busca internalizar o custo ambiental gerado pelo empreendedor.

De perfil eminentemente reativo, pontual e revelador de uma postura de adequação da atividade potencialmente degradadora do meio ambiente à vontade social através da adoção de sistemas compensatórios, o princípio do poluidor-pagador, inserido no sistema de comando e controle, leva à limitação da eficiência do sistema: a uma, porque a estrutura de comando e controle é extremamente demandante ao Estado, impondo-lhe custos e peso que tendem, em um ambiente de forte industrialização, à paquidermia, à falta de especialização, aos desvios, e à ineficiência.

A duas, a aplicação do binômio prevenção + internalização de custos encerra, em si mesma, um limitador que trava e impede sua eficiência: a análise do potencial degradador/poluidor da intervenção humana sobre o ambiente tende a ser pontual, impedindo uma visão abrangente e a aplicação ampla e coordenada de políticas públicas sob uma visão e alcance holísticos.

Mais ainda, a limitação da aplicação do ferramental de proteção e controle ambiental à esfera pontual opera contra o alcance da materialização do princípio da sustentabilidade, vetor central de nossa estrutura constitucional de proteção ambiental.

Nesse contexto, parece necessário revisitar nossa sistemática de proteção e controle ambiental, para propor a utilização de mecanismos que proporcionem uma visão ampla, geral, e não pontual, de nossas atividades econômicas que interagem com o meio ambiente, 
de forma a que possamos complementar os mecanismos estabelecidos pela aplicação dos princípios da prevenção e do poluidor-pagador com medidas adicionais de perfil integrador, prestigiando políticas públicas e buscando a materialização do princípio da sustentabilidade.

Nossa visão é de que essa tarefa se faz possível pelo uso dos tributos como elemento de indução de condutas e posturas, tomada sua aplicação não mais de forma pontual e pelo viés do incentivo fiscal, mas sim pela criação de ambientes, aos setores da economia, em que a adoção de determinadas tecnologias, modo de produção ou trato dos riscos ambientais sejam induzidos e escolhidos pelo capital de investimento naturalmente. Complementa-se portanto o ferramental já existente, de controle, prevenção e repressão, pela adoção de um sistema de indução de ordem geral, e não meramente pontual.

A forma de estabelecimento dos mecanismos adequados a esse mister, em nossa opinião, é o da análise das políticas públicas de ordem ambiental de forma transversal a outras políticas públicas, e mesmo em relação a outras políticas públicas de ordem ambiental.

A proposição que trazemos é a do uso de mecanismos tributários para materialização desse objetivo, escolhendo para tanto a figura da CIDE como ferramenta adequada. O exemplo que elegemos foi o da consideração da Política Nacional sobre Mudança do Clima como política pública a ser considerada, de maneira transversal, à Política Energética Nacional e à Política Florestal.

Palavras-chave: sustentabilidade, tributos ambientais. 


\section{ABSTRACT}

Since the inception of the first legal instruments aimed at environment protection in Brazil, the country's environmental control and protection system has primarily relied on the prevention principle, and its enforcement has taken shape through a command and control mechanism that is epitomized, in the Brazilian system, by environmental licensing activity.

In the vast majority of cases, to ensure compliance with environmental rules, the lawmaker has opted to enforce the polluter-pay principle, as a means of obtaining compensation for the environmental harm caused by the undertaker.

The polluter-pay principle - which is eminently reactive, occasional and prone to conforming potentially degrading activity to the social will by adopting compensatory systems - within the command and control system weakens the efficacy expected from the whole system.

First, because the command-control structure is extremely demanding and imposes on the State substantial costs and weight that tend, in a highly industrialized environment, to result in sluggishness, lack of focus, abuses and inefficiency.

Second, the limitation posed by this binomial approach (prevention + compensation of costs) reins in its own efficacy, in that an analysis of the potential degradation/pollution caused by human intervention in the environment tends to be occasional, which prevents a more comprehensive view or the far-reaching and concerted adoption of public policies under a more holistic view and reach.

Further, this limitation ensuing from the adoption of current environmental protection and control tools to occasional circumstances ends up working against the materialization of the principle of sustainability, which is the cornerstone of our constitutional environment protection structure.

Within this context, it is necessary to revisit the Brazilian environmental protection and control system and suggest the use of other mechanisms that allow for a more general, far-reaching and non-occasional view on our economic activities that intertwine with the 
environment, so that we may supplement the mechanisms deriving from the prevention and polluter-pay principles with additional converging measures that would eventually attach greater importance to public policies and bring the sustainability principle into a palpable reality.

In our opinion, this is possible by using taxes as a means of inducing an expected behavior and conduct, but not levying them occasionally or as a tax incentive, but rather as a mechanism to create an environment for economic players where the use of specific technologies, production methods or environmental risk management procedures would be fostered and naturally chosen by investors. To that end, the control-prevention-curbing mechanisms already in place would be supplemented by a general (non-occasional) inducement system.

The way of implementing these adequate mechanisms, in our opinion, is by analyzing the public environmental policies vis-à-vis other public policies, and even as regards other public environmental policies.

What is thus being suggested is the use of tax mechanisms to attain this objective, electing the Contribution on Economic Activities (CIDE) as the most suitable tool to that end. The example addressed in this work was the Brazilian National Policy on Climate Change as a public policy to be taken into consideration vis-à-vis the Brazilian National Energy Policy and the Forest Policy.

Keywords: sustainability, environmental taxation 


\section{RÉSUMÉ}

Depuis la création des premiers instruments juridiques visant à protéger l'environnement au Brésil jusqu'à aujourd'hui, s'est développé un système de contrôle et de protection de l'environnement qui se repose essentiellement sur le principe de la prévention, sa matérialisation se réalisant par le mécanisme de commandement et de contrôle, dont la plus haute expression dans notre système est l'octroi de licences environnementales.

L'outil choisi par le législateur, dans l'écrasante majorité des cas, pour garantir le respect aux règles liées à l'environnement, a été l'application du principe pollueur-payeur, par lequel on cherche à internaliser les coûts environnementaux générés par l'entrepreneur.

Ayant un profil éminemment réactif, ponctuel et révélateur d'une position d'adéquation de l'activité potentiellement polluante de l'environnement à la volonté sociale par l'adoption de systèmes de compensation, le principe pollueur-payeur, inséré dans le système de commandement et de contrôle, conduit à une limitation de l'efficacité du système : d'abord, car la structure de commandement et de contrôle est extrêmement lourde à l'Etat et lui impose des coûts et un poids qui ont une tendance, dans un environnement d'industrialisation intense, à la morosité, au manquement de spécialisation, aux déviations et à l'inefficacité.

Ensuite, car l'application du binôme prévention + internalisation de coûts renferme un facteur de limitation qui bloque et empêche son efficacité : l'examen du potentiel dégradateur/pollueur de l'intervention humaine dans l'environnement tend à être ponctuel, ce qui empêche une vision large et l'application ample et coordonnée de politiques publiques selon une vision et une étendue holistiques.

Et encore, la limitation de l'application des outils de protection et de contrôle de l'environnement à la sphère ponctuelle se produit contre l'étendue de la matérialisation du principe du développement durable, le vecteur central de notre structure constitutionnelle de protection de l'environnement.

Dans ce contexte, il semble nécessaire revisiter notre systématique de protection et de contrôle de l'environnement, afin de proposer l'utilisation de mécanismes qui apportent une vision large, générale et non pas ponctuelle de nos activités économiques qui 
interagissent avec l'environnement, de façon à ce que nous puissions compléter les mécanismes établis par l'application des principes de la prévention et du polluer-payeur avec des mesures supplémentaires d'un profil d'intégration, en privilégiant des politiques publiques et en cherchant la matérialisation du principe du développement durable.

À notre avis, cette mission est possible par l'utilisation des impôts en tant qu'un élément capable d'induire des conduites et des actions, leur application n'étant plus ponctuelle et par le mécanisme de l'incitation fiscale, mais par la création d'environnements, aux secteurs de l'économie, où l'adoption de certaines technologies, le mode de production ou le traitement des risques environnementaux soient induits et choisis naturellement par le capital d'investissement. Ainsi, les outils déjà existants, de contrôle, de prévention et de répression sont complétés par l'adoption d'un système d'induction d'ordre général et non simplement ponctuel.

La façon d'établir les mécanismes appropriés à cette mission, à notre avis, est celle de l'examen des politiques publiques concernant l'environnement vis-à-vis d'autres politiques publiques et également vis-à-vis d'autres politiques publiques concernant l'environnement.

Notre proposition est celle d'utiliser des mécanismes fiscaux pour la matérialisation de cet objectif, en choisissant la CIDE comme un outil approprié. L'exemple que nous avons élu a été celui de la Politique nationale sur le changement du climat, à être prise en compte vis-à-vis de la Politique nationale d'énergie et de la Politique forestière.

Mots-clés: développement durable, impôts concernant l'environnement. 


\section{SUMÁRIO}

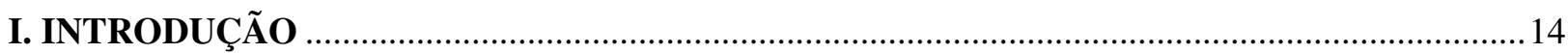

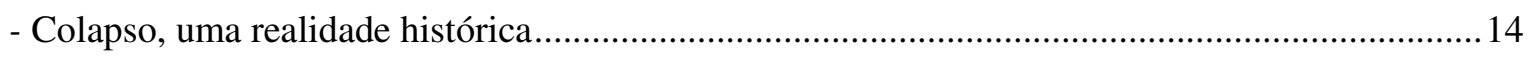

- Os povos que sucumbiram, e as razões que levaram a tanto - a variável climática como - -

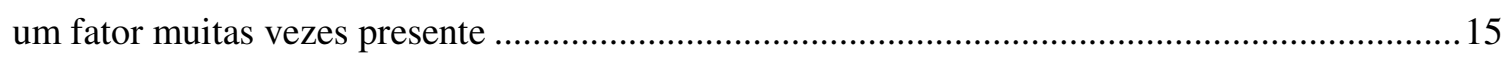

- O Estado organizado, as relações de comércio, e a ampliação dos riscos ....................................... 16

\section{A EVOLUÇÃO DA CONSCIÊNCIA AMBIENTAL E SEUS EFEITOS NO BRASIL ...............21}

(1) a evolução do sistema - construção da consciência e do marco legal e constitucional....................21

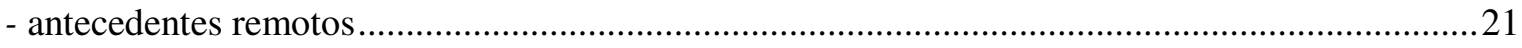

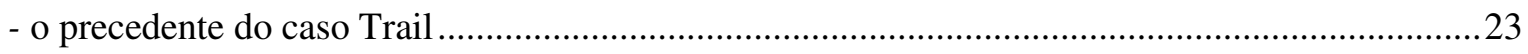

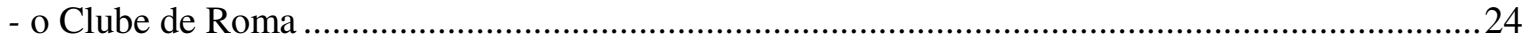

- o Conselho Econômico e Social das Nações Unidas - ECOSOC ..................................................2

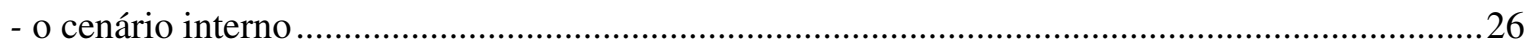

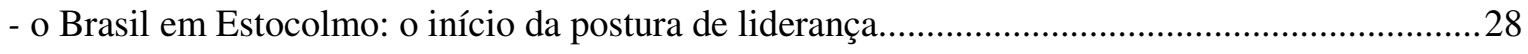

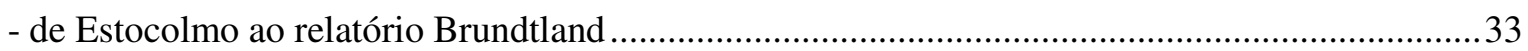

- os efeitos de Estocolmo sobre o Brasil - o marco legal interno e a consagração de uma

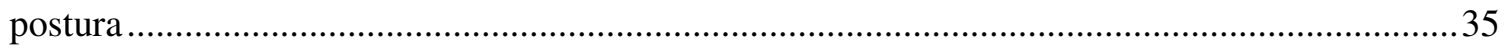

- o marco constitucional (e o destaque ao tema objeto deste trabalho).............................................39

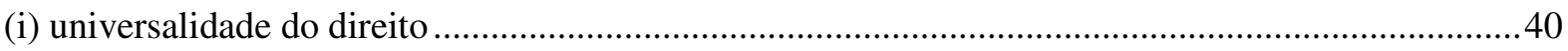

(ii) Bem de uso comum e o desenvolvimento da noção de bem ambiental ..........................................40

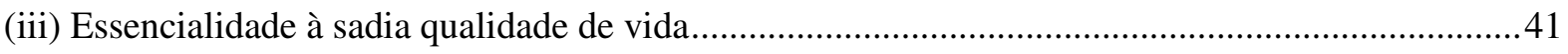

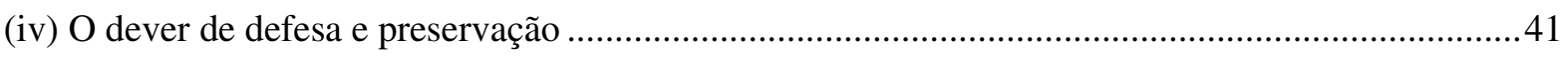

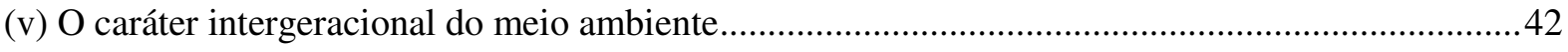

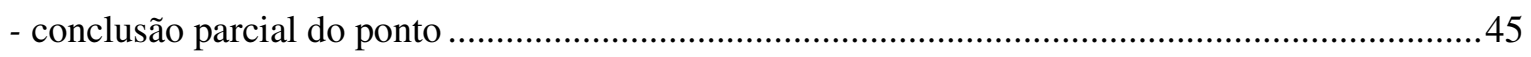

(2) exame crítico: os eventos históricos, os 30 anos de aplicação e a constatação da saturação do

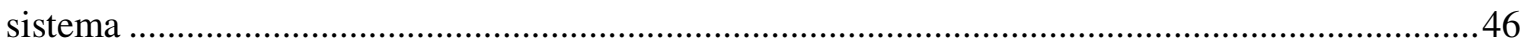

- Da entrada em vigor da Lei $n^{\circ}$. 6.938/81 até o estabelecimento da Lei $n^{\circ}$. 7.347, de 24.7.1985.

- De julho de 1985 até a inserção do $\S 6^{\circ}$ ao artigo $5^{\circ}$ da Lei $n^{\circ} .7 .347 / 85$, ocorrido em 1990: o Termo de Ajustamento de Conduta - TAC e o resgate do passivo ambiental . .50

- Do Termo de Ajustamento de Conduta - TAC à responsabilidade penal, vinda efetivamente

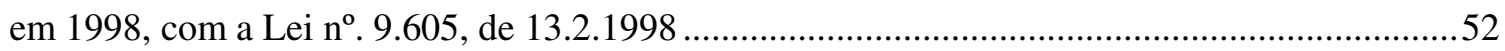

- a responsabilidade penal e seus efeitos sobre a questão ambiental ...............................................53

- Conclusão parcial do ponto: o sistema saturado, e as iniciativas recentes de complementação - postura diante da questão

- O século XXI e a superação dos parâmetros legais de comando e controle como paradigma único ao trato da questão ambiental, e a inserção da questão da sustentabilidade 
- a questão do clima - o atendimento ao propósito constitucional e a internalização dos preceitos firmados no plano internacional...

(3) conclusão final do ponto - o ambiente para inovações e os fundamentos gerais da proposta

\section{A POSTURA BRASILEIRA NO ÂMBITO DA CONVENÇÃO-QUADRO SOBRE A MUDANÇA DO CLIMA E A QUESTÃO NO PLANO INTERNO.}

(1) a Convenção-Quadro, o Protocolo de Quioto, a postura brasileira nas negociações e a peculiar condição nacional diante das emissões de GEE.

(2) a legislação interna e propostas em trâmite.

(i) a Lei no . 12.187/2009 - A Política Nacional sobre Mudança do Clima...........................................85

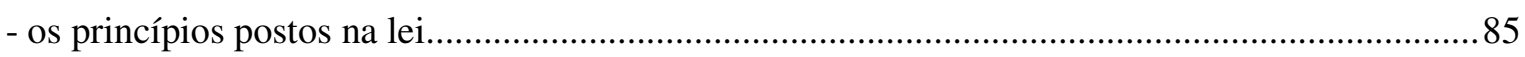

- as ações para implementação da Política Nacional sobre Mudança do Clima .................................86

- as diretrizes para a implementação da Política Nacional sobre Mudança do Clima .......................87

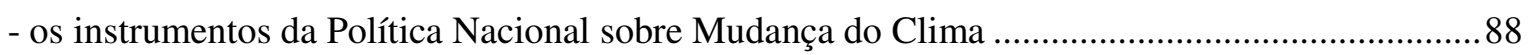

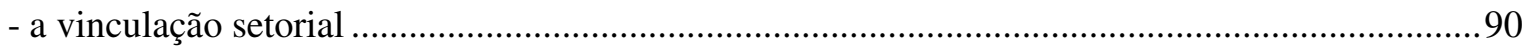

- o veto aos artigos $4^{\circ}$, III, e 10, e a contraposição ao artigo 11 da Lei - efeitos e crítica .................91

- por fim, a meta assumida e sua natureza ...................................................................................... 98

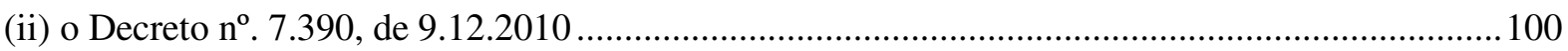

- Florestas - a legislação e as propostas em trâmite, de interface direta ou indireta .......................103

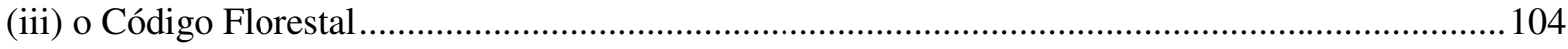

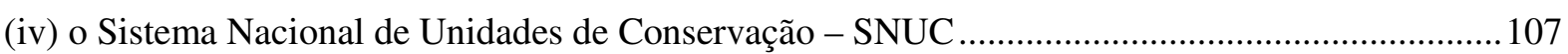

(v) o Projeto de Lei $n^{\circ}$. 195/11, que regulamenta o mercado de REDD+ ..........................................109

(vi) o Projeto de Lei $n^{\circ}$. 309/2010, que disciplina o pagamento por serviços ambientais.....................110

- o setor de energia

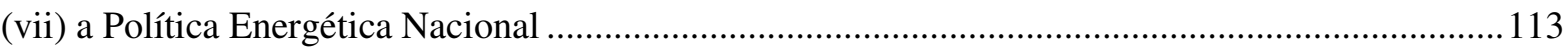

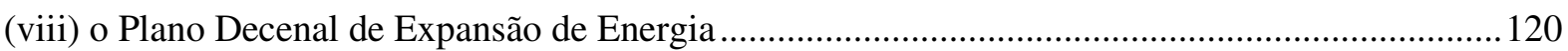

(ix) o modelo atual, sua estrutura e o efeito para as políticas públicas transversais ...........................123

- considerações finais do ponto..

IV. A IMPLEMENTAÇÃO DO ARTIGO $6^{\circ}$, VI, DA LEI No. 12.187/2009: A INTERVENÇÃO QUALITATIVA DO ESTADO SOBRE A ORDEM ECONÔMICA, OS MECANISMOS TRIBUTÁRIOS DISPONÍVEIS, E O ENTENDIMENTO QUANTO AO CAMINHO A TRILHAR

(1) o exame já feito e as constatações e premissas a adotar para este ponto do trabalho.

(2) A intervenção qualitativa do Estado sobre a ordem econômica - a base teórica para essa abordagem, no âmbito da questão ambiental - a inserção da questão ambiental no campo econômico

(3) O Direito Ambiental e o Direito Tributário - a materialização da intervenção qualitativa na ordem econômica.

(3.a) o conceito de "justo" no contexto deste trabalho, para fins do exame dos tributos em espécie aplicáveis às hipóteses geral, do setor de energia e do setor de florestas. 
(3.b) A finalidade dos tributos como marco identificador ................................................................ 141

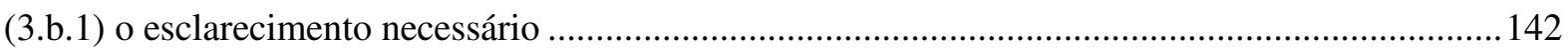

(3.b.2) a função extrafiscal dos tributos - o cerne do exame proposto ………...................................146

(3.b.3) alguns comentários salutares à consideração do uso dos tributos de índole extrafiscal superação de potenciais questões e dúvidas para o exame dos casos concretos que se passará a realizar mais adiante.

(3.b.iv) o princípio informador da aplicação dos tributos de índole extrafiscal no atendimento aos preceitos constitucionais relativos à ordem econômica e ao meio ambiente

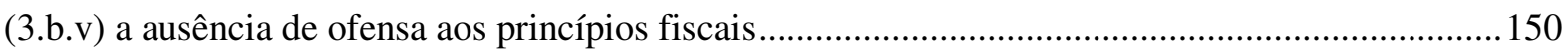

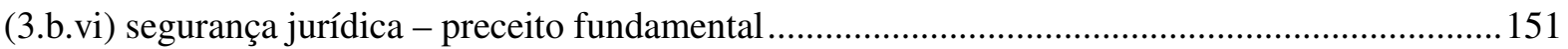

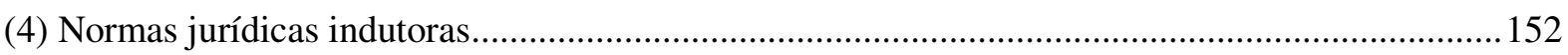

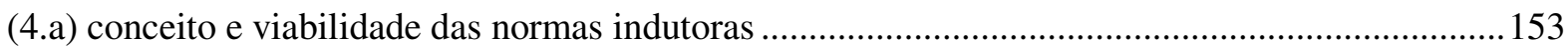

(4.b) indução compreendida como elemento de implementação de objetivos amplos, de políticas

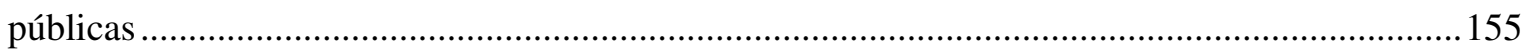

(4.c.) Indução compreendida como instrumento de busca do "justo": Steuerunginstrument ..............156

(4.d) a questão do princípio da capacidade contributiva e a viabilidade da tese defendida.................159

(5) as espécies de tributo e a adequação à conjugação das competências ambientais e fiscais ..........161

(6) O caso da Política Nacional sobre Mudança do Clima - tributos e as espécies adequadas - a proposta..

(6.a) A integração, pela transversalidade, entre a Política Nacional sobre Mudança do Clima e a política energética

(6.b) A integração, pela transversalidade, entre a Política Nacional sobre Mudança do Clima e a política florestal 


\section{INTRODUÇÃO}

\section{- Colapso, uma realidade histórica}

Ao longo da História, civilizações surgiram, tiveram seu apogeu, e depois desapareceram, foram varridas do planeta, por conta da relação que mantiveram com o ambiente em que se inseriam.

Em Colapso ${ }^{1}$, Jared Diamond ${ }^{2}$ demonstra que, ao longo do processo civilizatório, vários povos que se destacaram pela organização e avanço sucumbiram, em sua maioria, diante de fatores internos, tais como a superpopulação e os conflitos pelo poder, e fatores externos, como as intempéries e o clima.

Dos Maias aos habitantes da Ilha de Páscoa, passando por várias outras civilizações ou grupos, o ser humano sempre conviveu e sofreu diante do risco trazido à sua própria sobrevivência pelo "desenvolvimento" das comunidades em torno das quais se organizou.

Em comum a todos esses exemplos, mesmo aqueles que Jared Diamond destaca por terem encontrado resultado final de sucesso, verifica-se o constante conflito e risco decorrente da absorção indiscriminada de recursos naturais.

Com efeito, na História do Homem, verifica-se que o processo civilizatório apoiouse, até muito recentemente, na equivocada premissa da infinitude dos recursos naturais, que suportou, ao longo desse período, a adoção de uma postura utilitarista ${ }^{3}$ na relação homem $\mathrm{X}$ meio ambiente. O próprio Jared Diamond ${ }^{4}$ destaca essa noção equivocada como fonte de um dos problemas que levaram ao fim de civilizações e sociedades ao longo da História: "Qualquer povo pode cair na armadilha de sobreexplorar recursos ambientais (...) os recursos a princípio pareciam inesgotavelmente abundantes”.

\footnotetext{
${ }^{1}$ DIAMOND, Jared. Colapso: como as sociedades escolhem o fracasso ou o sucesso. 5. ed. Rio de Janeiro: Record, 2007.

${ }^{2}$ Autor também de Armas, Germes e Aço, obra vencedora do Prêmio Pulitzer.

${ }^{3}$ Não se pode aqui confundir o conceito com o de ética utilitarista, de Mill. O que se diz, da relação Homem $\mathrm{X}$ meio ambiente, é que a absorção dos recursos naturais se dava de forma meramente utilitarista, ou seja, utilizava-se os recursos naturais em favor do interesse da produção, sem qualquer preocupação, em razão da equivocada noção de infinitude.

${ }^{4}$ DIAMOND, Jared. op. cit., p. 25.
} 
Sob esse entendimento é que, ao longo do processo civilizatório, verificaram-se as situações limite nas quais povos altamente desenvolvidos, em suas épocas, sucumbiram diante das intempéries e da escassez de recursos que esses mesmos povos criaram.

\section{- Os povos que sucumbiram, e as razões que levaram a tanto - a variável climática como um fator muitas vezes presente}

Jared Diamond visita vários exemplos de povos que, a despeito de seu avançado desenvolvimento diante de seus contemporâneos, sucumbiram e desapareceram, simplesmente, ou foram forçados a recriar sua forma de viver. Esclarece Diamond que esses processos, pelos quais "as sociedades do passado minaram a si mesmas danificando o meio ambiente dividem-se em oito categorias, cuja importância relativa difere de caso para caso: desmatamento e destruição do hábitat, problemas com o solo (erosão, salinização e perda de fertilidade), problemas com o controle da água, sobrecaça, sobrepesca, efeitos da introdução de outras espécies sobre as espécies nativas e aumento per capita do impacto do crescimento demográfico",5.

Em vários dos exemplos citados por Diamond, o clima desempenhou importante ou fundamental papel na derrocada de sociedades que, até pouco antes, destacavam-se diante das outras sociedades a si contemporâneas pelo desenvolvimento que apresentavam. Os nórdicos que colonizaram a Groenlândia são um dos exemplos que Diamond cita em sua obra: após desmatar áreas relevantes, premidos pelo clima (e variáveis outras), esses colonizadores da Groenlândia viram sua organização social avançada ceder e sucumbir.

Em recente entrevista à Revista VEJA ${ }^{6}$, Ian Morris, autor de Why the West Rules for $n o w^{7}$, comenta acerca do que chama de "cinco cavaleiros do Apocalipse" (migração, doença, fome, falência do estado e mudança climática), para dizer que os "colapsos" (episódios em que determinadas sociedades sucumbem) ocorrem quando esses “cavaleiros" apresentam-se em conjunto. Morris cita os casos do Império Romano, da Dinastia Han, na China, e da dizimação dos nativos da América com a colonização europeia, para destacar que, em regra, um dos "cavaleiros" deflagra o processo de

\footnotetext{
${ }^{5}$ DIAMOND, Jared. op. cit., p. 18-19.

${ }^{6}$ VEJA, São Paulo, ano 44, n. 49, ed. 07 dez. 2011. p. 21.

${ }^{7}$ MORRIS, Ian. Why the west rules: for now. Londres: Profile Books, 2010.
} 
“colapso”. Para o colapso que poderá eventualmente ocorrer no século XXI, Morris indica a mudança climática como fator deflagrador do processo.

Do exame desses exemplos, ocorridos ao longo da História, verifica-se que, seja como elemento importante, seja como elemento preponderante e determinante, a questão do clima exerceu, sempre, forte influência para a ocorrência do período de declínio e desintegração dos povos que, diante de um aparente desenvolvimento superior aos demais, encontravam-se, na realidade, a caminho de sua autoinviabilização e destruição.

\section{- O Estado organizado, as relações de comércio, e a ampliação dos riscos}

Todos os exemplos de ocaso de civilizações e povos acima identificados tiveram lugar no período pré-organização dos povos em Estados voltados à relação inter-Estatal, calcada no comércio. Até que se chegasse a essa fase, as civilizações ou Estado isolados enfrentavam situações internas, que dificilmente trariam efeitos e impactos a outros grupos. Não se verificava uma inter-relação que demandasse a adoção de valores e regras comuns a vários Estados, como forma de se evitar o risco comum. Com o desenvolvimento do comércio e a aproximação entre os Estados é que se chegou a um ponto em que o risco, que antes era pontual a esta ou aquela civilização ou povo, passou a ser de todos, sem conhecer fronteiras ou costumes, seja no modo de produção capitalista, seja no modo de produção comunista.

Fundamental, neste ponto, fazer um breve escorço histórico, sob a perspectiva do ambientalismo. Até o período da Segunda Grande Guerra (1939-1945), os exemplos de preocupação de ordem ambiental eram, sempre, isolados, no contexto global, e praticamente inexistentes, no contexto nacional. De toda sorte, no plano interno, não se verificava a existência de estrutura legal voltada à proteção do meio ambiente como bem sob tutela do Estado.

Com o fim da Segunda Grande Guerra, e a polarização do mundo entre os dois sistemas distintos de produção (e Era dos Extremos, de $\operatorname{Hobsbawn}^{8}$ ), não se verificava espaço para que a variável ambiental fosse inserida em um ou em outro sistema. O período da Guerra Fria, acima de tudo, representou cenário no qual desenvolvimento mais agudo das regras de controle e proteção ambiental encontraria obstáculo não apenas na

\footnotetext{
${ }^{8}$ HOBSBAWN, Eric. Era dos extremos: o breve século XX - 1914-1991. 2. ed. 9. reimpr. São Paulo: Compahia das Letras, 1997.
} 
necessidade de crescimento social e econômico, como também na vontade, dos Estados líderes do conflito (Estados Unidos da América e União das Repúblicas Socialistas Soviéticas), de manter seu crescimento armamentista. A escalada armamentista, de fato, representava forte obstáculo a um maior avanço dos mecanismos de controle e proteção ambiental.

A única diferença na abordagem da questão ambiental, pelos Estados capitalistas e comunistas, residia na indicação da propriedade sobre os recursos naturais e o potencial de geração de riquezas que representavam, ainda sob a premissa de sua infinitude: no regime capitalista, admitia-se a privatização dos recursos naturais, para seu uso na cadeia produtiva, ali entendido como um elemento de agregação de riquezas, sem custo de aquisição. Já no regime comunista, os recursos naturais, igualmente sob apropriação para inserção na cadeia de produção econômica, eram havidos como de propriedade do Estado.

Não obstante, e conforme verificaremos mais além neste texto, deu-se a partir já da década de 1960 (ou seja, ainda no auge da Guerra Fria) o desenvolvimento, em paralelo às questões do conflito polarizado, de uma consciência da necessidade de controle e proteção ambiental, precursora do surgimento, a partir da década de 1970, de novos valores, princípios, sistemas e regras com tal intuito.

Esses valores, princípios, sistemas e regras encontraram campo fértil para seu desenvolvimento na nova realidade mundial, vivida a partir dos anos 1990, em que a globalização da economia impôs aos Estados integrados nesse sistema de comércio amplo a criação de espaço para a inserção da variável ambiental, de início por meio de regras de controle sobre a atividade produtiva, por parte do Estado, e, depois, como ferramenta de diferenciação de qualidade de produtos no plano dos negócios.

Nesse contexto, tomados os exemplos de civilizações e povos que sucumbiram diante de questões de caráter interno e externo, no período prévio ao estabelecimento das relações de interdependência comercial e - mais recentemente - política (como é o caso da Comunidade Europeia), e observadas as condições dos Estados atuais, será forçoso concluir que os riscos que antes assombravam essas civilizações e povos ensimesmados necessariamente continuam a existir, gerando riscos, atualmente, a todos os Estados integrados na economia globalizada.

Por consequência, conclui-se que os riscos trazidos pelas variáveis internas e externas àquele tempo verificadas, caso venham se materializar agora, terão como resultado 
consequências de dimensões infinitamente maiores, sob as quais poderá sucumbir não apenas uma civilização ou povo, mas outros e até mesmo todos os Estados globalizados.

Some-se o fato de que, com o desenvolvimento tecnológico e das relações comerciais, e com o desenvolvimento industrial, aos elementos de risco à sobrevivência de uma sociedade ou povo, a que se referia Diamond ao analisar os exemplos históricos conhecidos, acrescentam-se agora outros fatores de risco. Nas palavras do próprio Diamond, são quatro as fontes de risco hoje enfrentadas, adicionais às oitos vertentes que, ao longo da História, afetaram povos e sociedades: "mudanças climáticas provocadas pelo homem, acúmulo de produtos químicos tóxicos no ambiente, carência de energia e utilização total da capacidade fotossintética do planeta”.

Dentre esses riscos, assume especial relevância, em nossos tempos, a questão do clima. Causa e consequência concomitantemente, a variação climática exerce pressão sobre o sistema, ao mesmo tempo em que é por ele diretamente influenciada, impondo, pois, absorção, pelos Estados, da consideração de suas causas e efeitos na revisão e formulação de políticas públicas.

Tal fenômeno, o da consideração da variável climática na formulação de políticas públicas, é de todo recente. Em que pese a discussão dos efeitos da mudança do clima, no meio científico, remonte ao início do século XX, o fato é que, até recentemente, tal debate não integrava a agenda das relações internacionais, no seu plano político.

Felizmente, a inserção da questão climática em nossa pauta de debates encontrou já território fértil, uma vez que nossa consciência ambiental, hoje bastante desenvolvida e disseminada, permitiu que o debate se desse de forma ampla. A necessidade de atuação efetiva da comunidade global, em favor do combate às emissões de Gases de Efeito Estufa - GEE e à mitigação de seus efeitos, justificam o tema aqui proposto.

Isto porque, no campo das relações internacionais, assumiu especial relevância a participação brasileira diante da inserção das temáticas do clima e da biodiversidade no âmbito das assembleias da Organização das Nações Unidas - ONU.

Paralelamente, no plano do desenvolvimento de nossa estrutura nacional de proteção ambiental, vemo-nos diante de um sistema saturado, calcado no binômio comando-controle, e que já há alguns anos busca a criação e desenvolvimento de novos paradigmas e ferramentas. Nesse contexto é que se insere a implementação da Política 
Nacional sobre Mudança do Clima, estabelecida pela Lei nº 12.187, de 29.12.2009.

O estudo que aqui se desenvolverá toca a este tema: vinda a Política Nacional sobre Mudança do Clima, e trazido em sua regulamentação parcial, em 9.12.2010, o Decreto n $^{\circ}$ 7.390 (Regulamenta os arts. 6ㅁ, 11 e 12 da Lei $n^{0}$ 12.187, de 29 de dezembro de 2009, que institui a Política Nacional sobre Mudança do Clima - PNMC, e dá outras providências), o que se pretende é apresentar propostas para a implementação de mecanismos aptos à viabilização do alcance dos objetivos, no plano nacional, do combate às emissões de Gases de Efeito Estufa - GEE e mitigação de seus efeitos.

Para tal fim, adotar-se-á como ferramenta considerada adequada a adoção de tributos de natureza indutora, a teor da faculdade/orientação inserta no texto constitucional (artigo 170, VI, da CF, na forma como decorrente da Emenda Constitucional $\mathrm{n}^{\circ}$ 42, de 19.12.2003 (defesa do meio ambiente, inclusive mediante tratamento diferenciado conforme o impacto ambiental dos produtos e serviços e de seus processos de elaboração e prestação) e como expressamente indicado no artigo $6^{\circ}$, VI, da Lei $\mathrm{n}^{\mathrm{o}}$ 12.187/2009 (as medidas fiscais e tributárias destinadas a estimular a redução das emissões e remoção de gases de efeito estufa, incluindo alíquotas diferenciadas, isenções, compensações e incentivos, a serem estabelecidos em lei específica).

Para se trilhar o caminho de demonstração do acerto dessa proposta, adotar-se-á como metodologia de análise de nosso sistema o método histórico, ou seja, examinar-se-á o desenvolvimento de tal sistema, ao longo dos últimos trinta anos (adotando-se como marco inicial a Lei $\mathrm{n}^{\mathrm{o}}$ 6.938, de 31.8.1981, por meio da qual se aprovou a Política Nacional do Meio Ambiente), expondo-se suas virtudes e fraquezas, de forma a se poder, ao cabo de tal análise, indicar as ferramentas adequadas à sua complementação e efetivação de seus objetivos. Tal análise, portanto, pretende ser conceitual.

Finda esta primeira etapa, tomar-se-á o quanto estabelecido pelo inciso VI do artigo $6^{\circ}$ da Lei $n^{0} 12.187 / 2009$ para se propor, no âmbito do quanto ali determinado, ferramentas adequadas à sua materialização (ou seja, as medidas fiscais e tributárias destinadas a estimular a redução das emissões e remoção de gases de efeito estufa), observados dois ambientes específicos: florestas e energia (conforme destacados no artigo 11 da Lei $n^{\circ}$ 12.187/2009 e tratados pelo Decreto $\mathrm{n}^{\mathrm{o}} 7.390 / 2010$ ). 
Essa análise divide-se em tópicos que, em síntese, trazem os seguintes termos: no capítulo seguinte a este demonstrar-se-á que, tomada a evolução da consciência ambiental no mundo e no Brasil, a conclusão a que se chega é a de que o estabelecimento de nosso sistema de proteção ambiental, fundado no mecanismo do comando e controle, gerou uma estrutura que, passados trinta anos, mostra-se esgotada em sua capacidade de alcançar o objetivo da harmonização entre proteção ambiental e desenvolvimento de atividades econômicas. Fundado em quase sua totalidade na aplicação dos princípios do poluidorpagador e da reparação, nosso sistema reclama, veremos, novas saídas, para não nos vermos estagnados.

No capítulo seguinte, atinente à postura brasileira diante do tema da mudança do clima, constataremos que, tanto no âmbito internacional quanto no campo interno, escolhemos liderar debates e assumir posições de vanguarda, dentre as quais destaca-se a assunção de metas internas de redução de emissão de Gases de Efeito Estufa às quais não estamos vinculados pelos instrumentos internacionais. Notaremos ainda que nossas políticas públicas florestal e energética tratam dos temas objeto de sua consideração sem ter em conta a questão do clima e de nossas metas de redução de emissão de Gases de Efeito Estufa.

Veremos então, no Capítulo IV, que a integração, pelo método da transversalidade, entre essas três ordens de políticas públicas, permitirá alcançar o objetivo da complementação do sistema que de início verificamos estar saturado, dando-se tal resultado por meio da adoção do princípio da sustentabilidade em substituição ao princípio do poluidor-pagador como elemento de orientação dessa integração. Identificaremos então que o veículo adequado para realização dessa integração transversal é o do uso de tributos como ferramenta de intervenção qualitativa do Estado sobre a economia, obtendo-se como resultado a indução a posturas e condutas sustentáveis por parte do mercado.

Ainda no Capítulo IV, verificaremos ser a Contribuição de Intervenção sobre o Domínio Econômico - CIDE a espécie tributária adequada ao propósito buscado neste estudo, da integração transversal de políticas públicas a que nos referimos, para então concluirmos, no Capítulo V, pela possibilidade de sucesso do sistema proposto.

Todo o trabalho aqui realizado busca contribuir para a viabilização de uma transição, por meio da qual se poderá deixar de estabelecer normas de cunho tributário para implementação do princípio do poluidor-pagador, passando-se a instituir tais instrumentos sob o signo do princípio da sustentabilidade. 


\section{A EVOLUÇÃO DA CONSCIÊNCIA AMBIENTAL E SEUS EFEITOS NO BRASIL}

\section{(1) a evolução do sistema - construção da consciência e do marco legal e constitucional}

- antecedentes remotos

A referência histórica primeira à questão da gestão ambiental remonta à Arca de Noé. Consta da narrativa de tal passagem bíblica menção aos resíduos gerados pelos animais. E, no mesmo relato, vê-se já os extremos naturais como vetor da imposição, ao Homem, da adoção de medidas extraordinárias para a preservação da vida.

A natureza, desde tais tempos e até o século XVII, é tratada como ente integrante do mundo divino. Assim, porque sujeita aos desígnios divinos, não encontra tratamento e apropriação no campo normativo senão nas normas emanadas pela realeza, que detém tal posição e poder por representar a expressão personificada da vontade divina.

Nesse contexto é que, tomando-se o espaço brasileiro, encontraremos exemplos normativos de restrição à exploração do Pau-Brasil, por exemplo, por força de determinação da Coroa. Tais normas, no entanto, não visavam à proteção do bem natural em si, mas apenas e tão somente do valor econômico por ele representado. De fato, exclusivamente porque altamente valorizado do ponto de vista econômico, é que o PauBrasil mereceu restrição legal à sua exploração pelo comum dos homens. À Coroa se reservava tal direito de exploração que, como é notório, se dava - como de fato durante longo período se deu - de forma predatória, sem qualquer atenção ou preocupação para com a necessidade de preservação e perenização da espécie sob exploração.

Ainda sob a visão estritamente econômica do uso dos recursos naturais, o homem passa no entanto a ver a natureza não mais como ente sujeito aos desígnios divinos, 
quando, em 1869 (conforme afirma Maria Bernadete Ribas Lange ${ }^{9}$ ) Ernst Haeckel introduz o termo ecologia, adotando o entendimento segundo o qual a natureza passa a ser considerada elemento sujeito à ciência, e não mais um elemento da esfera divina. Reduzse, pois, a natureza, nessa fase, a um elemento de equações que buscam o desenvolvimento econômico.

Sob essa perspectiva, acirra-se o entendimento de que a natureza prestar-se-ia a servir ao propósito de desenvolvimento da sociedade e suas atividades, não se tendo notícia, ainda, de movimentos ou ideais de preservação para a perenização de quaisquer dos recursos naturais. A sociedade de troca, o modus vivendi do homem dito moderno, dependente da apropriação indiscriminada dos recursos naturais para o que se denominava (e, em certa medida, ainda se denomina) de desenvolvimento, não via e não podia ver na natureza finita dos recursos naturais obstáculo ao espetáculo do desenvolvimento. $\mathrm{O}$ homem parecia não se dar conta de que não são infinitos os recursos naturais.

Longo período decorre até que comecem a surgir, com força bastante para serem ouvidas, as vozes de alerta para o fato de que caminhava o ser humano para a autodestruição, seja porque finitos os recursos naturais, seja ainda porque demasiado acelerada a sua apropriação, ou ainda porque o modo de produção descontrolado gerava níveis tais de poluição que, a médio prazo, ver-se-ia o homem incapaz de suportar o ambiente por ele mesmo criado.

\section{- o precedente do caso Trail}

Alguns exemplos de discussão da questão ambiental, já sob olhar que desbordava de sua consideração a partir do aspecto de seus efeitos no espaço e alcance nacional, surgem antes da década de 60, na qual, conforme se afirmará adiante, é que se tem a efetiva adoção da temática ambiental como item de preocupação internacional sob o enfoque da preservação. Desses esparsos exemplos, anteriores à década de 60, merece especial destaque o Caso da Fundição Trail, acerca do qual (e do contexto em que se inseriu) se colhe aqui os comentários de Guido Soares:

\footnotetext{
${ }^{9}$ LANGE, Maria Bernadete Ribas. A conservação da natureza: conceitos e breve histórico. VEIGA RIOS, Aurélio Virgílio; HUGUENEY IRIGARAY, Carlos Teodoro (Orgs.). O direito e o desenvolvimento sustentável. São Paulo: Peirópolis, 2005. p. 13.
} 
Uma das primeiras manifestações do Direito Internacional do Meio Ambiente deu-se no entre-guerras, com a realização de uma arbitragem entre os EUA e o Canadá, a respeito de poluição atmosférica que, gerada por uma fábrica localizada em território canadense, produzia seus efeitos deletérios em território do Estado de Washington, nos EUA: tratou-se do Caso da Fundição Trail, julgado definitivamente por um tribunal ad hoc em 1941, empresa aquela responsável por danos causados a cidadãos norte-americanos, cujas reivindicações não satisfeitas pelos empresários canadenses (dos quais se destacavam não só os pedidos de indenizações, parcialmente satisfeitos perante tribunais canadenses ou norteamericanos, mas cujas fontes de danos persistiam, como também, e principalmente, a cessação das atividades poluidoras), acabaram por motivar os EUA a tomarem como seus aqueles direitos (exercício da proteção diplomática) e a litigarem, em nome próprio, perante o Canadá, as medidas cabíveis. Dos resultados daquela arbitragem, resultou norma internacional que seria, enfim, escrita nas duas grandes Declarações, de Estocolmo, em 1972 e do Rio, em 1992. Conforme a versão constante da Declaração do Rio, trata-se do Princípio 2, assim redigido:

"Os Estados, de conformidade com a Carta das Nações Unidas e com os princípios de Direito Internacional, têm o direito soberano de explorar seus próprios recursos segundo suas próprias políticas de meio ambiente e desenvolvimento, e a responsabilidade de assegurar que atividades sob sua jurisdição ou controle não causem danos ao meio ambiente de outros Estados ou de áreas além dos limites da jurisdição nacional." ${ }^{10}$

Veja-se, aqui, o perfil da consideração do aspecto ambiental àquele tempo: o trato da questão ambiental submetia-se à vontade soberana do Estado, preservado o direito, a outros Estados, de verem ressarcidos os eventuais danos que viessem a sofrer por força das externalidades $^{11}$ negativas decorrentes das atividades desenvolvidas por outros Estados. Por outras palavras, não havia, ali, uma abordagem de ordem internacional para a questão, sob a qual se estipulasse limites comuns a Estados distintos, como forma de absorção plena da questão, com sua posterior internalização. Ao contrário, a cada Estado era dado estabelecer suas próprias regras, como se a questão ambiental tocasse a interesses estritamente nacionais, sempre vinculados ao interesse do crescimento econômico e social.

\footnotetext{
${ }^{10}$ SOARES, Guido Fernando Silva. Curso de direito internacional público. São Paulo: Atlas, 2002. v. 1, p. 425-426.

${ }^{11}$ Nos dizeres de Ana Nusdeo, citando Nick Handley et al., "Externalidades são custos ou benefícios cujos ônus ou vantagens recaem sobre terceiros ao invés daqueles que participaram de uma transação de mercado. Ocorrem, assim, quando 'as ações de uma pessoa afetam outras que não recebam compensação pelo dano causado nem pagam pelos benefícios gerados'”
} 


\section{- o Clube de Roma}

As vozes defensoras de uma visão mais abrangente, de natureza plurinacional para a questão do meio ambiente, ganham corpo de início no cenário europeu, e é lá que se tem o primeiro marco internacional de manifestação pela necessidade de revisão da postura do homem, de forma global, diante da natureza.

Toma-se aqui o evento conhecido como Clube de Roma. Dá-se tal denominação a encontro havido em 1968, em Roma, entre cerca de 30 estudiosos da questão ambiental.

Tal encontro deu-se já por conta da sedimentação, na Europa, da noção da necessidade de adequação do modus vivendi do Homem a um modelo de exploração ambiental que não levasse ao esgotamento dos recursos naturais e da capacidade de suporte do Planeta, bem como da necessidade de estabelecimento de regras internacionais, comuns aos Estados, no tocante à padronização de condutas diante dos riscos ambientais.

O que se vê já àquele tempo na Europa é, portanto, a revisão do paradigma do desenvolvimento econômico como vetor primeiro, principal, do alcance da adequada qualidade de vida sempre almejada e buscada pelo Homem, ainda que em detrimento da qualidade ambiental.

As conclusões do encontro realizado, por impulso do Massachussets Institute of Technology -MIT, foram registradas na obra de título "Os Limites do Crescimento". Em apertada síntese, tal trabalho concluiu pela inviabilidade da manutenção do ritmo de crescimento então verificado nas atividades antrópicas no que toca ao uso dos recursos naturais, sob pena de esgotamento desses recursos a médio prazo. Por conta dessa constatação, sugeriram os estudiosos o congelamento, nos níveis então observados, do acesso aos recursos naturais pelo Homem, de forma a se evitar o esgotamento previsto. Tudo sob consenso e participação internacional, para que tivesse eficácia a medida.

Porque vivia o mundo violenta dicotomia entre Países Desenvolvidos e Países Subdesenvolvidos, tal trabalho foi recebido com fortes críticas. A interpretação que se deu à proposta formulada não poderia ser mais negativa. Entenderam os Países menos desenvolvidos que o intuito do quanto posto na obra em questão seria o de restringir-lhes o desenvolvimento econômico, estabelecendo-se um sistema de manutenção do status quo por força do qual os Países Desenvolvidos seguiriam crescendo, enquanto aos Países menos desenvolvidos restaria sucumbir diante da escassez de recursos para fomentar seu crescimento econômico. 
Acalorado debate se seguiu nos meios internacionais. Para o bem ou para o mal, o fato é que o Clube de Roma pode ser considerado um embrião da Conferência Mundial Sobre o Meio Ambiente Humano, realizada em Estocolmo, em 1972. Édis Milaré trata de indicar o cenário que se vivia então na comunidade internacional, ao afirmar que

No final da década de 60, preocupada com o crescimento econômico e o processo de industrialização predatória, a Suécia propôs à ONU a realização de uma conferência internacional para discutir os principais problemas ambientais que já alcançavam uma dimensão global, relacionando-os a questões socioeconômicas, em especial à pressão do crescimento demográfico sobre os recursos naturais nos países mais pobres $^{12}$.

\section{- o Conselho Econômico e Social das Nações Unidas - ECOSOC}

De acordo com o comentário mais detalhado de Wagner Costa Ribeiro,

Foi a partir da indicação do Conselho Econômico e Social das Nações Unidas ou United Nations Economic and Social Council (ECOSOC), em julho de 1968, que surgiu a idéia de organizar-se um encontro de países para criar formas de controlar a poluição do ar e a chuva ácida, dois dos problemas ambientais que mais inquietavam a população dos países centrais. Enviada à Assembléia Geral da ONU, a indicação foi aprovada em dezembro daquele ano. ${ }^{13}$

Nesse contexto, importante verificar que a questão ambiental efetivamente deveria ter a Europa por ponto de partida para o fervilhar de ideias. Recortada por países nem sempre de grandes dimensões, e para além de representar cultura mais avançada dos pontos de vista legal, social e tecnológico, a Europa representa ainda, por suas características geopolíticas, um celeiro sem par para o surgimento de conflitos de natureza fronteiriça, bem como para o desenvolvimento de regras de Direito Internacional. Não apenas o fenômeno da chuva ácida demonstra esse estado de coisas. O acidente verificado em unidade fabril do grupo Sandoz, em 1986, bem dá a dimensão dessa condição: ocorrido na Basileia, o acidente gerou o carreamento de contaminantes para o Rio Reno, atingindo 5 diferentes nações, o que o tornou um acidente de grandes proporções internacionais.

\footnotetext{
${ }^{12}$ MILARÉ, Edis. Direito do ambiente. 4. ed. São Paulo: Ed. Revista dos Tribunais, 2005. p. 140.

${ }^{13}$ RIBEIRO, Wagner Costa. A ordem ambiental internacional. São Paulo: Ed. Contexto, 2001. p. 73.
} 
Esse o vetor, o motor de arranque para a consideração das questões ambientais em tal Continente: diante das reduzidas dimensões de parte dos países-membros dessa grande comunidade, não raras vezes se sofre em uma determinada nação os efeitos de emissões poluentes ou acidentes ocorridos em nação vizinha ou próxima. Por decorrência, antes que razões outras impusessem a consideração da questão ambiental pelo Direito, já na Europa as relações internacionais passaram a adotar o ponto como item da agenda regular.

\section{- o cenário interno}

No que tange ao Brasil, o cenário era completamente diverso à época. Entre 1968 (data do Clube de Roma) e 1972 (realização da Conferência de Estocolmo), vivia nosso País sob regime de exceção, no qual os direitos individuais eram nem sempre respeitados. Um dos pilares de sustentação e justificação do regime então imposto ao País, como se sabe, era o da necessidade do desenvolvimento econômico. Dalia Mainon ${ }^{14}$, ao cuidar do ponto, afirma que a posição oficial do país, à época, era a de que as agressões à natureza eram secundárias em relação à necessidade de crescimento econômico.

E mais: a questão da defesa do meio ambiente, à época, suscitava ressalvas no meio jurídico, por conta das características diversas da linha tradicionalista do Direito, voltada aos direitos individuais. Veja-se o comentário de Juliana Santilli ${ }^{15}$, ao caracterizar o que denomina de "novos direitos", entre os quais se situa o direito ambiental:

Os "novos direitos" rompem com os paradigmas da dogmática jurídica
tradicional, contaminada pelo apego ao excessivo formalismo, pela falsa
neutralidade política e científica e pela excessiva ênfase nos direitos
individuais, de conteúdo patrimonial e contratualista, de inspiração
liberal. Os "novos" direitos, conquistados por meio de lutas sociopolíticas
democráticas, têm natureza emancipatória, pluralista, coletiva e
indivisível, e impõem novos desafios à ciência jurídica, tanto do ponto de
vista conceitual e doutrinário quanto do ponto de vista de sua
concretização.

\footnotetext{
${ }^{14}$ MAINON, Dalia. Mudança da política ambiental. In: MACIEL, Tania (Org.). $O$ ambiente inteiro: a contribuição crítica da universidade à questão ambiental. Rio de Janeiro: UFRJ, 1992. p. 266.

${ }^{15}$ SANTILLI, Juliana. Socioambientalismo e novos direitos: proteção jurídica à diversidade biológica e cultural. Editora Peirópolis, 2005. In:: WOLKMER, Antonio Carlos; LEITE, José Rubens Morato (Orgs.). Os "novos" direitos no Brasil: natureza e perspectivas. São Paulo: Saraiva, 2003. p. 58.
} 
O trabalho de Juliana Santilli encontra suporte em Norberto Bobbio ${ }^{16}$ e Jean Rivera $^{17}$. Confira-se:

Do ponto de vista teórico, sempre defendi - e continuo a defender, fortalecido por novos argumentos - que os direitos do homem, por mais fundamentais que sejam, são direitos "históricos", ou seja, nascidos em certas circunstâncias, caracterizadas por lutas em defesa de novas liberdades contra velhos poderes, e nascidos de modo gradual, não todos de uma vez e de uma vez por todas.

A figura dos direitos de terceira geração foi introduzida na literatura cada vez mais ampla sobre os "novos direitos". No artigo "Sobre la evolución contemporánea de la teoría de los derechos del hombre", Jean Rivera inclui entre esses direitos os direitos de solidariedade, o direito ao desenvolvimento, à paz internacional, a um ambiente protegido, à comunicação.

Para além de trazerem essa concepção nova, da quebra de estruturas e paradigmas, os novos direitos carregavam consigo dificuldade outra para sua aceitação pela doutrina tradicionalista. Retome-se o comentário de Juliana Santilli ${ }^{18}$, que, citando Antonio Carlos Wolkmer, assim coloca a inovação trazida:

(...) e não se enquadram [os "novos" direitos] nos estreitos limites do dualismo público-privado, inserindo-se dentro de um espaço público não estatal. Doutrinariamente, são classificados como direitos de "terceira dimensão" por serem de titularidade coletiva, e não individual.

O cenário, bem se vê, era portanto de extrema dificuldade para que, tanto no campo político-social, quanto no jurídico, se aceitasse sem ressalvas, e sem resistência, ideias e propostas que teriam efeito modificador - radical - sobre um plano de Governo e de desenvolvimento. Toda e qualquer proposta que trouxesse o meio ambiente como bem jurídico sob tutela - ainda que tal proposta apenas servisse para disfarçar interesses verdadeiros outros, de ordem econômica - enfrentaria esses obstáculos.

De fato, não contava o Brasil, à época, com estrutura jurídico-política voltada especificamente à proteção ambiental. Os diplomas legais que de alguma forma traziam em seu cerne a proteção ambiental, então vigentes, sempre tinham a questão de proteção ambiental como item subjacente à ratio principal que os informava. Assim é no que toca ao

\footnotetext{
${ }^{16}$ BOBBIO, Norberto. A era dos direitos. 19. tir. São Paulo: Ed. Campus, 2004.

${ }^{17}$ Id. Ibid., citando Jean Rivera, nas "Notas" à Introdução.

${ }^{18}$ SANTILLI, Juliana. op. cit., p. 9 e ss.
} 
Código de Águas, de 1934, no Código Florestal, em sua edição primeira, de 1934, e segunda, de 1965, entre outros diplomas.

Tais instrumentos de regulação legal traziam como foco central de seus regramentos a proteção de um recurso de potencial exploração de natureza econômica. Por outras palavras, não recebiam proteção legal as águas e as florestas por conta de seu valor ambiental, mas antes e especificamente por conta de sua exploração econômica é que recebiam proteção legal. A visão do período da Coroa, e do modo pelo qual a natureza e os recursos naturais eram vistos nas fases primeiras, como mero elemento de apropriação econômica, ainda prevalecia aqui.

Não é de se estranhar, pois, que o movimento que começou a tomar corpo em 1968, e que se revelou efetivo em 1972, não recebesse, no Brasil, aceitação plena e pronta, sem ressalvas ou resistências efetivamente audíveis por alguns de nossos meios formadores de opinião.

\section{- o Brasil em Estocolmo: o início da postura de liderança}

Sob essa situação paradoxal, ou seja, da dicotomia entre adaptar-se ao cenário internacional, devendo para tanto inserir a questão ambiental em sua agenda, e a necessidade de manutenção do firme propósito desenvolvimentista, é que nosso País enviou representação à Conferência de Estocolmo.

Muito já se disse a respeito. Há quem afirme, de forma peremptória, que a postura brasileira teria sido vacilante, tímida, enquanto outros sustentam ter o Brasil tomado postura de frente e vanguarda, seja para questionar a viabilidade da proteção ambiental pretendida, seja, conforme defendem outros, para agir de maneira pró-ativa e inovadora, na forma do indicado por ainda outros. O já citado Edis Milaré ${ }^{19}$ assim define a participação brasileira em Estocolmo:

Nesse evento, sabe-se, os países do Terceiro Mundo, liderados pelo Brasil, passaram a questionar a postura dos países ricos, que, tendo atingido pujança industrial com o uso predatório de recursos naturais, queriam agora retardar e encarecer a industrialização dos países subdesenvolvidos, impondo-lhes complexas exigências de controle ambiental; isso, porém, levaria a que os ricos continuassem sempre ricos,

\footnotetext{
${ }^{19}$ MILARÉ, Edis. op. cit., p. 140.
} 
e os pobres permanecessem sempre e irremediavelmente pobres. "A maior poluição é a pobreza" e "a industrialização suja é melhor do que a pobreza limpa" eram os slogans terceiro-mundistas.

Roberto P. Guimarães ${ }^{20}$ pondera que, para além de ser simplesmente uma postura de contraposição à intenção dos países desenvolvidos, a atuação brasileira em Estocolmo revela liderança, coerência histórica e, mais ainda, provou-se vencedora em quase todos os pontos a que se apegou :

Como é de todos conhecido, ainda que nem sempre corretamente compreendido, o governo brasileiro teve uma destacada posição de liderança antes, durante e depois da conferência. Independente do caráter obstrucionista ou antiambientalista que boa parte dos meios de comunicação atribuiu ao desempenho da delegação brasileira, o certo é que, com exceção da disputa com a Argentina a respeito da construção de Itaipu, todas as propostas brasileiras saíram vitoriosas de Estocolmo, e com absoluto respaldo dos países do Terceiro Mundo.

A posição que o governo brasileiro levou à conferência pode ser resumida a três elementos. Em primeiro lugar, o processo de desenvolvimento não deveria ser sacrificado em nome de um meio ambiente menos contaminado. Em segundo lugar, se grande parte da degradação ambiental do planeta, resulta das atividades industriais do mundo desenvolvido, os países que o compõem deveriam responsabilizar-se pelo custo de restaurar a qualidade do meio ambiente. Finalmente, o elemento que provocou mais controvérsia: o de que não se poderia renunciar à soberania nacional em troca de "interesses ambientalistas" pouco claros. À luz das frequentes denúncias de destruição em larga escala da floresta amazônica, muitos interpretaram essa postura como anti-meio ambiente, quando, na verdade, ela refletia uma tradição da diplomacia brasileira: a de que a cooperação internacional termina onde começa o interesse nacional estratégico.

De especial importância o comentário de Roberto P. Guimarães, porquanto revela aspectos múltiplos da postura e conduta governamental brasileira. O ponto primeiro a merecer destaque é o referente à Usina de Itaipu. Implantada por conta de Tratado Bilateral entre Brasil e Paraguai (Tratado entre a República Federativa do Brasil e a República do Paraguai para o aproveitamento hidroelétrico dos recursos hídricos do Rio Paraná, pertencentes em condomínio aos dois Países, desde e inclusive o Salto Grande de Sete Quedas ou Salto de Guairá até a Foz do Rio Iguaçu, incorporado ao direito positivo brasileiro pelo Decreto Legislativo $\mathrm{n}^{\circ} 23$, de 30.5.1973 e pelo Decreto $\mathrm{n}^{\circ} 72.707$, de

${ }^{20}$ GUIMARÃES, Roberto P. Ecologia e política na formação social brasileira. Dados: revista de ciências sociais, Rio de Janeiro, v. 1, n. 2, 1988. 
28.8.1973), a Usina Hidrelétrica de Itaipu, à época de sua implantação, para além de representar um acréscimo na capacidade de geração de energia para Brasil e Paraguai, representou também incidente diplomático de grandes proporções com a Argentina, uma vez que, instalada em local estratégico, a barragem da usina de Itaipu pode representar não apenas instrumento de controle de volume de água a jusante, na Bacia do Rio da Prata, mas pode também representar risco de inundação, ainda que teórico e de reduzidas proporções, sobre o território portenho.

Diante dessa situação, a reação Argentina à implantação de Itaipu foi dura, e envolveu a alegação de aspectos de natureza ambiental para se demonstrar oposição à sua implantação. O Brasil, no entanto, apegado à sua tradição destacada por Roberto $\mathrm{P}$. Guimarães, levou à discussão o argumento de que se estaria diante de empreendimento de relevância para a manutenção da segurança nacional, não se justificando, pois, dar ouvidos aos reclamos argentinos.

De outro lado, Itaipu revela a competência diplomática brasileira, pelo fato de que o tratado Bilateral entre Brasil e Paraguai trata de tema denso, qual seja, empreendimento conjunto entre dois Estados, fazendo-o de forma direta, simples e objetiva.

O ponto segundo a merecer aqui comentário é o atinente à defesa, pela representação brasileira na Conferência de Estocolmo, do conceito de que o processo de desenvolvimento não deveria ser sacrificado em nome de um meio ambiente menos contaminado 21. Essa postura, revelada de forma peremptória pela representação brasileira em Estocolmo, demonstra a oposição, ainda que relativa, à quebra de paradigma que se interpretou estaria o Clube de Roma a sugerir. O Brasil demonstrava o forte propósito de manter em vigor a política desenvolvimentista então em efeito, de forma que, ainda que aceitando a discussão quanto à necessidade de proteção do meio ambiente, estabeleceu-se ali como condicionante para tais discussões o não comprometimento ou redução do ritmo de crescimento.

Corajosa a postura brasileira, porque contraposta à noção que então dominava o pensamento geral, de que a preservação dos recursos naturais que se descobrira finitos pressuporia redução dos níveis de apropriação e uso desses recursos, o que por decorrência implicaria reduzir níveis de crescimento.

\footnotetext{
${ }^{21}$ GUIMARÃES, Roberto P. op. cit.
} 
Vista de maneira isolada, essa postura pode parecer não ter forças para se sustentar, porque paradoxal. Ocorre que sua análise deve ser realizada em conjunto com a postura segunda revelada pela representação diplomática brasileira, a de que se grande parte da degradação ambiental do planeta resulta das atividades industriais do mundo desenvolvido, os países que o compõem deveriam responsabilizar-se pelo custo de restaurar a qualidade do meio ambiente ${ }^{22}$.

Tal afirmação é ainda mais contundente e corajosa que a anterior. Em contraposição à postura que se quis inferir da tese defendida pelo Clube de Roma, de que ali se estaria pregando a manutenção do status quo econômico, em nome da preservação ambiental, sustentou, pois, o Brasil que se definisse de forma proporcional a responsabilidade pela recuperação ambiental. O que buscou a representação diplomática brasileira, portanto, foi a inserção do conceito que hoje se denomina de responsabilidade comum, mas diferenciada. Tal conceito, hoje aceito em larga escala, encontra exemplo de grande importância na estrutura estabelecida no Protocolo de Quioto, instrumento vinculado ao combate à mudança do clima.

Eis pois que já àquela época, diante da proposta de quebra do paradigma do desenvolvimento suportado pelo uso até irracional e desmedido de recursos naturais, buscou o Brasil garantir que a proteção proposta para o meio ambiente não significasse vilipendiar o direito ao desenvolvimento econômico das nações menos privilegiadas, sugerindo para tanto o estabelecimento de regras de responsabilização diferenciada, baseada na contribuição de cada Estado para a devastação ambiental antes ocorrida.

Por fim, defendeu ainda a delegação brasileira em Estocolmo que não se poderia renunciar à soberania nacional em troca de “interesses ambientalistas",23. O conceito, bem afeto à postura tradicional de nosso corpo diplomático, induz a ideia de que, no plano internacional, não aceitaria nosso País qualquer tipo de ingerência ou interferência no poder decisório acerca de todo e qualquer bem ou interesse de cunho nacional. Iniciada em 1972, essa postura até hoje encontra campo fértil para o debate, uma vez que a questão da Amazônia ganha a cada dia mais destaque, no que toca às propostas para sua internacionalização. Nosso corpo diplomático vem nesse período sempre defendendo a tese da soberania, sempre que posta à discussão.

\footnotetext{
${ }^{22}$ GUIMARÃES, Roberto P. op. cit.

${ }^{23}$ Id. Ibid.
} 
Como reflexo dessa postura, no campo interno, à época, projetos e empreendimentos havidos como de interesse nacional estratégico, pelo Governo, eram entendidos como isentos do atendimento às regras ambientais, pela sua natureza de necessários à segurança nacional. Por anos prevaleceu esse entendimento.

Este o contexto em que o Brasil se inseriu na questão ambiental. Firme em seus propósitos, nossa representação diplomática marcou posição de forma contundente, preservando para si a soberania e o direito de prosseguir com o plano de desenvolvimento nacional, sem que com isso se recusasse participação ativa e de liderança no processo de criação de princípios e legislativa de âmbito internacional para proteção ambiental.

Como resultado da Conferência de Estocolmo, aprovou-se a Declaração de Estocolmo (Declaração das Nações Unidas Sobre o Meio Ambiente), documento que enumera 26 princípios a serem observados pelas Nações signatárias, e estabeleceu-se um Plano de Ação, com 109 recomendações, centradas em três grandes tipos de políticas, quais sejam, as tocantes à avaliação do Meio Ambiente (o Earthwatch); as referentes à gestão ambiental; e as voltadas às medidas de apoio, tais como informação, educação e formação de especialistas.

Ainda por conta da Conferência de 1972 aprovou-se o Programa das Nações Unidas sobre o Meio Ambiente - PNUMA, órgão subsidiário da Assembleia Geral da ONU, sediado em Nairóbi, no Quênia.

Por fim, estabeleceu-se como agenda a realização de reuniões outras, voltadas à verificação dos avanços e correções necessárias.

A Conferência de 1972, nos dizeres de Philippe Sands ${ }^{24}$, estabeleceu o cenário para atividades internacionais nos níveis regional e global, e influenciou o desenvolvimento legal e institucional para e além da Conferência das Nações Unidas para o Meio Ambiente e Desenvolvimento - UNCED.

\footnotetext{
${ }^{24}$ SANDS, Philippe. Principles of international environmental law. 2. ed. Cambridge: Cambridge University Press, 2003. p. 40.
} 
José Afonso da Silva ${ }^{25}$ destaca:

A Declaração de Estocolmo abriu caminho para que as constituições supervenientes reconhecessem o meio ambiente ecologicamente equilibrado como um direito fundamental entre os direitos sociais do Homem, com sua característica de direitos a serem realizados e direitos a não serem perturbados.

\section{- de Estocolmo ao relatório Brundtland}

Ocorre que, apesar das intenções preservacionistas e de recuperação que marcaram a reunião de Estocolmo, e sem prejuízo do fato de tal evento representar marco histórico, dando espaço e servindo como propulsor a ações globais e regionais, o que se viu, no campo internacional, após a reunião de Estocolmo, é que pouco se evoluiu, em termos práticos, no trato da questão ambiental.

Desse estado de não consecução de objetivos é que decorreu a iniciativa da Assembleia Geral da ONU de fazer realizar relatório acerca do andamento da questão, relatório este que, preparado sob a coordenação de Gro Harlem Brundtland, estabeleceu as diretrizes, as vigas de orientação para que, em 1992, no Rio de Janeiro, se chegasse ao texto da Convenção-Quadro sobre a Mudança do Clima, entre outros avanços ali obtidos. Vale conferir o magistério de Geraldo Eulálio do Nascimento e Silva ${ }^{26}$ :

DECORRIDOS DEZ ANOS desde a Conferência de Estocolmo, a comunidade internacional constatava, com compreensível preocupação, que aumentava a destruição do meio ambiente, bem como o uso indiscriminado dos recursos não renováveis da natureza. As organizações internacionais, quer as intergovernamentais quer as não governamentais, sentiam-se frustradas em suas tentativas no sentido de criar normas legais destinadas a impedir este estado de coisas. Os poucos tratados internacionais firmados consolidavam a chamada soft law em que exortavam as partes contratantes a agir desta ou daquela maneira, mas sem adotar normas capazes de obrigá-las a tanto.

\section{$(\ldots)$}

Em 1983, dando prosseguimento aos seus trabalhos, a Assembléia Geral das Nações Unidas criou a Comissão Mundial sobre Meio Ambiente e Desenvolvimento, para cuja presidência foi escolhida a Senhora Gro Harlem Brundtland, da Noruega, a única estadista do mundo designada para o cargo de Primeiro-Ministro, depois de haver ocupado a pasta de

\footnotetext{
${ }^{25}$ SILVA, José Afonso da. Direito ambiental constitucional. 2. ed. rev. São Paulo: Malheiros Ed., 1995. p. 69-70.

${ }^{26}$ SILVA, Geraldo Eulálio do Nascimento e. Direito ambiental internacional. Rio de Janeiro: Thex Ed., 1995. p. 33-35.
} 
Meio Ambiente. A Comissão era composta de dez membros escolhidos entre representantes de países em desenvolvimento e dez de países desenvolvidos, além do Presidente e do Vice-Presidente. Dentre os membros, cumpre mencionar o nome de Paulo Nogueira Neto, do Brasil, que teve papel de destaque.

No dizer de Brundtland, "o que a Assembléia Geral solicitava parecia irrealista e ambicioso demais, embora fosse também uma evidente demonstração do sentimento generalizado na comunidade internacional, de frustração e inadequação no tocante à nossa capacidade de enfrentar as questões vitais do mundo e lidar bem com elas".

Durante três anos, a Comissão visitou todos os países, consultou dezenas de pessoas e realizou reuniões deliberativas em diversas cidades, inclusive Brasília. Encerrou oficialmente as suas atividades em 31 de dezembro de 1987, com a entrega de seu Relatório à Assembléia Geral das Nações Unidas.

O Relatório, ao abordar os principais problemas, dá especial ênfase às consequiências negativas da pobreza sobre o meio ambiente.

\section{$(\ldots)$}

A Comissão classificou em três grandes grupos os principais problemas ambientais. $\mathrm{O}$ primeiro versa sobre problemas ligados à poluição ambiental, trata das emissões de carbono e das mudanças climatológicas, a poluição da atmosfera, a poluição da água, dos efeitos nocivos dos produtos químicos e dos rejeitos nocivos, dos rejeitos radioativos e a poluição das águas interiores e costeiras.

O que se vê, portanto, é que a temática trazida à discussão pela diplomacia brasileira, em 1972, foi ao depois posta, no Relatório Brundtland, como fator de relevância maior para as mazelas ambientais, quando este atribui à pobreza a ocorrência de agressões e danos ao meio ambiente. A necessidade de trato da questão pobreza versus preservação ambiental, ou ainda dignidade versus preservação ambiental, não deixou mais de ser item primordial na agenda de discussões internacionais, prevalecendo até hoje esse estado de coisas. 


\section{- os efeitos de Estocolmo sobre o Brasil - o marco legal interno e a consagração de uma postura}

Paralelamente à percepção de que o evento de Estocolmo não gerou efeitos positivos imediatos, a partir de 1972 avolumou-se a pressão e a necessidade de criação, no Brasil, de estrutura própria de controle e fiscalização ambiental. Não tardou a resposta primeira, ainda que tímida, a tal estímulo: em 1973 criou-se, por meio do Decreto $\mathrm{n}^{\circ}$ 73.030, a Secretaria Especial do Meio Ambiente - SEMA.

Na obra já citada, Roberto P. Guimarães ${ }^{27}$ bem destaca o contexto da criação da SEMA:

O momento vivido pelo País nessa época influenciou decididamente a criação, o desenho institucional e o próprio funcionamento da SEMA. Nesse sentido, é importante destacar que o documento elaborado pelo Itamaraty contendo a posição oficial da delegação brasileira a ser defendida em Estocolmo já previa o estabelecimento de um órgão com atribuições normativas e de coordenação na área do meio ambiente. Como vimos, no início dos anos 60 muitos estados brasileiros contavam com uma agência de controle ambiental. O próprio Congresso, no final da década, chamou a atenção para a necessidade de formulação de uma política nacional de meio ambiente. Em 1967 se estabelece política nacional de saneamento. Neste mesmo ano cria-se, no Ministério da Saúde, o Conselho Nacional para Controle da Poluição Ambiental.

Dois "detalhes" adicionais explicam o nascimento da SEMA. O primeiro deles, até há pouco despercebido mas fundamental, se resume na assinatura que aparece na Exposição de Motivos no 100/71 do Conselho de Segurança Nacional - CSN, documento que aprova a posição oficial sugerida pelo Itamaraty e que contém todos os aspectos relevantes da "ideologia" oficial no que se refere aos assuntos ambientais, muitos dos quais permanecem vigentes até hoje. Essa assinatura não teria maior transcendência se não fosse do então general-de-brigada João Baptista Figueiredo, secretário-geral do CSN em 1971, que, como sabemos, pouco depois se tornaria Chefe do Serviço Nacional de Informações, um dos postos mais altos na hierarquia do regime militar, e, posteriormente, Presidente da República. Que essa documentação houvesse passado pelo crivo cuidadoso do CSN significava, de fato, o nihil obstat para o estabelecimento da SEMA.

O comentário de Roberto P. Guimarães revela a posição de submissão da questão ambiental aos interesses econômicos. A pretendida criação de um mecanismo de defesa ambiental interno somente se tornou possível após o aval do Conselho de Segurança Nacional - CSN, órgão então secretariado pelo General Figueiredo, zeloso garantidor dos

\footnotetext{
${ }^{27}$ GUIMARÃES, Roberto P. op. cit.
} 
caminhos para o nosso desenvolvimento industrial.

Sintomático do pouco caso diante da questão ambiental, o histórico da criação da SEMA revela a contraposição, aqui ainda embrionária, entre a postura de Governo e o ânimo social. Ao mesmo tempo, pois, em que revela o descaso do Governo, demonstra o episódio que já se iniciava, no País, a conscientização diante da causa ambiental. Roberto P. Guimarães encerra o comentário acerca do ponto destacando que, por conta das circunstâncias de criação da SEMA, desenvolveu-se internamente uma "cultura" de controle ambiental voltada ao abrandamento de contaminações, diversa da postura que a própria Nação já adotava na esfera internacional, de participação na busca de gestão eficiente de recursos naturais.

Observando os acontecimentos históricos de forma um pouco menos crítica, Elida Séguin ${ }^{28}$ pondera que a Conferência de Estocolmo, em 1972, foi um marco para os movimentos sociais, que terminaram por impor frutos na legislação brasileira, que timidamente começou a regulamentar a devastação desenfreada do nosso patrimônio ambiental.

Nesse estado de coisas é que surgiu o marco primeiro da adoção, pelo Brasil, de um sistema voltado à proteção ambiental. Ainda transpassado pelo peso maior do conceito econômico, o órgão criado veio, em sua essência, para significar uma resposta burocrática e exclusivamente formal à pressão sofrida pelo Estado brasileiro interna e internacionalmente, diante da necessidade da adoção de postura firme de liderança no cenário da proteção ambiental.

Mas, como destaca Roberto P. Guimarães, ainda que surgida sob esse manto, a criação da SEMA logrou estabelecer ponto de partida para o desenvolvimento de um novo sistema.

Os Estados do Rio de Janeiro e de São Paulo, sempre pioneiros, estabeleceram na década de 70 seus sistemas estaduais de proteção ambiental, antecipando o inevitável: a crescente conscientização da Nação quanto à questão ambiental necessariamente imporia ao Governo adotar sistema próprio, de âmbito federal, para a proteção do meio ambiente.

A Lei $\mathrm{n}^{\mathrm{o}}$ 6.902, de 27 de abril de 1981, concretizou o primeiro movimento de atendimento a essa necessidade, ao dispor sobre a criação de Estações Ecológicas, Áreas de Proteção Ambiental e outras providências. Em seguida, veio a materialização do

\footnotetext{
${ }^{28}$ SÉGUIN, Elida. O direito ambiental: nossa casa planetária. 2. ed. Rio de Janeiro: Forense, 2002. p. 51.
} 
inevitável: em 31 de agosto de 1981, o então Presidente da República General João Baptista de Figueiredo, cujo relatório levara à criação da SEMA, sancionou a Lei no 6.938, que estabeleceu a Política Nacional do Meio Ambiente, fundada em dois princípios fundamentais do Direito Ambiental:

(i) o princípio do poluidor-pagador, segundo o qual, sob a visão tradicional a si dada pela doutrina, aquele que traz em sua atividade o risco de poluir deve internalizar os custos correspondentes; o termo pode dar azo à equivocada interpretação que se pagaria pelo direito de poluir, o que não condiz com a realidade; seria mais adequado tê-lo nomeado à forma como fizeram os japoneses, que o inseriram em seu sistema sob a denominação de osen futan gensoku, que significa princípio da assunção da carga poluidora; e

(ii) o princípio da prevenção (e também, para parte da doutrina, o princípio da precaução estaria também no sistema então criado), daí derivado, segundo o qual deve-se adotar, para o exercício de atividades de risco ambiental, todas as medidas de eliminação, redução, controle e minimização de tais riscos, de forma a que as externalidades negativas decorrentes do exercício da atividade de risco sejam a tal grau reduzidas, que se tornem absorvíveis pela sociedade, em razão dos benefícios auferidos, em escala desproporcionalmente maior, como resultado da atividade.

Marco divisor de águas em nossa história, abraçou tal Lei a proteção do meio ambiente como bem objeto de tutela legal em si. Ainda assim, bom destacar, não se conseguiu, naquele momento, o total desprendimento das amarras que condicionavam qualquer sistema dentro de nosso Estado à observância dos aspectos econômicos e da segurança nacional. Essa a conclusão a que chegará o intérprete que se detiver no texto do artigo $2^{\circ}$ da Lei:

Art $2^{\circ}$ - A Política Nacional do Meio Ambiente tem por objetivo a preservação, melhoria e recuperação da qualidade ambiental propícia à vida, visando assegurar, no País, condições ao desenvolvimento socioeconômico, aos interesses da segurança nacional e à proteção da dignidade da vida humana, atendidos os seguintes princípios:

I - ação governamental na manutenção do equilíbrio ecológico, considerando o meio ambiente como um patrimônio público a ser necessariamente assegurado e protegido, tendo em vista o uso coletivo; 

II - racionalização do uso do solo, do subsolo, da água e do ar;
III - planejamento e fiscalização do uso dos recursos ambientais;
IV - proteção dos ecossistemas, com a preservação de áreas representativas;
$\mathrm{V}$ - controle e zoneamento das atividades potencial ou efetivamente poluidoras;

VI - incentivos ao estudo e à pesquisa de tecnologias orientadas para o uso racional e a proteção dos recursos ambientais;

VII - acompanhamento do estado da qualidade ambiental;

VIII - recuperação de áreas degradadas;

IX - proteção de áreas ameaçadas de degradação;

$\mathrm{X}$ - educação ambiental a todos os níveis de ensino, inclusive a educação da comunidade, objetivando capacitá-la para participação ativa na defesa do meio ambiente.

Bem se vê, a preservação, melhoria e recuperação da qualidade ambiental a que se refere a Lei vincula-se, de um lado, à visão antropocêntrica, posto voltar o texto legal tal preservação, melhoria e recuperação, sempre, ao alcance da qualidade de vida. De outro lado, o texto da lei impõe que tal busca pela preservação, melhoria e recuperação da qualidade ambiental deve ter por foco assegurar condições ao desenvolvimento socioeconômico, aos interesses da segurança nacional e à proteção da dignidade da vida humana.

Ora, essa construção do texto legal revela a prevalência ainda do antropocentrismo e da busca pelo desenvolvimento socioeconômico como princípios postos acima, ou no máximo no mesmo patamar da questão ambiental. Mas o avanço, ainda assim, foi grande.

Dentre vários pontos que merecem destaque na estrutura criada pela Lei, merecem especial atenção os fatos de que a lei estabeleceu a responsabilidade objetiva em matéria civil diante do dano ao meio ambiente, ao mesmo tempo em que regrou a responsabilidade administrativa ambiental e apontou para a possibilidade de responsabilização penal do infrator ambiental. A adoção do conceito da responsabilidade objetiva em matéria civil ambiental representou avanço que, pela quebra do paradigma da responsabilidade subjetiva, aquiliana, que tradicionalmente orienta o nosso sistema, proporcionou ambiente fértil para que, a tempo e modo, os sistemas outros fossem aceitos por nossa sociedade, 
notadamente, porque aqui objeto de estudo, o conceito da responsabilidade comum mas diferenciada, que nossa diplomacia já defendia no campo internacional, mas que nossa sociedade, em 1981, ainda não estava preparada a assumir e compreender em sua absoluta extensão e grandeza.

Um tripé se criou ali: prevenir, restaurar e reparar o meio ambiente, nesta ordem, constituem os focos da lei: pelos mecanismos de comando e controle previstos e estabelecidos, passou-se a exercer o controle prévio das atividades potencialmente degradadoras, pelo exercício do licenciamento ambiental; estabeleceu-se o controle fiscalizatório, pela aplicação do poder de polícia; e previu-se a imposição de sanções, de controle de conduta na esfera administrativa e na esfera penal, e de busca da restauração ou reparação do dano na esfera civil, privilegiando-se a restauração, para que se tenha a reparação apenas quando impossível restaurar.

\section{- o marco constitucional (e o destaque ao tema objeto deste trabalho)}

Apesar de a Lei $n^{\circ}$ 6.938/81 representar a inserção da questão ambiental como elemento objeto de política pública de âmbito nacional em nosso país, faltava ainda o trato do tema no campo constitucional. Tal lacuna restou superada com a promulgação da Constituição Federal de 5.10.1988, que dedicou ao meio ambiente o Capítulo VI de seu Título VIII, que de sua parte trata da Ordem Social.

A inserção da tutela do meio ambiente na Carta Magna veio na esteira da apropriação, pela sociedade, da consciência da necessidade de alterar a relação entre homem e Natureza. Norma Sueli Padilha ${ }^{29}$ bem destaca a alteração havida entre a relação mantida entre o ser humano e a Natureza, antes, e a já então absorvida em sua nova dimensão:

"O papel do Direito na condução e orientação do comportamento humano
na sociedade objetiva, sempre, a imposição de limites, de um controle do
agir individual diante do outro, seja ele também individual ou coletivo.
Limites que exigem um comportamento de mínimo respeito e
consideração ao interesse dos demais.
Não é diferente o papel do Direito Ambiental enquanto condicionador de
comportamentos humanos. Entretanto, o outro a ser minimamente

${ }^{29}$ PADILHA, Norma Sueli. Fundamentos constitucionais do direito ambiental brasileiro. Rio de Janeiro: Elsevier, 2010. p. 217 e ss. 
respeitado ou considerado não é um outro indivíduo ou apenas uma coletividade deles, mas importa na introdução no universo das relações jurídicas de um novo ator a ser levado em consideração - a Natureza.

E a Natureza, não mais apenas como objeto de apropriação, como passível de uso indiscriminado pela lógica racionalista do mercado de produção e consumo, mas como agente que possui vida, um ser vivo, que, como todos os demais, está sujeito aos limites da morte, de uma continuidade subordinada ao tempo e ao cuidado, de uma preservação que exige responsabilidade e preocupação."

O texto conferido ao tema, forte e elogiado pela doutrina especializada, traz vários conceitos e princípios. Vale conferir o texto e seu conteúdo:

Art. 225. Todos têm direito ao meio ambiente ecologicamente equilibrado, bem de uso comum do povo e essencial à sadia qualidade de vida, impondo-se ao Poder Público e à coletividade defendê-lo e preservá-lo para as presentes e futuras gerações.

Vários são os paradigmas alterados pelos conceitos e princípios introduzidos pelo texto constitucional:

\section{(i) universalidade do direito}

O texto constitucional consagra o direito ao meio ambiente a todos, significando o termo "todos", sob interpretação mais adequada à teoria da sustentabilidade ${ }^{30}$, que os titulares de tal direito não se resumem aos seres humanos, abrangendo também, sob a tutela do Estado e da sociedade, não apenas estes, mas também os animais, os ecossistemas, as florestas, e os elementos que as compõem, estabelecendo uma nova visão acerca da abrangência de aplicação do direito;

\section{(ii) Bem de uso comum e o desenvolvimento da noção de bem ambiental}

Na forma do artigo 99, I, do Código Civil, o meio ambiente é havido, na forma do artigo 225 da $\mathrm{CF}$, como um bem público, referendando-se, pois, sua natureza difusa. Aqui compete, no entanto, um comentário, desde logo: ao se tratar da questão da abordagem do

\footnotetext{
${ }^{30}$ Sustentabilidade, para Monzoni e Llosa, seria um processo que abrange avaliação do cumprimento das normas ambientais (tais como as normas de licenciamento ambiental), engajamento da sociedade e partes interessadas, consulta pública, transparência e avaliação de impactos ambientais, sociais e econômicos.
} 
meio ambiente como bem sujeito à tutela pelo sistema, vem a doutrina entendendo ser necessário dar classificação específica ao assim denominado "bem ambiental", que seria um bem destacado da categoria dos bens públicos, algo como um terceiro gênero de bem, conforme explica Fiorillo, para quem a Constituição Federal "formulou inovação revolucionária no sentido de criar um terceiro gênero de bem, que, em face de sua natureza jurídica, não se confunde com os bens públicos e muito menos com os privados" ${ }^{31}$, mas seria, ainda nos dizeres do festejado Professor, um bem que se estrutura sob duas premissas: a de ser um bem de uso comum do povo, e de apresentar-se como essencial à sadia qualidade de vida.

O bem ambiental, Segundo Rui Carvalho Piva, consistiria em "um valor difuso, imaterial ou material, que serve de objeto mediato a relações jurídicas de natureza ambiental" 32 .

Assim, o que se vê, quando se aborda a questão do Direito Ambiental para efeitos de estudo, é que o bem de que ali se trata e tem sob tutela, o dito bem ambiental, apresentase sob uma natureza sui generis, já que não se insere na categoria dos bens de ordem privada, nem tampouco na dos bens de ordem pública, mas em uma terceira categoria, em que se tem um bem difuso, apropriável pelo particular para uso, mas jamais transferível ao seu domínio, nem tampouco sujeito a livre apropriação pelo ente público, já que sua natureza difusa o coloca sob guarda e direito de todos.

\section{(iii) Essencialidade à sadia qualidade de vida}

A CF reconhece a meio ambiente equilibrado como item essencial à sadia qualidade de vida, condição fundamental à consecução do segundo fundamento de nosso sistema (artigo $1^{\circ}$, II, da CF), qual seja, a cidadania;

\section{(iv) $O$ dever de defesa e preservação}

A CF expressamente impõe ao Poder Público e à coletividade o dever de defesa e preservação do meio ambiente, ampliando, pois, o alcance de tal dever, antes atribuído de forma mandatória apenas ao Poder Público; e

\footnotetext{
${ }^{31}$ FIORILlO, Celso Antônio Pacheco. Curso de direito ambiental brasileiro. São Paulo: Saraiva, 2000.

${ }^{32}$ PIVA, Rui Carvalho. Bem ambiental. São Paulo: Max Limonad, 2000.
} 


\title{
(v) O caráter intergeracional do meio ambiente
}

Aqui, certamente, o mais contundente dos princípios trazidos pela $\mathrm{CF}$ : os princípios, conceitos, deveres e obrigações atrelados ao dever de defesa e preservação do meio ambiente - trazidos no caput do artigo 225 da CF, detalhados em seus incisos e parágrafos, e normatizados em legislação ordinária - deixam de estar situados no tempo e no espaço, assumindo caráter intergeracional. Por outras palavras, o objetivo final da defesa e preservação do meio ambiente deve ter como escopo o alcance de seus resultados preservacionistas não apenas no agora, mas igualmente no futuro, para as futuras gerações.

Tal postura caminha em linha com a preocupação que já havia sido destacada no Relatório Brundtland ${ }^{33}$, que chama a atenção para o fato de que a conduta de hoje deve ser controlada, porque afeta o direito das gerações futuras:

\begin{abstract}
"Tomamos um capital ambiental emprestado às gerações futuras, sem qualquer intenção ou perspectiva de devolvê-lo. Elas podem até nos maldizer por nossos atos perdulários, mas jamais poderão cobrar a dívida que temos para com elas. Agimos dessa forma porque podemos escapar impunes: as gerações futuras não votam, não possuem poder político ou financeiro, não tem como opor-se a nossas decisões."
\end{abstract}

Importa notar que também outros sistemas adotam, hoje, este conceito como princípio constitucional, como é o caso da Constituição Portuguesa, que o denomina de princípio da solidariedade entre gerações, cujo significado, nos dizeres de Canotilho ${ }^{34}$, é o de obrigar as gerações presentes a incluir como medida de acção e de ponderação os interesses das gerações futuras.

De forma alinhada com o quanto antes já trazido pela Lei $n^{\circ} 6.938 / 81$, a CF elegeu o sistema de comando e controle como instrumento central para a implementação da defesa e preservação do meio ambiente. Tal instrumento se materializa por meio do licenciamento ambiental, introduzido pelo artigo 10 da Lei $n^{\circ} 6.938 / 81$, e referendado pela exigência de elaboração de estudo prévio de impacto ambiental, ferramenta que integra o licenciamento ambiental, pelo inciso IV do $\S 1^{\circ} \mathrm{d} 6$ artigo 225 da CF.

\footnotetext{
${ }^{33}$ COMISSÃO MUNDIAL SOBRE MEIO AMBIENTE E DESENVOLVIMENTO. Nosso Futuro Comum. 2. ed. Rio de Janeiro: FGV, 1991. p. 8.

${ }^{34}$ CANOTILHO, J.J. Gomes; LEITE, José Rubens Morato (Org.). Direito constitucional ambiental brasileiro. São Paulo: Saraiva, 2007. p. 8-9.
} 
Com efeito, esta a opção do legislador constitucional: dentre os mecanismos eleitos para a proteção ambiental, tais como a criação de espaços territoriais especialmente protegidos, destaca-se o licenciamento ambiental.

A opção do legislador encontra explicação, no que toca à Lei n$^{\circ} .6 .938 / 81$, no momento histórico atravessado pelo país quando de sua publicação. Sob o regime de exceção, o Estado de perfil intervencionista controlava a sociedade e a economia com pulso forte, e não poderia ser diferente para a inserção da variável ambiental na equação econômica. O Estado, por meio da legislação aplicável ao licenciamento ambiental, determinava os requisitos à obtenção do licenciamento (eis aqui o comando), realizando ao depois o controle por meio da fiscalização. A inovação trazida pela Lei nº . 6.938/81, já se destacou, residiu no estabelecimento da obrigação de reparação dos danos decorrentes do exercício da atividade produtiva, independentemente da aferição de culpa, ou seja, pela modalidade objetiva de responsabilização.

O foco no comando e controle se manteve no texto constitucional, quer-se acreditar, por força de três fatores: a uma, contando apenas sete anos o sistema inaugurado pela Lei $n^{\circ} 6.938 / 81$, ainda não se tinha período de aplicação longo o bastante para se poder avaliar a eficácia do licenciamento ambiental como ferramenta de harmonização entre crescimento econômico e proteção ambiental; a duas, porque não enxergava, o legislador constitucional, opções outras de comprovada eficácia para substituir ou complementar o sistema de comando e controle; e, por fim, por inércia, dado o fato de a Política Nacional de Meio Ambiente ser então relativamente recente (contando os sete anos acima destacados).

Igualmente no que toca aos efeitos negativos, indesejados, decorrentes da atividade produtiva, seguiu e referendou o texto constitucional o quanto já antes estipulado pela Lei $n^{\circ}$. 6.938/81: no $\S 3^{\circ}$ do artigo 225 definiu-se que as condutas e atividades consideradas lesivas ao meio ambiente sujeitarão os infratores pessoas físicas ou jurídicas, a sanções penais e administrativas, independentemente da obrigação de reparar os danos causados.

A doutrina especializada é praticamente unânime em entender ter sido a Lei $\mathrm{n}^{\circ}$. 6.938/81 recepcionada pelo sistema constitucional trazido pela CF de 5 de outubro de 1988, preservando-se e referendando-se o sistema de licenciamento ambiental, combinado com o peculiar sistema de responsabilidade nas três esferas, como mote central da implementação do dever de defesa e preservação ambiental. 
Assim, o que se conclui, do exame do texto constitucional no que toca ao meio ambiente, é que o legislador constitucional adotou como norte o quanto já vinha sendo implantado a partir da Lei $\mathrm{n}^{\mathrm{o}}$. 6.938/81, prestigiando o sistema de comando e controle, complementado pela teoria da responsabilidade tríplice, adotado, para a esfera civil, a modalidade objetiva.

O conceito da defesa e preservação do meio ambiente como vetor da implementação do direito ao meio ambiente ecologicamente equilibrado consta ainda de outros dispositivos constitucionais. O principal, e que concentra o ponto de partida para o tema deste trabalho, consta do artigo 170, VI, da CF.

Inserto no Capítulo I do Título VII da CF, cuida o artigo 170 de trazer os princípios gerais da atividade econômica, declarando que a ordem econômica funda-se na valorização do trabalho humano e a livre iniciativa, e tem por fim assegurar a todos existência digna, dados os ditames da justiça social, e observados os princípios de que tratam seus incisos, dos quais destaca-se aqui o VI, na redação original, conforme posta no texto constitucional promulgado em 5 de outubro de 1988:

VI - defesa do meio ambiente;

Tal dispositivo, por força de alteração trazida pela Emenda Constitucional $n^{\circ}$. 42/2003, passou a contar com a seguinte redação:

VI - defesa do meio ambiente, inclusive mediante tratamento diferenciado conforme o impacto ambiental dos produtos e serviços e de seus processos de elaboração e prestação;

A alteração trazida pela Emenda Constitucional, a ser vista em mais vagar adiante, representa uma inovação fundamental, que permite ao legislador complementar, conforme se verá em capítulo próprio deste trabalho, o sistema de comando e controle inaugurado para a defesa e preservação do meio ambiente em 1981, quando da entrada em vigor da Lei ${ }^{\circ}$. 6.938/81. A forma de implementação dessa faculdade/dever concedida ao legislador infraconstitucional é que constituirá a parte principal deste trabalho, com a proposta que formularemos atrelada a duas variáveis fundamentais do combate à questão climática para efeitos das emissões de Gases de Efeito Estufa - GEE no Brasil: política energética e florestas. 
Vem bem a propósito o ensinamento de Ricardo Carneiro ${ }^{35}$, que trata de maneira clara da integração entre o quanto estatuído nos artigos 225 e 170 da Constituição Federal, e considerada a Lei $n^{\circ}$. 6.938/81:

Desse modo, de acordo com os discursos constitucional e infraconstitucional, a atividade econômica no Brasil deve conciliar-se com a necessidade de garantia de seu processo de continuidade, através da preservação dos recursos ambientais, havendo a clara indicação de que os padrões de desenvolvimento econômico juridicamente desejados são aqueles que satisfaçam aos critérios de preservação de nosso patrimônio ambiental natural. Assim, os modelos insustentáveis, que não se adéquam aos pressupostos da preservação do meio ambiente, não são considerados em nosso sistema como verdadeiros modelos de desenvolvimento.

O marco constitucional, construído pela conjugação entre os artigos 170 e 225 do texto magno, não deixa dúvida quanto à necessidade de integração entre dois valores: crescimento econômico, pelo modo capitalista de produção, e adequação desse processo à utilização racional, voltada à preservação de sua natureza intergeracional, dos recursos naturais.

\section{- conclusão parcial do ponto}

Este portanto o contexto de abordagem da questão ambiental pelo texto constitucional: no que toca à disciplina do ponto, em si, prestigia-se o sistema que já antes havia sido instaurado pela Lei $\mathrm{n}^{\mathrm{o}}$. 6.938/81, fundado no comando e controle. De outra banda, quando se trata da inserção da variável ambiental na ordem econômica, trouxe a $\mathrm{CF}$, de ordem inicial, a vinculação da defesa do meio ambiente como princípio, para depois acrescentar à disciplina a faculdade, conferida ao legislador infraconstitucional, de efetivar tal defesa do meio ambiente e, mais especificamente, do bem ambiental, por meio da concessão de tratamento diferenciado a serviços e produtos cujo processo de elaboração e prestação sejam diferenciados do ponto de vista de seu impacto ambiental.

O trato da questão ambiental, diante da visão antropocêntrica impressa no texto constitucional, demanda que, sem inviabilizar o crescimento econômico, e a produção pelo modelo capitalista, se faça uso racional dos recursos naturais, de forma que se garanta sua

\footnotetext{
${ }^{35}$ CARNEIRO, Ricardo. Direito ambiental: uma abordagem econômica. Rio de Janeiro: Forense, 2003. p. 100.
} 
preservação para as futuras gerações. O modelo de desenvolvimento - ou crescimento econômico e social - vincula-se à preservação ambiental.

\section{(2) exame crítico: os eventos históricos, os 30 anos de aplicação e a constatação da saturação do sistema}

Estabelecida a Política Nacional do Meio Ambiente, e observado o período desde então decorrido, a constatação inescapável é a de que, após o grande avanço inicial, natural pela inserção de um sistema de comando e controle onde antes nada havia, deixou o sistema de avançar em termos de eficiência e resultados.

A melhor compreensão desse cenário, compreendido no período entre 1981 (entrada em vigor da Lei $\mathrm{n}^{\circ}$. 6.938/81) e o momento atual (final de 2010), impõe sua divisão em espaços temporais delimitados pelas demandas enfrentadas pelo Poder Público e a sociedade no trato da questão ambiental. Tais espaços, a seguir comentados, seriam os seguintes:

- Da entrada em vigor da Lei ${ }^{\circ}$. 6.938/81 até o estabelecimento da Lei $\mathrm{n}^{\circ}$. 7.347, de 24.7.1985;

- De julho de 1985 até a inserção do $\S 6^{\circ}$ ao artigo $5^{\circ}$ da Lei no ${ }^{\circ}$ 7.347/85, ocorrido em 1990: o Termo de Ajustamento de Conduta - TAC e o resgate do passivo ambiental;

- Do TAC à responsabilidade penal, vinda efetivamente em 1998, com a Lei no ${ }^{\circ}$ 9.605, de 13.2.1998;

- A responsabilidade penal e seus efeitos sobre a questão ambiental; e

- O século XXI e a superação dos parâmetros legais de comando e controle como paradigma único ao trato da questão ambiental, e a efetiva inserção da questão climática.

Outros métodos de abordagem desse período poderiam ser adotados, tal como a localização espaço-temporal a partir da espécie de risco sob combate: a questão das emissões atmosféricas, tema central do início da década de 1980, seguida do enfrentamento da questão dos efluentes líquidos, já na década de 1990; a questão dos resíduos sólidos, ponto que assumiu especial grandeza já na primeira década deste século, e, paralelamente a esses marcos da atuação na defesa e preservação do meio ambiente, as questões correlatas, tais como ruídos, vibrações, organismos geneticamente modificados, abordagem a partir da 
questão das bacias hidrográficas, e tantos outros aspectos que, a seu tempo, marcaram - e ainda marcam - um momento de especial consideração.

A opção que fizemos pelos marcos legais se justifica, em nossa opinião, porquanto se tem, ali, datas claras, objetivas, para se passar de um momento a outro, com a inserção de uma nova ferramenta ao sistema de defesa e preservação ambiental. A consideração dos elementos e espécies de risco pode gerar debates quanto ao efetivo momento em que tal aspecto ganhou importância nos debates, o que poderia colocar em risco a credibilidade do método adotado.

Daí porque se adota, para fins deste trabalho, os marcos legais como pontos de determinação das fases verificadas, nesse período de cerca de trinta anos, em que a Lei $n^{\circ}$. 6.938/81 ofereceu, como linha mestra, o sistema de defesa e preservação ambiental que agora se analisa.

Cumpre destacar desde logo que, em paralelo ao exame desses períodos ou fases em que se dividem os trinta anos de vigência da Lei nº 6.938/81, cuidar-se-á aqui de examinar também a introdução, no pensamento do Direito Ambiental, de princípios novos, indutores de alterações nas relações entre Homem X meio ambiente e, por consequência, no trato da questão sob o prisma do Direito.

Passemos, pois, ao exame de cada uma das fases propostas:

\section{- Da entrada em vigor da Lei $n^{0}$. 6.938/81 até o estabelecimento da Lei $n^{0}$. 7.347, de}

\subsubsection{5}

Conforme já destacado alhures, a Lei $\mathrm{n}^{\circ}$. 6.938/81 estabeleceu em nosso ordenamento, em âmbito nacional, o controle das atividades degradadoras do meio ambiente, elegendo para tanto o sistema de comando e controle, complementado pela responsabilização dos infratores às regras então postas, assim como pela obrigação objetiva de reparação do dano ambiental ${ }^{36}$.

Ao tratar da questão do estabelecimento da Política Nacional do Meio Ambiente,

\footnotetext{
${ }^{36}$ Aqui são dois os princípios fundamentais inseridos: de um lado, o princípio da prevenção, que orienta a adoção de medidas disponíveis para evitar e prevenir o risco ambiental, e, de outro lado, o princípio da reparação, que orienta a tese de que as externalidades negativas não prevenidas e evitadas da atividade de risco deverão ser internalizadas, ainda que sob o foco reparatório, quando materializadas.
} 
pela Lei $n^{\circ}$. 6.938/81, Edis Milaré ${ }^{37}$ destaca que esse perfil, de intervenção do Estado na economia, para impor regras ao exercício da atividade produtiva, e sanções aos desencaminhados, era imperioso, porque ali se quebrava o paradigma da falta de controle, para se estabelecer a atuação forte do Estado na limitação da liberdade de produzir, retirando-lhe a prerrogativa de fazê-lo à custa do meio ambiente:

A superação desse quadro de degradação e desconsideração ambiental passa, necessariamente, por alterações profundas na compreensão e conduta humanas. É um avanço que pode ser conseguido, em primeiro lugar, através de adequada educação ambiental, nas escolas e fora delas. Em segundo lugar, exige a criação (e implementação) de instrumentos legais apropriados, dado que, no embate dos interesses econômicos, só o Poder Público é capaz de conter, com leis coercitivas e imposições oficiais, a prepotência dos poderosos (poluidores e degradadores, no nosso caso), pois, "onde há fortes e fracos, a liberdade escraviza, a lei é que liberta".

A inovação, no entanto, já vinha sendo implementada nos Estados do Rio de Janeiro e de São Paulo, nos quais, em 1975 e 1976, respectivamente, já haviam sido criadas e aprovadas políticas estaduais de meio ambiente, sob as quais se adotou o sistema de licenciamento ambiental como mote central. Vale dizer, os dois estados da Federação com maior índice de industrialização já contavam, em 1981, com um sistema próprio de controle das atividades passíveis de degradar o meio ambiente.

Tal fato contribuiu muito para que, a quem examinasse o parque industrial nacional, logo após a entrada em vigor da Lei $n^{\circ}$. 6.938/81, parecesse ter havido forte adesão ao sistema ali proposto, com destaque para os estados de São Paulo e Rio de Janeiro, justamente os dois entes da Federação com maior concentração de nosso parque industrial.

Nos demais estados da Federação, aos poucos, surgiram políticas próprias de meio ambiente, todas elas sempre calcadas no licenciamento ambiental como vetor principal. E, com isso, o que se viu foi, paulatinamente, a disseminação do licenciamento ambiental como uma realidade de nossa indústria.

Havia ali, naquela primeira fase, no entanto, uma fragilidade que retirava ao sistema capacidade de imposição de suas regras. Com efeito, ainda que estruturado sob a premissa do controle prévio do Estado, materializado pelo licenciamento ambiental,

\footnotetext{
${ }^{37}$ MILARÉ, Edis. op. cit.
} 
seguido da fiscalização do atendimento às regras e parâmetros fixados para a regular operação dos empreendimentos sujeitos ao licenciamento, ainda assim o sistema mostravase frágil, dada a ineficiência de sua face de repressão.

Isto porque, quando verificado o dano ao meio ambiente, na forma do artigo $14, \S$ $1^{\circ}$, da Lei $n^{\circ}$. 6.938/81, impor-se-ia ao causador do dano a reparação ou indenização do dano causado ao meio ambiente e a terceiros. No entanto, nosso sistema processual não dispunha de um mecanismo que permitisse a agilidade necessária, em Juízo, à discussão do dano ambiental e da necessidade de sua reparação.

Ora, dada a natureza do dano ao meio ambiente, dispensa explicações o fato de que, quanto maior a demora em se buscar sua reparação, maior a possibilidade de se tornar irreversível o dano.

Nesse contexto, ainda que o sistema posto pela Lei $\mathrm{n}^{\circ}$. 6.938/81 previsse, como consequência ao dano ambiental, a obrigação de reparação civil, pela modalidade objetiva de responsabilidade, tornava-se temerária a ida ao Judiciário para se invocar tal obrigação por parte do causador do dano, uma vez que, para adequada instrução do processo, e superação de todas as suas fases, até se chegar à maturidade processual para a decisão, o dano provavelmente ter-se-ia já tornado irreversível. Inócua, pois, em vários casos, seria a medida - o remédio - previsto em lei para garantir a imediata reparação - ou indenização, apenas quando impossível esta - do dano ambiental.

Nesse contexto é que, em paralelo à maciça inserção do setor produtivo industrial no âmbito do licenciamento ambiental, vivia-se naquele período um forte risco de naufragar a proposta de, adicionalmente ao controle administrativo da atividade de risco, ter-se garantida a reparação do dano, quando não evitado este.

Daí porque, visando a controlar este risco, veio ao sistema, em 1985, a Lei ${ }^{\circ}$. 7.347, de 24.7.1985, por meio da qual se estabeleceu rito processual próprio, a ação civil pública, para as demandas judiciais em que, entre outras, se busque a reparação do dano ambiental (artigo $1^{\circ}, \mathrm{I}$ ), de espeque moral e material, conforme redação determinada pela Lei $n^{\circ} .8 .884 / 94$.

Assim, o que se viu desde que criado o sistema, por meio da Lei $\mathrm{n}^{\circ}$. 6.938/81, e até que vigente a Lei $n^{\circ}$. $7.347 / 85$, foi um período de adequação de nosso parque industrial à exigência do licenciamento ambiental como pressuposto ao exercício de atividades 
potencialmente degradadoras do meio ambiente, sem que se tivesse, no entanto, eficiente resposta aos danos ambientais efetivamente causados.

\section{- De julho de 1985 até a inserção do $§ 6^{\circ}$ ao artigo $5^{\circ}$ da Lei $n^{\circ}$. 7.347/85, ocorrido em} 1990: o Termo de Ajustamento de Conduta - TAC e o resgate do passivo ambiental

Com a edição da Lei $n^{\circ}$. 7.347/85 uma nova fase teve início no controle das atividades degradadoras do meio ambiente no Brasil.

Isso porque, em adição ao controle de âmbito administrativo, realizado por meio do licenciamento ambiental, passou a ser utilizada a ferramenta da ação civil pública como elemento de resposta e repressão ao dano ambiental, com sua reparação como mote central.

Para que se tenha noção da força e expectativa com que recebida pelo sistema a ação civil pública, basta destacar que, exatos sete dias após publicada a Lei $\mathrm{n}^{\circ}$. 7.347/85, foi proposta ação civil pública de vulto, na Comarca de Cubatão, contra as empresas que então compunham o polo petroquímico daquela cidade. $\mathrm{O}$ autor da ação, o Ministério Público do Estado de São Paulo, então representado por ninguém menos que Edis Milaré, e a Oikos, entidade do terceiro setor então presidida pelo não menos importante Fábio Feldmann, buscavam por meio da demanda impor às empresas do polo petroquímico de Cubatão a recomposição da vegetação da encosta da Serra do Mar, que, nos dizeres dos autores, houvera sido danificada pelas emissões atmosféricas geradas pelos réus.

Esta demanda, emblemática, bem demonstra o quão bem-vinda foi, para complementação do sistema, a ação civil pública. O controle administrativo exercido pelo Estado, por meio do licenciamento ambiental e fiscalização de seu cumprimento, não cobria a lacuna da ineficiência dos sistemas processuais para a ação judicial de imposição da obrigação de reparar o dano ambiental, e a ação civil pública veio, ao menos em um primeiro momento, impor-se como uma ferramenta adequada à execução forçada dessa obrigação reparatória.

A Lei $n^{\circ}$. 7.347/85, no entanto, foi além, e inovou, mais uma vez, na busca de aprimorar o sistema. Por meio de seu artigo $8^{\circ}, \S 1^{\circ}$, criou a figura do inquérito civil, procedimento de ordem administrativa, interno e exclusivo ao Ministério Público, cujo objetivo único é o de reunir informações bastantes à decisão, pelo representante do 
Parquet, quanto ao cabimento e necessidade - ou não - da propositura da ação civil pública. Por outras palavras, concedeu-se ao Ministério Público poder de requisição para que, em investigação prévia, verifique a existência ou não do dano ambiental, para que, se verificado este, promova a ação civil pública.

Com essa nova ferramenta em mãos, e estando já caminhando em ritmo satisfatório a submissão da indústria brasileira ao licenciamento ambiental, passou a sociedade primordialmente pela ação do Ministério Público - a buscar a reparação dos danos ambientais, em demandas como a invocada acima a título de exemplo.

Ocorre, porém, que se verificou que, reunidos pelo Ministério Público, em sede investigativa, dados suficientes à caracterização do dano ambiental, dois gargalos se revelavam ao sistema: de um lado, mesmo com a ação civil pública, o lapso temporal que necessariamente decorreria entre propositura do feito e decisão de mérito, via de regra, tornaria irreparável o dano causado; e, de outro lado, inúmeras situações verificaram-se nas quais, uma vez reunidos os dados da ocorrência do dano e de seu nexo causal com certa atividade, teria o causador do dano, se assim lhe fosse facultado, buscado a reparação do dano em sede extrajudicial, evitando assim o desgaste e a exposição da ação civil pública.

Por força da natureza difusa do meio ambiente como bem jurídico, não poderia o Ministério Público, salvo expressa previsão legal, abrir mão da propositura da ação civil pública, nem tampouco transigir, na acepção jurídica do termo, diante de um bem do qual não seria titular, mas apenas estaria a defender em favor da coletividade.

A judicialização da questão do dano ambiental, certamente, a ninguém interessava. E, nesse contexto, a ferramenta processual criada para viabilizar a repressão ao dano ambiental revelava risco de ineficiência, nos casos em que a pretensão de reparação do dano restasse não resistida pelo ofensor. O sistema clamava por uma saída híbrida, que viabilizasse a ação de repressão ao dano, na esfera civil, sem as mazelas do processo.

A solução, de felicidade rara, veio em 1990, por meio do artigo 113 do Código do Consumidor (Lei $\mathrm{n}^{\circ}$. 8.078, de 11.9.1990), que acrescentou o parágrafo $6^{\circ}$ ao artigo $5^{\circ}$ da Lei $\mathrm{n}^{\circ}$. 7.347/85, nos seguintes termos:

$\S 6^{\circ}$ Os órgãos públicos legitimados poderão tomar dos interessados compromisso de ajustamento de sua conduta às exigências legais, mediante cominações, que terá eficácia de título executivo extrajudicial. 
Não poderia ser mais feliz a solução encontrada pelo legislador. Diante da situação então vigente, em que o único caminho possível era a propositura da ação civil pública, com a indesejada submissão da questão do dano ambiental, sempre, ao Judiciário, sem a oportunidade de se poder recorrer à composição, a criação da figura do compromisso de ajustamento de conduta significou, conforme feliz manifestação de Edis Milaré, a possibilidade de "resgate do passivo ambiental".

Assim é que, com a vinda desse novo instituto ao sistema, estabeleceram-se as condições para superar-se o período segundo, de submissão do dano ambiental, sempre, ao Judiciário, para se ter sua repressão e reparação.

\section{- Do Termo de Ajustamento de Conduta - TAC à responsabilidade penal, vinda efetivamente em 1998, com a Lei $\mathbf{n}^{\circ}$. 9.605, de 13.2.1998}

Com o estabelecimento da possibilidade do ajustamento de conduta, formalizado em termo próprio, por parte do causador do dano ambiental, inaugurou-se uma nova - a terceira - fase no controle das atividades degradadoras do meio ambiente. Quando, apesar do controle exercido por meio do licenciamento e fiscalização ambiental, ainda assim houver a ocorrência do dano, e uma vez reunidos os elementos indicativos da efetiva existência desse dano, e do nexo de causalidade com uma determinada atividade, passam os órgãos públicos legitimados à propositura da ação civil pública voltada à reparação desse dano a uma fase intermediária, prévia a tal ato, na qual se oferta ao causador do dano a oportunidade de sua reparação voluntária, por meio da assunção de responsabilidade a tanto, e definição, em Termo de Ajustamento de Conduta - TAC, das medidas a serem adotadas para tal reparação.

A oportunidade de se evitar o desgaste e exposição negativos da ação civil pública, somados à possibilidade de se negociar o estabelecimento das medidas de reparação a serem adotadas, bem como o prazo e custo/desembolso voltados a tanto, exerceram grande atrativo ao setor produtivo, nos primeiros anos de vigência do instituto.

Assim é que, com a instituição do TAC como elemento de composição do sistema de comando e controle + reparação objetiva do dano, iniciou-se nova fase na administração do risco ambiental no Brasil. 
Muitas foram as ações civis públicas evitadas ou extintas por meio da formalização de TACs. Dados do Ministério Público do Estado de São Paulo revelam números excepcionais, na década de 1990, de inquéritos civis e procedimentos investigatórios que redundaram na formalização de TACs.

Em adição aos TACs formalizados em atuação direta do Ministério Público, termos de compromisso outros passaram a ser formalizados junto aos órgãos de controle e fiscalização ambiental, possibilitando assim que empresas antes em situação irregular perante tais entes, notadamente no que toca ao licenciamento ambiental, passassem a uma situação de regularidade, corrigindo e ajustando sua conduta.

A ferramenta do ajustamento de conduta revelou-se, pois, eficaz instrumento de gestão ambiental, que possibilitou a harmonização, sem a necessidade de se recorrer ao Judiciário, de um sem-número de situações antes de irregularidade.

Alterar-se-ia esse estado de coisas, no entanto, com a entrada em vigor da Lei $\mathrm{n}^{\circ}$. 9.605, de 13.2.1998, por meio da qual, a par de se alterar a disciplina da responsabilidade administrativa em matéria ambiental, se definiu os tipos penais específicos aplicáveis à matéria.

\section{- a responsabilidade penal e seus efeitos sobre a questão ambiental}

A Lei $n^{\circ}$. 6.938/81 já trouxe, em seu artigo $14, \S 1^{\circ}$, a indicação de que caberia a responsabilização penal do agente causador de danos ambientais (O Ministério Público da União e dos Estados terá legitimidade para propor ação de responsabilidade civil e criminal, por danos causados ao meio ambiente).

Não havia, porém, a tipificação do que seria o crime de danos ao meio ambiente, de sorte que a previsão legal em questão restou sem qualquer aplicação.

Para sanar tal lacuna, alterou-se em 1989 o texto do artigo 15 da Lei nº. 6.938/81, que passou a ter a seguinte redação:

Art. $15 \mathrm{O}$ poluidor que expuser a perigo a incolumidade humana, animal ou vegetal, ou estiver tornando mais grave situação de perigo existente, fica sujeito à pena de reclusão de 1 (um) a 3 (três) anos e multa de 100 (cem) a 1.000 (mil) MVR. (conforme redação dada pela Lei nº ${ }^{\circ}$.804/89). 
A tentativa de definir a conduta tipificadora do crime "ambiental", todavia, não alcançou sucesso, porquanto criou-se, ali, um tipo penal extremamente amplo, aberto, de dificílima caracterização. Entre as críticas então postas ao texto normativo destacou-se a muito pertinente afirmação de que, na forma como redigido, o dispositivo admitiria classificar como crime "ambiental” praticamente qualquer conduta humana.

Seja por conta desse perfil demasiadamente aberto do texto legal, seja por qualquer outra razão, o fato é que ainda não se teve, como decorrência da nova redação da lei, responsabilização penal em matéria ambiental, ainda que, como já estava em vigor em 1989 a Constituição Federal, quando do estabelecimento do texto da lei, já vigorasse em nosso sistema a possibilidade de imputação de crime à pessoa jurídica (conforme previsão expressa trazida pelo $\S 3^{\circ}$ do artigo 225 da $\mathrm{CF}$ ).

A efetiva aplicação da responsabilidade penal em matéria ambiental somente veio a efetivar-se a partir da publicação da Lei $n^{\circ}$. 9.605/98, quando foram então especificadas, em detalhe, as condutas tipificadoras dos crimes contra o meio ambiente.

Naturalmente, foi ruidosa a reação à lei, tanto para se elevarem vozes em dizer que não faria senso criminalizar determinadas condutas, como para contestar, em termos gerais, a imputação de responsabilidade penal em matéria ambiental, além de reclamos outros, como, por exemplo, o de que não se poderia dar efetiva aplicação à responsabilidade penal da pessoa jurídica, posto que ausente o elemento volitivo.

Alguns pontos, que não estes, merecem aqui que nos detenhamos, porque conexos ao ponto de interesse desse exame histórico, e balizadores da conclusão que mais adiante se defenderá como correta: (a) de um lado, os efeitos da tipificação das condutas sujeitas à responsabilidade penal ambiental sobre a efetividade e viabilidade de instrumento outro do sistema, o TAC; e (b) mais importante, a medida de transição inserida na Lei nº. 9.605/98, sintomática do estado de coisas vivido na realidade da gestão do risco ambiental no país.

No que toca aos efeitos da tipificação das condutas sujeitas à responsabilidade penal ambiental sobre a efetividade e viabilidade do TAC, o que se verificou foi que, em termos práticos, vários agentes que buscariam o TAC como instrumento de harmonização de sua conduta, diante do risco ambiental das atividades que desenvolvem, deixaram de fazê-lo, sob raciocínio simples e cartesiano de que, admitida a conduta irregular como requisito ao TAC, e tipificada tal conduta como criminosa, serviria o TAC, por via direta, 
como confissão do crime contra o meio ambiente, sujeitando assim o agente que buscava regularizar sua conduta, sob as óticas administrativa e civil, às sanções de ordem penal.

Com efeito, tipificada a falta de licença ambiental, por exemplo, como crime (artigo 60 da Lei $n^{\circ}$. 6.938/81), ou ainda tipificado como crime o ato de causar poluição (artigo 54 da lei), o só fato de se formalizar TAC para regularização de licenciamento ambiental, ou ainda para correção de emissões poluentes irregulares já caracterizaria a confissão dos crimes previstos para tais hipóteses.

O resultado imediato, portanto, foi o pior possível, pois ao invés de induzir correção de condutas e evitar condutas irregulares, a definição das condutas tipificadoras dos crimes contra o meio ambiente levou os agentes em tal situação a evitarem a regularização de suas condutas por meio do TAC. Não só não se teve o efeito preventivo pretendido pela Lei, como se afetou o "resgate do passivo ambiental" a que se referiu Edis Milaré.

Em adição, e em resposta à reação negativa à Lei $n^{\circ}$. 9.605/98, entendeu o legislador de, por meio da Medida Provisória - MP nº 1.710, de 8.7.1998 (reeditada e depois substituída pela MP $n^{\circ}$. 2.163-41/2001), inserir, nas disposições finais desse Diploma, o artigo 79-A, que assim dispôs:

Art. 79-A. Para o cumprimento do disposto nesta Lei, os órgãos ambientais integrantes do SISNAMA, responsáveis pela execução de programas e projetos e pelo controle e fiscalização dos estabelecimentos e das atividades suscetíveis de degradarem a qualidade ambiental, ficam autorizados a celebrar, com força de título executivo extrajudicial, termo de compromisso com pessoas físicas ou jurídicas responsáveis pela construção, instalação, ampliação e funcionamento de estabelecimentos e atividades utilizadores de recursos ambientais, considerados efetiva ou potencialmente poluidores.

\section{(...)}

$\S 2^{0}$ No tocante aos empreendimentos em curso até o dia 30 de março de 1998, envolvendo construção, instalação, ampliação e funcionamento de estabelecimentos e atividades utilizadores de recursos ambientais, considerados efetiva ou potencialmente poluidores, a assinatura do termo de compromisso deverá ser requerida pelas pessoas físicas e jurídicas interessadas, até o dia 31 de dezembro de 1998, mediante requerimento escrito protocolizado junto aos órgãos competentes do SISNAMA, devendo ser firmado pelo dirigente máximo do estabelecimento.

A inserção desse artigo 79-A no texto da lei, por Medida Provisória, seis meses após a publicação do texto original da lei, revela um aspecto de fundamental interesse para 
a análise de ordem histórica que aqui se faz acerca dos praticamente 30 anos de vigência do sistema de comando e controle, materializado primordialmente pelo licenciamento ambiental. Isto porque tal fato deu-se exclusivamente porque, diante do risco de penalização criminal (em adição ao risco de penalização administrativa, que já vigorava, na forma do artigo 14 , caput, da Lei $\mathrm{n}^{\circ}$. 6.938/81, mas que assumiu valores de apenamento substancialmente maiores, com a Lei $\mathrm{n}^{\circ}$ 9.605/98) pela falta de licenciamento ambiental, ergueram-se vozes na sociedade clamando por um prazo para regularização, antes de se ter efetivada a aplicação do quanto disposto pela Lei nº. 9.605/98.

Ora, tal fato revela uma realidade única: apesar de se terem então passado mais de 26 anos de vigência da Lei $n^{\circ}$. 6.938/81, o parque industrial brasileiro apresentava sérias falhas em seu licenciamento ambiental. Não fosse dessa forma, não se teria presenciado tão raivosa reação ao aumento dos valores das multas administrativas incidentes em caso de irregularidade em tal quesito, nem tampouco à tipificação de tal fato como crime.

Mais ainda, reforça o quanto aqui sustentado a reação do setor produtivo brasileiro, de renegar o TAC, por força da edição da Lei $n^{\circ}$. 9.605/98, para evitar a confissão de conduta criminosa.

Duas conclusões necessariamente decorrem desta constatação: a uma, e no que toca a este subitem específico deste trabalho, verifica-se que a inserção da Lei nº . 9.605/98 no sistema trouxe, em uma primeira reação, não sua acomodação e integração, mas sua rejeição e, por consequência, a rejeição de instrumento outro, de ordem administrativa e civil que, até então, era festejado por uma das maiores autoridades de nosso Direito Ambiental como uma ferramenta de "resgate do passivo ambiental" de nosso setor produtivo.

A outra conclusão é a de que, dada a reação havida, o sistema como um todo, calcado no licenciamento ambiental como ferramenta central, revelava-se falho e ineficiente. A dimensão da reação verificada é diretamente proporcional, necessariamente, ao contingente de atividades e empreendimentos que, até então, ainda não se tinham submetido ao licenciamento ambiental, maculando, enfraquecendo, colocando em risco e tornando de todo ineficiente o sistema que, ali, já contava com mais de 26 anos de aplicação. 
Este último aspecto, especificamente, toca à conclusão deste capítulo, e será mais detalhadamente explorado adiante.

\section{- Conclusão parcial do ponto: o sistema saturado, e as iniciativas recentes de complementação - postura diante da questão}

O sistema estabelecido para a efetivação da defesa e preservação ambiental a que se refere o artigo 225 da Constituição Federal funda-se, de forma central, no licenciamento ambiental, tornado instrumento de política pública nacional por meio da Lei ${ }^{\circ}$. 6.938/81. O licenciamento ambiental, instrumento típico de Estados intervencionistas, é em nosso sistema complementado pela imputação de responsabilidade administrativa e penal, assim como pela responsabilização pela modalidade objetiva daquele que causar danos ao meio ambiente e a terceiros.

Ao longo desses quase trinta anos decorridos desde a publicação da Lei $n^{\circ}$. 6.938/81, ainda que avanços tenham sido alcançados, com a sujeição de parcela significativa dos empreendimentos ao controle, pelo Poder Público, por meio do licenciamento e fiscalização ambiental, é indiscutível que ainda não se chegou a uma condição ideal, de absoluto controle das atividades de risco ambiental pelo Estado.

Demais disso, parecem esgotadas as medidas de possível implementação para otimização desse sistema. A responsabilidade nas esferas administrativa, civil e penal encontra-se regulamentada, e as políticas de ordem federal e estaduais mostram-se estruturadas no que toca às ferramentas de comando e controle direto, ou seja, aquelas que regulam e orientam a fiscalização e apenamento das atividades de risco ambiental.

Nesse contexto, não é equivocado dizer que há um esgotamento do sistema, sem que se tenha chegado aos resultados ideais almejados quando de sua criação. Já tivemos a oportunidade de defender esse entendimento:

A evolução das discussões e instrumentos voltados à proteção ambiental demonstram que a adoção do sistema clássico, de imposição de condutas ou obrigações de não fazer ou agir, sob pena de incidência de sanções, revelou-se ao longo dos anos de alcance e de resultados não plenamente satisfatórios. ${ }^{38}$

\footnotetext{
${ }^{38}$ GRAU NETO, Werner. O Protocolo de Quioto e o Mecanismo de Desenvolvimento Limpo - MDL: uma análise crítica do instituto. São Paulo: Fiúza, 2006. p. 88.
} 
No mesmo sentido, Bessa Antunes ${ }^{39}$, ao cuidar da questão da repressão aos danos ambientais, pela aplicação da responsabilidade civil:

Como conclusão é possível afirmar que existe uma tendência moderna em adotar novos mecanismos para solucionar os danos ambientais. Tais mecanismos têm buscado, com frequência, superar as limitações que são inerentes à responsabilidade civil.

Importa, neste passo, examinar-se a caracterização desse sistema, para que se possa, mais adiante neste trabalho, propor outros instrumentos para a adequação total das atividades de risco ambiental aos objetivos da sociedade (que, ver-se-á também mais além, já não são os mesmos almejados quando da inserção do sistema de comando e controle, em 1981).

O sistema de comando e controle, materializado no licenciamento ambiental, caracteriza-se por ser (i) um mecanismo de ordem preventiva; (ii) de intervenção no exercício da atividade econômica lícita, regulando-a; (iii) de aplicação na esfera administrativa, (iv) pelo Poder Executivo; e (v) de execução forçada, quando desobedecido, por meio de imposição de sanções de ordem administrativa.

Assim, diante do esgotamento das medidas disponíveis para fazer valer e tentar tornar mais eficaz o sistema de comando e controle, eventual proposta de novos instrumentos de defesa e preservação do meio ambiente deverão tomar em conta orientação diversa, buscando-se, como ponto de partida, outros princípios orientadores do direito ambiental, que não aqueles inseridos no sistema vigente, notadamente o da prevenção (e, por decorrência, o princípio da precaução, também invocado por parte da doutrina como orientador do nosso sistema vigente).

Tais princípios seriam, fundamentalmente, os seguintes: usuário-pagador, e protetor-recebedor, princípios já reconhecidos como orientadores do direito ambiental; e, mais recente, e ainda não consolidado na doutrina, o mecanismo do estímulo e desestímulo, como elemento de alcance da materialização do princípio da sustentabilidade.

Cabe aqui tratar-se do conceito e alcance desses princípios, para que tenha a exata noção, mais adiante neste trabalho, da proposta que se trará, e da significância de seu

\footnotetext{
${ }^{39}$ ANTUNES, Paulo de Bessa. Dano ambiental: uma abordagem conceitual. Rio de Janeiro: Lúmen Júris, 2002. p. 312.
} 
mérito, de alteração do paradigma de abordagem da função da ferramenta tributária diante da necessidade de busca da sustentabilidade.

Para que se realize essa breve análise, necessário partir-se do conceito primeiro, o princípio que de início se adotou como vetor de estabelecimento de regras: o princípio do poluidor-pagador. Inserido na Declaração do Rio de Janeiro sobre Meio Ambiente e Desenvolvimento, o princípio do poluidor-pagador preconiza que aquele que se apropria de recursos naturais, degradando-os, modificando-os ou meramente transformando-os, deve internalizar os custos decorrentes dessa degradação, transformação ou modificação. O vetor de consideração do princípio, portanto, é o resultado negativo - a externalidade negativa - derivado da apropriação dos recursos naturais pelo empreendedor.

Veja-se que, do ponto de vista filosófico, não se está aqui regulando o acesso aos recursos naturais como uma forma de se obter sua preservação, proteção ou controle. $O$ que se está a fazer é meramente tratar do efeito negativo da apropriação, que não é em si questionada. O recurso natural continua, pois, nessa fase, a ser tratado como se fosse inserido na equação de produção econômica sob custo zero, assumindo efeitos sobre tal equação apenas como uma derivação, posto que sua apropriação traz o efeito colateral da geração de externalidades negativas. Delas é que trata o princípio.

Essas externalidades negativas ocorrem porque o mercado falha. Essa a concepção doutrinária, que sustenta que, da falha do mercado, resta a externalidade negativa não considerada no custo de produção, restando a partir disso não tratada, submetendo-se a

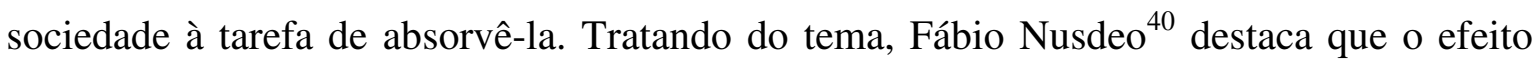
externo verifica-se quando o arcabouço legal não é capaz de identificar e atribuir custos adequadamente, falhando portanto em promover sua internalização.

Ocorre que, da evolução dos estudos acerca da questão do meio ambiente - e do bem ambiental - como item sujeito à tutela legal, passou-se a tratar do fato anterior à geração do efeito colateral (a externalidade negativa decorrente da apropriação do bem ambiental para inserção na equação de produção econômica), qual seja, a apropriação em si do bem ambiental pelo particular, retirando-o da condição de disponibilidade difusa, para tratá-lo como bem apropriado. O só uso do bem ambiental, nesta visão, passa a ser objeto de exame, independentemente das externalidades negativas que poderão defluir de sua apropriação - e que continuam gerando a obrigação de internalização dos custos correspondentes.

${ }^{40}$ NUSDEO, Fábio. op. cit., p. 375. 
Neste contexto é que surge o princípio do usuário-pagador, que vem se somar ao do poluidor-pagador, para dispor que o só uso do bem ambiental - ou do recurso natural funciona como fato gerador da obrigação de ressarcir a sociedade.

O exemplo que nos parece mais evidente, para o tema, é o do uso da água. Ora, bem difuso, de ordem ambiental, é a água que se encontra disponível nos rios. Ao apropriar-se da água, para inseri-la como parte de seu processo produtivo (seja para compor o produto final a ser produzido, seja para seu uso como elemento no processo, como, por exemplo, para uso em resfriamento), o particular retira a natureza difusa desse bem ambiental, dele beneficiando-se, e, em regra, com ele viabilizando sua produção econômica.

O princípio do usuário-pagador funda-se, pois, na premissa de que esse bem ambiental que é apropriado tem em si, intrinsecamente, valor econômico, que deve ser pago por aquele que dele se apropria na cadeia produtiva, como uma compensação à sociedade pelo fato de ser dela retirado tal bem, pela perda de sua natureza difusa.

Na definição de Henri Smets, citado por Consuelo Yoshida ${ }^{41}$, o princípio do usuário-pagador significa que o utilizador do recurso deve suportar o conjunto dos custos destinados a tornar possível a utilização do recurso e os custos advindos de sua própria utilização.

Os comitês de bacia hidrográfica, trazidos por força da Lei $\mathrm{n}^{\circ}$. 9.433, de 8.1.1997, materializam a aplicação do princípio do usuário-pagador: ente representativo da sociedade estabelece o valor a ser desembolsado pelo particular que se apropria do bem ambiental água.

O mecanismo de estímulo e desestímulo, por sua vez, constitui um instrumento de coordenação entre o dever de controle do Estado sobre o uso do bem ambiental (conforme estabelece o caput do artigo 225 da Constituição Federal - defendê-lo e preservá-lo para as presentes e futuras gerações) e o dever de regular a atividade econômica sob o princípio da defesa do meio ambiente, atribuindo tratamento diferenciado aos produtos e serviços cujo impacto ambiental seja reduzido dado o modo de produção ou de prestação adotados.

\footnotetext{
${ }^{41}$ YOSHIDA, Consuelo Yatsuda Moromizato. A efetividade e a eficiência ambiental dos instrumentos econômico-financeiros e tributários: ênfase na prevenção: a utilização econômica dos bens ambientais e suas implicações. In: TÔRRES, Heleno Taveira (Org.). Direito tributário ambiental. São Paulo: Malheiros Ed., 2005. p. 545.
} 
Tomados esses dois deveres do Estado, a atividade reguladora - e não interventora - do mercado passa necessariamente por (i) onerar as atividades cujo impacto ambiental - direto ou comparado - seja indesejado; e (ii) desonerar as atividades cujo impacto ambiental igualmente direto ou comparado - seja reduzido.

Não se trata aqui de abandonar ou conflitar com o sistema de comando e controle e sua principal ferramenta, o licenciamento ambiental. A tarefa de estabelecer a linha divisória entre atividades inviáveis sob a perspectiva ambiental, dados os impactos delas decorrentes, e as atividades viáveis sob tal perspectiva, é e deve continuar assinalada ao licenciamento ambiental. O papel do Estado regulador, aqui, não é de intervenção nessa dinâmica, mas de levar além a materialização da busca pela sustentabilidade, ao criar mecanismos que, alcançando a gama de diferentes tecnologias e métodos de exercício de uma determinada atividade, que sejam viáveis sob a aplicação do comando e controle, torne mais atraentes ao capital, ao investidor, aqueles cuja tecnologia e/ou método seja mais eficiente do ponto de vista da preservação dos recursos naturais e dos efeitos derivados do exercício da atividade produtiva - ou, por outras palavras, aqueles cujos impactos ambientais sejam os menores.

Essa perspectiva, de se trabalhar não no estabelecimento da régua divisória entre o que se pode e o que não se pode realizar, é que traz inovação e novo paradigma: deixa-se o controle da legalidade da atividade como índice de corte, para se acrescentar a essa exercício, que passa a ser prévio, variável adicional, de caráter totalmente fundado na busca da sustentabilidade.

Esses novos princípios e mecanismo, ao lado de sistemas como o do pagamento por serviços ambientais, é que possibilitam olhar-se para o sistema de proteção ambiental positivado em nosso país e pensar-se em novos instrumentos, que poderão - deverão - vir a completá-lo.

O que parece claro, qualquer que seja a vertente pretendida para complementação do sistema, é que não se pode dispensar tal conduta, sob pena de se ter um sistema saturado $^{42}$ e de eficiência restrita, que, se de um lado provou-se necessário e de reconhecidos resultados, ao longo de seus já trinta anos de aplicação, de outro lado mostra-

\footnotetext{
${ }^{42}$ Acerca da saturação - ou esgotamento - do modelo de comando e controle, vide artigo (GRAU NETO, Werner. Novos paradigmas sociais e econômicos do direito ambiental. In: BRAGA FILHO, Edson de Oliveira (Coord.). Sustentabilidade e cooperativismo: uma filosofia para o amanhã. Belo Horizonte: Ed. Fórum, 2011).
} 
se saturado, demandando a adoção de novas medidas para que seja complementado e atinja a plenitude dos objetivos constitucionais de defesa e preservação do meio ambiente.

- O século XXI e a superação dos parâmetros legais de comando e controle como paradigma único ao trato da questão ambiental, e a inserção da questão da sustentabilidade

Nos últimos anos, já com o reconhecimento do esgotamento do sistema de licenciamento ambiental como sistema de controle da atividade de risco ambiental, tem encontrado aplicação, ainda que em níveis aquém dos desejados, o princípio do usuáriopagador, acerca do qual acima se discorreu brevemente. A cobrança pelo uso da água é o exemplo mais vivo e polêmico de aplicação desse princípio em nosso sistema.

Mas a grande mudança na abordagem da questão ambiental, no cenário internacional e interno, nos últimos anos, toca ao papel do direito como ferramenta de controle da atividade de risco, tópico igualmente visitado em linhas gerais no item anterior.

Com efeito, o desenvolvimento e disseminação da noção de sustentabilidade retira ao direito, à legalidade de uma atividade de risco, a condição de objetivo, para torná-lo tão somente o primeiro de vários degraus a serem vencidos na busca por uma posição não mais de legalidade, mas, agora, de sustentabilidade.

Sustentabilidade, nos dizeres de Mario Monzoni e Silvia Llosa, seria não uma situação, um ponto a alcançar objetivamente, mas sim um processo que não encontra ponto final. Não existiria o "ser" sustentável, mas sim o "estar" momentaneamente, sob uma determinada perspectiva, sustentável, condição esta que se alteraria, tão logo identificada uma nova necessidade ou condição à qual a atividade de risco deva buscar adequar-se, para se manter em condição de sustentabilidade. Convém reproduzir a proposta de Monzoni e Llosa para o que seria sustentabilidade: avaliação do cumprimento das normas ambientais (tais como as normas de licenciamento ambiental), engajamento da sociedade e partes interessadas, consulta pública, transparência e avaliação de impactos ambientais, sociais e econômicos.

O Relatório Brundtland (1987), realizado a partir de mandato conferido no âmbito da ONU, e que teve elaboração capitaneada por Gro Harlem Brundtland, pontua que a 
sustentabilidade é um sistema que visa suprir as necessidades da geração presente sem afetar a habilidade das gerações futuras de suprir as suas.

Vários são os paradigmas quebrados pelo abandono do conceito da legalidade estrita como "teto", ou como objetivo a alcançar, no trato da questão do controle e harmonização da atividade de risco ambiental à vontade social, e com a adoção da sustentabilidade como objetivo.

O principal paradigma quebrado é o de se ter, como norte, uma situação estanque, refletida na letra fria da lei, representada, no imaginário, por uma linha, tal qual a linha do Equador, divisória entre duas situações claras: abaixo, estar-se-ia aquém da legalidade, na ilegalidade, portanto; e, acima, estar-se-ia na legalidade. Os parâmetros objetivos definidores dessa linha divisória entre "céu e inferno", postos em lei, têm necessariamente um grau considerável de objetividade (ter ou não ter a licença ambiental; atender ou não atender a determinados parâmetros de emissões poluentes).

Com a adoção do conceito de sustentabilidade como novo norte, o que se vê, de forma figurada, é a inversão da pirâmide de viabilidade de empreendimentos, para que se abandone o atendimento à lei como teto, passando-se a ter tal objetivo como "piso".

A análise de viabilidade de um determinado empreendimento, antes da adoção do conceito de sustentabilidade como vetor de orientação, partia da constatação da disponibilidade de recursos, para então verificar-se o potencial de mercado e de lucratividade do negócio pretendido, tomando-se então a questão logística como definidora de locação do empreendimento, para então, ao depois, verificar-se e ter-se como norte viabilizador o atendimento aos parâmetros legais incidentes sobre a atividade, tomada sua natureza e o local escolhido para sua implantação. Esse o modelo tradicional, resumidamente, de orientação para o desenvolvimento de atividades de risco.

Já sob o conceito da sustentabilidade, inverte-se a pirâmide, para que as análises econômicas e de mercado sejam preliminares, adotando-se ao depois, como passo primeiro (ou "piso"), e não mais patamar ou degrau último, as restrições de ordem legal aplicáveis, notadamente as ambientais, para, então, partir-se para a análise de sustentabilidade (ou de perfil reputacional e de inserção social) propriamente dita, examinando-se, tomado o local escolhido para a atividade, a inserção do empreendimento no meio comunitário local e as potenciais interações e riscos envolvidos, determinando-se as melhores formas de 
integração e harmonização dessas relações. O passo seguinte toca ao exame da interação do empreendimento com as demais partes interessadas, de forma a se identificar as restrições e opiniões acerca da atividade e de suas opções de localização, tecnologia, logística, etc., para que se possa, também aqui, buscar a melhor forma de integração e harmonização. Por fim, e em paralelo às demais medidas, busca-se obter informações acerca do modus operandi das empresas outras do mesmo setor e ramo de negócios, no que toca às suas relações com o meio ambiente e com a sociedade, de maneira a que se possa realizar exercício de benchmarking, adotando as melhores práticas como norte e requisito.

Da soma e revisão e reexame constantes desses critérios e cenários é que se encontrará uma postura de busca de sustentabilidade por parte do empreendimento.

Essa mudança de postura diante da questão dos requisitos para o exercício de atividades de risco traz consigo alguns efeitos ao empreendedor. De um lado, cria-se alguma insegurança, porquanto não se tem um norte fixo a alcançar para se poder afirmar regular e aceitável o exercício de determinada atividade. De outro lado, não se tem, por parte da sociedade, um instrumento cujo atendimento seja mandatório ao empreendedor. Se desatendida a lei, as sanções são claras, e pesadas.

Mas, se determinada atividade, em que pese atendendo aos parâmetros legais, não se revela sustentável, ou minimamente inserida no ciclo de busca da sustentabilidade, a ausência de caráter mandatório do atendimento a tais objetivos torna a imposição de sanções a tal atividade uma questão meramente de mercado. Por outras palavras, somente por meio de exercício do direito de não adquirir determinado produto é que poderá a sociedade impor a determinada empresa ou setor o atendimento a regras que, para além dos parâmetros legais, representam atendimento ao ciclo de sustentabilidade.

Nesse contexto, de inovações na forma de abordagem da relação entre atividade produtiva e sociedade e meio ambiente, é que se inserem os novos princípios do direito ambiental, e que se deve buscar propor novos instrumentos e mecanismos para que se possa trazer maior eficiência aos sistemas de controle das atividades de risco em nosso sistema.

O gargalo a superar, aqui, é o da institucionalização, ou do estabelecimento da estrutura necessária à busca da sustentabilidade. Se, de sua parte, o tema vem encontrando caminhos e conceituação no plano teórico; se, no seio da sociedade, mecanismos práticos 
de imposição de uma cultura de sustentabilidade ao meio produtivo se revelam a cada crise, a cada oportunidade nova; e se, como de fato é, o prestígio à sustentabilidade como norte a ser alcançado, é algo difundido e pacificado no plano das relações internacionais, é necessário reconhecer que a criação de estrutura e mecanismos legais para a materialização da busca desse estado, o de sustentabilidade, no plano interno às nações, e não difere aqui o Brasil, é algo ainda a superar.

Em 2005, na obra International Law and Policy of Sustainable Development, Duncan French ${ }^{43}$ chamava a atenção para o fato de que, em que pese desde 1992 reconhecido como um objetivo a alcançar, no plano internacional, a sustentabilidade ainda encontrava naquele momento - e pouco se alterou a situação de lá até hoje - resistência por parte dos países quando se verificava sua adoção como conceito - ou princípio - indutor da normatização interna. A tensão Norte-Sul, invocada para ilustrar as diferenças latentes entre países desenvolvidos e os em desenvolvimento, é fator relevante a impedir a disseminação, à larga e em escala interna, do conceito de sustentabilidade como elemento de indução normativa. Vale conferir a conclusão do capítulo da citada obra, em que o autor trata da política de desenvolvimento sustentável:

The endorsement of sustainable development by the international community in 1992 and the very clear reaffirmation in Johannesburg in 2002 undoubtedly indicates a high level of political commitment to the concept. Attention is now focusing upon the issue of implementation. It is recognition that sustainable development - to be meaningful - must result in practical change. It is not adequate to the international community simply to keep on recommitting itself to grand statements and political objectives; it must also show that it can implement them. However, it is equally clear that when confronted with the issue of implementation, the international community has yet to resolve many of the fundamental issues that surround sustainable development. The international community remains divided and uncertain as to how to operationalise a concept that is, behind the rhetoric, politically contentious. The tensions are numerous, but most controversial are those issues that persist between North and South.

O desafio, portanto, consiste em transportar o conceito de sustentabilidade, aceito e prestigiado no plano internacional, para a realidade normativa interna das nações que, como o Brasil, referendam o quanto formulado no âmbito internacional.

\footnotetext{
${ }^{43}$ FRENCH, Duncan. International law and policy of sustainable development. Juris Publishing, Manchester University Press, 2005.
} 


\section{- a questão do clima - o atendimento ao propósito constitucional e a internalização dos preceitos firmados no plano internacional}

Adicionalmente à mudança na forma de examinar as relações entre a atividade de risco e a sociedade, na busca da defesa e preservação do meio ambiente, insere-se no debate, e impõe-se como elemento de necessária consideração à viabilidade de qualquer atividade, a questão da mudança do clima.

Com efeito, não se pode falar em um mínimo de sustentabilidade, para qualquer empreendimento, sem que se tenha atendimento à necessidade de controle e combate à emissão de Gases de Efeito Estufa - GEE.

No plano jurídico, vincula-se o Brasil ao tema de forma sólida, a uma, no plano internacional, pelo fato de sermos parte signatária da Convenção-Quadro sobre Mudança do Clima, instrumento cujo objetivo central é o de conduzir os Estados-Parte à adoção de medidas, individuais ou conjuntas, que tenham como resultado a redução das emissões de GEE, assim como a mitigação de seus efeitos e a adaptação às transformações causadas pela mudança do clima.

Estabelecida no âmbito do Direito Internacional, e caracterizada como hard law ${ }^{44}$, a Convenção-Quadro sobre Mudança do Clima traz em seu corpo obrigações que o Brasil, ao firmá-los, demonstrou vocação em atender. Ocorre que, para que efetivamente se obrigue nossa nação a tais regras, estabelece o nosso sistema o requisito da ratificação dos textos internacionais em nosso meio interno. Fernando Rei e Kamyla Borges da Cunha ${ }^{45}$ destacam essa peculiaridade de nosso sistema:

Os mecanismos de recepção das normas de direito internacional no ordenamento jurídico brasileiro estão regulados principalmente pelas normas constitucionais e alinhados à jurisprudência ditada pelo Supremo Tribunal Federal, que não reconhece dispor a norma internacional de exequibilidade e operatividade imediatas no âmbito interno.

\footnotetext{
${ }^{44}$ A propósito do conceito de Hard Law e Soft Law, veja-se a obra de NASSER, Salem Hikmat. Fontes $e$ normas do direito internacional: um estudo sobre a soft law. São Paulo: Atlas, 2005.

${ }^{45}$ REI, Fernando; CUNHA, Kamyla Borges da. Cadernos NAE, Núcleo de Assuntos Estratégicos da Presidência da República, Brasília, n. 4, p. 313, abr. 2004.
} 
A manifestação da vontade do Estado em se submeter a um determinado instrumento firmado no âmbito do Direito Internacional apenas se completa, passando tal instrumento a surtir efeitos obrigacionais para o país, após cumprido o ritual posto em nosso sistema. Tal ritual se observa mediante (i) a aprovação do instrumento pelo Poder Legislativo, daí decorrendo sua publicação no âmbito interno, sob a forma positivada do Decreto Legislativo; (ii) por meio de ratificação do instrumento, pelo Presidente da República, a seu posterior depósito; e (iii) pela promulgação do instrumento pelo Presidente da República, por meio de Decreto Presidencial.

Somente após observado o trâmite de internalização do instrumento é que se terá sua aplicação no âmbito interno de nosso país. Antonio Paulo Cachapuz de Medeiros traça todo o relato histórico da formulação do texto constitucional vigente em nosso país para, arrimando-se em vasta doutrina, demonstrar que, pelo exercício interpretativo, se pode concluir que, apesar de aparentemente antinômicos, não o são os artigos 49, I, e 84, VIII, da Constituição Federal. Cachapuz ${ }^{46}$ destaca, após profunda análise do ponto:

À primeira vista, são contraditórios. Entretanto, se forem examinados atentamente, subtili animo, ver-se-á o nexo que os concilia.

Para a solução da antinomia aparente dos citados dispositivos, não pode ser utilizado o critério cronológico (ambos foram emitidos ao mesmo tempo); nem o critério hierárquico (ambos possuem a mesma hierarquia); nem o critério da especialidade (não se trata de conflito entre uma lei geral e outra especial, quando esta anula a primeira).

São normas constitucionais; logo, não se pode admitir a ab-rogação de qualquer delas, restando ao intérprete, assim, a alternativa de demonstrar que a incompatibilidade é aparente.

Do ponto de vista histórico-teleológico, a conclusão só pode ser que o legislador constituinte desejou estabelecer a obrigatoriedade do assentimento do Congresso para os tratados internacionais, dando ênfase para aqueles que acarretarem encargos, gravames, ônus financeiros, para o patrimônio nacional.

Do ponto de vista lógico-sistemático, há que considerar que os dispositivos em questão fazem parte do mesmo título da Constituição (Da Organização dos Poderes) e são como que as duas faces de uma mesma moeda: o artigo 84, VIII, confere ao Presidente da República o poder de celebrar tratados, convenções e atos internacionais, mas especifica que estão todos sujeitos a referendo do Congresso Nacional; o artigo 49, I, destaca que os tratados, acordos ou atos internacionais, assinados por quaisquer autoridades do Governo brasileiro, que acarretem encargos ou compromissos gravosos ao patrimônio nacional, precisam ser aprovados pelo Congresso.

\footnotetext{
${ }^{46}$ MEDEIROS, Antonio Paulo Cachapuz de. O poder de celebrar tratados: competência dos poderes constituídos para celebração de tratados à luz do direito internacional, do direito comparado e do direito constitucional brasileiro. Porto Alegre: Sergio Antonio Fabris Editor, 1995. p. 396-397.
} 
A incorporação da Convenção-Quadro sobre Mudança do Clima, em nosso meio, se deu em atendimento a preceitos constitucionais claros, que não dão margem a entendimento de que não estariam tais instrumentos internacionais em linha com nosso sistema.

De fato, no que toca à natureza de cooperação internacional por um objetivo comum, força motriz que informa a estrutura adotada na Convenção-Quadro e no Protocolo, nosso texto constitucional, já no preâmbulo, indica a vocação de nosso Estado para o atendimento à ordem interna e internacional, destacando a busca de solução pacífica para as controvérsias, o que, nos dizeres de José Cretella Junior ${ }^{47}$, constitui fundamento que, combinado com o princípio da "não intervenção", culminará com a política de cooperação internacional $^{48}$.

Não é por outra razão, senão em decorrência de tal ponto, que no artigo $4^{\circ}$, IX, do texto constitucional, insere-se a regra de que, em nossas relações internacionais, devemos nos pautar pela cooperação em busca do progresso da humanidade, observados também princípios outros, como o da independência e, principalmente, o da soberania política e econômica. Pinto Ferreira ${ }^{49}$, ao comentar o dispositivo, assim se manifesta:

As relações internacionais do País deverão consolidar-se nos princípios de independência, isto é, autêntica soberania política e econômica, e de autodeterminação dos povos, repudiando a intervenção direta ou indireta nos negócios políticos e econômicos de outros Estados.

Manoel Gonçalves Ferreira Filho ${ }^{50}$ destaca que o artigo $4^{\circ}$ da Constituição Federal revela-se ambíguo, assim comentando:

É visivelmente ambíguo este dispositivo constitucional que reflete inspirações nitidamente divergentes. Por um lado existe uma orientação nacionalista que se apega às ideias de independência nacional (item I), de não intervenção (item IV), de igualdade entre os Estados (item V). Por outro lado, há uma linha internacionalista que se traduz na ideia de que o Brasil nas suas relações internacionais deverá bater-se pela prevalência

\footnotetext{
${ }^{47}$ CRETELLA JUNIOR, José. Comentários à Constituição brasileira de 1988. 1. ed. Rio de Janeiro: Forense Universitária, 1989. v. 1, p. 176.

${ }^{48}$ A cooperação internacional constitui princípio que substituiu o princípio anterior, da coexistência pacífica, vigente até a Segunda Grande Guerra. Conforme destaca Celso D. de Albuquerque Mello, "Tudo começou com a descolonização que a Carta da ONU consagra e que tem a sua grande década nos anos 50." (MELLO, Celso D. de Albuquerque. Direito internacional econômico. Rio de Janeiro: Renovar, 1993. p. 19).

${ }^{49}$ FERREIRA, Pinto. Comentários à Constituição brasileira. São Paulo: Saraiva, 1990. v. 1, p. 49.

${ }^{50}$ FERREIRA FILHO, Manoel Gonçalves. Comentários à Constituição brasileira de 1988. São Paulo: Saraiva, 1990. v. 1, p. 21.
} 
dos direitos humanos (item II), da autodeterminação dos povos (item III) e do repúdio ao terrorismo e ao racismo (item VIII). Ademais, o texto também consagra a adesão a ideais sem dúvida de aplauso universal, como a defesa da paz (item VI) ou da solução pacífica dos conflitos (item VII) e o da concessão de asilo político (item X). O artigo $7^{\circ}$ da Constituição anterior era bem mais afirmativo do que este. Com efeito, ele proibia a guerra de conquista e impunha ao Brasil trabalhar, para que a solução dos conflitos internacionais se desse por meio de negociações, arbitragem e outros meios pacíficos, sempre com a cooperação dos organismos internacionais de que o Brasil participasse.

A dicotomia (ou ambiguidade, no termo mais forte utilizado pelo Professor Gonçalves Ferreira) acima citada, a nosso ver, pode ser reduzida e resumida ao aparente conflito entre o propósito da cooperação internacional e a observância da soberania ${ }^{51}$ política e econômica. De fato, o que se percebe do exame dos dispositivos postos no artigo $4^{\mathrm{o}}$ do texto constitucional é que, a despeito do impulso pela inserção do país no âmbito das relações internacionais amplas, já no conceito mais atual, da integração dos Estados diante de problemas comuns em seus efeitos (esfera na qual a questão ambiental, latu sensu, tem destaque), ainda se vê (e aqui não se trata de característica exclusiva à Constituição brasileira) fortes traços dos regramentos que se extrai da adoção do conceito da independência e da soberania econômica e política. Mas, bom destacar, não há aqui efetivo, mas apenas um aparente conflito. $\mathrm{O}$ respeito e apego à soberania, de fato, não ofende a busca, orientada pelo princípio da cooperação entre os povos, dos objetivos postos na Carta da ONU, base do que se denomina atualmente de Direito Internacional do Desenvolvimento. Celso D. de Albuquerque Mello ${ }^{52}$ explica que o DI do Desenvolvimento é norteado por dois princípios fundamentais, o da igualdade e o da soberania, que são considerados também como direitos fundamentais dos estados.

O magistério acima citado, do Professor Gonçalves Ferreira, denota a mudança, a quebra de paradigma havida no campo do Direito Internacional, que começa a tomar corpo a partir da Carta da ONU. Ao referir-se ao texto constitucional anterior, o Professor referese aos princípios que informam o conceito antes vigente, da coexistência pacífica, para transparecer que, no texto atual, já se nota a consagração da mudança de mentalidade, quando diz ver-se no texto de 1988 os princípios da cooperação e da soberania, em

\footnotetext{
${ }^{51}$ A definição de soberania, aqui, entendida na forma com que a exprime Walter Ceneviva (CENEVIVA, Walter. Direito constitucional brasileiro. São Paulo: Saraiva, 1989. p. 31): "Chama-se soberania o poder absoluto e originário de governo exercível, em nome do povo, pelo Estado, com independência, segundo suas próprias leis".

${ }^{52}$ MELLO, Celso D. de Albuquerque. op. cit., p. 31.
} 
convivência que, conforme se depreende do ensinamento de Celso D. de Albuquerque Mello, não é conflituosa, mas harmônica, uma vez que a soberania vem como forma de preservação da liberdade individual de cada Estado, e da democracia, enquanto a cooperação é princípio que informa a atuação dos Estados no campo internacional.

Insta, aqui, destacar nossa posição de filiação à teoria monista, fato bastante para justificar o desenvolvimento do ponto em exame, da necessidade de existência de sistema interno por meio do qual se verifique e chancele a harmonia entre os regramentos postos nos textos internacionais e as regras constitucionais de nosso Estado, cuidando ainda de estabelecer regras para a solução de conflito entre tais textos e a Constituição.

Reconhecemos que respeitável doutrina afirma termos no país um sistema de ordem dualista, dada a verificação prática de casos em que a postura brasileira no plano internacional não encontra eco no espaço interno. No entanto, entendemos que, em uma sociedade globalizada, em que as relações internacionais e internas se entrelaçam de forma clara, não restará espaço para o dualismo, em breve.

Luís Roberto Barroso ${ }^{53}$, ao abordar o tema dos tratados internacionais diante da Constituição, assim pondera e ensina:

O tema do conflito entre as normas internacionais e a ordem interna evoca duas grandes correntes doutrinárias que disputam o melhor equacionamento da questão: o dualismo, pregado no âmbito internacional por Triepel e Anzilotti e seguido no Brasil por Amílcar de Castro, e o monismo, concepção desenvolvida por Hans Kelsen e seguida no Brasil pela maior parte da doutrina, inclusive Valladão, Tenório, Celso D. de Albuquerque Mello e Marotta Rangel.

Para os dualistas, inexiste conflito possível entre a ordem internacional e a ordem interna simplesmente porque não há qualquer interseção entre ambas. São esferas distintas, que não se tocam. Assim, as normas de direito internacional disciplinam as relações entre Estados, e entre estes e os demais protagonistas da sociedade internacional. De sua parte, o direito interno rege as relações intraestatais, sem qualquer conexão com elementos externos. Nesta ordem de ideias, um ato internacional qualquer, como um tratado normativo, somente operará efeitos no âmbito interno de um Estado se uma lei vier incorporá-lo ao ordenamento jurídico positivo. Os autores se referem a esta lei como "ordem de execução".

O monismo jurídico afirma, com melhor razão, que o direito constitui uma unidade, um sistema, e que tanto o direito internacional quanto o direito interno integram esse sistema. Por assim ser, torna-se imperativa a existência de normas que coordenem esses dois domínios e que estabeleçam qual deles deve prevalecer em caso de conflito.

\footnotetext{
${ }^{53}$ BARROSO, Luís Roberto. Interpretação e aplicação da Constituição: fundamentos de uma dogmática constitucional transformada. 6. ed. São Paulo: Saraiva, 2004. p. 15-16.
} 
Nesse contexto é que se mostra absolutamente fundamental a regra da necessidade de internalização do instrumento de direito internacional, para que se sujeite o Estado a ele. Esse procedimento garante a verificação do atendimento aos conceitos da soberania e independência, significando a internalização do ato algo como que uma declaração de harmonia entre o ato internalizado e os princípios regentes da postura brasileira no âmbito das relações internacionais, e negando, por consequência, a existência de conflito entre Constituição Federal e texto internacional trazido à internalização.

Não é diferente em outras nações. Tratando especialmente da questão ambiental, Daniele Porena $^{54}$ demonstra, com autoridade, que a jurisprudência, na Itália, vem trazendo, nos últimos anos, a superação da visão dualista do direito, ali tradicional, para reconhecer a visão monista como mais adequada. Confira-se:

L'impressione è quella Che, per quanto concerne Le relazioni tra il nostro ordinamento e le fonti esterne, ci si trovi nel corso di uma nuova fase di transizione.

La tendenza giurisprudenziale Che emerge daí lavori della Corte (si pensi alle sentt. 406/2005 e n. 129/2006, con riferimento alle relazioni tra ordinamenti interno e comunitario, nonché le sentt. N. 378 e n. 379/2007 e, più di recente, la sent. N. 39/2008 com riferimento all'efficacia degli obblighi internazionali) sembrerebbe addirittura ispirata ad um parziale superamento della tradizionale impostazione dualista.

O fenômeno, na Itália, tem por origem principal a inserção daquele país na Comunidade Europeia e, mais genericamente, a globalização e a proliferação dos instrumentos internacionais multilaterais. Cada vez mais, esses instrumentos constituem fonte do direito interno, impondo a harmonização que a teoria monista vê como imprescindível. Daí o avanço de tal pensar na Itália, como em vários outros países.

Cabe aqui mesmo uma reflexão. Se, em tempos outros, até se poderia conceber, no plano das ideias, o entendimento da distinção e não interação entre o Direito Internacional e o Direito Interno, o atual estágio de desenvolvimento da sociedade, com a globalização da discussão e dos efeitos de várias das indagações jurídicas, jogou por terra qualquer justificativa que pudesse pretender sustentar a adoção da teoria dualista como melhor caminho. O desenvolvimento das relações humanas, e os efeitos destas, cuidaram de demonstrar o acerto dos que se filiaram à teoria monista, via única de harmonização entre a

\footnotetext{
${ }^{54}$ PORENA, Daniele. La protezione dell'ambiente tra Costituzione italiana e "Costituzione globale" Torino: G. Giappichelli, 2009. p. 33-35. (Collana di Studi di Diritto Pubblico).
} 
soberania e a cooperação internacional. ${ }^{55}$

Faz-se um parêntese, porquanto relevante: essa equalização entre o direito interno e o direito internacional, aliás, é degrau de um processo maior, de desestruturação do conceito de soberania territorial, e de avanço de uma nova ordem. Hans Kelsen, já em 1920, via esse caminho como inevitável:

Com a superação do dogma da soberania nos Estados singulares firmarse-á uma civitas maxima, um ordenamento de direito internacional, ou melhor, mundial, que será objetivo, independente de qualquer "reconhecimento" e superior aos Estados singulares. (tradução livre de Eros Grau, in O Direito e o futuro - o futuro do Direito, organizado por António José Avelãs Nunes e Jacinto Nelson de Miranda Coutinho, Almedina, 2008, páginas 595/596).

Essa sociedade supranacional, ditada pelo mercado e pela política, em planos que excedem o Estado singular, encontra sua soberania, nos dizeres de Eros Grau ${ }^{56}$, no plano da sociedade civil, dispensando-se assim, para o exercício dessa soberania, a mediação das instituições estatais.

No plano das relações entre Estados e o trato das questões de ordem ambiental, essa relativização da soberania como expressão do livre decidir de um determinado Estado, riscada pelos traços de seus limites territoriais, ganha especial relevância, dado que tal questão, a ambiental, desconhece fronteiras. Não por outra razão, já em 1988 o Conselho da Europa adotou, na carta da água, esse desacerto entre fronteiras políticas e alcance dos efeitos ambientais: A fronteira entre Estados separa os seus territórios de uma maneira efectiva e sensível, mas não corta a unidade física do terreno que divide. Nos dizeres de Michel Bachelet ${ }^{57}$, a única dimensão respeitável para o ambiente é o próprio planeta. Em consequência, por mais dignas de consideração que elas sejam, as fronteiras dos Estados não são linhas de separação dos elementos físicos constitutivos da natureza.

\footnotetext{
${ }^{55} \mathrm{O}$ desenvolvimento da nova ordem, a do Direito Internacional do Desenvolvimento, tem como um de seus fortes vetores, senão o principal, a adoção da Declaração Universal dos Direitos Humanos, de 1948, que estabelece o início de uma ordem de direitos, no campo internacional. Flavia Piovesan, ao tratar das alterações trazidas ao texto constitucional pela Emenda Constitucional 45, caracteriza com propriedade os direitos humanos, tanto no campo internacional, quanto no âmbito interno (PIOVESAN, Flávia. Federalização dos crimes contra os direitos humanos. Revista Brasileira de Ciências Criminais, São Paulo, ano 13 , v. 54 , p. 169-183, maio/jun. 2005).

${ }^{56}$ GRAU, Eros Roberto. In: NUNES, António José; COUTINHO, Jacinto Nelson de (Orgs.). $O$ direito e o futuro - o futuro do direito. Coimbra: Almedina, 2008. p. 595-596.

${ }^{57}$ BACHELET, Michel. A ingerência ecológica: direito ambiental em questão. Lisboa: Instituto Piaget, 1995. p. 257.
} 
Esse exercício da soberania pela sociedade civil se dá, no que tange às relações envolvendo o meio ambiente, pela imposição da postura de busca pela sustentabilidade. Conforme vimos acima, trazido o conceito de sustentabilidade, e absorvido este pela sociedade, deixou a lei de ser o parâmetro, para que, por impulso e exigência da sociedade, se inicie a busca por algo que excede a lei, que excede a ordem formal interna, para refletir um senso comum, de que o estado de sustentabilidade é o norte a ser perseguido. Entendemos se ver, aqui, o que previu Kelsen, e indicou Grau no texto transcrito.

Remi Aparecida de Araújo Soares ${ }^{58}$, citando Leonardo Boff, trata do tema, identificando o momento hoje vivido pela sociedade global, e o ideal ainda a perseguir:

Na segunda metade do século XX, surgiram o pensamento e a ação ecológica, substituindo a dominação do homem sobre a natureza, pela sua responsabilidade de um meio ambiente natural e cultural em perigo e empobrecido pelas intervenções econômicas em prol da modernização econômica, rumo a uma nova civilização.

Essa nova civilização não é apenas um sonho, ela está emergindo. A globalização ou mundialização faz com que as nações superem seus limites jurisdicionais, flexibilizando sua soberania, levando a humanidade a uma única sociedade mundial. A sociedade global ainda está na fase de globalização competitiva, oposta à globalização cooperativa, a qual almeja-se. Esta trata de uma mundialização estruturada sobre a ética, pelo senso de compaixão mundial, pela descoberta de direitos incondicionais, "direitos não dependentes do poder econômico e político dos povos ou do dinheiro de seu bolso, nem da cor de sua pele, nem da religião que professam. Estamos todos sob o mesmo arco-íris da solidariedade, do respeito e valorização das diferenças e movidos pela amorização que nos faz a todos irmãos e irmãs".

Fecha-se o parêntese. Voltando ao tema da cooperação internacional, vem bem a propósito o comentário de Celso Ribeiro Bastos e Ives Gandra Martins ${ }^{59}$, que, ao cuidar do propósito da realização do princípio da cooperação internacional, explanam que este se materializa por meio de duas vias, a bilateral e a multilateral (comprovação prática, pois, de que o direito internacional e o interno interagem e convivem em um só plano). No que toca à via multilateral, assim se manifestam os autores:

Na segunda, abre-se o leque a múltiplos interessados, dando lugar, assim, ao surgimento de organizações de cunho mundial ou então regional. Não

\footnotetext{
${ }^{58}$ SOARES, Remi Aparecida de Araújo. Proteção ambiental e desenvolvimento econômico: conciliação. Curitiba: Juruá, 2004. p. 166-167.

${ }^{59}$ BASTOS, Celso Ribeiro; GANDRA MARTINS, Ives. Comentários à Constituição do Brasil. São Paulo: Saraiva, 1988. v. 1, p. 460.
} 
é difícil prever-se que essas organizações deverão ter um papel cada vez mais importante, uma vez que as fronteiras do Estado estão como que a explodir diante da magnitude dos problemas.

Já em 1988 os autores citados afirmavam a importância do dispositivo constitucional da cooperação internacional, dado o fenômeno segundo o qual se assume a sensibilidade da natureza transfronteiriça, sem limites geográficos, de muitas das indagações e questões afetas ao ser humano. A inserção do dispositivo, portanto, para além de legitimar condutas como a vinculação do Estado brasileiro a instrumentos internacionais como os aqui em exame, representa o reconhecimento de uma nova realidade, que é a da globalização das questões que afetam o ser humano.

Resta claro portanto que, no que toca à questão formal da participação brasileira na formulação e desenvolvimento dos regramentos internacionais que estabelecem metas comuns, de cooperação internacional, para a busca de um resultado igualmente comum, nada em nosso sistema veda, afasta ou ainda recomenda não se ter a postura adotada pelo Brasil, de adesão e participação em tal cenário. Essa participação materializa a aplicação do princípio constitucional da cooperação internacional.

Daí porque deu-se, em nosso sistema, a internalização do texto da ConvençãoQuadro sobre Mudança do Clima, por meio do Decreto ${ }^{\circ}$. 1, de 3.2.1994, que Aprova o texto da Convenção-Quadro das Nações Unidas sobre Mudança do Clima, adotada em Nova Iorque, em 9 de maio de 1992 (posteriormente, em 1.1.1998 deu-se a promulgação da Convenção-Quadro sobre Mudança do Clima, por meio do Decreto n ${ }^{\circ}$. 2.652, de 1.7.1998, com a determinação de seu cumprimento).

A forma de realização desse mister, recentemente estabelecida, mas ainda carente de regulamentação em nossos sistema, é que orienta as propostas que se formularão neste trabalho. Nos próximos capítulos será detalhada a questão do trato jurídico da mudança do clima, nos planos internacional e interno, os princípios envolvidos, e as medidas para a implementação de seus objetivos.

A implementação da defesa e preservação do meio ambiente, nesse contexto, ganha duas novas variáveis fundamentais: busca da sustentabilidade como norte, e controle das emissões de GEE como condição a esse norte. 


\section{(3) conclusão final do ponto - o ambiente para inovações e os fundamentos gerais da proposta}

Do momento em que, pela publicação da Lei $n^{\circ}$. 6.938/81, instituiu-se em nosso sistema a Política Nacional do Meio Ambiente, até os dias atuais, trinta anos após, em que novos princípios, desafios e paradigmas se apresentam, verificou-se que o sistema eleito em 1981, de comando e controle, materializado pelo licenciamento ambiental, e complementado pela imputação de responsabilidade nas três esferas, administrativa, criminal e civil, operando-se esta pela modalidade objetiva, revelou-se parcialmente eficaz, trazendo avanços mas não alcançando o resultado ideal, de absoluto controle e submissão das atividades de risco ambiental, e do risco ambiental propriamente dito, pelo sistema voltado à referida defesa e preservação ambiental.

O grande desafio que se apresenta, diante dessa situação, é o da busca de mecanismos novos, adicionais e complementares ao sistema de comando e controle, por meio dos quais se possa otimizar a harmonização entre produção econômica e crescimento social com a preservação do meio ambiente. Tudo como forma de alcançar e efetivar, através da defesa e preservação do meio ambiente, o direito a tê-lo "ecologicamente equilibrado". Ou, em outras palavras, tudo como forma de se alcançar um estado de sustentabilidade nas relações entre economia - sociedade - meio ambiente.

A teoria econômica já aceita o fato de que o meio ambiente, pela escassez de recursos naturais, é que impõe limite à produção, e não o oposto. Essa a manifestação de Geraldo Mario Rohde ${ }^{60}$, em sua Tese de Doutorado, submetida ao Instituto de Biociências da Universidade Federal do Rio Grande do Sul:

A Economia Ecológica (Costanza (Ed.), 1991; Odum, 1996; Merico,
1996; Costanza et al., 1997; Faber; Manstetten; Proops, 1998) é baseada
nos conceitos e definições da Economia Energética (Odum, 1980; Odum
\& Odum, 1981; Odum, 1988; Wackernagel \& Rees, 1995 e Odum, 1996),
tais como os diagramas de sistemas energéticos (baseados, por sua vez,
nas leis da energia), hierarquias energéticas e as transformidades, tendo
surgido nos Estados Unidos, na Costa Leste (UMD Marítima, NYU/New
School, Boston, IBRD), no final da década de 1980:

"A economia ecológica reconhece, antes de mais, empiricamente que os atos econômicos, para além do comportamento do homo oeconomicus e das relações sociais do mercado, correspondem a uma utilização material,

\footnotetext{
${ }^{60}$ ROHDE, Geraldo Mario. Economia ecológica da emissão antropogênica do CO2: uma abordagem filosófico-científica sobre a efetuação humana alopoiética da terra em escala planetária. Porto Alegre: Instituto de Biociências da Universidade Federal do Rio Grande do Sul, 2003. p. 108.
} 
energética e viva do ambiente e que esta utilização é, fundamentalmente, uma destruição criadora. Reconhece, em seguida, racionalmente que o mercado não decide a escala à qual utiliza o ambiente e que desta relação resultam restrições globais". (Pillet, 1997, p. 201).

O que se vê, portanto, é que, no campo das ciências econômicas, já se tem estruturado o entendimento segundo o qual a criação econômica necessariamente passa e traz como resultado a intervenção destrutiva sobre o meio ambiente, cabendo ao Homem a busca do equilíbrio nessa relação. Esse equilíbrio, fundado no uso e apropriação racional dos recursos naturais, de forma que se os defenda e preserve para as presentes e futuras gerações, é que se denomina de sustentabilidade.

Os mecanismos a serem introduzidos como complemento ao sistema de comando e controle, portanto, devem tocar a essa relação, entre a produção econômica e a finitude dos recursos naturais apropriados e afetados, de maneira a que o equilíbrio seja obtido pelo estímulo às atividades positivas nessa relação, e pelo desestímulo às atividades negativas quanto a tal aspecto. O papel de transformação e modificação do Estado sobre as relações econômicas e sociais deve manifestar-se aí, de forma clara, e por regras bem definidas.

Vale aqui como norte a lição de Canotilho ${ }^{61}$, quanto às três ordens de funções do Estado: a uma, a manutenção de uma ordem-quadro para o exercício da liberdade política e económica; a duas, a função de segunda ordem, por meio de uma política de 'intervenção' e 'estímulo' com o fim de criar instrumentos de 'integração' necessários à organização capitalista da economia; e, como funções de terceira ordem, intervenções qualitativas na ordem económica existente.

No contexto da segunda e principalmente da terceira ordem de função do Estado é que se deve focar a definição dos instrumentos viabilizadores da busca por um sistema que conduza à sustentabilidade, dada a verificada ineficiência e incompletude do sistema vigente, que representa a materialização da primeira, especialmente, mas também da segunda ordem de função do Estado.

Sob esse pensamento condutor é que trataremos das propostas para implementação dos objetivos da Política Nacional de Mudança do Clima, no que toca à energia e às florestas.

\footnotetext{
${ }^{61}$ CANOTILHO, J. J. Gomes. Direito constitucional e teoria da Constituição. Coimbra: Coimbra Ed., 1997. p. 326-327.
} 


\section{A POSTURA BRASILEIRA NO ÂMBITO DA CONVENÇÃO- QUADRO SOBRE A MUDANÇA DO CLIMA E A QUESTÃO NO PLANO INTERNO}

Conforme se viu até aqui, hoje a variável climática insere-se no trato da questão ambiental de forma indissociável, e a busca da defesa e preservação do meio ambiente, visando a alcançar uma condição de sustentabilidade, deve ter em conta essa variável.

Consequentemente, a proposta que se pretende apresentar, para a implementação da intervenção qualitativa do Estado na questão ambiental sob a perspectiva da variável climática, somente poderá ser adequada desde que considere a postura brasileira nas relações internacionais e as políticas públicas e mecanismos internos que tocam ao ponto.

Daí porque, neste tópico, cuidar-se-á de verificar a postura brasileira nos debates acerca da questão climática, assim como examinar-se-á as ferramentas de âmbito interno, já aprovadas ou em tramitação, voltadas à questão.

(1) a Convenção-Quadro, o Protocolo de Quioto, a postura brasileira nas negociações e a peculiar condição nacional diante das emissões de GEE

Já se destacou, neste trabalho, que a Convenção-Quadro sobre Mudança do Clima constitui instrumento cujo objetivo central é o de conduzir os Estados-Parte à adoção de medidas, individuais ou conjuntas, que tenham como resultado a redução das emissões de GEE, assim como a mitigação de seus efeitos e a adaptação às transformações causadas pela mudança do clima.

Destacou-se a atuação brasileira na negociação do que viria constituir a ConvençãoQuadro. Desde a Assembleia de Estocolmo, em 1972, passou a nossa representação diplomática a defender, de maneira consistente e coerente, que o trato da questão ambiental somente seria eficaz se vinculada à viabilização do crescimento dos países em desenvolvimento. A pobreza é o maior inimigo do meio ambiente, essa a mensagem transmitida pela diplomacia brasileira (ou, conforme o saudoso Professor Guido Soares dizia aos seus alunos, a postura brasileira, nas negociações internacionais voltadas à 
questão ambiental, sempre foi a de que "não se respeita o verde onde se está no vermelho").

Nesse contexto é que, quando do início das discussões visando ao estabelecimento da Convenção-Quadro sobre Mudança do Clima, defendemos duas premissas à negociação: a primeira delas, levada à mesa não apenas, mas também pelo Brasil, e aceita indistintamente pela grande maioria dos Estados envolvidos, até porque irrefutável, é a de que a responsabilidade pelo combate às emissões de GEE e de seus efeitos não deveria ser distribuída de forma igualitária ou solidária entre os Estados-parte que firmariam a Convenção-Quadro, uma vez que, dada a cumulatividade das emissões de GEE, a contribuição histórica dos Estados-parte desenvolvidos revela-se desproporcional às emissões causadas pelos Estados-parte em desenvolvimento. Dessa forma, seria razoável e a proposta teve aceitação e formalização - estabelecer uma estrutura pela qual se adotasse o conceito da responsabilidade comum mas diferenciada. Significa tal conceito que todos são responsáveis pelo combate às emissões de GEE e implementação de medidas voltadas ao combate e mitigação de seus efeitos, cabendo no entanto a alguns responsabilidade em maior escala pela adoção das medidas voltadas e esse propósito.

A segunda proposta levada pelo Brasil à mesa de negociação diz respeito à forma de equalização das condições entre as partes. Partindo do pressuposto de que os Estados-parte em desenvolvimento devem ter o direito a desenvolver-se, de forma a equalizar suas condições econômicas e sociais às dos Estados-parte desenvolvidos, propôs nossa representação nas tratativas da Convenção-Quadro que, para se alcançar tal patamar, sem se elevar as emissões de GEE por parte dos Estados-parte em desenvolvimento, coubesse aos Estados-parte desenvolvidos lastrear um fundo dedicado ao financiamento de tecnologias orientadas a garantir esse desenvolvimento dos Estados-parte em desenvolvimento, sem o incremento de suas emissões de GEE.

A proposta brasileira encontrou resistência por parte dos Estados-parte desenvolvidos, que se opuseram a financiar a otimização das condições de competição da indústria nos Estados-parte em desenvolvimento, dado verem aí um investimento que, alcançado seu objetivo, deprimiria a competitividade desses Estados-parte desenvolvidos.

Da discussão quanto às formas de financiamento da adoção das tecnologias necessárias ao crescimento dito "limpo" (sem o incremento - e, se possível, até mesmo com a redução - das emissões de GEE) dos Estados-parte em desenvolvimento, surgiu, 
como forma alternativa de alcance a esse objetivo, o Mecanismo de Desenvolvimento Limpo - MDL, inserto no artigo 12 do Protocolo de Quioto.

Não cabe aqui descer a detalhes estruturais acerca do MDL, interessando apenas destacar que tal instrumento viabilizou-se a partir da proposta defendida pelo Brasil, de criação de mecanismos de financiamento do desenvolvimento limpo dos Estados-parte em desenvolvimento, com o acréscimo da contrapartida aos financiadores dos projetos de tal ferramenta, constituindo-se esta no Certificado de Emissões Reduzidas - CER, ou crédito de carbono, conforme denominação dada pelo mercado.

O MDL, com essa sua estrutura, de financiamento ou transferência de tecnologia a um projeto, para dele se obter a redução das emissões de GEE, e com a geração, em contrapartida, de um crédito, o CER (confira-se o diagrama a seguir), é a base adotada para a negociação, no âmbito da Conferência das Partes da Convenção-Quadro sobre Mudança do Clima, para o estabelecimento do instrumento viabilizador dos projetos do que se convencionou denominar de REDD+ (essa sigla significa que o instrumento prestar-se-á ao financiamento da redução das emissões de GEE decorrentes do desmatamento e degradação das florestas, com manejo sustentável destas admitido).

Nesse contexto, pois, é que se posiciona o Brasil no âmbito da cooperação internacional para combate às emissões de GEE e o trato de seus efeitos. Da proposta inicial, de financiamento do crescimento limpo pelos Estados-parte em desenvolvimento, adaptou-se nossa postura e, agora, aceitamos que essa via de financiamento do desenvolvimento limpo (ou, no caso das REDD+, de financiamento da redução das emissões decorrentes do desmatamento e da degradação das florestas) tenha uma contrapartida, referida pelos "créditos" correspondentes à tonelagem de carbono que, em decorrência mesmo do projeto aplicado, se deixou de emitir para a atmosfera.

Tal postura, aliada à defesa cega e intransigente da manutenção de nossa soberania sobre o território nacional, revela-se em outra frente de discussão atinente à questão climática, que à nossa condição diante da mudança do clima toca de forma direta. Trata-se da questão das florestas diante do tema da mudança do clima, tema que emergiu nas discussões no âmbito da Convenção-Quadro sobre Mudança do Clima em 
2005, na Conferência das Partes - COP de Montreal ${ }^{62}$.

Essas discussões, de busca de um instrumento econômico que viabilize a preservação das florestas remanescentes no mundo, considerado o carbono absorvido e fixado por essas florestas durante sua formação, desenvolvimento e consolidação, é de especial interesse e importância para o Brasil. Isto porque somos a única nação no mundo cujas emissões de GEE não têm como fonte primordial a queima de combustíveis fósseis, mas sim e antes as queimadas e o desmatamento.

Nesse cenário, o estabelecimento de um instrumento internacional que permita financiar a preservação de nossas florestas, respeitada nossa soberania sobre o território brasileiro e os bens que o compõem, aí incluídas as florestas, seria um instrumento viabilizador da redução de nossa principal fonte de emissão de GEE.

Vale destacar aqui que a implementação de um instrumento com tal perfil, que tenha como resultado da alocação de recursos a preservação de nossas florestas, terá não apenas o condão de reduzir nossas emissões de GEE decorrentes do desmatamento e das queimadas, mas também terá, como resultado, a preservação de nosso patrimônio biodiverso, atendendo assim, pelo mesmo ato, aos objetivos da Convenção sobre a Diversidade Biológica, da qual é o Brasil igualmente signatário ${ }^{63}$.

Ocorre, no entanto, que as tratativas para a implementação desse mecanismo internacional, voltado à definição de meios para o financiamento da preservação de florestas, o REDD+, vêm encontrando óbices técnicos e negociais/políticos, razão pela qual, desde o início dos debates, em 2005, em Montreal, até a COP de Durban, realizada em dezembro de 2011, não se logrou definir o texto de tal mecanismo, ficando as iniciativas e projetos de REDD+ relegados ao dito mercado voluntário, em que se aplica os projetos de forma voluntária, e se negocia os "créditos" resultantes (para cada tonelada de carbono medida e fixada pela floresta preservada, que sem o projeto estaria sob risco claro de desmatamento e/ou degradação, com a liberação desse carbono para a atmosfera,

\footnotetext{
${ }^{62}$ Para referência acerca do contexto de formulação da Convenção-Quadro sobre Mudança do Clima, o Protocolo de Quioto e o Mecanismo de Desenvolvimento Limpo, assim como as discussões acerca do tema das florestas e a mudança do clima, iniciadas em 2005, vide meu O Protocolo de Quioto e o Mecanismo de Desenvolvimento Limpo - MDL: uma análise crítica do instituto, cit.

${ }^{63}$ Interessante, neste passo, destacar que a questão da integração entre a Convenção-Quadro Sobre Mudança do Clima e a Convenção sobre a Diversidade Biológica foi já objeto de estudo por Farhana Yamin e Joanna Depledge, na obra The international climate change regime: a guide to rules, institutions and procedures. Cambridge University Press, 2004, conforme comentei em meu já citado O Protocolo de Quioto e o Mecanismo de Desenvolvimento Limpo - MDL: uma análise crítica do instituto, cit.
} 
corresponde um “crédito de REDD+), em regra, de forma bilateral, sem reconhecimento de sua validade pelos órgãos da Convenção-Quadro sobre Mudança do Clima.

\section{(2) a legislação interna e propostas em trâmite}

Esse estado das negociações, de indefinição acerca do instrumento de institucionalização do REDD+, naturalmente em nada agrada aos Estados-parte detentores de florestas preservadas.

Mas a nenhum outro Estado-parte da Convenção-Quadro sobre Mudança do Clima o tema é tão caro quanto ao Brasil, seja em razão da dimensão de nossas florestas (pode-se dizer ser o Brasil o "G1 das florestas"), e o risco a que estão submetidas, seja em razão de termos em nosso rol de fontes de emissão de GEE o desmatamento e as queimadas como item primeiro; seja, ainda, em razão de nossa natural preocupação em garantir que, do estabelecimento do instrumento voltado ao financiamento e viabilização dos projetos de REDD+, não decorram regras que, porque potencialmente ofensivas à soberania brasileira sobre nossas florestas, ou sobre as nossas políticas públicas para o trato de sua preservação e exploração racional, nos impeçam de aderir a tal instrumento.

Nesse cenário é que, em 2009, diante da realização da COP de Copenhagen, adotamos postura mais incisiva e mais de liderança ainda do que vínhamos até então adotando, desde 2005, em Montreal, quando tiveram início as discussões para o instrumento viabilizador do financiamento de projetos de REDD+. Isso porque, em Copenhagen, dois fenômenos encadeados se verificaram: a uma, alimentava-se na sociedade civil - em nossa opinião em razão de desvio no exame do estado das tratativas para institucionalização do instrumento e dos obstáculos ainda a ser vencidos - uma enorme expectativa de que em Copenhagen seria atingido o consenso para a formalização de tal instrumento (o viabilizador do financiamento dos projetos de REDD+).

A duas, muito em razão da pressão da sociedade civil, e da dimensão política que passou a permear as discussões da questão do clima (sempre esteve tal variável presente; no entanto, em Copenhagen, pela primeira vez observou-se tal fenômeno superar as vertentes científicas, de mercado e idealistas, no cenário das discussões da COP), pela primeira vez viu-se, em uma COP da Convenção-Quadro sobre Mudança do Clima, a presença de Chefes de Governo e de Estado em massa (até então, apenas em uma COP, em 
Bali, 2007, se tinha anotado a presença de um Chefe de Governo ou Estado; no caso, o Presidente local), transportando o peso maior das negociações, como consequência, para a vertente política do processo de formação decisória da assembleia dos Estados-parte da Convenção-Quadro sobre Mudança do Clima.

O cenário, portanto, era muito propício a "pirotecnias" políticas, a atos de chamamento de atenção e responsabilidade para seu emissor. Hábil como poucos líderes em fazer dessas situações palco para dar destaque aos feitos de nosso país, nosso então mandatário declarou, a plenos pulmões, que as intrincadas relações negociais, no âmbito das quais, em algumas situações, a assunção de metas efetivas de redução de emissões de GEE, por alguns Estados-parte, dentre estes o Brasil, eram cobradas como requisitos a contrapartidas por aqueles a quem cobrávamos igualmente medidas (Estados Unidos da América, China e Austrália, por exemplo), não constituiriam óbice a que, unilateralmente, assumíssemos ali, como exemplo a ser seguido pelos demais, metas voluntárias de redução de nossas emissões de GEE. Ipsis literis, assim declarou nosso Presidente:

Daí o nosso compromisso de reduzir seu desmatamento em $80 \%$ até 2020. O Congresso brasileiro aprovou Projeto de Lei de iniciativa do Executivo, que contém um conjunto de ações envolvendo combate ao desmatamento, agricultura, energia e siderurgia. Essas medidas deverão reduzir o crescimento das emissões brasileiras de GEE entre 36,1 e 38,9 até 2020. Esse esforço nos custará 160 bilhões de dólares, ou seja, 16 bilhões de dólares por ano até 2020. Mas esta não é uma proposta para barganhar. É um compromisso que assumimos com a nação brasileira e com o mundo.

(...)

É inaceitável que os países menos responsáveis pela mudança do clima sejam suas primeiras e principais vítimas.

Nosso então Presidente da República, Luís Inácio Lula da Silva, causou furor ao declarar que ali, naquele ato, assumíamos a meta voluntária de redução de nossas emissões de GEE em 36,1\% a 39,8\%, tomado como base o volume de emissões inventariadas para 1990.

A declaração teve efeitos imediatos. Porque formulada pelo representante maior de nossa Nação, no âmbito de ambiente oficial para o tema a que se referiu, o que a tornou vinculante, em relação a seu conteúdo imediato, para o Brasil. Ou seja, a partir daquele momento, posta a declaração, já não poderíamos voltar atrás, sob qualquer argumento, sob pena de perda de nossa credibilidade e posição de liderança nas negociações acerca da 
questão do clima no cenário da Convenção-Quadro, já que caracterizar-se-ia irresponsável e impensada bravata.

Tal conteúdo imediato forma-se pela conjugação dos seguintes elementos:

(i) voluntariedade da assunção de metas, no plano internacional, pelo Brasil, significando que nossa decisão de assumir metas de redução de emissões de GEE não se vincula a qualquer condição;

(ii) submissão aos efeitos aplicáveis ao não cumprimento dessas metas, nas mesmas condições aplicáveis a Estados-parte vinculados a metas por força não de declaração voluntária, mas de processo de negociação incluindo contrapartidas;

(iii) impossibilidade de acesso, em tese, aos benefícios concedidos àqueles que se vinculam a metas, pelo processo negocial, mediante a condição de acesso a tais benefícios (na prática, essa restrição não se aplica); e

(iv) assunção da obrigação de estabelecimento, no plano interno, das normas necessárias à garantia do cumprimento às metas declaradas (a Lei 12.187/2009 já havia sido então aprovada, conforme mencionou o Presidente em seu discurso).

Os itens ii e iii acima não ganham relevância para o debate que aqui se propõe, porque não aplicáveis ao contexto prático atual (como ainda não se tem o sistema institucional disciplinando a obrigatória redução de emissões de GEE por Estados-parte em desenvolvimento, como o Brasil, não se tem, nesse ambiente, o institucional, benefícios e penalidades disponíveis para a instrumentalização de medidas voltadas ao cumprimento de metas, ou ao seu não cumprimento).

Já no que toca aos itens i e iv, trata-se de consequências, derivadas da declaração feita por nosso Presidente da República, que impõem duas ordens de conduta: no plano internacional, a responsabilidade por materializar o exemplo dado em Copenhagen, sob pena da já indicada perda de credibilidade e posição de liderança, e, no plano interno, a adoção das ferramentas legais necessárias à implementação das metas assumidas, aqui já não se dando o processo de forma voluntária, mas sim em caráter mandatório. 
Isso porque a declaração realizada, se voluntária em seu conceito e conteúdo, no plano das relações internacionais, caracteriza fonte do direito em nosso ordenamento, devendo ser internalizada, para que passe a integrar nosso ordenamento, atendendo a todas as regras estruturais de validade para que ali se insira de forma válida e eficaz.

Já se viu, neste trabalho, que a internalização da Convenção-Quadro sobre Mudança do Clima era de rigor, dados os princípios constitucionais da cooperação internacional e da busca pelo meio ambiente ecologicamente equilibrado, em caráter intergeracional.

Os mesmos argumentos aplicam-se à internalização da obrigação voluntária assumida espontaneamente pelo Brasil. Ainda que em forma não escrita, e sem observância de regras formais e salvaguardas de adesão e aplicabilidade, o fato é que, pelas razões já indicadas, de forma unilateral vinculamo-nos a uma obrigação que, não obstante posta no plano das relações internacionais, tem efeitos internos imediatos, já que o alcance do objetivo (meta) anunciado somente se poderá materializar pela efetiva redução, em sede interna, de nossas emissões de GEE.

Daí a necessidade de internalização, não de um instrumento jurídico internacional (Convenção, Tratado, Protocolo ou Declaração bilateral ou multilateral, em atendimento às regras estabelecidas na forma da Convenção de Viena sobre o Direito dos Tratados), mas do conteúdo posto em declaração unilateral que, como já dito, nos vincula a esse conteúdo.

A "internalização", ou materialização desse conteúdo, da meta assumida, e a determinação, no plano interno, da forma de sua implementação, reclama o estabelecimento de lei em sentido estrito, já que, em nosso ordenamento, até então, não constava qualquer obrigação de redução de nossas emissões de GEE. O fato de a inserção do conteúdo da declaração em questão implicar a obrigação, oponível ao próprio Estado e aos administrados, de redução de nossas emissões de GEE, é que a vincula, no que toca à forma, à lei em sentido estrito, não servindo a tanto decreto de qualquer natureza, para que não se ofenda ao princípio estatuído no artigo $5^{\circ}$, II, da Constituição Federal (ninguém será obrigado a fazer ou deixar de fazer alguma coisa senão em virtude de lei). 


\section{(i) a Lei no. 12.187/2009 - A Política Nacional sobre Mudança do Clima}

Andou bem nosso legislador, no que toca ao atendimento do ponto. Com efeito, logo após a declaração de submissão a metas, realizada em Copenhagen, foi publicada a Lei $n^{\circ}$. 12.187, de 29.12.2009, por meio da qual se instituiu a Política Nacional sobre Mudança do Clima, efetivando-se, no plano interno, a estrutura estatal e os princípios e diretrizes a serem observados, em sede de regulamentação, para a implementação dos instrumentos dedicados à concretização dos objetivos de tal política nacional.

\section{- os princípios postos na lei}

Interessante destacar que, na forma do artigo $3^{\circ}$ da referida lei, os princípios a informadores da Política Nacional sobre Mudança do Clima e das ações dela decorrentes abrangem desde o princípio que orienta e justificou a adoção do sistema do licenciamento ambiental (prevenção), passando por princípios outros trazidos pela Declaração do Rio de Janeiro sobre Meio Ambiente e Desenvolvimento (precaução, participação, desenvolvimento sustentável), para adotar, ao final, o princípio prestigiado pela Convenção-Quadro sobre Mudança do Clima (responsabilidades comuns mas diferenciadas).

Quer-nos parecer que o intento do legislador foi o de conferir à Política Nacional sobre Mudança do Clima, e a suas ferramentas, a maior abrangência possível, de forma a se poder, na implementação das ações voltadas à sua efetivação, lançar mão de ferramentas como o licenciamento ambiental vinculado à variável climática (esta como elemento de formação decisória daquele), sob o signo da precaução, e não apenas a prevenção; ou ainda de ferramentas como o licenciamento ambiental vinculado a critérios de sustentabilidade do negócio pretendido; e, finalmente, com a observância, sempre, do princípio que, em âmbito das relações internacionais, orienta os diferentes graus de responsabilidade entre aqueles

que mais e menos contribuíram, no acumulado histórico, para as emissões de GEE e ocorrência de seus efeitos.

Não obstante o zelo do legislador, parece-nos ter ocorrido omissão, na definição dos princípios norteadores da Política Nacional sobre Mudança do Clima, quanto à inclusão do princípio do protetor-recebedor. Tal princípio, a nosso ver, não poderia ser deixado de lado, quando se pensa em uma política nacional para trato da questão da mudança do clima, em nosso país. 
Conforme já posto neste trabalho, temos a condição sui generis de vermos o grosso de nossas emissões de GEE decorrerem das queimadas e desmatamento. Ora, considerando a questão das florestas, e a consideração -imprescindível - da variável atinente aos que nela habitam - povos tradicionais, povos indígenas, ribeirinhos, etc. - e dela vivem, não se pode abrir mão, como ferramenta de implementação de uma política atinente a tais florestas, do uso dos princípios do usuário-pagador e, principalmente, do protetorrecebedor. Isto porque, observados os princípios atinentes ao direito ambiental, e as relações entre florestas e esses agentes, fica evidente o fato de que, para a harmonização dessas relações, com a superação do paradigma da conduta predatória como resposta à pobreza (levando ao "onde se está no vermelho não se respeita o verde", do Professor Guido Soares), não se poderá prescindir dessa ferramenta, do prestígio àquele que protege e preserva a floresta, em troca de remuneração fundada no interesse nacional em ter o ativo representado pela floresta preservado.

O ponto será visitado novamente, em mais detalhes, ao tratarmos, mais além, dos mecanismos propostos para a questão das florestas, no âmbito da Política Nacional sobre Mudança do Clima, observado o papel de intervenção qualitativa do Estado. Mas cumpre fazer, desde já, essa ressalva à completude da Política Nacional sobre Mudança do Clima, trazida pela Lei $\mathrm{n}^{\mathrm{o}}$. 12.187/2009.

\section{- as ações para implementação da Política Nacional sobre Mudança do Clima}

Voltando à lei, o mesmo artigo $3^{\circ}$, ao tratar das ações de implementação da Política Nacional sobre Mudança do Clima declara (inciso IV) que o desenvolvimento sustentável é a condição para enfrentar as alterações climáticas e conciliar o atendimento às necessidades comuns e particulares das populações e comunidades que vivem no território nacional, ao mesmo tempo em que vincula tais ações (inciso III) aos contextos socioeconômicos sobre os quais se assentarão, determinando a distribuição dos ônus e encargos decorrentes entre os setores econômicos e as populações e comunidades interessadas de modo equitativo e equilibrado, sopesando-se as responsabilidades individuais quanto à origem das fontes emissoras e dos efeitos ocasionados sobre o clima.

A inserção da variável socioeconômica no contexto das ações de implementação da Política Nacional sobre Mudança do Clima é elemento de fundamental importância à efetividade dessas ações, e guarda coerência com a postura brasileira diante da interação 
entre as questões ambiental e econômica. Defendida desde sempre pela nossa diplomacia a manutenção e respeito à nossa soberania, e defendido o entendimento, nos debates acerca das relações entre o Homem e o meio ambiente, desde 1972, de que não se pode, no afã de alcançar a preservação ambiental, comprometer a capacidade dos países menos desenvolvidos de alcançar a condição de desenvolvimento econômico e social já vivida pelos mais desenvolvidos.

A vinculação das ações de implementação da Política Nacional sobre Mudança do Clima à variável socioeconômica, com a distribuição equitativa de ônus e encargos, portanto, revela o firme propósito de, na materialização interna do quanto declarado e assumido como meta, no plano internacional, ver-se preservadas nossa soberania, e a viabilidade do alcance do crescimento econômico e social ainda em andamento no Brasil. Não por outra razão, declara-se no artigo $4^{\circ}$ que a Política Nacional sobre Mudança do Clima visará à compatibilização do desenvolvimento econômico-social com a proteção do sistema climático, tomando-se em conta como uma de suas diretrizes (definidas pelo artigo $5^{\circ}$ ), na aplicação das ações voltadas à sua implementação, notadamente aquelas ditas de adaptação (que buscam adaptar o meio afetado pela mudança do clima aos seus efeitos), a vulnerabilidade dos sistemas ambiental, social e econômico (artigo $5^{\circ}$, II);

\section{- as diretrizes para a implementação da Política Nacional sobre Mudança do Clima}

Diretriz fundamental, e central para este trabalho, é a posta no inciso XIII, alíneas "a" e "b" do artigo 50, que elegem o estímulo e apoio à manutenção e promoção (a) de práticas, atividades e tecnologias de baixas emissões de gases de efeito estufa; e (b) de padrões sustentáveis de produção e consumo. Ver-se-á mais adiante que o fundamento constitucional à viabilização de tais medidas (e a outras, voltadas à consecução do objetivo maior de redução de emissões nacionais de GEE) encontra-se na redação atual do inciso VI do Parágrafo Único do artigo 170 da CF, conforme redação dada pela Emenda Constitucional 42/2003, posto que práticas, atividades e tecnologias de baixas emissões de gases de efeito estufa devem ser havidas como constituintes do que ali, no fundamento constitucional, define-se como produtos e serviços, e seus processos de elaboração e prestação, que, dado seu impacto ambiental, fazem jus a tratamento diferenciado (tratamento diferenciado que se materializa pelo tratamento 
diferenciado no que toca ao tratamento tributário, conforme defenderemos, tomada a função de intervenção qualitativa do Estado na ordem econômica).

\section{- os instrumentos da Política Nacional sobre Mudança do Clima}

Dentre os instrumentos da Política Nacional sobre Mudança do Clima, definidos no artigo $6^{\circ}$ da lei, são de especial interesse para o objeto deste trabalho os incisos VI, VII, IX, X, XI, XII, XVI e XVII, reproduzidos abaixo, e que tratam dos mecanismos de financiamento e estímulo à consecução dos objetivos da lei (incisos VI, VII e IX a XII), assim como dos referenciais a serem considerados para este mister (incisos XVI e XVII):

VI - as medidas fiscais e tributárias destinadas a estimular a redução das emissões e remoção de gases de efeito estufa, incluindo alíquotas diferenciadas, isenções, compensações e incentivos, a serem estabelecidos em lei específica;

VII - as linhas de crédito e financiamento específicas de agentes financeiros públicos e privados;

(..)

IX - as dotações específicas para ações em mudança do clima no orçamento da União;

$\mathrm{X}$ - os mecanismos financeiros e econômicos referentes à mitigação da mudança do clima e à adaptação aos efeitos da mudança do clima que existam no âmbito da Convenção-Quadro das Nações Unidas sobre Mudança do Clima e do Protocolo de Quioto;

XI - os mecanismos financeiros e econômicos, no âmbito nacional, referentes à mitigação e à adaptação à mudança do clima;

XII - as medidas existentes, ou a serem criadas, que estimulem o desenvolvimento de processos e tecnologias, que contribuam para a redução de emissões e remoções de gases de efeito estufa, bem como para a adaptação, dentre as quais o estabelecimento de critérios de preferência nas licitações e concorrências públicas, compreendidas aí as parcerias público-privadas e a autorização, permissão, outorga e concessão para exploração de serviços públicos e recursos naturais, para as propostas que propiciem maior economia de energia, água e outros recursos naturais e redução da emissão de gases de efeito estufa e de resíduos;

XVI - os indicadores de sustentabilidade;

XVII - o estabelecimento de padrões ambientais e de metas, quantificáveis e verificáveis, para a redução de emissões antrópicas por fontes e para as remoções antrópicas por sumidouros de gases de efeito estufa; 
Desses instrumentos, para os fins deste trabalho, sobressai o inciso VI, cuja importância reside em trazer a complementação ao princípio posto no texto constitucional: o tratamento diferenciado a que se reporta o inciso VI do p.ú. do artigo 170 da CF seria materializado, entre outras formas, pela adoção das medidas fiscais e tributárias referidas pelo inciso VI do artigo $6^{\circ}$ da Lei $n^{\circ}$. 12.187 , destinadas a estimular a redução das emissões e remoção de GEE, incluindo alíquotas diferenciadas, isenções, compensações e incentivos, a serem estabelecidos em lei específica, permitindo assim que se realize a intervenção qualitativa do Estado sobre a ordem econômica, estimulando-se e privilegiando-se condutas que tendem à direção da sustentabilidade.

Ao tratar do financiamento público para projetos que tenham como efeito a observância e execução da Política Nacional sobre Mudança do Clima, dispõe o artigo $8^{\circ}$ que as instituições financeiras oficiais disponibilizarão linhas de crédito e financiamento específicas para desenvolver ações e atividades que tenham tal condão. Em paralelo e complementando as medidas de natureza tributária, das quais nos ocuparemos mais adiante, essas linhas de crédito e financiamento dedicadas ao estímulo às ações e atividades vinculadas aos objetivos da Política Nacional sobre Mudança do Clima têm papel fundamental para a busca da sustentabilidade como norte.

Interessante destacar, neste passo, que já se tem um eficiente parâmetro de orientação à implementação dessas linhas de crédito e financiamento. Trata-se de sistema de determinação de critérios para concessão de crédito, hoje já adotado por instituições financeiras públicas e privadas, no mundo todo, denominado de Princípios do Equador (orientados por parâmetros - guidelines, no inglês - estabelecidos pelo International Finance Corporation - IFC, entidade ligada ao Banco Mundial).

As instituições financeiras que aderem a tais Princípios (no Brasil, Itaú, Bradesco, Banco do Brasil, entre outras) submetem-se, grosso modo, a três critérios para definição da concessão - ou não - do crédito ao interessado: exclusões, salvaguardas e induções. Excluise dos potenciais beneficiados pela concessão de crédito aqueles empreendimentos cuja atividade esteja listada entre as excluídas pela instituição financeira (cada instituição signatária interpreta os critérios postos nos guidelines do IFC, e determina suas listas), ou cujos indicadores de risco não atinjam os índices mínimos de sustentabilidade determinados pela instituição financeira a partir da aplicação dos guidelines do IFC. 
Já no que tange às salvaguardas, concede-se o crédito, exigindo-se no entanto que o interessado atenda a critérios de sustentabilidade, controle e gestão de risco socioambiental que excedem aqueles ordinariamente estabelecidos pela lei (vê-se aqui, em cores fortes, o conceito antes defendido neste trabalho, de que a inserção da variável sustentabilidade na abordagem da questão ambiental retira à lei a condição de teto a ser observado para o trato do tema, passando-se a aplicar critérios outros, mais restritivos ou exigentes), com a exigência de estabelecimento de garantias e sob taxas de captação de recursos menos atraentes conforme seja mais alto o índice de risco medido para o empreendimento para o qual se pleiteia a concessão do crédito (um fator de desestímulo ao risco).

Por fim, as induções. A instituição financeira elege determinadas atividades, de perfil de risco reduzido, assim como estabelece critérios de classificação do risco medido, para atividades sob pleito de concessão de risco em geral, para as quais, dado o baixo índice de risco, concede-se o crédito com menor grau de exigência de garantias, e com melhores taxas de captação de recursos.

O conceito é simples: o custo de financiamento da atividade econômica será menor, conforme for menor o risco ambiental por ela criado. O exemplo e sucesso, portanto, já existe, e poderá ser adotado pelas instituições financeiras oficiais como parâmetro à definição dos critérios de concessão de crédito a serem aplicados para projetos que tenham como efeito a observância e execução da Política Nacional sobre Mudança do Clima: quanto mais vinculado aos objetivos de tal política for o projeto, menor o custo de captação dos recursos e menos intensas as exigências de constituição de garantias e as medidas adicionais à lei para controle ambiental e de emissões de GEE; e vice-versa.

\section{- a vinculação setorial}

O artigo 11 vincula outras políticas públicas à Política Nacional sobre Mudança do Clima, determinando que, por meio de Decreto do Poder Executivo, estabelecer-se-á

Planos setoriais de mitigação e de adaptação às mudanças climáticas visando à consolidação de uma economia de baixo consumo de carbono, na geração e distribuição de energia elétrica, no transporte público urbano e nos sistemas modais de transporte interestadual de cargas e passageiros, na indústria de transformação e na de bens de consumo duráveis, nas indústrias químicas fina e de base, na indústria de papel e celulose, na mineração, na indústria da construção civil, nos serviços de saúde e na agropecuária, com vistas em atender metas gradativas de 
redução de emissões antrópicas quantificáveis e verificáveis, considerando as especificidades de cada setor, inclusive por meio do Mecanismo de Desenvolvimento Limpo - MDL e das Ações de Mitigação Nacionalmente Apropriadas - NAMAs.

A relevância para o trabalho aqui proposto, neste dispositivo, reside no fato de incluir, entre os setores da economia sujeitos à intervenção qualitativa do Estado, para adoção de medidas de mitigação e de adaptação às mudanças climáticas visando à consolidação de uma economia de baixo consumo de carbono, os setores de geração e distribuição de energia elétrica e da agropecuária.

Diante desse dispositivo, fecha-se o ciclo normativo a justificar a pertinência do tema aqui escolhido: a Constituição Federal impõe a busca da sustentabilidade, observada a necessidade de abordagem intergeracional do trato da questão ambiental, e operando nosso país em cooperação com outros Estados, internalizando as regras a que adere no plano internacional, e com a adoção do tratamento diferenciado, para a intervenção do Estado na ordem econômica, visando a instrumentalizar a busca desses resultados (a sustentabilidade, em última análise); o alcance desse objetivo se operacionaliza, no que toca à mudança do clima, pela adoção de metas de redução de emissões de GEE, definidos setores específicos da economia como sujeitos a tais metas, dentre os quais o de geração e distribuição de energia elétrica, e o da agropecuária (que tem na intervenção sobre as florestas item crítico). O trato da implementação da Política Nacional sobre Mudança do Clima, nos setores de geração de energia elétrica, e no trato da proteção de nossas florestas, é pertinente, pois, à consecução dos princípios constitucionais invocados, e justifica este trabalho.

\section{- o veto aos artigos $4^{\circ}$, III, e 10, e a contraposição ao artigo 11 da Lei - efeitos e crítica}

Tema a ser tratado no tópico específico da implementação da Política Nacional sobre Mudança do Clima para o setor de geração e distribuição de energia elétrica, mas que importa desde já destacar, é que o veto Presidencial a alguns dos dispositivos da Lei $n^{\circ}$. 12.187/2009 toca à questão da busca da substituição do uso de combustíveis fósseis como fonte de energia em nosso sistema. Ao vetar os artigos $4^{\circ}$, III e 10 , da lei, assim se manifestou a Subchefia para Assuntos Jurídicos da Casa Civil da Presidência da República, por meio da Mensagem $n^{\circ}$. 1.123, de 29 de dezembro de 2009, aprovada pelo Presidente da 
República, que exerceu efetivamente o veto proposto (a Mensagem de veto incluiu o inciso VI do artigo $3^{\circ}$, que aqui se desconsidera pela impertinência para com o tema objeto deste trabalho):

Mensagem $\mathrm{N}^{\circ}$. 1.123, de 29 de dezembro de 2009.

Senhor Presidente do Senado Federal,

Comunico a Vossa Excelência que, nos termos do $\S 1^{0}$ do art. 66 da Constituição, decidi vetar parcialmente, por contrariedade ao interesse público e inconstitucionalidade, o Projeto de Lei $\mathrm{n}^{\circ}$. 18, de 2007 (n ${ }^{\circ} .283 / 09$ no Senado Federal), que "Institui a Política Nacional sobre Mudança do Clima - PNMC e dá outras providências".

(...)

Ouvido, também, o Ministério de Minas e Energia manifestou-se pelo veto aos seguintes dispositivos:

\section{Inciso III do art. $4^{\circ}$}

"Art. $4^{\mathrm{o}}$

III - ao estímulo ao desenvolvimento e ao uso de tecnologias limpas e ao paulatino abandono do uso de fontes energéticas que utilizem combustíveis fósseis;

\section{$\underline{\text { Razões do veto }}$}

"A atual política energética do País já tem priorizado a utilização de fontes de energia renováveis em sua matriz e obtido avanços amplamente reconhecidos no uso de tecnologias limpas. Uma das balizas dessa política é o aproveitamento racional dos vários recursos energéticos disponíveis, o que torna inadequada uma diretriz focada no abandono do uso de combustíveis fósseis. A estratégia para o setor deve atender aos princípios e objetivos estabelecidos pela Lei $\mathrm{n}^{\text {o. }} 9.478$, de 6 de agosto de 1997, que congrega a proteção ao meio ambiente a outros valores relevantes para a política e a segurança energéticas."

\section{$\underline{\text { Art. } 10}$}

"Art. 10. A substituição gradativa dos combustíveis fósseis, como instrumento de ação governamental no âmbito da PNMC, consiste no incentivo ao desenvolvimento de energias renováveis e no aumento progressivo de sua participação na matriz energética brasileira, em substituição aos combustíveis fósseis.

Parágrafo único. A substituição gradativa dos combustíveis fósseis será obtida mediante: 
I - o aumento gradativo da participação da energia elétrica produzida por empreendimentos de Produtores Independentes Autônomos, concebidos com base nas fontes eólicas de geração de energia, nas pequenas centrais hidrelétricas e de biomassa, no Sistema Elétrico Interligado Nacional;

II - o incentivo à produção de biodiesel, preferencialmente a partir de unidades produtoras de agricultura familiar e de cooperativas ou associações de pequenos produtores, e ao seu uso progressivo em substituição ao óleo diesel derivado de petróleo, particularmente no setor de transportes;

III - o estímulo à produção de energia a partir das fontes solar, eólica, termal, da biomassa e da co-geração, e pelo aproveitamento do potencial hidráulico de sistemas isolados de pequeno porte;

IV - o incentivo à utilização da energia térmica solar em sistemas para aquecimento de água, para a redução do consumo doméstico de eletricidade e industrial, em especial nas localidades em que a produção desta advenha de usinas termelétricas movidas a combustíveis fósseis;

V - a promoção, por organismos públicos de Pesquisa e Desenvolvimento científico-tecnológico, de estudos e pesquisas científicas e de inovação tecnológica acerca das fontes renováveis de energia;

VI - a promoção da educação ambiental, formal e não formal, a respeito das vantagens e desvantagens e da crescente necessidade de utilização de fontes renováveis de energia em substituição aos combustíveis fósseis;

VII - o tratamento tributário diferenciado dos equipamentos destinados à geração de energia por fontes renováveis;

VIII - o incentivo à produção de etanol e ao aumento das porcentagens de seu uso na mistura da gasolina;

IX - o incentivo à produção de carvão vegetal a partir de florestas plantadas."

\section{$\underline{\text { Razões do veto }}$}

"O dispositivo pretende indicar as formas de substituição dos combustíveis fósseis na matriz energética brasileira. Essa indicação, entretanto, não está adequadamente concatenada com as necessidades energéticas do País, o que pode fragilizar a confiabilidade e a segurança do sistema energético nacional.

Há que se destacar, por exemplo, que as diretrizes do dispositivo desconsideram a possibilidade de utilização de energia produzida a partir de centrais hidrelétricas, fonte que contribui sobremaneira para que a matriz energética brasileira esteja entre as mais limpas do mundo, além de constituir grande parte da geração de energia elétrica do País.

Assim, as diretrizes da PNMC e da Política Energética Nacional deverão ser harmonizadas de forma a proteger o meio ambiente e, ao mesmo tempo, garantir a segurança energética necessária para o desenvolvimento do País.” 
Essas, Senhor Presidente, as razões que me levaram a vetar os dispositivos acima mencionados do projeto em causa, as quais ora submeto à elevada apreciação dos Senhores Membros do Congresso Nacional.

Rico, para os fins deste trabalho, o veto presidencial aos dispositivos que pretendiam adotar como orientação da Política Nacional sobre Mudança do Clima a redução paulatina do uso dos combustíveis fósseis como fonte energética, até sua substituição por fontes renováveis.

Ao exercer o veto ao artigo 10 da Lei $\mathrm{n}^{\circ}$. 12.187/2009, negando submissão da Política Energética Nacional à Política Nacional sobre Mudança do Clima, o Presidente da República negou eficácia, em tese, ao artigo 11 da mesma lei, segundo o qual os princípios, objetivos, diretrizes e instrumentos das políticas públicas e programas governamentais deverão, sempre que for aplicável, compatibilizar-se com os princípios, objetivos, diretrizes e instrumentos da Política Nacional sobre Mudança do Clima.

O nó górdio para efetivamente se verificar o conflito, e a negativa de eficácia, pelo veto, ao referido artigo 11, encontra-se na expressão "sempre que for aplicável". Seria aplicável à Política Energética Nacional adequar-se aos princípios, objetivos, diretrizes e instrumentos da Política Nacional sobre Mudança do Clima? Na hipótese de ser afirmativa a resposta, concluir-se-á que, ao exercer o veto, sob os fundamentos invocados, teria o Presidente da República criado a situação sui generis sob a qual, para se dar aplicação plena ao artigo 11 da Lei $n^{\circ}$. 12.187/2009, que tem caráter geral, seria necessário desconsiderar-se o veto realizado ao texto específico ao setor de energia, posto no artigo 10, caput, da mesma lei.

Tal situação, confusa e indesejada, teria lugar em uma hipótese: ter a questão da substituição dos combustíveis fósseis, como fonte de geração de energia, papel fundamental no combate às emissões de GEE. Para tanto, algumas premissas devem ser consideradas.

A primeira premissa a considerar é a importância, em âmbito mundial, da contribuição do uso de combustíveis fósseis como fonte de energia para as emissões globais de GEE. A segunda premissa, igualmente fundamental, é a referente à importância de tal modo de geração de energia para o total das emissões de GEE pelo Brasil. Tomadas 
essas condições fáticas, e seu trato pelos instrumentos de âmbito internacional e internos a que se vincula o Brasil, no que toca à sua conduta diante da questão do combate à mudança do clima e seus efeitos, poder-se-á definir se, para efeitos de cumprimento do artigo 11 da Política Nacional sobre Mudança do Clima, será necessário adotar medidas para que a esta seja adequada a Política Energética Nacional.

No que toca à participação das emissões de GEE decorrentes da queima de combustíveis fósseis para a geração de energia, em escala mundial, verifica-se a inconteste relevância dessa matriz de emissões de GEE para o resultado global, já que representa valor superior a $60 \%$ do volume total de emissão de GEE no plano global. Vale dizer, a queima de combustíveis fósseis para a geração de energia é o maior vetor, em escala global, da emissão de GEE.

A consideração do alcance da chamada crise socioambiental, a que se refere Antonio Carlos Diegues ${ }^{64}$,

\begin{abstract}
não se trata simplesmente de uma crise natural, resultante da incapacidade dos ecossistemas de se reconstituírem após as intervenções danosas do homem moderno, mas de uma crise socioambiental, de civilização, que para sua superação exige uma alteração profunda não somente nos padrões científico-tecnológicos, mas também nos sistemas produtivos, nos valores consumistas e no uso de energia fóssil nas sociedades modernas.
\end{abstract}

Por essa razão é que tal fonte de emissões de GEE, a queima de combustíveis fósseis para geração de energia, recebe especial tratamento no âmbito da ConvençãoQuadro sobre Mudança do Clima.

Nesse contexto, tomada a vinculação brasileira aos princípios gerais de redução das emissões de GEE em escala mundial, adotados pela Convenção-Quadro sobre Mudança do Clima, e os fundamentos constitucionais (vide acima) que nos vinculam ao atendimento a tais princípios, acrescidos do fato de estarem tais termos, os da Convenção-Quadro Sobre Mudança do Clima, internalizados em nosso sistema (por meio do Decreto $\mathrm{n}^{\mathrm{o}}$. 1 , de 3.2.1994, e do Decreto 2.652, de 1.7.1998), forçosamente concluir-se-á que, no plano mundial, está - ou estaria - o Brasil vinculado a contribuir para a redução das emissões de

\footnotetext{
${ }^{64}$ DIEGUES, Antonio Carlos. A globalização da proteção da natureza: o papel das grandes ONGs transnacionais e da ciência. In: DUPAS, Gilberto (Org.). Meio ambiente e crescimento econômico: tensões estruturais. São Paulo: Ed. UNESP; Instituto de Estudos Econômicos e Internacionais, 2008. p. 131-132.
} 
GEE pela redução das emissões geradas pela queima de combustíveis fósseis para geração de energia, sendo esta fonte objeto de atenção central em tal cenário.

Difere a realidade do peso das emissões decorrentes da queima de combustíveis fósseis para o todo dessas emissões, quando tomado como universo o Brasil. Aqui, não caracteriza essa espécie de emissões de GEE um elemento relevante. Ao contrário, o percentual de colaboração da queima de combustíveis fósseis para o total de nossas emissões de GEE fica abaixo de $30 \%$.

Assim, se de um lado se tem a queima de combustíveis fósseis como um fator primordial para o volume de emissões de GEE, no plano global, essa realidade não se confirma no plano interno. E tal circunstância basta a validar o veto realizado, sem que daí decorra ofensa aos princípios, objetivos, diretrizes e instrumentos da Convenção-Quadro sobre Mudança do Clima e da Política Nacional sobre Mudança do Clima.

Não se ofende a Convenção-Quadro sobre Mudança do Clima porque, se de um lado vinculou-se o Brasil ao esforço internacional pelo combate às emissões de GEE, de outro lado, em nenhum momento, abrimos mão do direito soberano de definirmos a forma de implementação, internamente, das obrigações a que nos vinculamos (tal prerrogativa assiste a todos os Estados-parte da Convenção, naturalmente). Daí porque, atendido o objetivo de redução de nossas emissões de GEE, não caberá a nenhum dos Estados-parte da Convenção-Quadro sobre Mudança do Clima questionar a forma como alcançamos esse resultado, no que toca às políticas públicas adotadas, internamente, para tanto.

Cabe destacar que, guardadas as devidas proporções, no caso ora em exame muito menores, já se teve exemplo de negativa, por um Estado-parte da Convenção-Quadro sobre Mudança do Clima, de adesão a determinada regra, criada no âmbito desta, sob o argumento do risco que traria à economia desse Estado-parte. Trata-se da negativa, pelos Estados Unidos da América, a ratificar o Protocolo de Quioto, ocorrida em 2001. Ao fazêlo, o então Presidente daquele país, George W. Bush, invocou como razão a tanto o risco que traria tal instrumento à economia norte-americana, assim como destacou que os Estados Unidos da América poderiam assumir metas de redução de emissões de GEE desde que outros países, como a China, a Índia e o Brasil, também o fizessem.

$\mathrm{Na}$ mesma linha, ainda que em escala infinitamente menor, pois não nos estamos negando a cumprir um instrumento internacional ao qual aderimos, mas apenas 
direcionando as medidas internas para consecução de seus objetivos, aos quais permanecemos vinculados, andou o veto presidencial ao artigo 10 da Lei n ${ }^{\circ}$. 12.187/2009: invocando razões de ordem econômica sensíveis, excluiu-se do rol de medidas voltadas à redução de nossas emissões de GEE a substituição paulatina do uso de combustíveis fósseis na geração de energia.

Assim, não vemos no veto presidencial aos artigos $4^{\circ}$, III, e 10, da Lei $n^{\circ}$. 12.187/2009, ofensa à Convenção-Quadro sobre Mudança do Clima ou à Política Nacional sobre Mudança do Clima, em seu artigo 11. Preservamos o objeto central de ambos os instrumentos, que é a redução de nossas emissões de GEE, e não nos negamos a tratar das emissões geradas pelo setor de energia, e a integridade de ambos, que não se inviabilizam pela não substituição dos combustíveis fósseis como fonte de energia.

Naturalmente, isso não quer dizer que possamos, inadvertidamente, ampliar, sem controle, a participação percentual da queima de combustíveis fósseis em nosso volume de emissões de GEE, nem tampouco que possamos simplesmente deixar de atentar para o fato de que, nos últimos anos, temos assistido a uma "carbonização" de nossa matriz energética, o que traz consigo alguns riscos indesejáveis à competitividade de nossa economia.

Historicamente, baseamos nosso parque gerador elétrico na matriz hidráulica, que é, dentre as possíveis fontes de geração de energia elétrica, uma das menos impactantes, no que toca às emissões de GEE. Assim, podemos afirmar, como de fato se afirma, que nossa matriz elétrica é "limpa". Vem bem a propósito o que afirmavam, em 2002, Aspásia Camargo, João Paulo R. Capobianco e José Antonio Puppim ${ }^{65}$ de Oliveira acerca de nossa matriz energética:

\footnotetext{
"A matriz energética no Brasil costuma ser caracterizada de maneira geral como limpa.

(...)

Isso se deve principalmente ao peso da energia renovável na matriz brasileira, destacando-se a energia hidrelétrica e o uso de biomassa para fins energéticos."
}

Dados publicados pela Agência Nacional de Energia Elétrica - ANEEL demonstram que cerca de $75 \%$ de nossa matriz para tal fim é ainda hídrica. Ocorre que, nos últimos anos, o crescimento da oferta de energia gerada a partir da queima de combustíveis

\footnotetext{
${ }^{65}$ CAMARGO, Aspásia; CAPOBIANCO, João Paulo R.; OLIVEIRA, José Antonio Puppim de. Os desafios da sustentabilidade no período pós-Rio-92. In: (Orgs.). Meio ambiente Brasil: avanços e obstáculos pós-Rio-92. Rio de Janeiro: Fundação Getúlio Vargas, 2002. p. 30 e ss.
} 
fósseis tem alterado, já com algum peso, a realidade de nossa matriz de geração de energia elétrica. Chega já a algo em torno de $10 \%$ o percentual de nossa energia elétrica derivada da queima de combustíveis fósseis.

Nesse contexto, a se deixar de lado o trato dessa fonte de emissões de GEE, assumiremos o risco de (i) perdermos competitividade, diante da concorrência futura, pelo mercado, com produtos outros gerados a partir de matrizes limpas de energia, e que carregarão consigo, portanto, uma "pegada" de carbono menos intensa; e de (ii) vermos, em termos percentuais, a participação da queima de combustíveis fósseis para geração de energia crescer, percentualmente, em nosso volume total de emissões de GEE.

Daí por que, ainda que realizado o veto, não se nega que o Estado, no exercício da função de intervenção qualitativa na ordem econômica, possa lançar mão dos instrumentos constitucionalmente previstos, de forma a induzir um perfil de fontes alternativas, e não combustíveis fósseis, para os novos empreendimentos do setor de geração de energia a serem implantados em nosso sistema. O prestígio - estímulo, incentivo, ou ainda direcionamento da economia numa determinada direção - não significa, necessariamente, desprestígio a outros caminhos: estimular e incentivar o desenvolvimento do uso de uma determinada matriz energética não quer dizer inviabilizar outras. Esse o ponto a desenvolver.

Esse o contexto em que se deve considerar a questão da redução das emissões de GEE para o setor de energia: não se pode adotar como meta a substituição dos combustíveis fósseis como fonte de geração de energia, mas se pode - e, portanto, se deve - buscar o estímulo, incentivo e indução a que se desenvolvam fontes alternativas para geração de energia elétrica, para os novos empreendimentos. Sob essa ótica é que abordaremos o tema, mais adiante.

\section{- por fim, a meta assumida e sua natureza}

Por fim, do artigo 12 consta que, para alcance dos objetivos da Política Nacional sobre Mudança do Clima, o País adotará, como compromisso nacional voluntário, ações de mitigação das emissões de gases de efeito estufa, com vistas em reduzir entre 36,1\% (trinta e seis inteiros e um décimo por cento) e 38,9\% (trinta e oito inteiros e nove décimos por cento) suas emissões projetadas até 2020. 
Fundamental, aqui, tratar da questão da natureza obrigacional da meta assumida. Já se disse que, ao declarar a submissão brasileira a metas de redução de nossas emissões de GEE, nosso Presidente da República frisou o caráter voluntário de tal decisão, ou seja, sem vinculação a qualquer contrapartida por parte dos demais Estados-Parte da ConvençãoQuadro sobre Mudança do Clima como condição ao cumprimento de tal obrigação.

A reação da mídia, e especialmente de profissionais do Direito, naquele momento, foi de apego à natureza voluntária da obrigação assumida, como que a usando como garantia de ausência de riscos à sociedade brasileira, em caso de insucesso no atendimento a tal compromisso (excetuado, sempre, o risco de perda de credibilidade e posição de liderança nas negociações da Convenção-Quadro, risco este inafastável). Chegou-se a afirmar mesmo que caberia ao Estado brasileiro criar, no plano interno, medidas de estímulo para que os diversos setores da economia se vissem induzidos a adotar medidas adequadas à redução de nossas emissões de GEE, mas sem qualquer caráter impositivo.

Com todo respeito aos que assim pensam, nada mais equivocado. São totalmente diversas as relações entre o Brasil perante seus pares, no campo das relações internacionais, e as relações entre o Estado brasileiro e seus administrados.

Conforme defendido acima, feita a declaração de submissão a metas, pelo nosso mandatário maior, em Copenhagen [ainda que tal declaração não constitua, em tese e no plano formal, um dos instrumentos legítimos à vinculação em âmbito internacional, e que tenha natureza unilateral], alternativa não havia senão o estabelecimento de norma interna de mesmo teor, dada a teoria monista, que já se defendeu e adotou como adequada aqui, para vinculação de nossa sociedade aos compromissos adotados pelo Estado no plano internacional.

Assim, de uma banda, o compromisso [obrigação] unilateralmente adotado pelo Estado brasileiro, no âmbito das relações multilaterais entre Estados soberanos, caracterizase como voluntário por duas razões: a uma, porque não se vinculou a adoção de tal compromisso [obrigação] a qualquer contrapartida pelos demais Estados-parte da Convenção-Quadro sobre Mudança do Clima; e, a duas, porquanto não sujeita o Estado brasileiro a qualquer tipo de penalidade em caso de descumprimento do quanto assumido, salvo a perda de credibilidade e liderança - perdas portanto de ordem moral - nas negociações no âmbito da Convenção-Quadro sobre Mudança do Clima. 
Não é dessa forma, no entanto, no que concerne à relação entre o Estado brasileiro e seus administrados. Ao afirmar, no plano das relações entre Estados soberanos, seu compromisso de redução de emissões de GEE, o Estado brasileiro vinculou a essa promessa [obrigação] toda a sociedade brasileira. Isto porque, quando se manifesta em nome do Estado brasileiro, o faz nosso Governo em nome e por mandato da sociedade como um todo.

Para cumprir seu compromisso [obrigação] perante seus pares, depende o Estado brasileiro que as medidas a serem adotadas para tanto o sejam pela sociedade brasileira. E essa relação, entre Estado e sociedade, a partir do momento em que se adota metas a serem atingidas, como compromisso do Estado, não pode ser tratada no âmbito da voluntariedade: passa a constituir relação de ordem mandatória, obrigacional mesmo, não sendo dado aos setores da sociedade e seus agentes econômicos furtarem-se ao seu cumprimento, sob pena de imposição de sanções. Até porque, se não impostas as metas de forma mandatória, e com a previsão de sanções aos inadimplentes, dificilmente se verá cumprimento aos seus números. Verifica-se aqui a lição de Kelsen: não existe norma sem sanção ${ }^{66}$.

Daí por que, se no plano das relações internacionais, entre Estados soberanos, o compromisso adotado pelo Brasil caracteriza-se como voluntário, não é assim no plano interno, no que toca à relação entre o Estado e seus administrados, na implementação, por meio da Política Nacional sobre Mudança do Clima, dessas metas e objetivos.

Tão logo regulamentada a Política Nacional sobre Mudança do Clima, aplicados os instrumentos ali criados, tornar-se-ão vinculantes para a sociedade as metas e objetivos determinados, sujeitando-se o infrator às sanções estabelecidas.

\section{(ii) o Decreto $\mathrm{n}^{\circ}$. 7.390, de 9.12.2010}

O Decreto $n^{\circ}$. 7.390, publicado em 9.12.2010, regulamentou os artigos $6^{\circ}, 11$ e 12 da Lei $n^{\circ}$. 12.187. Alguns dos dispositivos desse Decreto são de relevância ao trabalho aqui desenvolvido, por tratar diretamente da implementação da Política Nacional sobre Mudança do Clima, no que toca aos setores de geração e distribuição de energia elétrica ou ao setor agropecuário; e outros, porquanto tratam de temas gerais da Política Nacional sobre Mudança do Clima, que podem ou efetivamente afetarão esses setores.

\footnotetext{
${ }^{66}$ Vide KELSEN, Hans. Teoria geral do direito e do Estado. 3. ed. São Paulo: Martins Fontes, 2000.
} 
No artigo $2^{\circ}$ vem já a menção expressa à questão do desmatamento:

Art. $2^{\circ} \mathrm{O}$ Plano Nacional sobre Mudança do Clima será integrado pelos planos de ação para a prevenção e controle do desmatamento nos biomas e pelos planos setoriais de mitigação e de adaptação às mudanças climáticas, de que tratam, respectivamente, os arts. $6^{\circ}$ e 11 da Lei ${ }^{\circ}$. 12.187, de 2009.

Ainda que nos pareça ociosa essa expressa menção ao desmatamento, porquanto, conforme já afirmamos antes neste trabalho, o trato do setor agropecuário passa invariavelmente pelo trato das queimadas e desmatamento, é salutar ver a menção, para espancar qualquer dúvida de que nossa Política Nacional sobre Mudança do Clima deve ocupar-se do desmatamento (no Decreto, referido de forma genérica, o que inclui o desmatamento realizado por meio de queimadas). $\mathrm{O}$ artigo $3^{\circ}$ reforça essa constatação, ao tratar dos planos a serem considerados para a busca do controle do desmatamento:

Art. $3^{\circ}$ Para efeito da presente regulamentação, são considerados os seguintes planos de ação para a prevenção e controle do desmatamento nos biomas e planos setoriais de mitigação e de adaptação às mudanças climáticas:

I - Plano de Ação para a Prevenção e Controle do Desmatamento na Amazônia Legal - PPCDAm;

II - Plano de Ação para a Prevenção e Controle do Desmatamento e das Queimadas no Cerrado - PPCerrado;

III - Plano Decenal de Expansão de Energia - PDE;

IV - Plano para a Consolidação de uma Economia de Baixa Emissão de Carbono na Agricultura; e

V - Plano de Redução de Emissões da Siderurgia.

Pelo inciso III do artigo $3^{\circ}$ percebe-se que, ao tratar da redução do desmatamento, a Política Nacional impõe, por via oblíqua, a interação com a Política Energética Nacional, já que esta, ao considerar o Plano Decenal de Expansão de Energia, necessariamente terá de tomar em conta sua participação na redução do desmatamento no país.

As projeções de emissões de GEE para os setores-chave a serem considerados na implementação de medidas vêm indicadas no artigo $5^{\circ}$, ao passo que, no artigo $6^{\circ}$, verificase as medidas a serem implementadas: 
Art. $5^{\circ}$ A projeção das emissões nacionais de gases do efeito estufa para o ano de 2020 de que trata o parágrafo único do art. 12 da Lei $\mathrm{n}^{\circ}$. 12.187, de 2009, é de 3.236 milhões tonCO $\mathrm{C}_{2}$ eq de acordo com detalhamento metodológico descrito no Anexo deste Decreto, composta pelas projeções para os seguintes setores:

I - Mudança de Uso da Terra: 1.404 milhões de tonCO ${ }_{2}$ eq;

II - Energia: 868 milhões de tonCO ${ }_{2}$ eq;

III - Agropecuária: 730 milhões de tonCO $\mathrm{CO}_{2} \mathrm{eq}$; e

IV - Processos Industriais e Tratamento de Resíduos: 234 milhões de tonCO $\mathrm{C}_{2}$ eq.

Art. $6^{\circ}$ Para alcançar o compromisso nacional voluntário de que trata o art. 12 da Lei $\mathrm{n}^{\circ}$ 12.187, de 2009, serão implementadas ações que almejem reduzir entre 1.168 milhões de ton $\mathrm{CO}_{2}$ eq e 1.259 milhões de tonCO $\mathrm{C}_{2}$ eq do total das emissões estimadas no art. $5^{\mathrm{o}}$.

$\S 1^{\underline{0}}$ Para cumprimento do disposto no caput, serão inicialmente consideradas as seguintes ações contidas nos planos referidos no art. $3^{\circ}$ deste Decreto:

I - redução de oitenta por cento dos índices anuais de desmatamento na Amazônia Legal em relação à média verificada entre os anos de 1996 a 2005;

II - redução de quarenta por cento dos índices anuais de desmatamento no Bioma Cerrado em relação à média verificada entre os anos de 1999 a 2008;

III - expansão da oferta hidroelétrica, da oferta de fontes alternativas renováveis, notadamente centrais eólicas, pequenas centrais hidroelétricas e bioeletricidade, da oferta de biocombustíveis, e incremento da eficiência energética;

IV - recuperação de 15 milhões de hectares de pastagens degradadas;

V - ampliação do sistema de integração lavoura-pecuária-floresta em 4 milhões de hectares;

VI - expansão da prática de plantio direto na palha em 8 milhões de hectares;

VII - expansão da fixação biológica de nitrogênio em 5,5 milhões de hectares de áreas de cultivo, em substituição ao uso de fertilizantes nitrogenados;

VIII - expansão do plantio de florestas em 3 milhões de hectares;

IX - ampliação do uso de tecnologias para tratamento de 4,4 milhões de $\mathrm{m}^{3}$ de dejetos de animais; $\mathrm{e}$

X - incremento da utilização na siderurgia do carvão vegetal originário de florestas plantadas e melhoria na eficiência do processo de carbonização. 
Os incisos do artigo $6^{\circ}$ destacados em negrito são aqueles que tocam aos setores eleitos, para fins deste trabalho, para análise. Vê-se que a redução das emissões de GEE, no setor de florestas (leia-se, aqui, a integração destas com todos os setores que afetam ou valem-se das florestas, notadamente o setor agropecuário), é foco central, e que o setor de energia demanda a criação de mecanismos que garantam ganho de competitividade às fontes alternativas de geração de energia.

Definidas as metas para os setores a serem considerados neste trabalho, e as ações voltadas à consecução dessas metas, resta verificar outras ferramentas legais que toquem a tais setores, e que, de forma positiva ou negativa, tenham ou possam ter influência sobre a capacidade de atendimento às metas em questão.

\section{- Florestas - a legislação e as propostas em trâmite, de interface direta ou indireta}

Para o setor de florestas, o exame aqui proposto, da legislação de interface direta ou indireta com os princípios, objetivos, diretrizes e instrumentos da Política Nacional sobre Mudança do Clima, ater-se-á aos dois principais instrumentos legais vigentes, quais sejam, o Código Florestal e o Sistema Nacional de Unidades de Conservação, e aos dois instrumentos que, em debates na Casa Legislativa, propõem relevantes inovações e agregam muito valor ao ordenamento, vinculadas que vêm aos novos princípios e paradigmas da questão ambiental, nos planos fático e do Direito. Trata-se dos projetos de lei por meio dos quais se pretende (i) fomentar e regulamentar o mercado de REDD+ no Brasil, antecipando nosso sistema à institucionalização desse mecanismo no plano da Convenção-Quadro sobre Mudança do Clima; e (ii) definir e disciplinar a questão do pagamento por serviços ambientais, ferramenta vinculada ao princípio do protetor-recebedor.

(iii) o Código Florestal

(iv) o Sistema Nacional de Unidades de Conservação - SNUC

(v) o Projeto de Lei $n^{\circ} .195 / 11$, que regulamenta o mercado de REDD+

(vi) o Projeto de Lei $n^{\circ}$. 309/2010, que disciplina o pagamento por serviços ambientais

Passemos ao exame de cada um desses marcos. 


\section{(iii) o Código Florestal}

Estabelecido originariamente em 1934, e depois substituído pela Lei $\mathrm{n}^{\circ}$. 4.771, de 15.9.1965, o Código Florestal traz, no que concerne ao objeto deste trabalho, contribuição essencial para a consecução de nossas metas de redução do desmatamento e, por consequência, de nossas emissões de GEE. Trata-se dos institutos da Reserva Legal - RL e da Área de Preservação Permanente - APP, criados para garantir a mantença de uma porção de nosso território sob proteção legal, de forma a se ter a conservação de áreas (i) representativas de nossos biomas; e (ii) que desempenham função de relevância ambiental na proteção de bens ambientais tais como nossos recursos hídricos.

Tais institutos, que vêm em linha com o que determina o artigo $2^{\circ}$ da Convenção sobre a Diversidade Biológica, que estabelece que área protegida é aquela "definida geograficamente que é destinada, ou regulamentada, e administrada para alcançar objetivos específicos de conservação."

Estabelecida pelo artigo $1^{\circ}, \S 2^{\circ}$, III, Reserva Legal é a área localizada no interior de uma propriedade ou posse rural, excetuada a de preservação permanente, necessária ao uso sustentável dos recursos naturais, à conservação e reabilitação dos processos ecológicos, à conservação da biodiversidade e ao abrigo e proteção de fauna e flora nativas.

Entendida inicialmente como uma restrição de ordem administrativa ao direito de propriedade, a Reserva Legal é vista hoje como um elemento de constituição do direito de propriedade em si, por meio do qual se dedica parcela da propriedade rural à conservação ambiental.

Em termos práticos, o proprietário rural deixa de ter a faculdade de aproveitar economicamente parte de sua propriedade, assumindo ainda o ônus de manutenção e garantia de conservação da parcela dedicada à conservação, posto que aplicáveis sanções de ordem administrativa, civil e até mesmo penal, em caso de descumprimento da obrigação de conservação.

Já no tocante à Área de Preservação Permanente, assim pontua o Código Florestal ao defini-la, no artigo $1^{\circ}$, $\S 2^{\circ}$, II: área protegida nos termos dos arts. $2^{\circ}$ e $3^{\circ}$ desta Lei, coberta ou não por vegetação nativa, com a função ambiental de preservar os recursos hídricos, a paisagem, a estabilidade geológica, a biodiversidade, o fluxo gênico de fauna e 
flora, proteger o solo e assegurar o bem-estar das populações humanas; (Incluído pela Medida Provisória no. 2.166-67, de 2001).

Conforme se vê da definição legal, presta-se a APP a garantir, por meio da preservação de determinadas áreas, nas quais se insere determinada vegetação, a realização de uma função ecológica, para a consecução da qual é indispensável a existência da vegetação em questão.

Também aqui, em nome de um resultado positivo em termos de conservação ambiental, deixa o proprietário de poder explorar parcela de seu imóvel, respondendo pelos ônus de manutenção e conservação de tal área, dado também aqui incidirem sanções de ordem administrativa, civil e penal, se não conservada e mantida a área onerada. Daí decorre, portanto, que a APP, a exemplo da Reserva Legal, corresponde a um custo ambiental oponível à propriedade.

Em ambos os casos, a lógica econômica é clara: ao se adquirir uma determinada propriedade, o adquirente deve estar ciente de que assumirá um custo ambiental, por força do qual parcela de seu imóvel não poderá ser explorada, apresentando ainda um custo para sua manutenção. Trata-se de um custo que incide sobre a propriedade, como forma de viabilização do cumprimento de sua função socioambiental ${ }^{67}$ e de sua exploração econômica regular.

A interação entre esses instrumentos de cunho preservacionista e o interesse do uso da maior extensão possível de terras para a produção pelo agronegócio gerou em nosso país uma dicotomia e um conflito que, ao período em que se elaborava este trabalho, polêmica e debates acalorados proporcionaram. Não se vai aqui discutir as razões de um lado e de outro no debate, já que não é esse o foco deste trabalho. Ater-nos-emos a um aspecto específico: com a provável aprovação do novo texto do Código Florestal, afirma-se que parte das áreas que até então vinham sob proteção legal deixam de gozar de tal privilégio, restando desimpedidas para uso pelo agronegócio.

\footnotetext{
${ }^{67}$ FIGUEIREDO, Guilherme José Purvin de; LEUZINGER, Márcia Dieguez. Desapropriações ambientais na Lei 9.985/2000. In: BENJAMIN, Antonio Herman (Coord.). Direito ambiental das áreas protegidas: o regime jurídico das unidades de conservação. Rio de Janeiro: Forense Universitária, 2001. p. 472, dizem a respeito da interação da questão ambiental com a propriedade privada: "Assim, a função social, que impõe ao proprietário a preservação do meio ambiente, nos moldes estabelecidos em lei, impõe limites internos ao exercício do direito de propriedade, independentemente da vontade do particular, limites estes que, na maioria das vezes, sequer são indenizáveis."
} 
Conforme trabalho técnico realizado por Gustavo Tosello Pinheiro, a alteração estabelecida pelo novo texto do Código Florestal, em vias de ser aprovado por nossa Casa Legislativa, o resultado físico das alterações propostas será de liberação para exploração econômica de 29,6 milhões de hectares de áreas degradadas que, pelo texto vigente do diploma florestal, são consideradas áreas degradadas sujeitas a recuperação/regeneração. Por outras palavras, volume de 29,6 ha. de áreas que seriam restauradas não mais o serão.

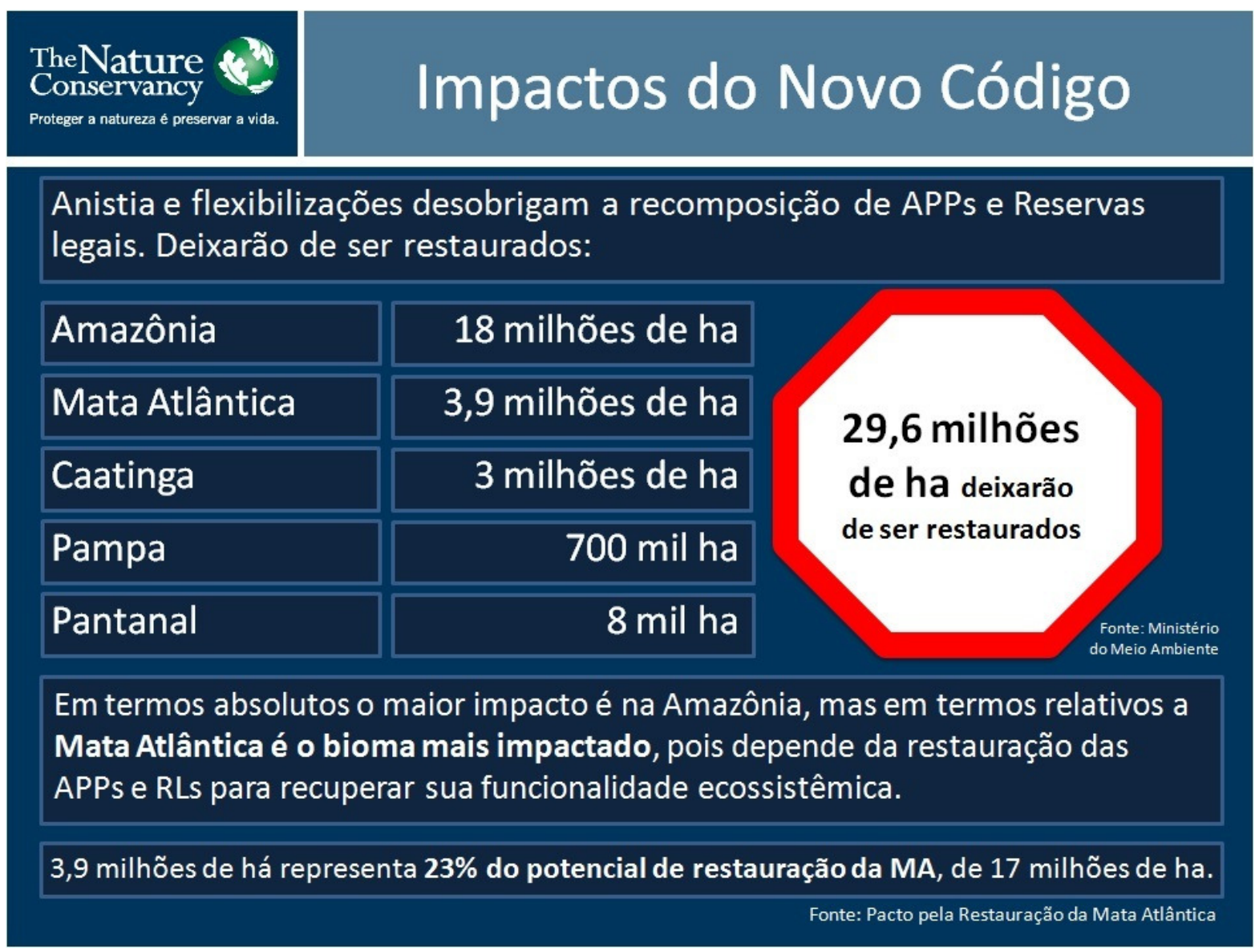

Fonte: apresentação de Gustavo Pinheiro em reunião do Conselho Consultivo da The Nature Conservancy TNC no Brasil, em 7 dez. 2011

Abstraído o debate acerca do acerto ou equívoco da alteração proposta para o Código Florestal, o ponto que releva aqui, para o exercício que se está a desenvolver, é o de que, em termos práticos, verifica-se redução do volume de áreas a serem restauradas de nossas florestas. O efeito deste fato sobre nossa habilidade para cumprirmos outras políticas públicas ambientais transversais ao Código Florestal é o ponto que examinaremos mais além. 


\section{(iv) o Sistema Nacional de Unidades de Conservação - SNUC}

Instrumento outro integrante do rol de diplomas legais integrantes da política florestal em nosso país é a Lei $\mathrm{n}^{\circ}$. 9.985, de 18.7.2000, por meio da qual instituiu-se o Sistema Nacional de Unidades de Conservação - SNUC. O fundamento constitucional que informa tal lei é o artigo 225, $\S 1^{\circ}$, III, que estabelece caber ao Poder Público, no mister de defender e preservar o meio ambiente para as presentes e futuras gerações, definir, em todas as unidades da Federação, espaços territoriais e seus componentes a serem especialmente protegidos, sendo a alteração e a supressão permitidas somente através de lei, vedada qualquer utilização que comprometa a integridade dos atributos que justifiquem sua proteção.

$\mathrm{Na}$ forma do artigo $2^{\circ}$ da Lei $\mathrm{n}^{\circ}$. 9.985/2000, assim se define unidade de conservação: espaço territorial e seus recursos ambientais, incluindo as águas jurisdicionais, com características naturais relevantes, legalmente instituído pelo Poder Público, com objetivos de conservação e limites definidos, sob regime especial de administração, ao qual se aplicam garantias adequadas de proteção.

As unidades de conservação poderão ser de duas espécies: uso sustentável, nas quais se admite o desenvolvimento de determinadas atividades sustentáveis, e de proteção integral, nas quais o nível de restrição à interação e intervenção humana é mais acentuado. Em qualquer hipótese, efeito imediato e inevitável da afetação de espaços territoriais à proteção ambiental, por meio das Unidades de Conservação, é a restrição ao seu uso para o desenvolvimento de atividades da produção econômica.

Para algumas das Unidades de Conservação, adicionalmente, é condição transferirse o espaço territorial afetado pela proteção legal à posse e domínio públicos, onerando-se sobremaneira o Estado pela sua afetação à proteção ambiental.

Tomando-se a Amazônia Legal, pode-se perceber a importância das Unidades de Conservação na formação do mosaico de proteção ambiental: 


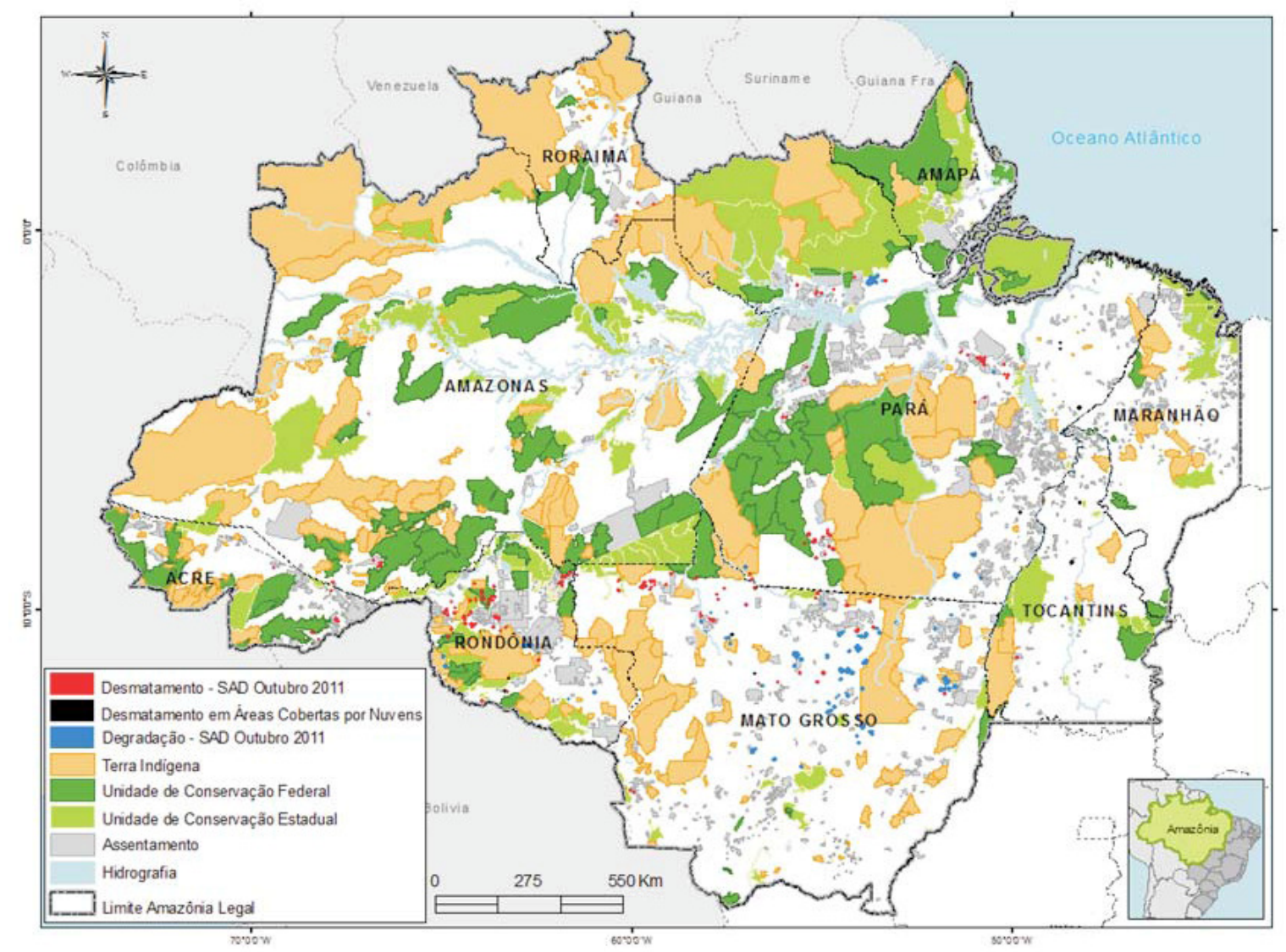

Fonte: Transparência Florestal - Amazônia Legal - IMAZON - out. 2011.

Disponível em: <www.imazon.org.br>

O custo de criação, manutenção e operação das Unidades de Conservação, desnecessário destacar, é imenso. Para seu custeio, instituiu-se, por meio do artigo 36 da Lei $n^{o}$. 9.985/2000, a figura da compensação ambiental, instrumento polêmico, que gerou intensos debates. A constitucionalidade da compensação ambiental restou reconhecida pelo Supremo Tribunal Federal (na ADIn 3.378-6), não obstante sua aplicação prática ainda gere debates acalorados, dada a prerrogativa entregue ao Estado para que fixe, caso a caso, o valor a ser desembolsado pelo empreendedor a título de compensação pelos impactos não evitados de sua intervenção - de significativo impacto ambiental - sobre o meio ambiente.

Ocorre que tal instrumento apresenta dois aspectos dissociados da tese que aqui se pretende demonstrar: a uma, origina-se a compensação ambiental da incapacidade dos sistemas de controle e proteção ambiental em obter a neutralização dos impactos ambientais decorrentes da intervenção humana para fins de desenvolvimento de atividades produtivas. Resposta que é, portanto, a um impacto que não se consegue evitar, a uma externalidade negativa que à sociedade caberá suportar, revela-se a compensação ambiental 
como um instrumento de imposição de "penalidade" pelo impacto não evitado, situando-se no campo das medidas materializadoras do princípio do poluidor-pagador.

A duas, ao tratar de forma reativa e indireta dos impactos residuais não neutralizados do empreendimento previsto e licenciado, sem realizar tal exercício visando induzir uma nova postura do empreendedor diante do risco de sua atividade, a compensação ambiental deixa de ter - e a nosso ver não só poderia, como deveria ter caráter indutivo, de orientação da sociedade e do capital em direção a posturas mais sustentáveis.

Ocorre que a compensação ambiental não gerou, pela sua aplicação, recursos suficientes ao custeio de todas as Unidades de Conservação de nosso país, sendo notório o abandono e deterioração de vários dos espaços territoriais afetados pelo instituto das Unidades de Conservação.

Assim, seja em razão da falta de recursos materiais e humanos, seja em razão da dificuldade de acesso e fiscalização, em parcela significativa das áreas submetidas ao regime das Unidades de Conservação verifica-se ocupação e uso irregulares, prejudicandose o resultado conservacionista pretendido quando de sua afetação ao regime legal.

\section{(v) o Projeto de Lei $n^{\circ}$. 195/11, que regulamenta o mercado de REDD+}

Após o estabelecimento do Protocolo de Quioto, em 1997, e sua entrada em vigor, já em 2005, as discussões no âmbito da Conferência das Partes - COP da ConvençãoQuadro sobre Mudança do Clima conheceram novo rumo quando, em 2005, por ocasião da COP em Montreal, um grupo de países que se autodenominou de Coalizão das Florestas Tropicais propôs a discussão de mecanismo de remuneração pela preservação de estoques de carbono gerados pela manutenção de áreas florestadas.

De lá a esta data, sendo a COP de Durban, realizada em dezembro de 2011 o último andamento, não se definiu, no plano internacional, um instrumento que absorva o conceito do estoque de carbono fixado pelas florestas como objeto de mecanismos econômicos. $\mathrm{O}$ REDD+ é ainda, no plano da Convenção-Quadro sobre Mudança do Clima, algo a resolver e tornar institucional. 
A ausência de um instrumento institucional de alcance internacional, no entanto, não impede que, no plano interno, cuidemos de nosso interesse em reduzir as emissões de GEE decorrentes do desmatamento e degradação de florestas, elementos que, conforme já destacado neste trabalho, constituem a principal fonte de emissões de GEE brasileira.

Inicialmente levado à Câmara dos Deputados, Projeto de Lei para regulamentação do REDD+ no nosso país foi arquivado com o final da legislatura encerrada em 2010, dado não ter ocorrido a reeleição de seu proponente.

Com apoio do Senador Eduardo Braga, no entanto, em 8.2.2011 a Deputada Rebecca Garcia novamente submeteu a ideia à consideração de nossa Casa Legislativa, propondo por meio do PL 195/11 que se institua o sistema nacional de redução de emissões por desmatamento e degradação, conservação, manejo florestal sustentável, manutenção e aumento dos estoques de carbono florestal (REDD+).

$\mathrm{Na}$ forma do PL apresentado, em sua versão última, que tramita perante nossa Casa Legislativa, cria-se um mercado de REDD+ no Brasil, por meio do qual (i) se regula os projetos a tal mecanismo referentes, no que tange às áreas elegíveis, à relevantíssima repartição de benefícios, e à alocação de seus resultados, ponto outro que reputamos fundamental.

Nada obstante entendermos que o PL ainda reclama complementações, insta ressaltar, para o que interessa ao tema deste trabalho, que a ideia de regulamentação do mercado interno de REDD+ merece aplauso, dado contribuir, tal instrumento, para a inversão da lógica econômica da Reserva Legal, da APP e das UCs, conforme destacaremos mais adiante: o que é custo/despesa torna-se fonte de receita/auto-custeio.

(vi) o Projeto de Lei $n^{0}$. 309/2010, que disciplina o pagamento por serviços ambientais

Em paralelo e somando-se à iniciativa de regulamentação de um mercado interno de REDD+, nossa Casa Legislativa vem apreciando o PL 309/2010, que estabelece a Política Nacional de Bens e Serviços Ambientais e Ecossistêmicos - PNBASAE.

A dinâmica proposta nessa lei é a de reconhecimento do valor - econômico - que têm os serviços ambientais e ecossistêmicos, atribuindo-se retribuição, monetária ou não, às atividades humanas de restabelecimento, recuperação, manutenção e melhoria dos 
ecossistemas que geram bens e serviços ambientais, e também aqueles que estejam amparados por planos, programas e subprogramas específicos (artigo $3^{\circ}$, IV).

Aqui, portanto, a exemplo do que se vê na proposta do PL do REDD+, o que se pretende criar é um elemento de inversão da lógica econômica para a reserva legal e a APP (e também a UC), pela atribuição de valor econômico a um bem ou serviço que, antes, não recebia valoração pela cadeia de produção econômica.

Ainda sob a forma de PL, o instrumento encontra tímida aplicação voluntária, sob regras específicas, não se podendo afirmar que há um efetivo mercado envolvendo os serviços ambientais e ecossistêmicos.

Interessante notar, neste passo, que o PL 1.274/2011 propõe a criação de instrumentos para custeio do pagamento por serviços ambientais, a partir da instituição do Fundo Federal de Pagamento por Serviços Ambientais, que receberia recursos, entre outros, da compensação financeira de que trata a Lei $n^{\circ} 7.990$, de 28.12.1989. Essa lei regulamenta a compensação financeira a que fazem jus órgãos da administração direta da União, Estados, Distrito Federal e municípios, na forma do artigo 20, $\S 1^{\circ}$, da Constituição Federal, em razão da exploração de petróleo ou gás natural, de recursos hídricos para fins de geração de energia elétrica e de outros recursos minerais no respectivo território, plataforma continental, mar territorial ou zona econômica exclusiva.

O STF, em decisão que reputamos lapidar, decidiu, ao examinar a natureza jurídica dessa compensação financeira, que os recursos dela advindos devem ser aplicados pelos seus beneficiários no trato dos efeitos e impactos de ordem ambiental, social e econômica, decorrentes da atividade sujeita ao pagamento da compensação (RE 228.800, relatado pelo Ministro Sepúlveda Pertence, em 24.9.2001, Primeira Turma, publicado no DJ em 16.11.2001 PP-00021).

O mérito do PL 1.274/2011 é o de propor a criação de um Fundo para custeio do pagamento por serviços ambientais e apontar-lhe a fonte de recursos, não trazendo pois uma proposta sem lastro. Chama a atenção a Justificativa do PL, no ponto em que destaca a mudança de paradigma na atuação do Estado, abandonando o perfil de repressor, na busca do atingimento de seus objetivos conservacionistas, para adotar perfil de incentivador às posturas de tal matiz: 
Por muito tempo, o legislador brasileiro pretendeu proteger o meio ambiente apenas penalizando seus detratores. Atualmente, sobretudo em face da ineficiência da legislação repressiva, torna-se indispensável recorrer a outros mecanismos que subsidiem o combate à degradação ambiental. Não basta punir o agressor. É conveniente aliar a isso estratégias que também premiem os que agem corretamente, de modo a fortalecer o contingente dos que propugnam pela defesa de nossas riquezas naturais e por melhor qualidade de vida das atuais e próximas gerações. Essa é a intenção do projeto.

Bem se vê, já se começa a buscar, no setor florestal, a inversão de paradigmas que pregamos como vetor de aprimoramento e consolidação de nosso sistema de comando e controle. O foco do PL 1.274/2011, no entanto, ainda é pontual, ou seja, de criação de benefícios aos agentes que adotarem posturas voluntárias em favor do meio ambiente. Não se altera políticas públicas pela aplicação transversal de políticas outras, de perfil ambiental. Nossa proposta, veremos mais adiante, adota essa premissa: ao invés de propormos a incidência de um mecanismo que incentive o contribuinte a uma postura, individual, de cunho conservacionista, apontamos nossos esforços para a consideração transversal de políticas públicas de cunho ambiental (a Política Nacional sobre Mudança do Clima) sobre políticas outras, como no caso, a Política Energética Nacional, de um lado, e a Política Florestal, de outro.

\section{- o setor de energia}

No tocante ao setor de energia, o exame que nos propomos a realizar toca à estrutura de formação e ampliação do parque de geração de energia elétrica no Brasil. Para tanto, entendemos relevante, e de implicação direta ou indireta ao tema da implementação dos objetivos e metas da Política Nacional sobre Mudança do Clima, a indicação e análise da Política Energética Nacional; do Plano Decenal de Expansão de Energia; e da estrutura de contratação de energia pelo Estado, por meio da ANEEL, para que se entenda a estrutura de atratividade ao capital de investimento, nesse setor, viabilizando a identificação, mais adiante neste trabalho, das medidas eficazes para intervenção qualitativa do Estado na ordem econômica, obtendo-se assim a indução e estímulo à expansão do uso de matrizes alternativas, ditas limpas, para a geração de energia e ampliação da oferta. 


\section{(vii) a Política Energética Nacional}

Estabelecida pela Lei nº.9.478, de 6.8.1997, a política energética nacional, na busca do aproveitamento racional das fontes de energia como mote central (conforme define o artigo $1^{\circ}$ ), traz, entre seus objetivos, os seguintes itens, que dizem respeito diretamente ao tema deste trabalho:

I - preservar o interesse nacional;

II - promover o desenvolvimento, ampliar o mercado de trabalho e valorizar os recursos energéticos;

III - proteger os interesses do consumidor quanto a preço, qualidade e oferta dos produtos;

IV - proteger o meio ambiente e promover a conservação de energia;

$(\ldots)$

VII - identificar as soluções mais adequadas para o suprimento de energia elétrica nas diversas regiões do País;

VIII - utilizar fontes alternativas de energia, mediante o aproveitamento econômico dos insumos disponíveis e das tecnologias aplicáveis;

IX - promover a livre concorrência;

$\mathrm{X}$ - atrair investimentos na produção de energia;

$(\ldots)$

XII - incrementar, em bases econômicas, sociais e ambientais, a participação dos biocombustíveis na matriz energética nacional. (Redação dada pela Lei $n^{\circ}$. 11.097, de 2005)

XIII - garantir o fornecimento de biocombustíveis em todo o território nacional; (Incluído pela Lei ${ }^{\circ}$. 12490, de 2011)

XIV - incentivar a geração de energia elétrica a partir da biomassa e de subprodutos da produção de biocombustíveis, em razão do seu caráter limpo, renovável e complementar à fonte hidráulica; (Incluído pela Lei $\mathrm{n}^{\circ} .12490$, de 2011)

XV - promover a competitividade do País no mercado internacional de biocombustíveis; (Incluído pela Lei $\mathrm{n}^{\circ}$. 12490, de 2011)

XVI - atrair investimentos em infraestrutura para transporte e estocagem de biocombustíveis; (Incluído pela Lei $\mathrm{n}^{\circ}$. 12490, de 2011)

XVII - fomentar a pesquisa e o desenvolvimento relacionados à energia renovável; (Incluído pela Lei n ${ }^{\circ}$. 12490, de 2011)

XVIII - mitigar as emissões de gases causadores de efeito estufa e de poluentes nos setores de energia e de transportes, inclusive com o uso de biocombustíveis. (Incluído pela Lei $\mathrm{n}^{\circ}$. 12490, de 2011) 
Do rol de objetivos da Política Energética Nacional destacados, verifica-se a coexistência da variável econômica, ligada ao desenvolvimento, à livre iniciativa, ao direito dos cidadãos ao menor preço, à atração de investimentos para o setor, e à universalização do fornecimento de energia, temas de ordem econômica, que são conjugados com objetivos outros, de ordem ambiental, tais como o de proteger o meio ambiente e promover a conservação de energia, garantir o uso de fontes alternativas para a produção de energia, e para se reduzir as emissões de GEE.

No que tange ao setor de energia elétrica, o exame de sua estrutura impõe prévio exame, ainda que superficial, de seu histórico, para que se possa então compreender sua estrutura e mecanismos atuais.

Para o exame do histórico deste delicado e peculiar setor da economia, lançamos mão aqui, primordialmente, de duas fontes de pesquisa, nas quais buscamos os elementos necessários à exposição que se põe a seguir. De um lado, valemo-nos de excepcional trabalho elaborado por José Roberto Oliva Junior ${ }^{68}$, que tomamos como linha mestra, e de obra festejada, de Maurício Tolmasquim, em que o autor examina em detalhe o denominado "Novo Modelo do Setor Elétrico Brasileiro".

Oliva Jr. inicia o exame do desenvolvimento histórico do setor por destacar que a perda de eficiência operacional, ocorrida a partir da década de 70 , deveu-se à adoção de uma política de equalização de tarifas que, fundada em subsídios cruzados, gradualmente acarretou falta de incentivos e perda de eficiência operacional.

Diz Oliva Jr.: Como o desenho institucional assegurava a remuneração plena de investimentos, algumas empresas desenvolveram projetos de racionalidade econômica questionável, acelerando o processo de deterioração do sistema.

Tolmasquim $^{69}$ comenta que o cenário vivido na década de 70 é reflexo de um contexto em transformação, que encontra sua origem em período no qual a exploração da indústria elétrica se dava, no Brasil, por empresas privadas estrangeiras, situação que perdurou até meados dos anos 40, quando, já estabelecido o Código de Águas (de 1934),

\footnotetext{
${ }^{68}$ OLIVA JÚNIOR, José Roberto. Estruturas societárias e contratuais em project finance com foco em empreendimentos de geração de energia elétrica no Brasil. São Paulo, 2011. Monografia (Especialização em Direito Societário e Especialização em Direito do Mercado Financeiro e de Capitais - LLM Master of Laws) - Instituto de Ensino e Pesquisa (Insper), São Paulo, 2011. 126 p.

${ }^{69}$ TOLMASQUIM, Mauricio M. Novo modelo do setor elétrico brasileiro. Rio de Janeiro: Ed. Synergia, 2011.
} 
passou a União a centralizar as outorgas, iniciando seu domínio regulatório sobre o tema.

Com a dissociação entre geração e distribuição de energia, continua o renomado autor, assumiu a União a tarefa de construção e grandes usinas, respondendo ainda pela transmissão de energia, ficando a distribuição afeta a Estados. Nesse novo estado de coisas, em que a União coordena e executa a implantação de novos empreendimentos de geração de energia, a fundação do Banco Nacional de Desenvolvimento Econômico e Social BNDES, ao qual coube a gestão do Fundo Federal de Eletrificação - FEE, e do Imposto Único de Energia Elétrica, a oferta de energia no Brasil teve forte expansão.

Veio então a criação da Eletrobrás, e a adoção de um empréstimo compulsório (1964), consolidando-se o domínio do Estado na expansão e oferta de energia no setor elétrico.

Tolmasquin destaca então o ponto para o qual Oliva Jr. chamou a atenção, no que toca ao efeito perverso da política tarifária adotada a partir dos anos 70 , acrescentando que o fator que levou à ineficiência do sistema tem natureza política:

No modelo estatal, portanto, os recursos do Imposto Único, do empréstimo compulsório e da receita garantida constituíram uma sólida base financeira para a expansão do sistema elétrico. Esse modelo funcionou bem até o fim da década de 1970, quando a União passou a usar as tarifas das empresas do setor elétrico como instrumento de política monetária, a fim de conter a inflação.

O uso de tributos como fonte de financiamento de uma política pública expansionista, bem se vê, teve sucesso estancado pelo desvio do uso das tarifas de energia. Na década de 1980, mergulhado na crise econômica, o Estado brasileiro já não era capaz de investir, financiar o desenvolvimento do setor elétrico e expandir a oferta de energia. A crise econômica geraria, já se podia prever ali, uma crise de oferta de energia.

Paralelamente à dificuldade de ordem econômica que se vivia, a nova forma de abordar o papel do Estado no setor de energia, vendo-o como agente regulador, e não mais agente ativo direto, que se desenvolvia em países desenvolvidos, impulsionou a revisão de nosso modelo, evento que teve lugar já na década de 1990.

A revisão do modelo passaria, necessariamente, por duas frentes: a uma, a reorganização dos tributos incidentes sobre o setor, já que, alterando-se o papel do Estado, 
já não seria necessário - ou mesmo viável - manter um sistema de financiamento que visava a equacionar desequilíbrios e garantir remuneração ao setor. Em ambiente de mercado, não faria senso o Estado onerar os cidadãos para garantir a remuneração do prestador de serviço - no mais das vezes privado - que opera por concessão.

De outro lado, a mudança do papel do Estado implicaria o fim da preponderância do Estado no desenvolvimento das atividades de geração, transmissão e distribuição de energia, de sorte que um processo de desestatização seria inevitável.

A Lei $n^{\circ}$. 8.631, de 4.3.1993 (conhecida como Lei Eliseu Rezende), extinguiu o regime de remuneração garantida e realizou o encontro de contas do setor, que envolveu injeção de capital de fundos federais no Setor Elétrico Brasileiro - SEB, para tentar restabelecer o equilíbrio econômico-financeiro das empresas. Foi o primeiro passo para a reforma do setor, ensina Oliva Jr. De sua parte, Tolmasquim ${ }^{70}$ resume os pontos centrais da lei, destacando que ainda não se modificou, ali, o modelo de organização vigente:

- Extingue a equalização tarifária e institui o serviço pelo custo da própria concessionária;

- Encerra a deficitária Conta de Resultados a Compensar (CRC), com recursos do Tesouro;

- Torna obrigatórios os contratos de suprimento entre geradores e distribuidores.

A mudança de paradigma aqui é interessante: os recursos captados até então diretamente para financiamento do setor, na modalidade de um imposto (o Imposto Único), deixam de servir como instrumento da política de energia, estancando-se uma ferida que, deficitária, tendia a invariavelmente trilhar o círculo vicioso de aumento da tarifa, para financiamento do déficit, e aumento da indisponibilidade de recursos para investir. Lança-se mão de recursos do Tesouro, para estancar a sangria, e se passa a pensar no novo modelo.

Além de se ter a necessidade de saída do Estado da condição de principal agente ativo no mercado, dada a mudança de perfil proposta, para implementação de um novo modelo, verificou-se ainda falta de recursos para investir na expansão da oferta de energia, tema sempre em pauta em nosso cenário.

\footnotetext{
${ }^{70}$ TOLMASQUIM, Mauricio M. op. cit.
} 
A mudança do modelo era inevitável. A Lei Geral de Concessões (Lei nº. 8.987, de 13.2.1995) trouxe as regras para a concessão de serviços públicos e de obras públicas e permissões de serviços públicos, condicionando-os à formalização dos contratos correspondentes entre Poder Concedente e Concessionário, estabelecendo como política a contratação do serviço pelo preço (e não mais pelo custo, como era no regime anterior).

Concomitantemente à Lei de Concessões veio a Medida Provisória 890/95, convertida depois na Lei $\mathrm{n}^{\circ}$. 9.074, de 7.7.1995, por meio da qual se introduziu no sistema as figuras do Produtor Independente de Energia - PIE e do consumidor livre.

A desregulamentação era inevitável, e o Plano Diretor de Reforma do Aparelho do Estado - PDRAE, estabelecido em 1995, abriu espaço para a criação, em 1996, da Lei nº. 9.427, de 26.12.1996, que Instituiu a Agência Nacional de Energia Elétrica - ANEEL, disciplinou o regime das concessões de serviços públicos de energia elétrica.

O novo ambiente demandava a desestatização proposta. Incentivado pelo Programa de Estímulo às Privatizações Estaduais (PEPE), que disponibilizava antecipação de recursos pelo BNDES aos Estados, deu-se a privatização das distribuidoras estaduais. A iniciativa de realizar a desestatização do segmento de distribuição de energia foi vitoriosa: $85 \%$ da energia distribuída passou a se realizar por concessionárias.

O processo não poderia parar, e era necessário criar-se o ambiente para a desestatização do segmento de geração de energia. O consórcio Coopers \& Lybrand, que havia sido contratado para definir um novo modelo para o setor elétrico, apresentou proposta que trazia como elementos (i) livre comercialização de energia elétrica no Sistema Interligado Nacional (preço determinando as relações); (ii) criação do Mercado Atacadista de Energia - MAE para realizar a operacionalização do mercado de compra e venda livre de energia; (iii) desverticalização estrutural (geração e transmissão com ativos desvinculados) e operacional (venda de energia e contratação de transmissão independentes); e (iv) criação do Operador Nacional do Sistema - ONS.

A desestatização dos segmentos de geração e transmissão, realizada tão logo se estruturou o novo modelo, não trouxe os resultados esperados. Cerca de $15 \%$ da geração no Brasil é hoje de origem privada.

A crise econômica de 2001 refreou o processo de desestatização, e o racionamento imposto afastou investimentos. 
O Governo Lula, empossado em 2002, propôs nova revisão do modelo, por meio das MPs 144 e 145, de dezembro de 2003, que foram depois convertidas nas Leis $\mathrm{n}^{\circ}$. 10.847, de 15.3.2004, por meio da qual se criou a Empresa de Pesquisa Energética - EPE, e $\mathrm{n}^{\circ}$. 10.848 (regulamentada pelo Decreto Presidencial $n^{\circ}$. 5.163), igualmente de 15.3.2004, por meio da qual se dispôs sobe a comercialização de energia elétrica.

Passaram a valer então novas regras de comercialização de energia, o processo de outorga de concessões e de autorização de geração de energia elétrica que formam a espinha dorsal dos novos arranjos, consolidando assim o chamado novo modelo setorial. $\mathrm{O}$ novo modelo, cuja principal característica é um elaborado sistema de leilões de energia, tinha como objetivos principais: assegurar a expansão da oferta, garantir a modicidade tarifária ao consumidor final, além de manter um marco regulatório estável.

Comparando-se os três modelos, o que se vê é uma migração de um contexto de ação direta e interventora, condutora do mercado, pelo Estado, para um ambiente de livre mercado. Do Estado condutor e agente ativo, passa-se à figura do Estado regulador. O quadro abaixo exprime as diferenças entre os três modelos examinados:

\begin{tabular}{|l|l|l|l|}
\hline Critério & $\begin{array}{l}\text { Modelo Antigo } \\
\text { (até 1995) }\end{array}$ & $\begin{array}{l}\text { Modelo de Livre Mercado } \\
\mathbf{( 1 9 9 5} \text { a 2003) }\end{array}$ & Novo Modelo (2004) \\
\hline $\begin{array}{l}\text { Forma de } \\
\text { financiamento }\end{array}$ & $\begin{array}{l}\text { Financiamento } \\
\text { através de recursos } \\
\text { públicos }\end{array}$ & $\begin{array}{l}\text { Financiamento através de } \\
\text { recursos públicos e } \\
\text { privados }\end{array}$ & $\begin{array}{l}\text { Financiamento através de } \\
\text { recursos públicos e privados }\end{array}$ \\
\hline $\begin{array}{l}\text { Estruturação } \\
\text { das empresas }\end{array}$ & $\begin{array}{l}\text { Empresas } \\
\text { verticalizadas }\end{array}$ & $\begin{array}{l}\text { Empresas divididas por } \\
\text { atividade: geração, } \\
\text { transmissão, distribuição e } \\
\text { comercialização }\end{array}$ & $\begin{array}{l}\text { - Empresas divididas por } \\
\text { atividade: geração, } \\
\text { transmissão, distribuição, } \\
\text { comercialização, } \\
\text { importação e exportação. }\end{array}$ \\
\hline $\begin{array}{l}\text { Perfil das } \\
\text { empresas }\end{array}$ & $\begin{array}{l}\text { Empresas } \\
\text { predominantement } \\
\text { e estatais }\end{array}$ & $\begin{array}{l}\text { Abertura e ênfase na } \\
\text { privatização das empresas }\end{array}$ & $\begin{array}{l}\text { Convivência entre empresas } \\
\text { estatais e privadas }\end{array}$ \\
\hline Competição & $\begin{array}{l}\text { Monopólios - } \\
\text { competição } \\
\text { inexistente }\end{array}$ & $\begin{array}{l}\text { Competição na geração e } \\
\text { comercialização }\end{array}$ & $\begin{array}{l}\text { Competição na geração e } \\
\text { comercialização }\end{array}$ \\
\hline $\begin{array}{l}\text { Espécies de } \\
\text { consumidores }\end{array}$ & $\begin{array}{l}\text { Consumidores } \\
\text { cativos }\end{array}$ & $\begin{array}{l}\text { Consumidores Livres e } \\
\text { Cativos }\end{array}$ & $\begin{array}{l}\text { Consumidores Livres e } \\
\text { Cativos }\end{array}$ \\
\hline $\begin{array}{l}\text { Forma de } \\
\text { contratação }\end{array}$ & $\begin{array}{l}\text { Tarifas reguladas } \\
\text { em todos os } \\
\text { segmentos }\end{array}$ & $\begin{array}{l}\text { Preços livremente } \\
\text { negociados na geração e } \\
\text { comercialização }\end{array}$ & $\begin{array}{l}\text { No ambiente livre: Preços } \\
\text { livremente negociados na } \\
\text { geração e comercialização. No } \\
\text { ambiente regulado: leilão e } \\
\text { licitação pela menor tarifa }\end{array}$ \\
\hline
\end{tabular}




\begin{tabular}{|l|l|l|l|}
\hline $\begin{array}{l}\text { Controle do } \\
\text { mercado }\end{array}$ & Mercado regulado & Mercado Livre & $\begin{array}{l}\text { Convivência entre Mercados } \\
\text { Livre e Regulado }\end{array}$ \\
\hline Planejamento & $\begin{array}{l}\text { Planejamento } \\
\text { determinativo - } \\
\text { Grupo } \\
\text { Coordenador do } \\
\text { Planejamento dos } \\
\text { Sistemas Elétricos } \\
\text { (GCPS) }\end{array}$ & $\begin{array}{l}\text { Planejamento Indicativo } \\
\text { pelo Conselho Nacional de } \\
\text { Política Energética (CNPE) }\end{array}$ & $\begin{array}{l}\text { Planejamento pela Empresa de } \\
\text { Pesquisa Energética (EPE) }\end{array}$ \\
\hline $\begin{array}{l}\text { Controle de } \\
\text { contratação }\end{array}$ & $\begin{array}{l}\text { Contratação: } \\
100 \% \text { do Mercado }\end{array}$ & $\begin{array}{l}\text { Contratação: 85\% do } \\
\text { mercado (até 08/2003) e } \\
95 \% \text { mercado (até 12/2004) }\end{array}$ & $\begin{array}{l}\text { Contratação: 100\% do } \\
\text { mercado + reserva }\end{array}$ \\
\hline $\begin{array}{l}\text { Mecanismo } \\
\text { de } \\
\text { equalização }\end{array}$ & $\begin{array}{l}\text { Sobras/déficits do } \\
\text { balanço energético } \\
\text { rateados entre } \\
\text { compradores }\end{array}$ & $\begin{array}{l}\text { Sobras/déficits do balanço } \\
\text { energético liquidados no } \\
\text { MAE }\end{array}$ & $\begin{array}{l}\text { Sobras/déficits do balanço } \\
\text { energético liquidados na } \\
\text { CCEE. Mecanismo de } \\
\text { Compensação de Sobras e } \\
\text { Déficits (MCSD) para as } \\
\text { distribuidoras }\end{array}$ \\
\hline
\end{tabular}

Adaptado do site Câmara de Comercialização de Energia Elétrica.

Disponível em: <www.ccee.org.br>.

Importante verificar que, no que toca à forma de remuneração, adota-se no novo modelo o sistema híbrido de preço (para setor privado) e tarifa pela menor oferta (no setor público, para as concessões). Vale dizer, o fator que orienta o mercado é o preço da energia colocada à disposição do sistema.

Este fator é fundamental para o exercício que aqui se propõe, porque indica que a variável determinante do mercado, preço/tarifa, sobrepõe-se à variável ambiental, que fica restrita ao conteúdo do atendimento à "lei”, vale dizer, ao cumprimento do sistema de comando e controle: licenciada a atividade, estabelece-se um patamar de igualdade, sob o qual o melhor - ou pior - trato da questão ambiental deixa de ser diferencial, podendo ser elemento de perda de competitividade, já que uma melhor estrutura de controle ambiental, acima daquilo posto em lei, pode ser fator de ampliação de custos de energia gerada, com perda, portanto, de competitividade nos leilões. Voltaremos a isso mais além neste trabalho. 


\section{(viii) o Plano Decenal de Expansão de Energia}

O planejamento para o setor é realizado pela EPE, e materializado pelos planos decenais de expansão. Segundo o último Plano Decenal de Expansão de Energia (PDE 2010/2019) preparado pela EPE, a expansão em geração no período requer investimentos da ordem de R\$ 175 bilhões, sendo que parte desse investimento se refere a usinas já concedidas e autorizadas. O montante a investir em novos projetos é da ordem de R\$ 108 bilhões, dividido em diversas fontes de energia, porém com predominância em geração hídrica.

Seja pela disponibilidade de potenciais hidráulicos, seja em razão do preço/tarifa, a matriz hídrica predomina em nosso parque gerador, observando-se, nos últimos anos, avanço substancial da matriz térmica na composição de nosso parque. Vale verificar a composição do parque gerador nacional, conforme divulga a ANEEL (www.aneel.gov.br/BIG - Banco de Informações de Geração):

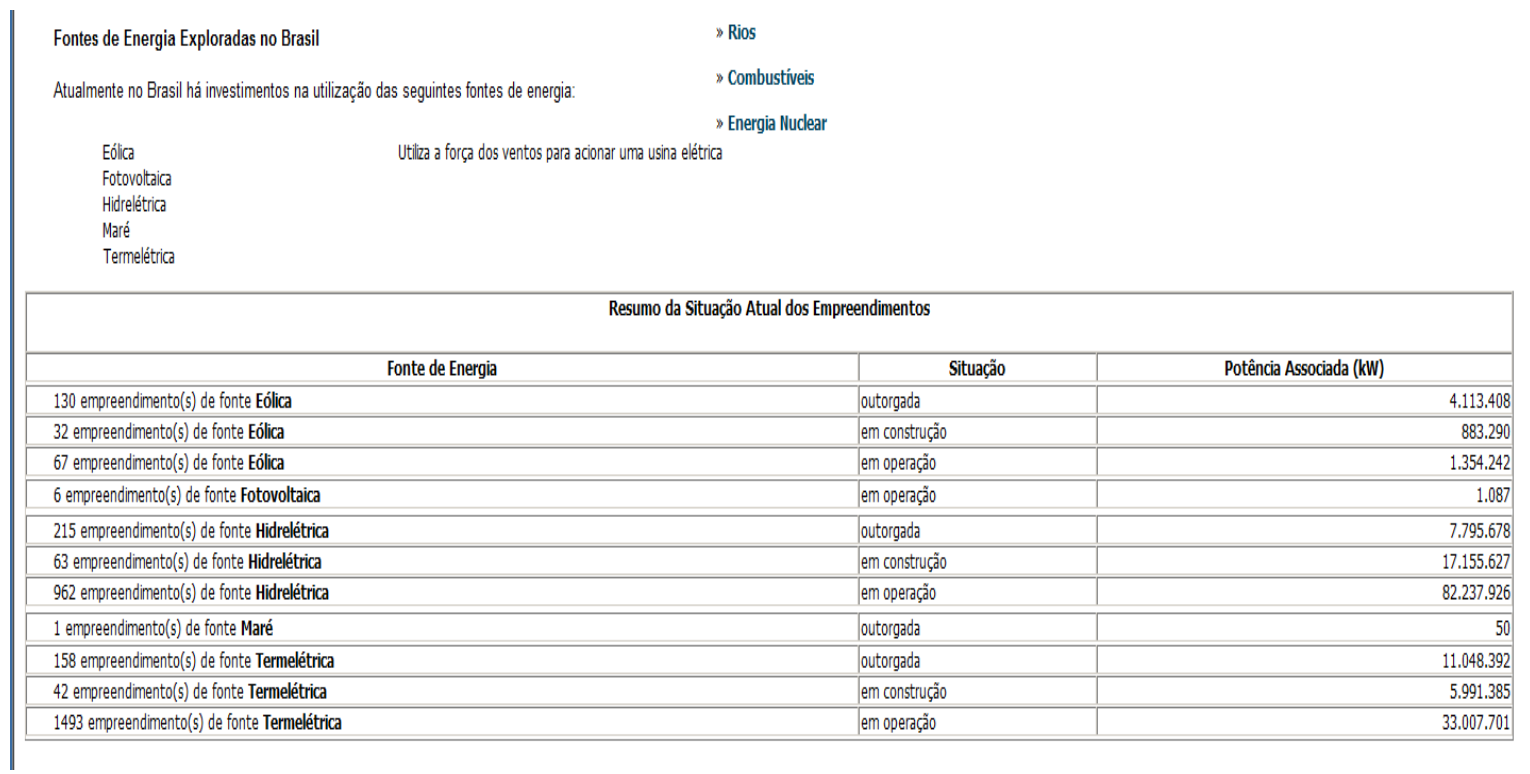

Conforme se vê do quadro, o parque gerador brasileiro, tomando-se a coluna "Situação", apresenta 82 milhões de Kw gerados pela matriz hídrica, enquanto o total em operação para a matriz térmica corresponde a 33 milhões de $\mathrm{Kw}$, demonstrando a evolução dessa matriz, em larga escala alimentada por fontes combustíveis fósseis, nos últimos 15 anos, no cômputo total de nosso parque gerador. Já no que toca às fontes fotovoltaica e 
eólica, matrizes ditas "limpas" (mais ainda do que a hídrica), os volumes de energia gerada são irrisórios, contando $1.000 \mathrm{Kw}$ para a fotovoltaica, e 1,3 milhão de Kw para a eólica.

O avanço da matriz eólica, que deve ser recebido com aplausos, é percebido no fato de estarem já outorgados, mas ainda não instalados, 4,1 milhões de Kw. Esse número, no entanto, é suplantado em quase 3 vezes pelo volume outorgado para a fonte térmica, que chega a 11 milhões de Kw.

Do exame desses e dos demais elementos postos no quadro, o que se vê é que nosso parque gerador apresenta, no quadro atual, uma tendência de ampliação da participação percentual das fontes ditas "sujas" de energia.

Exame de valores percentuais da participação de cada fonte energética em nosso parque gerador revela o gráfico abaixo:

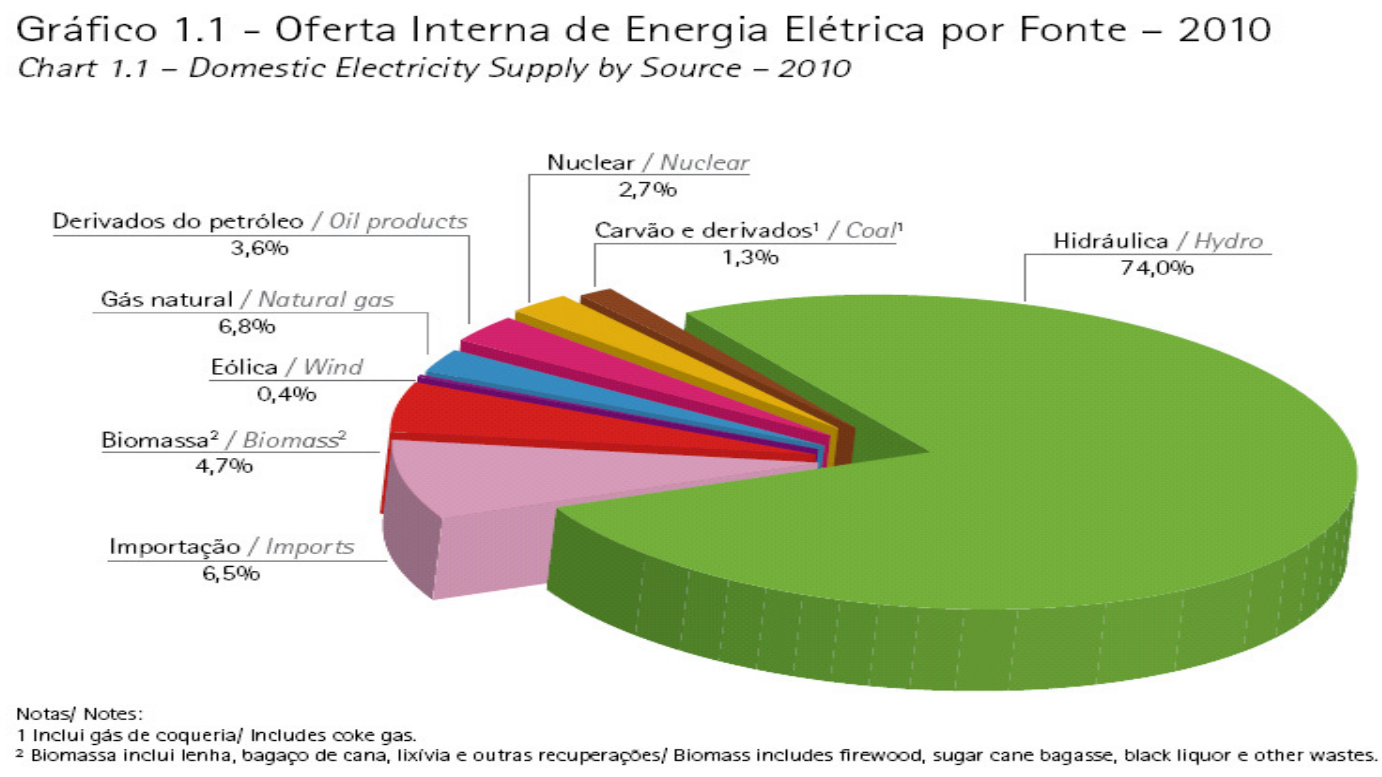

A forte participação da matriz hídrica em nosso parque gerador ainda garante uma matriz total que se pode chamar de "limpa", abordado o tema a partir da perspectiva do uso de combustíveis fósseis e matrizes não renováveis de geração de energia. Não se pode, no entanto, desconsiderar o avanço das fontes ditas "sujas", representadas pela matriz térmica.

Analisado o avanço previsto para a oferta de energia instalada, no período de 20052030, verifica-se a queda substancial da participação da matriz hídrica em nosso parque gerador (de 91\% para 78\%), ao mesmo tempo em que as matrizes não-renováveis ganham espaço. Não obstante a consolidação da cana-de-açúcar (biomassa) como uma de nossas 
fontes relevantes de energia (cerce da $15 \%$ do aumento da oferta de energia), o aumento potencial de nossas emissões de GEE, em números absolutos, pelo aumento do parque gerador fundado em matrizes não-renováveis (praticamente $23.000 \mathrm{MW}$ a serem acrescidos ao sistema, entre 2005 e 2030, em ampliação da oferta em valores próximos a 140\% sobre a de 2005), é algo que não se pode desconsiderar. Em termos nominais, a ampliação da oferta de energia de origem hídrica é muito próxima à ampliação da oferta pelas matrizes não-renováveis (19.100 MW para a matriz hídrica, ante 22.945 MW de ordem não-renovável). Em termos percentuais, no entanto, a oferta pela matriz hídrica se ampliará em pouco menos de $30 \%$, enquanto a oferta de energia de origem não-renovável será ampliada nos já referidos cerca de $140 \%$.

Graças à inserção das matrizes renováveis na composição de nosso parque gerador, chegaremos a 2030 com queda na participação percentual total das fontes não-renováveis, considerado o todo do parque gerador (decréscimo de cerca de 19\% para algo em torno de 12,5\%). Ainda assim, repita-se, não se pode deixar o número aparentemente positivo mascarar o fato, insofismável, de que o acréscimo de 22.945 MW em nosso parque gerador, por fontes não-renováveis, gera um potencial aumento de nossas emissões de GEE, no que toca à geração de energia, substancial.

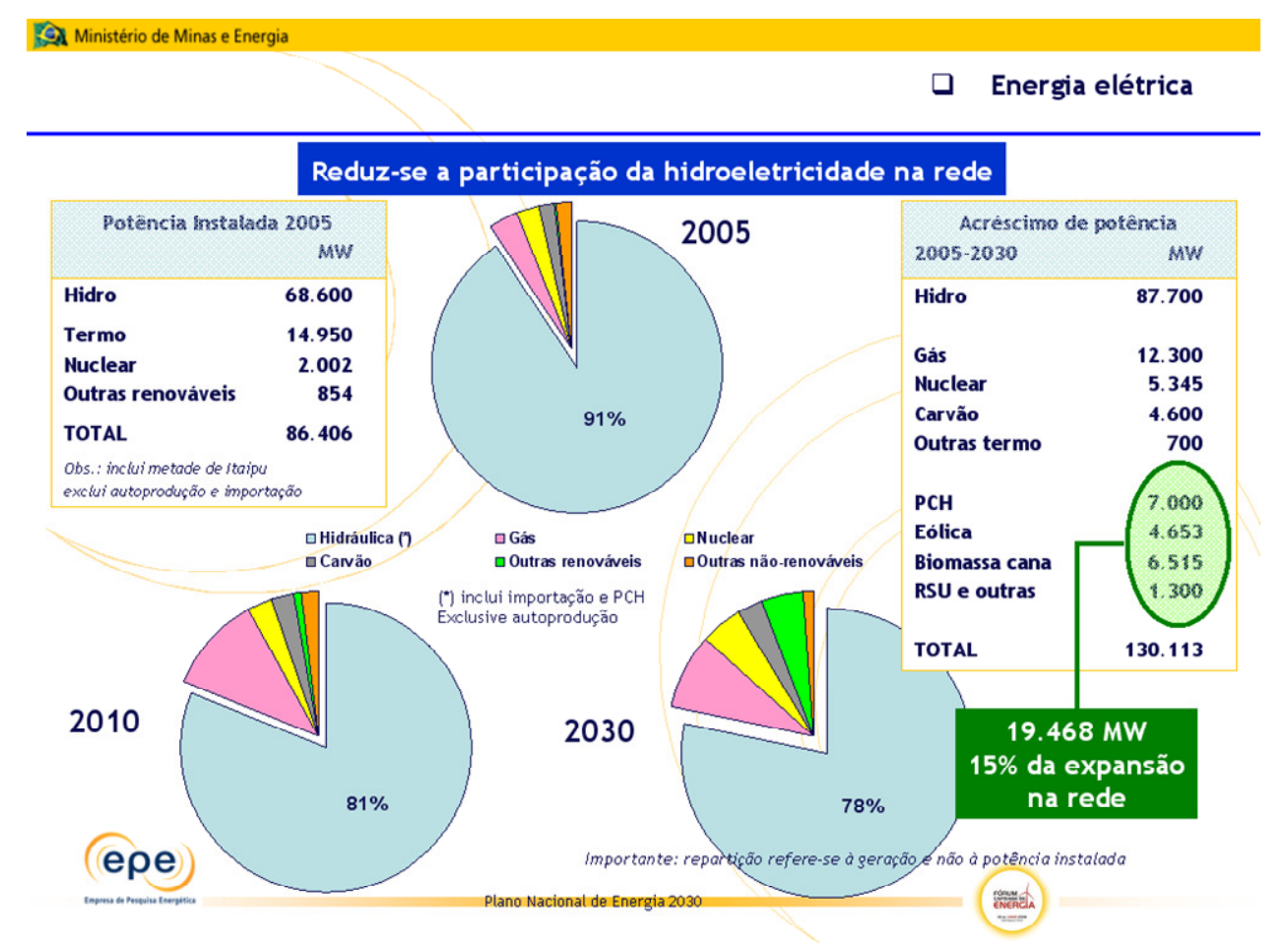


O ponto a indagar, aqui, é: seria este o desenvolvimento do parque gerador elétrico brasileiro desejado pela sociedade, consideradas as políticas públicas de energia e ambientais? Tomadas as políticas de caráter ambiental transversais à política energética brasileira, é este o resultado que se quer ver para a expansão de nosso parque gerador?

\section{(ix) o modelo atual, sua estrutura e o efeito para as políticas públicas transversais}

Para que se possa perquirir acerca da resposta adequada à pergunta formulada acima, necessário retomar ponto colocado acima, no quadro referente aos três modelos do setor de energia, atentando-se para o específico ponto da forma de contratação do fornecimento de energia. No modelo atual, ali se destaca, a contratação de energia se dá, no ambiente livre, pela definição de preço, enquanto, no mercado regulado, a contratação de energia se dá pelo modelo licitatório, contratando-se a menor tarifa.

Assim, ainda que a política energética nacional (Lei nº 9.478, de 6.8.1997, citada acima neste tópico) estabeleça entre seus objetivos tópicos como a proteção do meio ambiente, o fato é que, na implementação de seus mecanismos, o vetor central de definição para a contratação de energia será sempre o fator preço/tarifa. Os elementos vários elencados pelo artigo $1^{\circ}$ da Lei, que refletem, entre outros, a consideração das variáveis ambiental, social, e outras, têm sua inserção no âmbito do processo de formação da contratação de energia em fases prévias à contratação propriamente dita, o que acarreta dois desvios de ordem estrutural: a uma, variáveis fundamentais à implementação da política energética, porque nesta, mesmo definidas como a ela transversais, ficam relegadas a segundo plano, operando meramente como "condição" para a habilitação à participação em leilões de energia. A duas, o diferencial para a contratação de energia fica restrito ao fator preço/tarifa.

Tome-se, no que toca ao primeiro desvio afirmado, a questão do licenciamento ambiental como variável transversal à política energética (a regularidade ambiental exprimida pelo licenciamento ambiental, o que não se confunde, naturalmente, com estado de sustentabilidade do empreendimento submetido ao licenciamento ambiental): para que se habilite a participar de leilão voltado à contratação de energia nova, o interessado deve comprovar que o empreendimento a ser implementado goza de, no mínimo, Licença Prévia expedida pelo órgão ambiental competente. 
A Licença Prévia é documento pelo qual se atesta a viabilidade socioambiental de um determinado projeto. Assim, emitida esta pela autoridade ambiental competente, presume-se que o projeto atenda às condições mínimas para sua aprovação. Vale dizer, tratamos aqui do atendimento estrito aos regramentos legais que se aplicam ao licenciamento ambiental e, atendida a lei (aqui em sentido lato), atesta-se tal condição pela emissão da Licença Prévia.

Ocorre que, considerada a transversalidade da variável ambiental - e, em seu bojo, como queremos considerar, a climática - à variável energética, parece-nos pouco o mecanismo adotado, que atua sobre os empreendimentos geradores de energia de forma pontual, localizada, cuidando de seu atendimento à lei, mas não o inserindo, por meio de exercício comparatório, no âmbito do rol das atividades voltadas à geração de energia.

E o resultado, estamos a ver pela evolução de nosso parque gerador, é de ampliação da participação de fonte dita "suja" em nosso parque gerador, o que impacta a habilidade do Estado de fazer cumprir metas e objetivos de políticas públicas outras, como a Política Nacional sobre Mudança do Clima.

\section{- considerações finais do ponto}

A postura de liderança adotada pelo Brasil, no âmbito dos debates internacionais acerca da necessidade de redução das emissões de GEE, nos obriga a posturas coerentes, no plano interno. Nossa peculiar situação, no tocante às fontes principais de nossas emissões de GEE, impõem que a implementação dos instrumentos voltados à consecução dos objetivos da Política Nacional sobre Mudança do Clima tenha convergência direta com nossas políticas florestal e energética. O exame dessas políticas públicas, e dos instrumentos por elas criados, demonstra não se ter a variável climática em consideração efetiva quando de sua formulação. A integração entre essas políticas e a Política Nacional sobre Mudança do Clima é portanto fundamental ao alcance dos objetivos dos três temas distintos (conservação florestal sustentável, geração de energia nas melhores condições de preço e atendendo-se ao preceito da sustentabilidade, e redução de nossas emissões de GEE, alcançando-se as metas postas). 


\section{A IMPLEMENTAÇÃO DO ARTIGO 6º, VI, DA LEI No. 12.187/2009: A INTERVENÇÃO QUALITATIVA DO ESTADO SOBRE A ORDEM ECONÔMICA, OS MECANISMOS TRIBUTÁRIOS DISPONÍVEIS, E O ENTENDIMENTO QUANTO AO CAMINHO A TRILHAR}

\section{(1) o exame já feito e as constatações e premissas a adotar para este ponto do trabalho}

Do quanto até aqui expendido, extrai-se pontos que servem de premissas para a abordagem do tópico próximo, referente à forma de implementação das medidas elencadas pela Política Nacional sobre Mudança do Clima como aptas à busca do atendimento às metas estabelecidas de redução de nossas emissões de GEE.

O primeiro e fundamental desses pontos é que, examinado o sistema de controle de atividades de risco ambiental vigente, implementado a partir do estabelecimento da Política Nacional de Meio Ambiente (a Lei $n^{\circ}$. 6.938/81), observa-se a necessidade de se adotar medidas para complementá-lo, por meio das quais se utilize meios alternativos ao comando e controle como vetor de conduta do Estado; vê-se ainda que o princípio informador da criação de novos mecanismos legais deve ser o da busca da sustentabilidade, considerandose a necessidade de regulação do acesso aos recursos naturais sob a premissa de sua natureza intergeracional; para se materializar essas regras, sob esse novo signo, o da sustentabilidade, deve-se lançar mão dos princípios do usuário-pagador (que precifica o acesso, e não a degradação do meio ambiente e resposta a essa degradação) e do protetorrecebedor (em que igualmente se atribui um valor econômico à conduta humana diante desses princípios e paradigmas da relação homem $\mathrm{X}$ meio ambiente, mas aqui sob a vertente positiva, ou seja, busca-se a atribuição de valor econômico ao bem agora protegido, e não mais degradado).

Nesse contexto, instrumentos para materialização da presença do Estado nas relações homem $\mathrm{X}$ meio ambiente assumem papel de incentivo e estímulo, e deixam de caracterizar o Estado interventor puro, de regulação pela imposição de regras de conduta, 
para dar lugar ao Estado indutor, que intervém na ordem econômica, não mais apenas para deprimir e controlar o risco das atividades, mas para estimular o desenvolvimento de atividades de menor risco. Assim pontua Alejandro Altamirano, citado por José Marcos Domingues $^{71}$ :

É melhor incentivar que penalizar, estimular o investimento no controle da contaminação do que sancionar com penalidades cuja existência tem por efeito asfixiar a atividade industrial, quando não criam elas um clima de incerteza sobre as consequências de sua execução.

O Estado indutor surge, naturalmente, diante de uma lacuna, que é, nos dizeres de Fábio Nusdeo $^{72}$, a lacuna proporcionada pela ineficiência do mercado em identificar, tratar e internalizar as externalidades negativas da produção econômica. A intervenção do Estado, qualitativa, não implica eliminar o sistema econômico de mercado, mas tão somente vem para induzir ou refrear a atividade econômica, buscando com isso otimizar a internalização de custos e equilibrar a relação entre produção econômica e proteção ambiental.

Por outras palavras, o que se busca é sistema em que o risco, ao invés de constituir uma externalidade que pode se materializar, trazendo a necessidade de resposta pelo Estado, em prol do meio ambiente, passa a constituir variável a ser internalizada e, portanto, a ser evitada pelo empreendedor, reduzindo-se assim, proporcionalmente, a incidência de materialização desse risco (ocasiões em que ainda deve haver, naturalmente, a resposta pelo Estado). Importa destacar, desde logo, que nesses próximos tópicos não faremos distinção entre impactos e danos ao meio ambiente, como origem da intervenção do Estado na atividade de risco.

Ainda que a distinção seja fundamental para a identificação de suas consequências no plano jurídico, o fato é que, no âmbito deste trabalho, o que se pretende identificar e propor é a adoção de mecanismos que levem à minimização da ocorrência de externalidades negativas decorrentes da atividade produtiva ligada aos setores da economia eleitos para exame, e o termo externalidades pode ser tomado como de amplitude bastante para abranger impactos e danos.

\footnotetext{
${ }^{71}$ DOMINGUES, José Marcos. Direito tributário e meio ambiente. 3. ed. Rio de Janeiro: Forense, 2007. p. 54-55.

${ }^{72}$ NUSDEO, Fábio. op. cit., p. 143.
} 
Disso é que nos ocuparemos nos próximos itens: buscar identificar, no que toca aos setores de florestas e energia, os mecanismos adequados a fazer frente a essa necessidade.

\section{(2) A intervenção qualitativa do Estado sobre a ordem econômica - a base teórica para essa abordagem, no âmbito da questão ambiental - a inserção da questão ambiental no campo econômico}

Na parte inicial deste trabalho mencionamos que, no ensinamento de Canotilho, exerce o Estado três funções de ordens distintas. A primeira dessas funções consistente em manutenção de uma ordem-quadro para o exercício da liberdade política e económica, não cabe aqui abordar, posto não tocar ao objeto do que se propõe e, se demandasse aqui exame, estaríamos ainda em estágio pré-democracia.

O foco de exame, considerada a divisão proposta por Canotilho, reside na função de segunda ordem, que o festejado professor diz implementar-se por meio de uma política de 'intervenção' $e$ 'estímulo' com o fim de criar instrumentos de 'integração' necessários à organização capitalista da economia; e na função de terceira ordem, qualificada pelo professor como a função de realizar intervenções qualitativas na ordem económica existente.

Para que se possa realizar esse exame, no entanto, impõe-se que se dedique algumas linhas, antes, a identificar dois pontos: a uma, o papel do Estado diante da perspectiva que adotamos para o exame da questão ambiental. A duas, a questão ambiental no plano da ordem econômica.

O fundamento para que se afirme que ao Estado, no que toca à questão aqui em exame, cabe agir nos termos das posturas indicadas por Canotilho, encontra-se a nosso ver na nossa Constituição, dado que se pode dela extrair: (i) o conceito da sustentabilidade como vetor de orientação para as políticas públicas de meio ambiente; (ii) a necessidade de atendimento aos objetivos firmados na Convenção-Quadro sobre Mudança do Clima, por decorrência de nossa estrutura; e (iii) a vocação de intervenção qualitativa na ordem econômica.

Ora, já se esclareceu acima que, diante do quanto posto no artigo 225 , caput, da nossa Constituição Federal, deve nosso sistema orientar-se pela garantia da preservação dos recursos naturais para as presentes e futuras gerações. $\mathrm{O}$ caráter intergeracional de nosso 
direito ambiental já indica a necessidade de observância de uma postura de

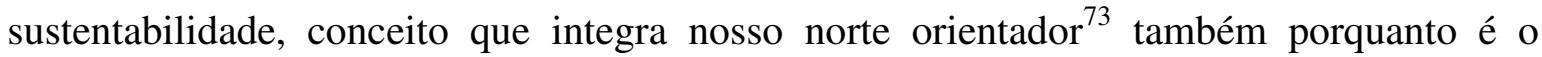
Brasil signatário da Declaração do Rio de Janeiro sobre Meio Ambiente e Desenvolvimento (dos 27 princípios ali declarados, $12^{74}$ trazem expressa menção ao desenvolvimento sustentável).

No que concerne, de outro lado, aos princípios e objetivos da Convenção-Quadro sobre Mudança do Clima, já se demonstrou, igualmente, que sua internalização em nosso sistema nos obriga a tal tarefa.

Por fim, no que toca à vocação para a intervenção qualitativa na ordem econômica, notadamente no que diz respeito à questão ambiental, o fundamento principal e direto encontra-se inserto no inciso VI do artigo 170 do texto da Constituição Federal, conforme redação conferida pela Emenda Constitucional no . 42/2003, já transcrito acima neste texto, mas que vale novamente transcrever:

VI - defesa do meio ambiente, inclusive mediante tratamento diferenciado conforme o impacto ambiental dos produtos e serviços e de seus processos de elaboração e prestação;

Ora, o texto é claro: faculta ao legislador infraconstitucional (ou melhor, impõe) criar mecanismos pelos quais se dê tratamento diferenciado a determinados produtos e serviços, observados os seus meios de prestação ou produção, visando através de tal conduta garantir a defesa do meio ambiente, entendida esta como parte do todo a que se refere o artigo 225 da Constituição Federal, quando trata da defesa (e preservação) do meio ambiente para as presentes e futuras gerações.

Por outros termos, pode-se concluir que o legislador constitucional, ao trazer a redação atual ao inciso VI do artigo 170 da Constituição Federal, trouxe à realidade de nosso sistema, no que toca à matéria ambiental, de forma expressa, a função de realização da intervenção qualitativa na ordem econômica, a que se refere Canotilho, tendo como objetivo finalístico, entendida a expressão "defesa do meio ambiente" na sua adequada dimensão, o alcance da preservação dos recursos naturais para as presentes e futuras

\footnotetext{
${ }^{73}$ Aqui, interessante notar que o termo usado "norte orientador" é propositadamente empregado, porquanto, tratando-se de Declaração, opera-se no campo da soft Law, não se tendo, portanto, um instrumento mandatório, mas sim um princípio orientador.

${ }^{74}$ São os princípios de números $1,3,4,7,8,9,12,20,21,22,24$ e 27.
} 
gerações, em clara busca da sustentabilidade.

Sob esse paradigma, da sustentabilidade, que se respalda no caráter intergeracional de nosso sistema de defesa e preservação ambiental, assume o papel de intervenção qualitativa do Estado especial perfil, conforme destaca Fernando Magalhães Modé ${ }^{75}$, citando John Proops:

John Proops em artigo assinado juntamente com outros três especialistas em questões atinentes à economia ecológica ressalta esse papel fundamental do Estado:

"Com relação aos processos políticos que seriam necessários à sustentabilidade, nossa opinião é que o papel do Estado é 'liderar' o mercado (com todas as suas imperfeições), em vez de 'segui-lo', como ocorre atualmente. Enquanto o mercado certamente será o nexo de interação econômica, o marco dentro do qual ele atua precisará ser estabelecido mediante consenso, pelo Estado. Embora, mesmo nos sistemas democráticos, o Estado seja suscetível aos interesses de grupos poderosos, acreditamos que só o Estado, enquanto instituição, pode oferecer potencialmente a escala temporal necessária à sustentabilidade, além de possuir a autoridade e os meios potenciais para atuar como um agente de equilíbrio em face dos poderosos grupos de interesse.

(...) só o Estado como instituição pode, potencialmente, prover a escala temporal de longo prazo necessária para se solucionarem os problemas ambientais. Nos últimos anos, aprendemos que o mercado é uma instituição eficiente para resolver problemas e alocação de curto prazo. Porém, quando nos defrontamos com questões de longo prazo, os mercados fracassam. Os agentes econômicos frequentemente tomam decisões míopes, à base de comparações de custos e benefícios individuais (privados). Assim, preferem ter benefícios no presente em vez de no futuro, e custos no futuro e não no presente. Negligenciam, dessa forma, em suas decisões, o custo decorrente da degradação ambiental."

O Estado, portanto, tem papel de controle e de indução, para direcionar o mercado a uma postura de longo prazo, sustentável.

Para o exercício desse papel, deve o Estado valer-se, no exame do status quo de um determinado segmento ou situação econômico ou social, da verificação do atendimento, por aquele segmento ou situação, dos elementos que compõem a condição de busca da sustentabilidade, ou ainda dos objetivos da ordem econômica. Estando-se fora dessa condição, deve o Estado valer-se de sua prerrogativa de intervenção sobre a ordem econômica, de maneira a, buscando o "justo", assim entendido este como aquela situação

\footnotetext{
${ }^{75}$ MODÉ, Fernando Magalhães. Tributação ambiental: a função do tributo na proteção do meio ambiente. 5. reimpr. Curitiba: Juruá, 2007. p. 46-48.
} 
ou condição em que se atende aos elementos que compõem a condição de busca da sustentabilidade, e ainda dos objetivos da ordem econômica, e os objetivos da Constituição, alterar o status quo social e do mercado, redirecionando e reorientando-os.

E o justo, aqui, é invocado sob a premissa de que a ordem constitucional é o anseio de todos, ou seja, a Constituição reflete a vontade do todo da sociedade. Afinal, justa será, nas palavras de Agnes Heller e Ferenc Fehér ${ }^{76}$, aquela situação em que as normas e regras são aceitas como justas por todos os envolvidos, em resultado de um discurso de valor no qual todos têm recurso aos valores universais de liberdade e vida.

A busca pela ordem econômica que logre proporcionar existência digna, em harmonia com a busca da sustentabilidade, como função do Estado, passa a ter um elemento de constituição a mais: o justo como elemento determinante de intervenção do Estado na ordem econômica, para correção de distorções e consecução dos objetivos constitucionais.

A forma de materialização dessa intervenção qualitativa, ou seja, a materialização desse tratamento diferenciado a que se refere o dispositivo constitucional, é ponto a ser adrede esmiuçado. Afirma-se, desde logo, a necessidade de se buscar, como princípio orientador, não mais o princípio do poluidor-pagador em seu entendimento tradicional, que deu fundamento e razão (associado ao princípio da prevenção) ao sistema posto e em vigência. Demais disso, deve-se desde logo afastar a possibilidade de se operar com a ideia de criação de um sistema fundado em "taxas ambientais". Isto porque, se vinculada a proposta a se formular a essas premissas, estar-se-á diante do risco de inviabilização, nas palavras de José Casalta Nabais ${ }^{77}$, de um estado fiscal suportável. Assim pontifica o autor:

Mas, respondendo mais especificamente a essa questão, devemos adiantar que, nem em sede do financiamento geral do estado, nem em sede do específico financiamento da protecção do ambiente ou da regulação económica e social, a figura das taxas está em condições de se apresentar como suporte financeiro principal do estado nos tempos que correm.

\section{(...)}

Mas, se em geral, como acabamos de ver, está excluído um estado principalmente financiado através de taxas, será viável ao menos um

\footnotetext{
${ }^{76}$ HELLER, Agnes; FEHÉR, Ferenc. A condição política pós-moderna. 2. ed. Rio de Janeiro: Civilização Brasileira, 2002. p. 181.

${ }^{77}$ NABAIS, José Casalta. Reforma tributária num estado fiscal suportável. In: NUNES, António José; COUTINHO, Jacinto Nelson de (Orgs.). O direito e o futuro - o futuro do direito. Coimbra: Almedina, 2008. p. 257-260.
} 
estado tributário no domínio do direito do ambiente, um estado financiado através de taxas ambientais?

\section{$(\ldots)$}

Pelo que, mesmo nesse sector mais restrito do direito do ambiente, em que, pelo menos prima facie, parecia fácil socorrermo-nos da figura das taxas, chegamos à conclusão de que não é viável que o estado seja suportado maioritariamente por tributos bilaterais ou taxas, em vez de tributos unilaterais ou impostos.

Eis, pois, o desafio: encontrar uma proposta por meio da qual se realize a intervenção qualitativa do Estado na ordem econômica, para que se tenha viabilizada a busca da condição de sustentabilidade, sem que, com isso, se adote um modelo de estado fiscal que não seja “suportável”. Exploraremos essa possibilidade mais adiante.

Já no que toca à abordagem da questão no plano da ordem econômica, de pronto, destaca-se que não há prevalência entre princípios, senão na análise, pelo julgador, do caso concreto. Princípios são normas jurídicas entre os quais sempre haverá tensão, dado assim ser porque próprio do sistema jurídico. Assim, no exame do caso concreto, deverá um deles prevalecer, perdendo eficácia (e não validade), para aquele caso, naquele momento, as regras que dão aplicação prática ao princípio desprezado em benefício de outro, entre os quais se via, para o caso concreto, repita-se, tensão a ser resolvida ${ }^{78}$.

Cabe aqui trazer a lição de Heleno Tôrres ${ }^{79}$, para quem os princípios constitucionais distinguem-se entre os fundamentais e aqueles que não guardam tal condição, verificandose, no entanto, que diante de aparente conflito, relativizar-se-á essa condição hierárquica, buscando-se, sempre, o que Tôrres denomina de "preferência de otimização" de um determinado princípio em detrimento de outro, quando posta a colisão entre eles.

Faz-se esse destaque primeiro para que se diga desde já: a busca da sustentabilidade, como elemento de indução da interpretação e aplicação das normas insertas no sistema, impõe a constante contraposição entre dois princípios constitucionais explícitos, e a solução para a sempre presente tensão entre esses princípios, vista a questão econômico-ambiental sob a perspectiva da busca pela sustentabilidade, demandará soluções, pelo intérprete, sempre pontuais, diante do caso concreto.

\footnotetext{
${ }^{78}$ Os conceitos aqui adotados retiram-se de GRAU, Eros Roberto. Ensaio e discurso sobre a interpretação/aplicação do direito. 5. ed. São Paulo: Malheiros Ed., 2009. p. 46-60.

${ }^{79}$ TÔRRES, Heleno Taveira. Segurança jurídica do sistema constitucional tributário. 2011. Tese (Titular) Faculdade de Direito, Universidade de São Paulo, São Paulo, 2011. p. 828.
} 
A respeito desse estado de tensão, Gilberto Dupas ${ }^{80}$, tratando do tema, indica que duas são as tensões criadas, nas últimas décadas, pelo capitalismo global, sendo uma delas a que toca à crise ambiental decorrente do modelo econômico vigente:

Nos últimos vinte anos, o capitalismo global gerou duas tensões fundamentais, que agora convergem para um mesmo impasse cultural. De um lado, a estagnação dos níveis de miséria e pobreza - e o agravamento da concentração de renda - de muitos dos grandes países da periferia mundial que haviam sido deixados ao livre-arbítrio dos mercados e de sua lógica global, trazendo a imperiosa necessidade de retomada de seu crescimento. De outro, uma crise ambiental sem precedentes, provocada pelo próprio modelo econômico "sucateador" de produtos e "esbanjador" de energia, agora agravada pela bem-sucedida opção de China e Índia por se associarem àquela própria lógica, crescendo a taxas elevadas.

A tensão, portanto, é constante, no terreno prático e no sistema. Qualquer situação que se tome para exame, em que se tenha a produção econômica como tema de interesse, necessariamente imporá a consideração da variável ambiental como fator determinante na tomada de decisões e escolha de caminhos.

Não obstante, porque aqui se trata da busca de harmonização entre preservação e defesa do meio ambiente, de um lado, e desenvolvimento econômico, de outro, sempre sob essa perspectiva da harmonização é que dedicaremos algumas linhas a tratar dessa tensão, em tese, sem que tenhamos aqui um caso concreto a examinar e interpretar, para que possamos estabelecer uma premissa (não é o melhor termo; talvez norte) ou uma pauta de orientação para o que defenderemos, ao depois, quando examinarmos a questão das formas de intervenção do Estado na ordem econômica para indução de condutas, tomada a questão do clima, nos setores de florestas e energia.

Muito já se discutiu acerca do perfil de nosso sistema constitucional, no que toca à opção entre uma postura antropocentrista ou ecocentrista ${ }^{81}$. As opiniões se dividem.

Não obstante as opiniões pendendo para um e outro lado, cabe aqui defender interpretação própria. A nosso ver, o sistema constitucional não é sempre antropocentrista

\footnotetext{
${ }^{80}$ In: DUPAS, Gilberto (Org.). Meio ambiente e crescimento econômico: tensões estruturais, cit., p. 21-23.

${ }^{81}$ Os termos antropocentrismo e ecocentrismo parecem inadequados ao que se discute: a orientação de nosso sistema constitucional, fazendo prevalecer como norte a proteção ao homem, ou a defesa e preservação do meio ambiente. No entanto, adota-se esses termos em respeito ao fato de assim o fazer a doutrina, em geral, quando da abordagem do tema, como é o caso de MILARÉ, Edis; COIMBRA, José de Ávila Aguiar. Antropocentrismo x ecocentrismo na ciência jurídica. Revista de Direito Ambiental, São Paulo, v. 36, p. 941, out./dez. 2004. Vide também COIMBRA, José de Ávila Aguiar. $O$ outro lado do meio ambiente. São Paulo: Ed. Millenium, 2002.
} 
ou ecocentrista: ao contrário, oscila entre uma e outra postura conceitual, intensificando as tensões entre princípios de um e outro perfil. No plano geral, no entanto, queremos entender que prevalece, especialmente diante de situações de conflito, a postura antropocentrista. Não se quer com isso afirmar, no entanto, que sucumbiria a defesa e preservação ambiental diante do interesse do homem. O que se afirma, e de forma peremptória, é que tal princípio integra a formulação, em si, do direito a ser exercido sob a perspectiva do antropocentrismo.

Explico-me.

Nossa Constituição Federal, já em seu artigo $1^{\circ}$, III, fixa como um dos fundamentos de nosso Estado Democrático de Direito a dignidade da vida humana. Já se vê, aí, orientação antropocentrista. No entanto, parece livre de dúvida que somente existirá a possibilidade de vida humana digna desde que preservado o meio ambiente. Santiago Felgueras ${ }^{82}$ comunga desse entendimento, ao sustentar que a degradação ambiental pode chegar a impedir o gozo de direitos já reconhecidos (...) como o direito à vida e à saúde.

Não é diferente o que se vê no artigo 170 da Constituição: no caput se declara que a ordem econômica tem por fim assegurar existência digna a todos, em mais um claro viés de prestígio ao ser humano como destinatário do sistema. Em seguida, declara-se que, para o alcance desse estado, o de existência digna, faz-se necessário observar como princípio a defesa do meio ambiente (inciso VI).

Ora, parece claro que o sistema se estrutura de forma tal que a defesa e preservação do meio ambiente, antes e ao invés de caracterizar princípio que possa estar ou entrar em tensão com a ordem econômica, integra os requisitos de alcance, pela ordem econômica, de seus fundamentos, já que, conforme se afirmou acima, existência digna não existirá sem um meio ambiente hígido a prestar o suporte a tanto. A tensão, pois, surgirá diante do caso concreto.

Por fim, o artigo 225, caput, ao tratar do direito de todos ao meio ambiente ecologicamente equilibrado, classificando-o como bem de uso comum, reitera essa condição sob a qual o meio ambiente pode ser manipulado pelo povo, já que constitui bem público. A evolução do conceito, para a adoção do conceito de bem ambiental, relativiza essa disponibilidade de manipulação.

\footnotetext{
${ }^{82}$ FELGUERAS, Santiago. Derechos humanos y médio ambiente. Buenos Aires: Ed. Ad-Hoc, 1996. p. 17.
} 
A conclusão a que chegamos, dessa rápida análise, é que a tensão pode e deverá ocorrer quando diante de casos concretos. No entanto, no plano teórico, quando se lança olhar sobre a relação entre a defesa e preservação ambiental, diante da ordem econômica, percebe-se que, para que se atinja esta, dever-se-á passar por aquele, defendendo-o e preservando-o. Não há, pois, conflito, ou prevalência de postura antropocentrista ou ecocentrista, senão convivência sem tensão (sempre no plano teórico; no plano prático, a tensão é perene, insuperável mesmo, sempre temperando a relação entre homem e meio ambiente).

Vista essa condição, sob a qual o meio ambiente caracteriza requisito à ordem econômica adequada a assegurar a existência digna a todos que almeja, justifica-se que, para a busca do desenvolvimento de instrumentos de implementação da Política Nacional sobre Mudança do Clima, aborde-se o meio ambiente e seus elementos como sujeitos à absorção pela ordem econômica.

Isto porque, para que tenha lógica econômica a defesa e preservação do meio ambiente, far-se-á necessário atribuir-lhe - e a seus elementos diretos, derivados e externos - valoração econômica. Convém trazer doutrina de suporte a esta afirmação.

Iniciamos pelo magistério de Fábio $\mathrm{Nusdeo}^{83}$, para quem o importante é ter presente que o problema ecológico é de natureza econômica e, portanto, o seu tratamento somente se fará com êxito mediante a utilização de instrumentos conaturais ao próprio sistema econômico.

O já citado Ricardo Carneiro ${ }^{84}$ - e não é demais novamente reproduzir o texto antes transcrito - indica que, dada a condição de requisito à continuidade da atividade econômica, a preservação de recursos ambientais deverá integrar essa atividade, como condição de sua existência e regularidade.

Desse modo, de acordo com os discursos constitucional e infraconstitucional, a atividade econômica no Brasil deve conciliar-se com a necessidade de garantia de seu processo de continuidade, através da preservação dos recursos ambientais, havendo a clara indicação de que os padrões de desenvolvimento econômico juridicamente desejados são aqueles que satisfaçam aos critérios de preservação de nosso patrimônio ambiental natural. Assim, os modelos insustentáveis, que não se adéquam aos pressupostos da preservação do meio ambiente, não são considerados em nosso sistema como verdadeiros modelos de desenvolvimento.

\footnotetext{
${ }^{83}$ NUSDEO, Fábio. Curso de economia: introdução ao direito econômico. 3. ed. São Paulo: Ed. Revista dos Tribunais, 2001. p. 375.

${ }^{84}$ Vide nota 26.
} 
Américo Luís Martins da Silva ${ }^{85}$ também aborda a questão, vendo que o uso racional - sustentável - dos recursos naturais integra um modelo de produção aceitável, legítimo, reforçando o entendimento de que o meio ambiente - e sua defesa e preservação passa a integrar a ordem econômica, como requisito de viabilidade desta e do alcance dos objetivos a que se presta, ao ensinar que os ecossistemas naturais devem ser preservados $e$, se modificados, usados de maneira sustentável, ou seja, dentro de um modelo de produção, cuja exploração dos recursos naturais permita a manutenção da integridade dos ecossistemas.

Bessa Antunes ${ }^{86}$ trilha o mesmo caminho, situando o Direito Ambiental como um dos ramos do Direito que têm interface com o Direito Econômico:

O Direito Econômico está contido na grande província jurídica do direito público. A característica mais marcante deste ramo do direito público é a interdisciplinariedade, que é facilmente constatável, tendo em vista o grande número de instrumentos e áreas diversas que são submetidos às normas de Direito Econômico. Pode-se dizer que o Direito Econômico é uma espécie de polo, ao redor do qual circulam o Direito Tributário, o Direito Administrativo, o Direito Financeiro, o Direito Ambiental e inúmeros outros.

Em trabalho dedicado ao estudo da valoração econômica diante da mudança do clima, Melissa Furlan ${ }^{87}$ destaca:

Durante muito tempo, buscou-se o desenvolvimento econômico sem a preservação do meio ambiente, o que resultou em um desenvolvimento de forma predadora e poluidora. Contudo, com a valorização da consciência ambiental, constata-se que não basta o crescimento econômico, mas sim que este ocorra de modo a não prejudicar o meio ambiente; mais ainda, constata-se que o desrespeito ao meio ambiente traz consequências extremamente negativas para a sociedade, tanto no plano social como no econômico. Essa conscientização tem contribuído para uma crescente valorização econômica do bem ambiental.

Ora, se é fato que a variável ambiental integra a equação de viabilidade e manutenção da ordem econômica; e se é fato ainda que o Direito Ambiental constitui um

\footnotetext{
${ }^{85}$ SILVA, Américo Luís Martins da. Direito do meio ambiente e dos recursos naturais. São Paulo: Ed. Revista dos Tribunais, 2005. p. 83.

${ }^{86}$ ANTUNES, Paulo de Bessa. Direito ambiental. 7. ed. Rio de Janeiro: Lúmen Júris, 2004. p. 12.

${ }^{87}$ FURLAN, Melissa. Mudanças climáticas e valoração econômica da preservação ambiental. Curitiba: Juruá, 2010. p. 98-102.
} 
ramo (ou uma vertente) do direito que, nos dizeres de Bessa, gravita em torno do Direito Econômico, conclui-se que o trato da questão ambiental, no plano da aplicação de políticas públicas voltadas à sua defesa e preservação, garantindo-se pois o atendimento à sua condição de requisito a uma ordem econômica que atinja seu objetivo de assegurar a todos existência digna, não pode deixar de considerar a valoração econômica desse bem posto sob tutela do Estado.

E de que Estado estamos a falar? Já construímos esse raciocínio acima. Cabe aqui trazer as premissas ali fixadas, e desenvolver alguns pontos e critérios.

Defendemos acima que o legislador constitucional, ao trazer a redação atual ao inciso VI do artigo 170 da Constituição Federal, trouxe à realidade de nosso sistema, no que toca à matéria ambiental, de forma expressa, a função de realização da intervenção qualitativa na ordem econômica, a que se refere Canotilho, tendo como objetivo finalístico, entendida a expressão "defesa do meio ambiente" na sua adequada dimensão, o alcance da preservação dos recursos naturais para as presentes e futuras gerações, em clara busca da sustentabilidade.

Em linha com essa função de intervenção qualitativa que Canotilho atribui ao Estado, mas abordando a questão das formas de intervenção na ordem econômica disponíveis ao Estado sob outra ótica, a da classificação jurídica dessas formas, Eros Grau ${ }^{88}$ denomina de intervenção por indução aquela por meio da qual o Estado manipula os instrumentos de intervenção em consonância e na conformidade das leis que regem o funcionamento dos mercados.

Este Estado é o que, nos dizeres de Bessa Antunes ${ }^{89}$, induz a formação de uma economia social de mercado, conforme demanda, na interpretação do renomado autor, nossa Constituição Federal, dado que, no seu entendimento, os dispositivos constitucionais que tratam da ordem econômica, artigos 170 e seguintes, invocam um sistema econômico que, reconhecendo a prevalência dos mecanismos da economia de mercado, entende que estes não podem ser absolutos e soberanos.

Assim, cabe ao Estado intervir, de modo a preencher suas funções, conforme identificadas por Canotilho, no propósito de participar da busca pela sustentabilidade.

\footnotetext{
${ }^{88}$ GRAU, Eros Roberto. A ordem econômica da Constituição de 1988: interpretação e crítica. 3. ed. São Paulo: Malheiros Ed., 1999. p. 154-156.

${ }^{89}$ ANTUNES, Paulo de Bessa. op. cit., p. 14-16.
} 
Fundamental ter em mente, neste passo, que essa busca pela sustentabilidade implica quebrar um paradigma das relações sociais. Com efeito, é da nossa cultura resolver perdas (decorrentes de ofensa a direito, de danos, ou sob outras modalidades) pela adoção do binômio reparação ou indenização. A reparação, aqui, revela-se na condução do bem lesado ao status quo ante. Já a indenização revelar-se-á, em regra, por meio de pecúnia. Troca-se o bem lesado pelo valor a ele correspondente.

Ora, tal raciocínio não serve ao tema da sustentabilidade. Dado o caráter intergeracional que informa a proteção ambiental, e o mote preventivo, e não reativo, pelo qual deve operar a intervenção qualitativa do Estado, faz-se necessário ter por norte a indução de condutas e posturas de ordem preservacionista do bem que se tutela, e não de sua troca por pecúnia como uma válvula de equalização admissível. Paulo Henrique do Amaral $^{90}$, ao tratar da questão da tributação ambiental, destaca esse entendimento:

Contudo, desenvolvimento sustentável não se pratica apenas com a monetarização dos recursos ambientais ou com sua compensação econômica, mas pela execução de projetos e políticas efetivas de prevenção de eventuais danos ao meio ambiente, redução e recuperação daquilo que já foi degradado. É dentro desse contexto que se deve desenvolver qualquer espécie de política de proteção ambiental; para isso se deve observar os princípios do direito ambiental, como o da precaução, prevenção, cooperação e poluidor-pagador.

O que propomos, neste trabalho, entendemos ser um passo além do que defendeu o autor citado. Sem que se desprestigie os princípios e mecanismos de recondução do meio ambiente lesado ao estado anterior, com a aplicação das necessárias ferramentas de sanção e indenização, quando irrecuperável o bem lesado, entendemos caber ao Estado indutor ir além, para, valendo-se do princípio da sustentabilidade, coordenar a atividade econômica no plano das políticas públicas, pela aplicação, de modo transversal, de políticas públicas outras, de cunho ambiental, de forma que estas moldem aquelas. Essa tarefa de moldar o mercado, na forma do que estipula o artigo 170, VI, da CF, dar-se-á por meio do estabelecimento de indução à conduta positiva, e desestímulo à conduta indesejada, pela aplicação de carga tributária diferenciada.

\footnotetext{
${ }^{90}$ AMARAL, Paulo Henrique do. Tributação ambiental: contributo à política de desenvolvimento sustentável no Brasil. Revista de Direito Ambiental, São Paulo, v.13, n. 50, p. 226, abr./jun. 2008.
} 


\section{(3) O Direito Ambiental e o Direito Tributário - a materialização da intervenção qualitativa na ordem econômica}

Visto caber ao Estado intervir na ordem econômica - a intervenção qualitativa para estimular e induzir condutas, exercendo portanto uma influência sobre o mercado, para assim contribuir à busca da sustentabilidade, cumpre agora debater a forma de se implementar essa função do Estado.

Partimos da já citada lição de Eros Grau, que entende aplicar-se aqui a intervenção por indução, que é aquela por meio da qual o Estado manipula os instrumentos de intervenção em consonância e na conformidade das leis que regem o funcionamento dos mercados.

Nos dizeres de Washington Peluso Albino de Sousa ${ }^{91}$, o Estado regula a economia, fazendo-o por medidas legais executivas de fiscalização da prática econômica privada dos mercados, de incentivo a essa atividade por parte da iniciativa privada, suplementando-a e planejando-a pela introdução de medidas que vão além do funcionamento autorregulador do mercado pelas suas próprias forças.

Tais instrumentos são os tributos. Conforme a lição de Gloria Alarcón García ${ }^{92}$, a fiscalidade ambiental ou tributação ambiental, expressões usadas comumente para designar o uso dos tributos para impor ou induzir o mercado a uma determinada conduta, deve ser entendida como um conjunto de tributos, o de componentes tributarios, previstos em un ordenamiento tributario, dirigido a la consecución de um fin extrafiscal: preservar y mejorar el medio ambiente. Esses tributos ou componentes tributários atiendem, básicamente, al principio de justicia ecológica.

Cabe aqui, neste passo, um alerta: a busca de exemplos de outros países, para que se pense em propostas para nosso país, no que toca ao trato tributário da questão ambiental, deve ser recebida, sempre, com cuidado. Isto porque, conforme ensina Heleno Taveira Tôrres ${ }^{93}$,

\footnotetext{
${ }^{91}$ SOUSA, Washington Albino Peluso de. Primeiras linhas de direito econômico. 4. ed. São Paulo: LTr, 1999. p. 330.

${ }^{92}$ ALARCÓN GARCÍA, Gloria. La fiscalidad ambiental: el fenómeno tributario y su relación com el medio ambiente. In: GIMÉNEZ, Teresa Vicente (Coord.). Justicia ecológica y protección del medio ambiente. Madrid: Ed. Trotta, 2002. p. 265-266.

${ }^{93}$ TÔRRES, Heleno Taveira. Da relação entre competências constitucionais tributária e ambiental - os limites dos chamados "tributos ambientais". In: Ed., 2005. p. 97. (Org.). Direito ambiental tributário. São Paulo: Malheiros
} 
"Em matéria de direito tributário ambiental, há trabalhos estrangeiros sobremodo relevantes, escritos pelos mais eminentes autores, mas nenhum destes pensados sob a égide de uma constituição que, em matéria tributária, tenha sido tão analítica quanto a nossa, com prévia identificação das espécies de tributos e respectivas materialidades determinantes do exercício de competência e que se vê, ainda, sujeita à observância de normas gerais sobre legislação tributária e uma série de princípios, imunidades e regras objetivas, tudo no plano constitucional. Esse é um paradigma difícil de alcançar e certamente um óbice ao aproveitamento da experiência externa, o que nos impõe a uma construção sobremodo original no trato dessas questões."

Interessante notar que a nota trazida pelo Professor Tôrres soma-se, para efeitos deste trabalho, ao fato de que a doutrina nacional, quando aborda a questão dos "tributos ambientais", invoca, salvo raríssimas exceções, o princípio do poluidor-pagador - e em pouquíssimos casos o princípio do usuário-pagador - como vetor orientador do estabelecimento do tributo como ferramenta de proteção e controle ambiental. Tal circunstância torna ainda mais complexa a tarefa de invocar exemplos para dar fundamento ao que aqui se propõe. Daí por que muito do que se invocará aqui como suporte às teses desenvolvidas dirá acerca de aspectos gerais do tema ambiental tributário, ou tratará de cada uma dessas vertentes - a tributária e a ambiental - separadamente.

Feito o alerta, retomemos o ponto, tomando o ensinamento de Alarcón García como ponto de partida. Para que se possa identificar os tributos em espécie adequados à tarefa proposta, em sede geral e considerados os setores (energia e florestas) eleitos para este trabalho, entendemos fundamental passar por um exame analítico que apresenta as seguintes etapas:

(3.a) o conceito de "justo" no contexto deste trabalho, para fins do exame dos tributos em espécie aplicáveis às hipóteses gerais, do setor de energia e do setor de florestas;

(3.b) A finalidade dos tributos como marco identificador;

(3.c) o sentido da aplicação do tributo: impositiva ou seletiva;

(3.d) as espécies de tributo e sua adequação aos sentidos da sua aplicação.

Passemos à consideração de cada um desses pontos. 


\section{(3.a) o conceito de "justo" no contexto deste trabalho, para fins do exame dos tributos em espécie aplicáveis às hipóteses geral, do setor de energia e do setor de florestas}

Dissemos, acima, que o justo é aquele estado de coisas, aquela situação ou condição em que se atende aos elementos que compõem a condição de busca da sustentabilidade, e ainda dos objetivos da ordem econômica, e os objetivos da Constituição. Não se tendo essa condição, não se terá implementado o sistema constitucional pretendido.

Mas há que se ter em conta, no contexto do "justo", a questão do tributo. O tributo não pode exceder seus objetivos, não pode exceder a medida necessária à consecução de seu objetivo, sob pena de retirar ao contexto em que se insere a condição de "justo".

E, aqui, entendemos ser fundamental ter-se em mente, para o propósito deste trabalho, que estamos a laborar sob o entendimento de que o sistema de comando e controle, e o princípio do poluidor-pagador, já recebem o devido tratamento pela legislação, tendo-se revelado incompletos. Daí por que, ao abordarmos neste tópico e nos seguintes deste trabalho a questão dos tributos como instrumento de implementação da intervenção do Estado na ordem econômica, o faremos sempre exclusivamente sob o olhar da complementação ao sistema existente pelo estabelecimento de mecanismos de ordem diversa, sem cogitar da aplicação de ferramentas, no âmbito tributário, que tenham o condão de aperfeiçoar ou complementar essa vertente, a do comando e controle, informada pelo princípio do poluidor-pagador.

Eis, pois, que o "justo", para os fins que proporemos, será a obtenção da indução, do estímulo a uma determinada conduta, diante de uma realidade que se entende deva ser modificada, sem que com isso, no plano geral, se onere excessivamente as atividades atingidas pela proposta.

E o conceito de "justo" que aqui se adota insere-se em um contexto maior, o da justiça social que prega nossa Constituição e que, quando aplicada à vertente tributária, ou seja, quando constituindo a justiça tributária, deve exceder a mera justiça distributiva, que de ordinário informa o direito tributário, para ir além, desempenhando um papel de indução e de modificação da estrutura social, configurando uma justiça estruturante (gestaltende gerechtigkeit), conforme defende Klaus Vogel ${ }^{94}$.

\footnotetext{
${ }^{94}$ VOGEL, Klaus. Steuergerechtigkeit und soziale Gestlung. Deutsche Steuerzeitung, p. 410, Oktober, 1975.
} 
No plano específico aos setores objeto de exame neste trabalho, no que toca ao setor de energia, será vinculada ao justo a norma tributária que induza o investimento e desenvolvimento de projetos de geração de energia que se utilizem de fontes alternativas, as fontes ditas limpas, enquanto, para o setor florestal, andará de mãos dadas com o justo a proposta que acarrete preservação de nossas florestas, com o abandono de sua derrubada.

Este, pois, o norte a observar daqui por diante, neste trabalho.

\section{(3.b) A finalidade dos tributos como marco identificador}

A doutrina ensina que um critério eficiente de identificação do objetivo do exercício da competência para instituir tributos é o da finalidade, pelo qual se divide esses objetivos entre (ii.a.2.1) fiscais; (ii.a.2.2) parafiscais; e (ii.a.2.3) extrafiscais.

A finalidade fiscal é verificada quando o tributo possui fins arrecadatórios de recursos financeiros. A finalidade será arrecadatória/redistributiva, destaca Claudia Dias Soares ${ }^{95}$.

Já os tributos de perfil parafiscal são aqueles que visam o custeio de atividades paralelas à da administração direta, ao passo que os tributos de índole extrafiscal são aqueles que visam à intervenção na economia, estimulando ou desestimulando certas atividades.

Interessa-nos, para o propósito deste trabalho, considerar os tributos de índole extrafiscal, sob a perspectiva de seu uso como instrumento de efetiva intervenção qualitativa [conforme Canotilho] ou indutora [vide Eros Grau] na ordem econômica, de forma a direcionar/induzir condutas e comportamentos que propiciem o atendimento aos objetivos, no que toca aos setores de energia e florestas, postos na Lei n ${ }^{\circ}$. 12.187/2009.

Nosso propósito, portanto, é claro e restrito.

\footnotetext{
${ }^{95}$ SOARES, Claudia Dias. O imposto ambiental: direito fiscal do ambiente. Coimbra: Almedina, 2002. p. 12-13.
} 


\section{(3.b.1) o esclarecimento necessário}

Antes de nos debruçarmos sobre os tributos cuja finalidade revela-se extrafiscal, no entanto, convém destacar algumas considerações, de ordem geral, que permitem situar, com clareza, os efeitos, totalmente diversos, de cada uma das espécies de finalidades dos tributos, quando aplicados estes ao tema do meio ambiente. Desse exercício, verificar-se-á a vinculação de cada uma dessas espécies de finalidade dos tributos a princípios que regem o trato da questão ambiental, podendo-se assim identificar a diversa ordem finalística da cada caminho escolhido.

Para que se possa isolar cada um desses caminhos, no âmbito do uso dos tributos em favor da defesa e preservação do meio ambiente, convém identificar as hipóteses de uso dessa ferramenta, sob outros prismas, em que se terá o benefício, em termos abrangentes, à consecução da defesa e preservação ambiental, mas não sob o enfoque do direcionar/induzir que nos interessa verificar.

A questão, a nosso ver, toca a um ponto crítico no que respeita à forma como se aborda o trato da questão ambiental. O método tradicional de abordagem, que dominava o pensamento nas décadas de 1970, no plano mundial, e ainda a de 1980, no plano nacional, fundava-se primordialmente no princípio do poluidor-pagador, na sua acepção de controle por imposição de condutas à sociedade, e atuava, na sua aplicação, sob o binômio do controle prévio, exercido por meio do regramento e limitação por intervenção na atividade econômica (comando e controle), e pela internalização dos custos e repressão ao resultado indesejado pela sociedade, a externalidade negativa caracterizada como dano (a reparação).

Vem bem a propósito o que se relata na obra coletiva Taxation for Environmental Protection $^{96}$, acerca da abordagem que se dava ao uso dos tributos em prol da proteção ambiental em países europeus e nos Estados Unidos da América, demonstrando que, no conceito utilizado inicialmente, o uso da ferramenta tributária veio a materializar a internalização do custo ambiental, para o que, no nosso sistema, apresenta-se como melhor instrumento a taxa, vinculada ao princípio do poluidor-pagador:

The second fundamental strategy, articulated by a number of environmental economists, viewed pollution and other damage to the environment as external costs of economic activities that were not properly accounted for in free market decisions and therefore resulted in

\footnotetext{
${ }^{96}$ ERIKSSON, Asbjörn; HERTZOG, Robert; TILEY, John; WILLIAMS, David; ZEZSCHWITZ, Friedrich von. Taxation for environmental protection, New York: Quorum Books, 1991.
} 
'market failures'. From this economic viewpoint, the preferred solution is to devise various legal and institutional mechanisms to correct the failures of the market so as to force private parties in the market to internalize into their prices all of the environmental costs of their products.

O raciocínio caminhava de mãos dadas com as teorias de Pigou, já acima citadas neste trabalho. Interessante verificar o que diz Perelló Sivera ${ }^{97}$ acerca da aplicação do princípio do poluidor-pagador, sob a forma de imposição de taxas, em reflex a tal raciocíno:

Con el impuesto pigouviano los costes externos son internalizados cumpliendo el principio de causalidad. Es decir, el que contamina, paga.

Boa parte da doutrina especializada, ao tratar da atuação dos tributos no campo da defesa e preservação ambiental, prende-se a essa esfera de atuação do princípio do poluidor-pagador, para entender que a tributação, em matéria ambiental, prestar-se-ia ao custeio dos serviços públicos voltados ao tema da implementação dessa estrutura, do comando e controle, assim como para fazer frente aos riscos assumidos pelo empreendedor, pelo exercício da atividade escolhida. É o sentido impositivo do princípio do poluidorpagador, revelado na atividade tributária, conforme ensina José Marcos Domingues ${ }^{98}$ :

Pertinente aqui relembrar o que acima se disse sobre as duas facetas do princípio do poluidor-pagador: num sentido impositivo o princípio impõe o dever estatal de cobrar do poluidor (no caso, tributar) contribuições públicas em função de sua atividade objetivamente poluidora de forma a fazê-lo arcar com o custo dos serviços públicos gerais ou específicos necessários à preservação e recuperação ambientais ou à fiscalização e ao monitoramento ambientais (nesta perspectiva, o princípio se pode adequar à tributação fiscal).

Vale aqui destacar que, nesta perspectiva impositiva, o princípio do poluidorpagador encerra a busca ao "ótimo de Pareto". Jorge Henrique de Oliveira Souza ${ }^{99}$ trata do tema, citando Pigou:

\footnotetext{
${ }^{97}$ SIVERA, J. Perreló. Economia ambiental. Universidad de Alicante, 1996.

${ }^{98}$ DOMINGUES, José Marcos. op. cit., p. 56.

${ }^{99}$ SOUZA, Jorge Henrique de Oliveira. Tributação e meio ambiente. Belo Horizonte: Del Rey, 2009. p. $110-111$.
} 
Segundo a Teoria de Pigou [o autor refere-se à obra "Economia do BemEstar", de Arthur Cecil Pigou], a solução das externalidades negativas, entre elas o dano ambiental, estaria, como aponta esse professor [o autor refere-se ao Professor Zilton Luiz Macedo] em tornar privados esses custos sociais mediante a adoção de instrumentos econômicos que simulam um "preço" que os poluidores devem incorporar aos seus custos privados, internalizando assim as suas externalidades. Nesse caso, as modificações nos custos induzem os produtores a um novo ponto de equilíbrio, alcançando, dessa forma, o "ótimo de Pareto". (os comentários entre chaves são nossos).

Gloria Alarcón García ${ }^{100}$ afirma enquadrarem-se, os tributos vindos sob esse princípio, e atendendo às finalidades fiscal e parafiscal, na fiscalidade ambiental direta, na classe sob a qual se encontram os tributos sobre emissões (ou ainda de ordenação ou puros) e os tributos sobre produtos. Veja-se o comentário da autora sobre esses tributos e sua aplicação, do qual se conclui estarem fundados no princípio do poluidor-pagador:

Los tributos sobre emissiones, también denominados de ordenación o puros, gravan directamente las descargas contaminantes al medio, empleando para ello um método de determinación directa de la base imponible.

De outra parte cabe la posibilidad de diseñar um tributo ambiental eligiendo como hecho imponible la producción o el consumo de determinados bienes cuyo uso es nocivo para el medio natural. Estos últimos reciben la denominación genérica de tributos sobre productos (...)

Ora, o uso do tributo como instrumento para, sob o manto do princípio do poluidorpagador em sua visão tradicional, cuidar de onerar as descargas contaminantes, ou ainda o uso de bens nocivos ao meio ambiente, significa trabalhar sob perspectiva perversa, posto que a aplicação desses tributos, se de um lado faz-se necessária para os fins arrecadatórios, de internalização de custos, e de financiamento público a que se presta, de outro lado será sempre proporcional à ocorrência dos fatos que se busca evitar que ocorram: quanto maiores as emissões poluentes, maiores os valores arrecadados, ao mesmo tempo que, quanto maior o uso de bens e produtos nocivos ao meio ambiente, maior será a arrecadação do Estado.

\footnotetext{
${ }^{100}$ ALARCÓN GARCÍA, Gloria. op. cit., p. 268-270.
} 
Dispensa demonstração a afirmação de que a lógica verificada é perversa: o Estado arrecada mais com a maior degradação e risco ambientais. Não se pode, portanto, ter essa ordem de mecanismo como prevalente e bastante, especialmente diante da opção feita pelo legislador constitucional, no que toca ao meio ambiente, de estabelecimento de uma nova ordem (diversa do pensamento tradicional liberal), sob a qual se busca pela defesa e preservação do meio ambiente o alcance da sustentabilidade, calcada fundamentalmente na apropriação e uso racional dos recursos naturais, almejando-se sempre sua preservação, para que não se deixe inviabilizado às futuras gerações o acesso aos recursos naturais. Celso Fiorillo e Thaís do Carmo ${ }^{101}$ bem destacam essa inovação posta em nossa Constituição:

O legislador expurgou de nossa sociedade o antigo sistema liberal, chamado capitalismo selvagem, adotando um modelo intervencionista, de índole Keynesiana, totalmente balizado por princípios, tendo como objetivo a manutenção e efetivação da vida com qualidade, bem como o desenvolvimento econômico do nosso país.

O alcance do que prega a Constituição, dessa nova ordem, passa necessariamente pelo trato da questão ambiental sob a mão forte do comando e controle, e da internalização de custos pela ferramenta impositiva. Mas não só por esse caminho se chegará ao resultado almejado, conforme dito. Outros mecanismos e ferramentas serão necessários.

Mais ainda: quando se estabelece uma carga tributária a ser aplicada sobre emissões poluentes e produtos, conforme posto acima, ter-se-á como de necessária identificação, sempre, a fonte causadora da emissão, e o usuário do produto, como requisito à determinação do agente passivo da incidência da obrigação tributária.

Esses tributos não trazem trato ou solução para a questão do custeio da recuperação de áreas contaminadas ditas “órfãs”, que são as áreas contaminadas para as quais, diante da não identificação do agente causador da contaminação, não se pode identificar o responsável pela sua remediação. Resta relegado ao Estado o trato e recuperação dessas áreas, impondo-se para sua viabilização a criação de mecanismos de arrecadação, para seu custeio, por meios distintos dos impostos sobre emissões ou produtos. São os fundos de recuperação, dos quais trataremos mais adiante.

\footnotetext{
${ }^{101}$ FIORILLO, Celso Antônio Pacheco; CARMO, Thaís Maria Leonel do. Desenvolvimento sustentável: a ordem econômica do capitalismo e a questão do meio ambiente na Constituição Federal de 1988 - Art. 170, VI. In: MARQUES, José Roberto (Org.). Sustentabilidade e temas fundamentais de direito ambiental. São Paulo: Millenium, 2009. p. 67.
} 
O exercício da atividade fiscal ou parafiscal, no que toca à contribuição à defesa e preservação do meio ambiente com vistas à construção da busca da sustentabilidade, portanto, soma-se ao sistema de comando e controle de que tratamos antes, integrando, então, a teia de instrumentos pelos quais o Estado busca a implementação do princípio do poluidor-pagador em sua interpretação tradicional, de internalização de custos e externalidades negativas decorrentes do exercício das atividades produtivas.

Assim é que esses tributos, tais como a Taxa de Controle e Fiscalização Ambiental - TCFA, cujos recursos obtidos prestam-se ao custeio do sistema de controle ambiental, assim como figuras tributárias outras de tal escol, não integram o tema de interesse deste trabalho, e serão deixados de lado. Ater-nos-emos aos tributos que, porquanto extrafiscais, prestam-se não a onerar a atividade degradadora/poluidora, mas a induzir a conduta e comportamento que atendem ao objetivo da defesa e preservação do meio ambiente.

\section{(3.b.2) a função extrafiscal dos tributos - o cerne do exame proposto}

Em apartado aos tributos que se inserem no âmbito das funções fiscal e parafiscal, interessam ao estudo aqui proposto os tributos inseridos no contexto da função extrafiscal. O festejado Professor Paulo de Barros Carvalho ${ }^{102}$ define o que seria a extrafiscalidade dos tributos:

(...) a compostura da legislação de um tributo vem pontilhada de inequívocas providências no sentido de prestigiar certas situações, tidas como social, política ou economicamente valiosas, às quais o legislador dispensa tratamento mais confortável ou menos gravoso. A essa forma de manejar elementos jurídicos usados na configuração dos tributos, perseguindo objetivos alheios aos meramente arrecadatórios, dá-se o nome de extrafiscalidade.

A lição de Alfredo Augusto Becker ${ }^{103}$ igualmente reclama destaque, escolhendo-se aqui trecho em que qualifica a razão de ser da função extrafiscal dos tributos:

O Direito Tributário não tem objetivo (imperativo econômico-social) próprio; ou melhor, como todo o Direito positivo, o Direito Tributário tem a natureza instrumental e seu 'objetivo próprio' (razão de existir) é ser um instrumento a serviço de uma Política. Esta (Política) é que tem os

\footnotetext{
${ }^{102}$ CARVALHO, Paulo de Barros. Curso de direito tributário. 13. ed. São Paulo: Saraiva, 2000. p. 228.

${ }^{103}$ BECKER, Alfredo Augusto. Teoria geral do direito tributário. 3. ed. São Paulo: Lejus, 2002. p. 596.
} 
seus próprios e específicos objetivos econômico-sociais. Por isso, cumpre lembrar que a tributação extrafiscal serve tanto para a reforma social, como para impedi-la.

A identidade entre a lição de Becker e o mote da alteração constitucional trazida pela EC 42/2003 é nítida: o artigo 170, VI, da Constituição Federal, com a redação que lhe foi conferida, remete ao uso da tributação extrafiscal como ferramenta de indução de uma reforma, a reforma ambiental, para que se passe à postura que demanda a defesa e preservação ambiental vinculada à busca pela sustentabilidade.

A adoção da vertente extrafiscal, para esse fim, é denominada por Gloria Alarcón García $^{104}$ como a fiscalidade ambiental indireta, que assim se define:

Como se ha avanzado en las líneas precedentes, bajo este concepto se engloban todos aquellos componentes del tributo cuya finalidad es modificar los comportamientos de los agentes económicos y contribuyentes en el sentido de preservar o mejorar el medio ambiente. Esto significa que, de esto modo, no se crean figuras tributarias independientes cuya finalidad es medio ambiental, sino que el legislador utiliza los tributos vigentes para introducir en ellos medidas tendentes a la mejora del medio ambiente. Esto es, se produce uma yuxtaposición de las figuras tributarias existentes.

Nos dizeres de José Marcos Domingues ${ }^{105}$, trata-se de aplicar o princípio do poluidor-pagador no sentido seletivo:

Noutro sentido, seletivo, o princípio determina prioritariamente ao Poder Público que gradue a tributação de forma a incentivar atividades, processos produtivos ou consumos "ecologicamente corretos", ou environmentally friendly (literalmente, amistosos, adequados sob a ótica ambientalista, numa palavra, não poluidores), e desestimular o emprego de tecnologias defasadas, a produção e o consumo de bens "ecologicamente incorretos", ou not environmentally friendly (isto é, nefastos à preservação ambiental). É, como se percebe, o campo da tributação extrafiscal.

Ricardo Berzosa Saliba ${ }^{106}$, por fim, denomina essa forma de tributação de ordinatória:

\footnotetext{
${ }^{104}$ ALARCÓN GARCÍA, Gloria. op. cit., p. 274-275.

${ }^{105}$ DOMINGUES, José Marcos. op. cit., p. 57.

${ }^{106}$ FALCÃO, Raimundo Bezerra. Tributação e mudança social. Rio de Janeiro: Forense, 1981. p. 291-292.
} 
A tributação ordinatória propicia a redução da dualidade da sociedade e das economias pouco desenvolvidas, inclusive pela melhoria das técnicas produtivas e criação de condições sociais e políticas que facilitem o crescimento econômico e contribuam para fazê-lo autossustentável, até mesmo para incrementá-lo.

Parece-nos claro que, considerado o princípio da sustentabilidade, e vista a saturação do sistema fundado no princípio do poluidor-pagador, a alteração trazida ao texto constitucional pela EC 42/2003 não poderia ser mais feliz e oportuna, dado ter aberto a perspectiva de desenvolvimento de políticas públicas voltadas ao trato da questão ambiental fundadas não mais nas ferramentas à larga aplicadas, mas (i) centrada no princípio da sustentabilidade, e não mais exclusivamente no poluidor-pagador; (ii) materializada sob a natureza extrafiscal, deixadas as vertentes fiscal e parafiscal como base já solidificada; e (iii) com o mister de alcançar o estímulo e a indução do desenvolvimento de segmentos da economia que tenham em sua raiz, sejam marcados pelo perfil da melhor adequação, em relação às atividades similares de mesmo fim, à busca da sustentabilidade, notadamente no que toca ao respeito à função e caráter intergeracional do sistema de proteção e conservação ambiental vigente.

\section{(3.b.3) alguns comentários salutares à consideração do uso dos tributos de índole extrafiscal - superação de potenciais questões e dúvidas para o exame dos casos concretos que se passará a realizar mais adiante}

Alguns aspectos atinentes à extrafiscalidade, considerando o objeto deste trabalho, nos parece merecerem comentários aqui, em sede preliminar ao enfrentamento da questão específica - a aplicação dos tributos de índole extrafiscal ao trato da busca de atendimento às metas de redução de emissões de GEE para os setores de energia e florestas - a que nos dedicaremos, de forma a desde logo afastar eventuais dúvidas quanto à coerência e ao sentido lógico do que se proporá.

Bom dizer, desde logo, que o uso de tributos com fins extrafiscais não constitui novidade alguma. Heleno Taveira Tôrres ${ }^{107}$ destaca o ponto, afirmando que, para o trato da questão ambiental no Brasil, os tributos surgem com grande força, o que não deve causar

\footnotetext{
${ }^{107}$ TÔRRES, Heleno Taveira. Da relação entre competências constitucionais tributária e ambiental - os limites dos chamados "tributos ambientais", cit., p. 99.
} 
nenhum espanto, pois não se trata de qualquer novidade o recurso a tributos com 'fins extrafiscais', como ainda se usa dizer. Desde priscas épocas o tributo vem sendo utilizado para práticas de tal natureza.

\section{(3.b.iv) o princípio informador da aplicação dos tributos de índole extrafiscal no atendimento aos preceitos constitucionais relativos à ordem econômica e ao meio ambiente}

Queremos aqui, como um primeiro aspecto a visitar em sede preliminar ao enfrentamento da questão específica, trazer uma contribuição ao debate dos fundamentos do Direito Ambiental, no que toca à sua interface com o Direito Tributário. Com a inserção do princípio do direito ao meio ambiente ecologicamente equilibrado, posto em nosso texto constitucional, e do direito ao desenvolvimento sustentável (ou, no mínimo, à busca de tal condição) como corolário deste, entendemos ser equivocada a afirmação de que o uso de tributos de índole extrafiscal representaria aplicação do princípio do poluidor-pagador em nosso sistema.

Isto porque, em nosso entender, a internalização dos custos ambientais e das externalidades negativas da atividade degradadora/poluidora, esta sim, objeto de aplicação do princípio do poluidor-pagador, e que atinge diretamente o exercício individualizado de atividade que pode trazer a degradação/poluição como resultado indesejado, difere, em essência, do estabelecimento de mecanismos pelos quais, por via indutiva, se direcione a economia (e, como diremos mais adiante, o capital de investimento), como um todo, para um determinado caminho. $O$ que se vê nessa hipótese última não tem nada de internalizador de custos, mas sim de indutor de conduta, tarefa que é - ou deve ser - na outra face (na atividade alternativa à mais próxima da sustentabilidade, que se quer induzir) do segmento em que se atua, imposta à atividade que se quer desestimular em prol da atividade de perfil mais próximo à sustentabilidade.

Parece-nos, pelo posicionamento da doutrina especializada do direito ambiental, que essa vertente indutiva, positiva, e de caráter geral, não individualizado, não encontra guarida no princípio do poluidor-pagador, identificando-se, aí sim, com o princípio do direito ao meio ambiente ecologicamente equilibrado e do desenvolvimento sustentável como norte à nossa sociedade. 
De toda forma, por um caminho ou por outro, o que importa é destacar que, com o uso dos tributos de índole extrafiscal, pode-se complementar aquela estrutura já existente em nossa sociedade, desde 1981, pela qual se adota instrumentos de repressão, controle e reparação diante do risco ambiental.

\section{(3.b.v) a ausência de ofensa aos princípios fiscais}

Outro ponto que está a reclamar menção, como aspecto preliminar ao enfrentamento do objeto concreto deste estudo, é a questão da ausência de ofensa aos princípios fiscais, pelo uso dos tributos de índole extrafiscal.

O ponto tem ordem genérica, ou seja, não se apega exclusivamente ao uso da extrafiscalidade como ferramenta de alcance de objetivos vinculados ao Direito Ambiental, e reclama aqui menção para que não se cogite da ocorrência de ofensa aos princípios fiscais ao depois, quando mais adiante tratarmos das propostas específicas à implementação do objetivo de redução das emissões de GEE para os setores de energia e florestas.

Sacha Calmon Navarro Coelho ${ }^{108}$ trata do tema com clareza:

De saída, igualdade na tributação, capacidade contributiva e extrafiscalidade formam uma intrincada teia.

(...)

O princípio, vê-se, cede o passo às políticas tributárias extrafiscais, mormente as expressamente previstas na Constituição. Quer dizer, onde o constituinte previu a exacerbação da tributação para induzir comportamentos indesejados, é vedada a arguição do princípio do não confisco tributário, a não ser no caso-limite (absorção do bem ou renda).

Não difere o entendimento de Misabel Derzi:

A Carta Fundamental brasileira, ao contrário da alemã, estabelece as bases em que se assenta o Estado Democrático de Direito, fixando-lhe metas de justiça e igualdade social e, coerentemente, faz repercutir o princípio no Capítulo do Sistema Tributário. Pessoalidade, seletividade, extrafiscalidade e progressividade são princípios que espelham a busca da maior justiça tributária.

${ }^{108}$ COELHO, Sacha Calmon Navarro. Manual de direito tributário. Rio de Janeiro: Forense, 2001. p. 130. 
Bem se vê, não haverá, no exercício da atividade extrafiscal, ofensa aos princípios que regem a atividade fiscal.

\section{(3.b.vi) segurança jurídica - preceito fundamental}

Transversal a tudo o quanto até aqui sustentado é o ponto da segurança jurídica. Não se terá um sistema que atenda ao quesito do "justo", e nem mesmo que seja válido, se desatendidos os critérios estruturais de validade e eficácia do tributo ambiental.

Em linhas gerais, o que se quer dizer é que estamos diante de uma vinculação constitucional expressa: a defesa e preservação do meio ambiente (como ferramenta de busca da sustentabilidade). Este é o motivo constitucional que orienta o estabelecimento, observados os limites constitucionais ao poder de tributar, da criação do tributo ambiental.

Os princípios constitucionais determinantes das competências de ordem ambiental e tributárias deverão estar atendidos, sob pena de se propor, no tópico próprio deste trabalho, em que se cuidará da proposta para a implementação das metas de redução de GEE para os setores de energia e florestas, a adoção de modelos de tributos que poderão se revelar inválidos e ineficazes, na acepção jurídica do termo, porquanto desvinculados desses princípios e princípios constitucionais de competência.

A lição de Celso Antônio Bandeira de Mello ${ }^{109}$ indica o caminho que devemos aqui tomar por orientação:
A lei não pode conceder tratamento específico, vantajoso ou desvantajoso, em atenção a traços e circunstâncias peculiarizadoras de uma categoria de indivíduos se não houver adequação racional entre o elemento diferencial e o regime dispensado aos que se inserem na categoria diferençada.
(...)
O vínculo de correlação suprarreferido seja pertinente em função dos interesses constitucionalmente protegidos, isto é, resulte em diferenciação de tratamento jurídico fundada em razão valiosa - ao lume do texto constitucional - para o bem público.

\footnotetext{
${ }^{109}$ BANDEIRA DE MELLO, Celso Antônio. Conteúdo jurídico do princípio da igualdade. 3. ed. São Paulo: Malheiros Ed., 1999. p. 39-41.
} 
No caso concreto, a razão valiosa a permitir o tratamento diferenciado reside no inciso VI do artigo 170 da Constituição Federal. Ao abrigo de tal dispositivo é que, para o cumprimento do quanto posto na Política Nacional sobre Mudança do Clima, no tocante à redução das emissões setoriais de GEE, proporemos a adoção de mecanismos tributários de indução, sempre cuidando para não desbordar dos limites constitucionais atinentes às competências ambientais e tributárias, bem como aos princípios informadores de ambas.

\section{(4) Normas jurídicas indutoras}

Defendemos, aqui, que a adoção de normas tributárias indutoras é o caminho adequado para, em complementação ao sistema de comando e controle já vigente, adotado como centro de nossa Política Nacional do Meio Ambiente, possamos alcançar um degrau acima, movimentando o ordenamento de uma ferramenta vinculada ao princípio do poluidor-pagador, para vinculá-lo, de forma mais abrangente, ao princípio da sustentabilidade.

A indicação de como se poderá realizar essa transformação no perfil de nosso sistema, a nosso ver, é a contribuição que podemos dar ao debate da questão ambiental sob o prisma das relações econômicas e do Direito Tributário. Em outras palavras, o que buscamos aqui é estabelecer os elementos cuja adoção permita ir do pontual ao geral, do controle individualizado da atividade produtiva tomada sob a visão pontual ao estímulo ao desenvolvimento mais adequado - sob a perspectiva da sustentabilidade - de setores da economia como um todo, em acordo não mais a regras específicas de controle das externalidades negativas, mas sob a perspectiva de viabilidade da implementação de políticas públicas aplicadas de forma ampla, cujos objetivos se alcançará não por meio da tarefa de deprimir o indesejado, mas de induzir o pretendido (ainda que tenha o efeito indireto de deprimir o indesejado).

Esse cenário que defendemos, em que o Estado adota posturas de indução [estímulo] à economia a partir de premissas vinculadas à sustentabilidade, deve observar como diretrizes duas condições necessárias e indispensáveis ao sucesso de seu propósito, que conforme destaca Villela Souto ${ }^{110}$, são (a) um ambiente que permita viabilizar as

\footnotetext{
${ }^{110}$ VILLELA SOUTO, Marcos Juruena. Estímulos positivos. In: CARDOZO, José Eduardo M.; Queiroz, João Eduardo L.; SANTOS, Márcia Walquíria B. dos (Orgs.). Curso de direito administrativo econômico. São Paulo: Malheiros Ed., 2010. v. 2, p. 128 e ss.
} 
atividades que se pretende induzir, do ponto de vista da lucratividade, e (b) um sistema que garanta segurança jurídica para os negócios privados.

Para que se desenvolva esse raciocínio, fundamental compreender o que seriam, e como se aplicam, as normas tributárias indutoras.

\section{(4.a) conceito e viabilidade das normas indutoras}

Indução, ensina Caldas Aulete ${ }^{111}$, é a ação de induzir, induzimento, persuasão, instigação, sugestão, ao passo que o verbo induzir significa instigar, levar ou persuadir a fazer algum ato. A norma jurídica indutora, neste sentir, será aquela que induz, leva a um determinado caminho.

Ao admitirmos que, aplicando o quanto posto no artigo 170, VI, da Constituição Federal, o legislador estabeleça tributos de indução para que nossas políticas públicas voltadas ao trato da questão ambiental - e especificamente da questão da mudança do clima - atinjam seus objetivos, estamos necessariamente afirmando que, de um rol de determinadas atividades possíveis, para um segmento da atividade produtiva, a norma tributária indutora logrará, a um só tempo, estimular a adoção de uma determinada atividade, por indução, e restar desestimuladora da adoção de outras atividades que sejam mais afastadas, ou menos próximas, do conceito da sustentabilidade, que é o vetor de determinação, na proposta que aqui apresentamos, de definição do que será estimulado e do que será desestimulado.

Assim, a norma indutora terá esse viés de desestímulo àquelas atividades que não projeta e induz. Convém aqui pontuar, desde logo, o entendimento de que tal viés não desautoriza ou inviabiliza a norma indutora na forma como a defendemos, de criação de um balanço, ao induzir determinadas atividades, pelo desestímulo reflexo a outras.

Ora, ao estabelecer o artigo 174 da Constituição Federal, ao tratar da atividade do Estado na normatização e regulação da atividade econômica, que tal mister implementarse-á pelas funções de fiscalização, incentivo e planejamento, não se quis vetar a atuação pelo Estado por meio do uso do desestímulo àquelas atividades que, nada obstante lícitas, não encontram a mesma intensidade, no atendimento ao princípio da sustentabilidade, a

\footnotetext{
${ }^{111}$ AULETE, Caldas. Dicionário contemporâneo da língua portuguesa. Rio de Janeiro: Delta, 1958.
} 
que se vinculam as atividades que a norma tributária indutora eleita visa estimular.

Fazemos esse esclarecimento em razão da postura de Marco Aurélio Greco ${ }^{112}$, para quem, dado o teor do citado artigo 174 da Constituição Federal, não seria cabível a adoção de normas de desestímulos, impondo-se reclassificar, levando-se à condição de ilicitude, aquelas atividades consideradas socialmente indesejadas.

Ora, com todo o respeito ao brilhante doutrinador, o fato é que, a uma, condição direta e inescapável do estabelecimento da indução - estímulo - a uma determinada atividade, pela norma tributária indutora, será o desestímulo às atividades outras que, classificadas sob o mesmo segmento, não gozarão do benefício. Assim, negar a possibilidade de a atividade de normatização e regulação realizada pelo Estado adquirir essa característica, do desestímulo, seria negar a possibilidade de adoção da política de estímulo, ofendendo-se, no que toca ao tema de interesse deste trabalho, a previsão constitucional expressa do artigo 170, VI, que usa a expressão tratamento diferenciado, dado o impacto ambiental gerado, a produtos e serviços e de seus processos de elaboração e prestação.

Não há aqui ofensa ao princípio da isonomia, uma vez que o que se está a fazer, na forma do dispositivo constitucional, é tratar de forma diferente os diferentes.

Ora, a duas, o só fato de o texto do dispositivo invocado pelo Professor Greco não trazer a possibilidade de adoção, pelo Estado, de conduta de desestímulo, não autoriza concluir que tal forma de atuação seria vedada. Ora, da combinação dos dispositivos constitucionais já aqui indicados (artigo 170, VI e 174, caput) com o disposto no artigo 225 também da Carta Magna, resta claro que, para se perseguir o mote da sustentabilidade, somente mediante a implementação de instrumentos calcados no binômio "indução (estímulo) - desestímulo" é que se poderá garantir que o Estado "dirija” o capital para as atividades de melhor perfil, no que toca à busca da sustentabilidade como norte.

Parece-nos claro, pois, que o efeito "colateral" da indução não inviabiliza o sistema.

\footnotetext{
${ }^{112}$ GRECO, Marco Aurélio. Contribuições de intervenção no domínio econômico - parâmetros para sua criação. In: (Coord.). Contribuições de intervenção no domínio econômico e figuras afins. São Paulo: Dialética, 2001. p. 9-31.
} 


\section{(4.b) indução compreendida como elemento de implementação de objetivos amplos, de políticas públicas}

O sentido do que se defenderá aqui, neste sub-tópico, é, em linhas diretas, o de que indução e incentivo não se confundem.

Quando se cria normas de incentivo, a nosso ver, opera-se no conceito pontual. O incentivo tem por objetivo estimular certa conduta, de forma a obter um resultado positivo para certa atividade. Tomando-se os exemplos que vemos em nosso sistema, podemos afirmar que, no que toca ao uso de incentivos fiscais voltados ao resultado ambiental, estes em regra observam espectro pontual, ou seja, adotou-se o estímulo a uma determinada conduta para se obter um resultado que, positivo para o meio ambiente, não buscava no entanto alterar posturas, induzir mercados, orientar o capital e o investimento ao caminho da sustentabilidade.

Pode-se dizer que, ao criar o incentivo, o Estado age como regulador, trazendo à atividade humana regulada apenas uma regra adicional de estímulo a uma determinada conduta que, em si, trará um resultado de ordem ambiental. Esse resultado pode ser, por exemplo, o de conservação ou recuperação de áreas florestais sensíveis. Positivo, mas pontual. Não altera condutas de forma a orientá-las em direção à sustentabilidade. O efeito positivo para o meio ambiente é reflexo, e não direto.

Diverso é o caso da indução, no nosso entender. Ainda agindo o Estado como regulador da atividade humana, sua atuação no caso da indução, no entanto, vai além do mero estímulo de ordem pontual a uma conduta que se espera gere um efeito derivado positivo. Trata-se, na indução, de não apenas regular, mas em certa medida dirigir o mercado, pela criação de regras - normas - que, para além de meramente estimular uma conduta, servem como elemento diferenciador entre condutas possíveis, tendo como reflexo da indução a um caminho o desestímulo de outros, levando o mercado a adotar um perfil. Deixa-se de lado o pontual visto no incentivo, e toma-se o caminho do geral. Deixa-se de lado o incentivo à conduta individual que gera resultado ambiental, para se adotar explicitamente o direcionamento do capital a um caminho, que garante à Política Pública atinente a um determinado setor implementar-se com resultados direcionados à sustentabilidade. 
Encontramos suporte ao que defendemos em Marcos Juruena Villela Souto ${ }^{113}$, que ao discorrer acerca da noção jurídica da expressão "estímulos positivos”, destaca:

\begin{abstract}
"A expressão 'estímulos positivos' "[na terminologia que preferimos adotar, indução] ao exercício da atividade econômica privada é bem mais ampla que a de 'fomento' [na terminologia que usamos, incentivo], nela abrangida. Enquanto o fomento é um incentivo ao desempenho de determinada função de interesse do agente fomentador, o estímulo positivo envolve a criação de um cenário favorável aos investimentos." (os trechos entre chaves são nossos)
\end{abstract}

Ou, em outras palavras, deixa-se de lado o princípio do poluidor-pagador como elemento de formulação de regras de internalização de custos, e de incentivo [ou fomento, conforme Villela Souto] a que o poluidor, visto de forma individualizada, adote condutas que gerem, como resultado derivado, um ganho ambiental. Passa-se a abordar a questão de forma abrangente, holística, ordenando-se e direcionando-se [estimulando-se] a atividade humana, de forma genérica, a adotar condutas que atendem aos propósitos das políticas públicas variadas, inserindo-se, nelas, o perfil da sustentabilidade.

\title{
(4.c.) Indução compreendida como instrumento de busca do "justo": Steuerunginstrument
}

Já se defendeu, neste trabalho, o entendimento de que o uso de mecanismos tributários devem buscar o alcance do "justo", para o que cabe ao Estado atuar de forma a conduzir, dirigir a sociedade ao alcance dessa condição justa. Defendemos também, aqui, que o Estado fiscal não pode se tornar insuportável, na esteira dos ensinamentos de Nabais.

Considerada a transição que defendemos e propomos para o trato da questão ambiental, sob a qual já não se intensifica mais a atuação do Estado, no campo tributário, por meio da aplicação de tributos informados pelo princípio do poluidor-pagador, preferindo-se agregar ao quanto já existente, na implementação de políticas públicas, o princípio da sustentabilidade como vetor de orientação, é que surge a seguinte indagação: qual o melhor meio de buscar tal resultado sem gerar ônus fiscal excessivo (o Estado fiscal insuportável a que se refere Nabais), com a promoção, concomitante, da justiça social informadora do "justo" acima debatido?

\footnotetext{
${ }^{113}$ VILLELA SOUTO, Marcos Juruena. op. cit., v. 2, p. 128 e ss.
} 
Parece-nos simples a resposta. Tomando-se por fato que a justiça social - o justo existirá somente desde que mantida uma condição de sustentabilidade ambiental, ou seja, desde que atingida a condição refletida no artigo 225 da Constituição Federal, de preservação da intergeracionalidade do meio ambiente e dos recursos e bens que o integram, mostra-se clara a necessidade de se abordar o tema da proteção do meio ambiente sempre a partir de uma premissa abrangente, geral, dividida em setores da economia, dada a similaridade de resultados que trazem os agentes individualizados desses setores para a sociedade, podendo-se pois trocar-se um por outro, dado o risco ambiental.

Por outras palavras, o controle sobre a atividade humana produtiva, sobre a Ordem Econômica, não mais poderá se dar a partir da ótica do controle ambiental pontual da atividade produtiva potencialmente degradadora, impondo-se seja realizado - esse controle - sob a perspectiva da integração do setor produtivo abordado a partir da premissa das melhores tecnologias e resultados dentre as opções economicamente viáveis postas ao mercado.

Assim, o justo surgirá e restará alcançado e preservado sempre que, além da imposição da régua que divide o legal do ilegal, aplicado de maneira uniforme, a partir da consideração individualizada das atividades produtivas de potencial degradador, for adotada como parâmetro régua - que, por vezes, deverá se comportar como verdadeira Régua de Lesbos, dadas as diferentes circunstâncias e peculiaridades que temos em nosso continental território - outra que, ao invés de traçar a linha divisória entre legal e ilegal, operará sempre acima dessa primeira linha, indicando não a viabilidade do exercício de uma determinada atividade econômica lícita (de que trata o artigo 170 e seu Parágrafo Único, da CF), mas sim apontando para a opção, dentre essas alternativas que alcançam a marca da legalidade, escolhida pelo Estado para atender à premissa da sustentabilidade, materializada, no que concerne ao trato da Ordem Econômica, no atendimento aos termos do artigo 170, VI, da Constituição Federal.

O papel do Estado, portanto, excede a mera regulação do mercado, para direcionálo, por meio de indução, exercendo a intervenção qualitativa referida por Canotilho, ou a intervenção por indução explicada por Eros Grau.

A realização dessa tarefa é que, no nosso entender, somente fará sentido em duas hipóteses: na primeira, e mais simples de se visualizar, a partir do uso dessa "régua" segunda como instrumento de correção de desvios práticos - causados por razões de ordem 
econômica - na aplicação de políticas públicas de proteção ambiental. E a segunda hipótese entendemos ser a de verificação de uma política pública determinada, de regulação de uma atividade que interaja com o meio ambiente, de forma a corrigir as distorções de sua aplicação, identificadas essas distorções a partir de uma análise de cunho ambiental (ou por exemplo de controle da mudança do clima) para as várias tecnologias, formas e métodos de exercício das atividades produtivas enquadradas no setor produtivo objeto de regulação pela política pública que se analisa.

Nesse contexto é que caem como exemplos excepcionais, a nosso ver, as duas políticas públicas que nos propomos a examinar e verificar em que medida se revelam, a uma, distorcidas em sua aplicação, no que toca às políticas públicas voltadas à proteção ambiental, ou, a duas, que se revelam desapegadas a critérios de ordem ambiental postos em políticas públicas de regulação do setor produtivo. No primeiro caso, nada mais adequado do que examinar a política florestal brasileira, notadamente no que tange às dificuldades enfrentadas para implementação dos instrumentos e mecanismos de determinação e conservação de áreas e espaços territoriais especialmente protegidos ${ }^{114}$, de forma a se poder identificar em que medida a abordagem sob o princípio da sustentabilidade poderia trazer instrumentos e mecanismos novos.

E tal análise deverá partir sempre da premissa de que, apesar de estabelecidos os instrumentos de preservação e proteção de determinados espaços territoriais, a eficácia de tais instrumentos é, em regra, posta em cheque por força de questões de ordem econômica - e por vezes questões sociais derivadas de problemas de ordem econômica - que, pela aplicação dos mecanismos aqui propostos, deverão deixar de ser impositivas do descumprimento aos instrumentos de preservação e proteção em questão.

Já no que toca ao segundo caso, entendemos adequado e interessante abordar a questão de nossa política energética, vis-a-vis nossa Política Nacional sobre Mudança do Clima - PNMC.

\footnotetext{
${ }^{114}$ Espaços territoriais especialmente protegidos, nos dizeres de Granziera, "consistem em porções do território - nacional, estadual ou municipal - destacadas das demais pelo Poder Público mediante lei ou decreto, com vistas ã proteção de valores relacionados com o meio ambiente. Em face do interesse público envolvido, relativo ao direito de todos ao meio ambiente ecologicamente equilibrado, esses espaços submetem-se a um regime jurídico especial, de dirieto público, que impõe restrições ao uso do solo e dos outros recursos naturais ali existentes."( GRANZIERA, Maria Luiza Machado. Direito ambiental. São Paulo: Atlas, 2009).
} 
Interessante destacar, desde logo, que, no que toca ao segundo caso, de abordagem de políticas públicas a partir da consideração da variável ambiental, o exercício que propomos passará necessariamente pela consideração de um aspecto que, mesmo na verificação pontual da viabilidade de atividades modificadoras do meio ambiente, por meio do licenciamento ambiental, se realiza com frequência, qual seja, a da viabilidade de adoção de tecnologias alternativas à pretendida pelo empreendedor ${ }^{115}$, de forma a se ter $\mathrm{o}$ melhor cenário de integração entre atividade produtiva e proteção ambiental.

Essa análise a que nos propomos, com a indicação posterior de instrumentos e mecanismos para contribuição à viabilização do alcance dos objetivos de ordem ambiental dessas políticas públicas, visa à consecução do princípio da sustentabilidade que, conforme defendemos, é elemento indissociável do alcance do "justo".

\section{(4.d) a questão do princípio da capacidade contributiva e a viabilidade da tese defendida}

Aspecto fundamental a examinar, para que se justifique a proposta que se formulará, é o da viabilidade da aplicação do mecanismo de indução que defendemos ante ao critério único de distinção de regime e tratamento dos contribuintes.

Heleno Taveira Torres ${ }^{116}$ bem destaca o ponto:

Por ser o princípio da capacidade contributiva o único critério admitido pela Constituição para distinções de regimes e tratamentos entre contribuintes, quando estes se encontram em condições análogas, o recurso ao exercício do poder de polícia, salvo para o caso de criação de taxas (art. 145, II, CF), como meio para fundamentar efeitos de extrafiscalidade a qualquer situação, somente poderá ser aplicado nos exíguos casos para os quais a Constituição autoriza seu uso, a exemplo das hipóteses do art. $153, \S 1^{\circ}$, da CF, das contribuições de intervenção no domínio econômico, da progressividade, ou mesmo da seletividade no IPI e no ICMS.

O cuidado que se deve tomar ao se propor um sistema vinculado ao princípio da sustentabilidade, portanto, é o mesmo que se adotou na introdução do princípio do

\footnotetext{
${ }^{115}$ Com efeito, o licenciamento ambiental, quando realizado sob o procedimento da realização do Estudo Prévio de Impacto Ambiental - EIA, tem por um de seus pilares a consideração das diferentes tecnologias de que se poderá servir o empreendimento pretendido. A Resolução $\mathrm{n}^{\circ}$ 1, de 23.1.1986, do Conselho Nacional do Meio Ambiente - CONAMA, impõe a realização de tal exercício, conforme seu artigo $5^{\circ}$, inciso I.

${ }^{116}$ TÔRRES, Heleno Taveira (Org.). Direito ambiental tributário. São Paulo: Malheiros Ed., 2005. p. 138.
} 
poluidor-pagador como elemento indutor do trato tributário das atividades econômicas, conforme destaca Nabais:

Designadamente está de todo arredada a hipótese de promover reformas fiscais ambientais que tenham a pretensão de substituir a generalidade dos actuais impostos por impostos ecológicos, conduzindo assim a sistemas fiscais pautados pelo princípio de quem polui paga em vez do conhecido princípio da capacidade contributiva.

O ponto, pois, é não afetar regime e tratamento dos contribuintes a partir de critério diverso daquele estabelecido, que é o da capacidade contributiva. Fundamental destacar, aqui, que qualquer método outro de distinção entre contribuintes, para efeito de implementação do princípio da sustentabilidade como vetor de trato tributário das atividades de risco, feriria o conceito do justo ao qual nos apegamos ao longo deste trabalho. Isso porque é o princípio da capacidade contributiva o critério de distinção entre contribuintes que dá a noção de justo ao sistema - quem pode mais, paga mais, e o custeio das atividades do Estado, assim como a arrecadação parafiscal e extrafiscal, vincula-se à maior disponibilidade de recursos de quem contribui.

Como então trazer ao sistema uma nova variável, sem ferir esse princípio fundamental?

Entendemos ser simples a resposta: o regime e o tratamento dado a um determinado contribuinte será ofensivo ao justo quando se criar uma situação de desequilíbrio, em que iguais são tratados de forma desigual, ou desiguais são tratados de forma igual.

Assim, para que o trato tributário vinculado à inserção transversal de uma política pública de ordem ambiental a um determinado setor da economia ou tipo de atividade se dê de forma a respeitar o justo e a capacidade contributiva, basta que o trato tributário que se oferece não seja e não possa ser individualizado ou diferenciado, em seus termos de aplicação, a partir de qualquer critério outro que não o efeito ambiental que se busca obter pela indução de uma conduta.

Fazemos essa afirmação com fundamento no que estabelece o artigo 170, VI, da CF: ao estabelecer que se dará tratamento diferenciado a determinado tipo de atividade (produtos e serviços e seus modos de produção e prestação, dado o impacto ambiental que geram), o legislador constitucional estabeleceu, como elemento diferencial entre a situação de um e de outro contribuinte, a variável ambiental traída de forma transversal à relação 
entre esse contribuinte e o Estado, tomadas as características da atividade que desempenha e os efeitos de classificação (regime e tratamento) tributário que recebe a partir daí.

O elemento diferencial deve ser sempre, portanto, a condição ambiental que estará a diferenciar um contribuinte de outro. Assim se comportando a mecânica proposta, não se estará ofendendo o princípio da capacidade contributiva como elemento determinante do regime e tratamento tributário aplicado aos contribuintes.

\section{(5) as espécies de tributo e a adequação à conjugação das competências ambientais e fiscais}

Para que se possa apresentar a proposta final deste trabalho, de abordagem das políticas públicas florestal e de energia a partir da visão transversal que lhes deve ter a Política Nacional sobre Mudança do Clima (6º, VI, da Lei nº 12.187/2009), indicando-se os mecanismos tributários que se considera adequados à implementação do que se propõe seja a intervenção qualitativa do Estado sobre a economia, sob o enfoque da sustentabilidade, faz-se necessário tratar, preliminarmente, das espécies de tributos previstas em nosso sistema, e o papel de cada uma delas diante da possibilidade de seu uso para fins de ordem ambiental. Parte-se, pois, para tal exercício.

Queremos entender livre de dúvidas que o conceito de tributo abarca não apenas os impostos, as taxas e as contribuições de melhoria, que são as categorias nas quais se inserem também as espécies de tributos outras, quais sejam, os empréstimos compulsórios e as contribuições especiais (contribuições parafiscais, impostos extraordinários e contribuições postas no artigo 149 da CF), que são tributos ainda que não mencionados nos incisos I a III do artigo 145 da Constituição Federal.

Fundamos nosso entendimento na doutrina e jurisprudência, e lançamos mão aqui, a título de exemplo, dos ensinamentos do Professor Aliomar Baleeiro ${ }^{117}$, que defende o entendimento que aqui declinamos.

Nos ensinamentos do Professor Roque Antonio Carrazza ${ }^{118}$ buscamos a classificação jurídica dos tributos, que os separa em três categorias, nas quais se inserem as espécies outras:

\footnotetext{
${ }^{117}$ BALEEIRO, Aliomar. Direito tributário brasileiro. Atualizada por Misabel Abreu Machado Derzi. 11. ed. Rio de Janeiro: Forense, Rio de Janeiro, 1997. p. 63.

${ }^{118}$ CARRAZZA, Roque Antonio. Curso de direito constitucional tributário. 24. ed. São Paulo: Malheiros Ed., 2008. p. 511-629.
} 
(i) Imposto - trata-se de tributo não vinculado (sua hipótese de incidência é um fato qualquer, não consistente numa atuação estatal), orientado pelo princípio da capacidade contributiva. Não se prende a uma atuação do Estado, para a qual se busca contrapartida. Surge da condição legitimada do Estado em estabelecê-lo.

(ii) $\underline{\text { Taxa }}$ - a definição de taxa não é consenso na doutrina. Trata-se de obrigação ex lege que nasce da realização de uma atividade estatal relacionada de modo específico ao contribuinte. Difere do imposto, portanto, pela vinculação a uma atividade do Estado que lhe dá origem, ainda que tal atividade não tenha sido requerida pelo contribuinte.

(iii) Contribuição de melhoria - a contribuição de melhoria é uma espécie de tributo que tem por hipótese de incidência uma atuação do Estado indiretamente referida ao contribuinte. Essa atuação, por força de disposição constitucional (artigo 145, III), deve necessariamente ser uma obra pública que, por via reflexa, afeta positivamente o patrimônio do contribuinte.

(iv) Empréstimos compulsórios - tributo restituível, conforme o denominou João Mangabeira, vinculado a hipóteses constitucionais específicas (artigo 148, I e II da CF).

(v) Contribuicões especiais (ou parafiscais) - são tributos que podem revestirse da natureza jurídica de imposto, taxa ou contribuição de melhoria, e que têm como característica o fato de serem instituídos pelo legitimado mas cobrados por um terceiro.

(vi) Impostos extraordinários - trata-se, diz o conceito, de impostos, vinculados apenas a uma condição fática específica, na forma do que estabelece o artigo 154, II, da $\mathrm{CF}$, por essa razão e somente por essa razão diferindo do imposto indicado no item “i” acima. Não se tem, portanto, aqui uma subespécie, ou um tributo sui generis. Trata-se tão somente de um imposto com condição fática peculiar.

(vii) Contribuições — são tributos, conforme já decidiu o STF (RE 146.733-9, Pleno, julgado em 26.6.1992), qualificados pela finalidade que devem alcançar. Tomadas hipótese de incidência e bases de cálculo, poderão configurar-se como imposto ou taxa. Três são as modalidades de contribuições: as sociais, as interventivas e as corporativas. 
A nosso ver, qualquer que seja a escolha da espécie tributária eleita, o fundamental é que seja informado, seu uso, pelo princípio da sustentabilidade, e não pela simples internalização de custos ambientais, orientada pelo princípio do poluidor-pagador. Não queremos com tal afirmação negar a validade ou defender que se abandone o uso de tributos para este fim último. Compreendemos a internalização de custos ambientais, fundada no princípio do poluidor-pagador, como um instrumento fundamental e indispensável à composição do sistema, porquanto indispensável à completude da ferramenta do comando e controle. Tal ferramenta, já se esclareceu aqui, não é conflitante com a adoção do mecanismo que propomos, de trato da interação entre proteção ambiental e atividade produtiva vista a partir de uma abordagem mais ampla, de integração de políticas públicas a partir da variável ambiental. Se, por meio da internalização de custos, se implementa o comando e controle, que trata de uma visão pontual da interação entre produção e meio ambiente, o mecanismo que propomos tratará, como dito, da interação entre políticas públicas, deixando de lado o pontual. Daí não vermos conflito, mas sim sinergia, complementariedade entre um e outro mecanismo.

Conforme defendem Lidia Maria L.R. Ribas e Valbério Nobre de Carvalho ${ }^{119}$, $o$ tributo denominado ambiental, de forma ampla, é todo aquele voltado para a defesa do meio ambiente. Pode ser um imposto, uma taxa ou uma contribuição de melhoria. Pode, ainda, ser um novo tributo ou um tributo já existente, mas cuja forma de tributação tutela o meio ambiente.

O mecanismo da internalização de custos ambientais parece encontrar sua materialização adequada na figura das taxas (em exercício fiscal, e não extrafiscal), dada a natureza de causa e efeito que esta espécie de tributo chama para si: o elemento definidor fato gerador - da incidência da taxa será a caracterização do empreendimento como gerador de externalidades negativas não neutralizadas ou reduzidas a valores aceitáveis, absorvíveis pela sociedade. A taxa ambiental poderá ser aplicada como forma de internalização pura dos custos ambientais - as externalidades - gerados pela atividade sob controle estatal, ou ainda como elemento de custeio da estrutura de fiscalização de atividades havidas como geradoras de tais externalidades negativas.

\footnotetext{
${ }^{119}$ RIBAS, Lídia Maria L. R; CARVALHO, Valbério Nobre de. O tributo como instrumento de tutela do meio ambiente. Revista de Direito Ambiental, São Paulo, v. 14, n. 54, p. 188, abr./jun. 2009.
} 
Exemplo maior deste último caso, a nosso ver, é a Taxa de Controle de Fiscalização Ambiental - TCFA, criada pela Lei $\mathrm{n}^{\circ}$. 10.165, de 27.12.2000, e que se presta a custear as atividades de fiscalização ambiental realizada pelo Instituto Brasileiro do Meio Ambiente e dos Recursos Naturais Renováveis - IBAMA. Exemplo clássico de uso de tributo inspirado no princípio do poluidor-pagador, a TCFA presta-se a financiar a atividade do Estado no exercício do comando e controle.

Necessário destacar aqui em breves parênteses a lição de Nabais ${ }^{120}$, que afirma serem os impostos o melhor caminho para consecução dessa internalização de custos, valendo-se do argumento de que, enquadrados no "estado fiscal", os tributos de ordem ambiental não podem afastar-se da "solução financeira consubstanciada no estado fiscal, deslocando o suporte financeiro de tais tarefas [tarefas ambientais pela via tributária] para a solução proporcionada pelo 'estado taxador'”.

O raciocínio do respeitado doutrinador português, fundado no princípio do poluidor-pagador, enxerga a tributação ambiental, nas palavras do próprio, como elemento de implementação do princípio do poluidor-pagador, inserido no contexto da Comunidade Europeia, como elemento de orientação de políticas fiscais, por meio do Tratado que a instituiu, artigo 174, n. 2.

No entanto, a realidade brasileira demonstrou ser possível realizar-se a implementação de tal princípio, por meio da internalização de custos ambientais, pelo uso das taxas, conforme se destacou acima, ao se invocar o uso da TCFA para a internalização do custo referente à máquina estatal necessária ao exercício do comando e controle vinculado exatamente ao princípio do poluidor-pagador (e da prevenção). Quando vemos a existência da citada TCFA, vemos que a implementação do princípio do poluidor-pagador, no Brasil, incluiu o custeio, por meio de tributação, da atividade de controle vinculada, usando-se para tanto a taxa como espécie tributária eleita.

De toda forma, a limitação defendida pelo renomado doutrinador não infirma a tese que defendemos porquanto partimos, em nossa proposta, de um princípio diverso adicional, e não excludente - como vetor de orientação da implementação da intervenção do Estado na economia, por meio de políticas tributárias. Elegemos como fundamento para nossa proposta o princípio da sustentabilidade, que impõe o abandono da postura pontual

\footnotetext{
${ }^{120}$ NABAIS, José Casalta. Tributos com fins ambientais. Revista Tributária e de Finanças Públicas, São Paulo, ano 16, v. 80, p. 253-280, maio/jun. 2008.
} 
de controle da atividade poluidora. Assim, nessa nova abordagem, poder-se-á lançar mão de qualquer das espécies tributárias, desde que o resultado, sempre, seja o de induzir as espécies de atividades, dentro de um setor da economia, que se revelem mais próximas da conduta sustentável (sob o prisma que se estiver ali adotando como política de sustentabilidade/ambiental que se usa de forma transversa à atividade produtiva). Ou, de forma simplificada, observado o princípio da sustentabilidade como norte, qualquer das espécies de tributo será bem-vinda.

Deixe-se os parênteses de lado, e volte-se ao exame das espécies tributárias. Em evolução ao uso de tributos vinculados ao princípio do poluidor-pagador, taxas ambientais são também utilizadas como instrumento de materialização do princípio do usuáriopagador. Exemplo clássico é a cobrança de taxa pelo uso da água, prevista pela Lei $\mathrm{n}^{\circ}$. 9.433, de 8.1.1997 (artigos 5º, IV, e 19 a 22).

Esses exemplos de uso do tributo como elemento de internalização de custos ambientais têm em comum a abordagem pontual, individualizada, da atividade produtiva diante do risco ambiental.

Tal abordagem é importante, porque se presta a impor ao exercício da atividade poluidora o custo que gera ao meio ambiente. Mas, a nosso ver, incompleta, porque não tem o condão de gerar efeitos derivados positivos, na medida em que (i) atua de forma meramente reativa, sem gerar como resultado a redução do risco e do custo ambiental, que são tão somente absorvidos; e (ii) não tem efeito multiplicador positivo, já que atua sobre a atividade específica, e não sobre um ramo específico da atividade produtiva.

E como se daria, no âmbito da abordagem que propomos, o uso dos tributos como elemento que não atue de maneira meramente reativa, mas sim de forma indutora, e com efeito multiplicador positivo? Queremos crer que a resposta está na percepção da integração entre a proteção ambiental e o exercício de atividades econômicas segundo uma transversal interferência de políticas públicas de cunho ambiental, por força da qual se afeta, na raiz da atividade produtiva (e não como uma reação a seus efeitos), a composição de seus custos, por força da alteração da relação de carga tributária realizada não a partir de uma visão unitária, individualizada da interação empreendimento $X$ meio que o recebe, mas a partir da inserção e classificação da atividade que se aborda dada sua tipologia no âmbito de um ramo de negócio, de um setor de produção, vistas as outras alternativas, e definida a comparação pela força transversal que se aplica. 
Neste cenário, identificada a variável transversal - ou seja, a política pública de perfil ambiental que se adotou como fator de indução do exame - sob a qual se examinará o setor da economia escolhido, a definição dos tributos sob os quais se atuará, para se criar o resultado proposto, passará, em um primeiro momento, pela identificação dos tributos cuja aplicação se realiza na mesma esfera da variável transversal de que se cogita. O que se diz aqui é o óbvio, mas não é demais destacar. Em termos práticos, no exame de um determinado setor da economia, ao qual se busca dar ferramentas de busca de sustentabilidade, por meio do trato tributário diferenciado a que se refere o artigo 170, VI, da $\mathrm{CF}$, deve o intérprete apegar-se à análise dos tributos de mesma esfera da política pública de perfil ambiental que se quer prestigiar. A competência para instituir tributos, pois, será fundamental para encontrar o resultado buscado e estabelecer ferramentas.

Vale invocar um exemplo prático recente, de que se lança mão aqui à guisa de ilustração: na forma da Lei $\mathrm{n}^{\circ}$. 12.375, de 30.12.2010 (artigo $5^{\circ}$ ), regulamentada pelo Decreto $\mathrm{n}^{\circ}$. 7.619, de 21.11.2011, fazem jus a crédito presumido do Imposto sobre Produto Industrializados - IPI, até 31 de dezembro de 2014, os estabelecimentos industriais que adquirirem resíduos sólidos - tipos de resíduos definidos pelo Decreto - de cooperativas de catadores, para uso como matéria-prima ou produtos intermediários.

A criação de tal mecanismo tem por finalidade induzir o setor industrial a adotar comportamento que tende à sustentabilidade, uma vez que vinculado aos objetivos da Política Nacional de Resíduos Sólidos (Lei nº 12.305, de 2.8.2010), quais sejam, o trato dos resíduos sólidos de forma a que sejam reinseridos na cadeia de produção econômica, reduzindo-se o volume de rejeitos (a Lei nº. 12.305 assim denomina os resíduos que, já não passíveis de aproveitamento e reinserção no ciclo produtivo, devem ter disposição adequada), gerando-se valor econômico aos resíduos, e garantindo-se inclusão social (pretendida e estimulada pela Lei $\mathrm{n}^{\mathrm{o}}$. 12.305 pela inserção dos catadores de papel como agentes da coleta de resíduos sólidos voltada à sua reinserção na cadeia produtiva).

Vale dizer, o mecanismo de ordem tributária estabelecido pela Lei $\mathrm{n}^{\circ}$. 12.375 presta-se ao propósito da implementação do princípio da sustentabilidade, pela aplicação transversal da Política Nacional de Resíduos Sólidos à atividade industrial, que é induzida ao comportamento sustentável pela concessão do benefício fiscal.

Um ponto que não se pode perder de vista, no exercício da indução à sustentabilidade por meio do manejo das ferramentas tributárias, é o de que não pode o 
Estado afastar-se, em nenhum momento, da busca pelo "justo". O exemplo que se vem de citar, nesse aspecto, não poderia ser mais feliz, uma vez que, no trato da questão de ordem ambiental - a gestão sustentável dos resíduos sólidos, pela sua reinserção na cadeia produtiva - de que se ocupa, a Lei $\mathrm{n}^{\mathrm{o}}$. 12.305 abrangeu o benefício de ordem social, propiciando a viabilização da reinserção no mercado formal de trabalho de um grupo de cidadãos, os catadores de resíduos, cuja atividade, em regra desenvolvida em caráter informal, é marginalizada pela sociedade. O justo, aqui, revela-se diretamente vinculado ao benefício fiscal concedido.

Assim, respeitada sempre a competência para criar e tratar do tributo, observadas as regras constitucionais a tanto, poderá o Estado disciplinar a aplicação de tributos a determinadas atividades econômicas, induzindo assim condutas, de acordo com o interesse da sustentabilidade informado pela política pública que, de forma transversal incide sobre tais atividades econômicas.

\section{(6) O caso da Política Nacional sobre Mudança do Clima - tributos e as espécies adequadas - a proposta}

Procurou-se demonstrar, neste trabalho, ter-se esgotado o modelo de comando e controle, e da orientação do uso dos tributos como ferramenta de suporte às políticas públicas de meio ambiente, pela vertente do princípio do poluidor-pagador. Buscou-se ainda demonstrar que, na forma do permissivo constitucional do artigo 170, VI, impõe-se a adoção de abordagem nova, orientada pelo princípio da sustentabilidade, em razão da qual o uso dos mecanismos tributários deve passar da incidência pontual à consideração não mais de atividades, isoladamente, mas de setores da economia, de forma geral, para orientá-los e induzilos a uma conduta ambientalmente adequada. A transversalidade de políticas públicas de ordem ambiental em relação às políticas públicas outras é que deve ser, conforme defendemos, o mote de aplicação do ferramental tributário visando à indução de posturas sustentáveis.

Nesse contexto é que, aqui, tomamos os setores eleitos para estudo, quais sejam, o de energia e o de florestas, para que, tomando a transversalidade que sobre eles carrega a Política Nacional sobre Mudança do Clima, verificarmos quais os instrumentos tributários que podem ser usados - e de que maneira - para induzir posturas sustentáveis aos agentes que operam em tais setores. 
A política pública que entendemos transversal às políticas florestal e de energia, conforme já anunciado, é a Política Nacional sobre Mudança do Clima.

No que toca à política florestal, o tema é central ao sucesso da Política Nacional sobre Mudança do Clima, uma vez que, já se disse neste trabalho, (i) nossa maior fonte de emissão de GEE reside no desmatamento e na degradação da floresta (queimadas, primordialmente); (ii) a Política Nacional sobre Mudança do Clima trata da redução das emissões de GEE decorrentes do desmatamento e degradação da floresta como um de seus objetivos centrais (Lei $\mathrm{n}^{\circ}$. 12.187/2009); e (iii) no atual estágio, percebe-se ineficácia dos instrumentos legais estabelecidos para preservação florestal.

O mesmo se pode dizer da nossa política energética: a Política Nacional sobre Mudança do Clima lhe é transversal porquanto (i) as emissões de GEE geradas pelo setor de energia é um dos temas abrangidos pela Política Nacional sobre Mudança do Clima, na medida em que expressamente estabelece a necessidade de estímulo ao desenvolvimento das fontes alternativas - renováveis - em nosso parque gerador; e (ii) o quadro atual mostra ampliação da participação de fontes não renováveis na composição da matriz de nosso parque gerador.

Assim, entendemos ser livre de dúvida que a implementação da Política Nacional sobre Mudança do Clima, e a sua eficácia mesmo, passa pela integração entre tal instrumento e as políticas florestal e de energia, incidindo a Política Nacional sobre Mudança do Clima de forma transversal, e, portanto, influindo na dinâmica das políticas de energia e florestal.

Vem bem a propósito a lição de Maria da Glória Garcia ${ }^{121}$, para quem

\begin{abstract}
"A sustentabilidade ambiental envolve a interrogação sobre a conexão entre o desenvolvimento económico e consequentes custos marginais, nunca integralmente absorvidos pela geração que consome os produtos que lhes dão origem, e a preservação da qualidade ambiental, aferida pelos ciclos de vida que sustenta e pelos recursos de que a Terra dispõe, nomeadamente energéticos. A sustentabilidade ambiental reside aqui, na resposta que se der a esta interrogação. É uma questão aberta, que se renova com o acréscimo de conhecimentos sobre o comportamento ambiental e se renova, ainda, com o esgotamento e escassez dos bens que o compõem, nomeadamente com a perda da biodiversidade." (os negritos são nossos)
\end{abstract}

\footnotetext{
${ }^{121}$ GARCIA, Maria da Glória F. p.D. O lugar do direito na protecção do ambiente. Coimbra: Almedina, 2007. p. 172.
} 
Veja-se que a respeitada autora vincula a sustentabilidade ao trato adequado de duas variáveis componentes do meio ambiente: os recursos energéticos, de um lado, e a biodiversidade, de outro. Esse raciocínio justifica a escolha que fizemos, no que toca às políticas públicas - energética e florestal - a serem consideradas para exame da intervenção transversal pela Política Nacional sobre Mudança do Clima.

E nossa proposta, para a forma de efetivação dessa transversalidade, vai como segue:

\section{(6.a) A integração, pela transversalidade, entre a Política Nacional sobre Mudança do Clima e a política energética}

No exercício da aplicação de nossa política energética, demonstrou-se acima, neste trabalho, que o sistema de contratação de energia nova se rege por duas variáveis: preço, na modalidade livre, e tarifa, na modalidade vinculada. Assim, o resultado prático, para efeitos de consideração da variável ambiental, é de que se nivelam os projetos pelo conceito da legalidade: havendo o licenciamento ambiental, todos os empreendimentos, seja qual for a matriz energética adotada, competem em iguais condições, já que o critério diferenciador da contratação é, como dito, o preço/tarifa.

E nem poderia ser diferente, já que, para que se observe o "justo" - igualmente já declinado e explicado acima - na contratação de energia, deve-se onerar o mínimo possível o contribuinte, que arcará com o preço/tarifa da energia contratada.

Como, então inserir, de maneira transversal, a variável climática?

Queremos entender que o objetivo dessa inserção transversal, tomado o princípio da sustentabilidade, e visto o sistema de forma geral, e não meramente pontual, deve ter por objetivo alterar a composição de nosso parque gerador, de forma a induzir a uma maior participação das fontes alternativas entre nossas matrizes de geração de energia.

Daí por que entendemos que, sem se alterar a forma de contratação de energia preço/tarifa - vigente, deve-se inserir a aplicação de uma Contribuição de Intervenção no Domínio Econômico - CIDE $^{122}$ na composição do custo da energia a ser provida, de forma

\footnotetext{
${ }^{122}$ Heleno Taveira Tôrres destaca, ao tratar da CIDE - combustíveis, que tal ferramenta "promove adequado tratamento à questão ambiental, efetivando o compromisso constitucional de desenvolvimento sustentável
} 
transversal, ou seja, incidente sobre todas as diferentes matrizes de energia, determinandose a base de cálculo do valor de incidência dessa CIDE a partir da consideração do volume ponderado de emissão de GEE para cada uma dessas matrizes de energia.

Assim, a partir de inventário que indique a emissão média de GEE para cada matriz de energia, considerada como unidade de medida a relação $\mathrm{tCO}_{2 \mathrm{eq}} / \mathrm{Kw}$ de energia, poderse-á definir o valor da CIDE a ser desembolsada para equalização, a partir da via transversal da mudança do clima, dos empreendimentos de geração de energia elétrica a partir da matriz adotada. Quanto maior o volume de GEE emitido, medido em relação ao volume de $\mathrm{Kw}$ gerados, maior o valor a ser desembolsado pelo empreendimento.

Paralelamente, ainda sob a transversal interferência da política climática sobre a política energética, a implementação do princípio da sustentabilidade, por meio de mecanismos tributários, imporia a consideração da carga tributária incidente sobre a composição do preço/tarifa para cada uma das matrizes, de forma a se desonerar as matrizes renováveis, considerados, como fator de ampliação da desoneração, ou redução de seus efeitos, (i) a cadeia de produção; e (ii) o grau de nacionalização dos equipamentos utilizados.

A carga tributária incidente sobre a produção de energia para fontes alternativas, como, por exemplo, a eólica, é substancialmente maior do que a carga de tributos incidente sobre a energia de origem térmica. Assim, tomado o perfil da matriz, verifica-se um contrassenso, pois, ao tempo em que se estimula, pela Política Nacional sobre Mudança do Clima, a geração de energia por fontes alternativas, o próprio Estado cuida de desestimular o investimento em tais matrizes, dada a pesada carga de tributos incidente.

A solução, aqui, é reduzir a carga tributária aplicável às fontes renováveis de energia, desde que preenchidos os critérios de (i) cadeia de produção sustentável; e (ii) índice de nacionalização dos equipamentos utilizados.

A adoção do critério da cadeia de produção dos equipamentos utilizados justifica-se porquanto somente fará sentido o estímulo proposto desde que os equipamentos cuja aquisição se propõe desonerar tenham sua produção realizada de acordo com o princípio da sustentabilidade, informador do benefício ofertado.

\footnotetext{
sem qualquer prejuízo às garantias constitucionais em matéria tributária” (TÔRRES, Heleno Taveira. A proteção a áreas degradadas por atividades relacionadas à indústria do petróleo e do gás e seus derivados e o emprego da CIDE-Combustíveis. In: SCAFF, Fernando Facury; ATHIAS, Jorge Alex (Coords.). Direito tributário e econômico aplicado ao meio ambiente e à mineração. São Paulo: Quartier Latin, 2009).
} 
Já no que toca à desoneração de acordo com o índice de nacionalização dos equipamentos utilizados para a geração de energia a partir de fontes alternativas, justificase a proposta porquanto necessário estimular a economia local, não se justificando, para sanar a questão das emissões de GEE, lançar mão de equipamentos produzidos no exterior com redução da carga tributária incidente, já que tal medida tenderia a deprimir a capacidade de desenvolvimento de tecnologias e produção de equipamentos internamente.

Entendemos que, adotada essa estrutura, seria possível inserir, na política energética, a variável climática, reorientando-se, ao menos parcialmente, o investimento na geração de energia no Brasil.

Voltemos à CIDE proposta. O fundamento de sua cobrança seria a necessidade de dar cumprimento à Política Nacional sobre Mudança do Clima. Assim, a destinação dos recursos arrecadados deve guardar necessário vínculo com tal mister, sob pena de ofenderse o mote de criação da CIDE, em irregularidade inaceitável. Esse o entendimento esposado pelo Tribunal de Contas da União, por ocasião de exame da aplicação inadequada de recursos da CIDE - Combustíveis (estabelecida pelo artigo 177, $\S 4^{\circ}$, da $\mathrm{CF}$, por força da EC 33/2001) nos anos de 2002 a 2005 (Acórdão 1.857/05):

(...) 6. Não posso concordar, desse modo, com o constante emprego de recursos da Cide-Combustíveis em gastos estranhos aos propósitos definidos constitucionalmente. Nem mesmo com o custeio de despesas de caráter administrativo, em que pese o esforço demonstrado pelos Ministérios requeridos para convencer da adequação dessa prática, sob o argumento de que aquelas deveriam compor os custos dos programas de infra-estrutura de transportes.

7. Ora, a natureza interventiva, nobre e excepcional da contribuição não comporta utilização que não a dignifique. Não há qualquer merecimento numa tributação especial que se preste a proporcionar auxílioalimentação, como se evidencia. Certamente, os cidadãos não foram sobretaxados, de forma tão incomum, para colaborar com a manutenção da máquina administrativa. Se este fosse um dos objetivos da contribuição, não me parece que o legislador constituinte a aprovaria.

Na mesma esteira, o Supremo Tribunal Federal já havia julgado inconstitucional, no ano de $2003^{123}$, a abertura de crédito suplementar por lei orçamentária em rubrica estranha à destinação do que arrecadado a partir do disposto no $\S 4^{\circ}$ do artigo 177 da Constituição Federal.

\footnotetext{
${ }^{123}$ Ação Direta de Inconstitucionalidade 2.925-8.
} 
(6.b) A integração, pela transversalidade, entre a Política Nacional sobre Mudança do Clima e a política florestal

Diante da necessidade de destinação da CIDE, conforme se vê da jurisprudência atinente à CIDE - Combustíveis, aos propósitos de seu estabelecimento, e tendo em conta que o propósito de estabelecimento da "CIDE - Clima" - conforme entendemos deva ser denominada a proposta que fazemos - é o atendimento aos objetivos da Política Nacional sobre Mudança do Clima, entendemos que a destinação dos recursos oriundos da CIDE Clima deve se dar a projetos que visem a contribuir para a redução de nossas emissões de GEE. Assim, mantém-se coerência entre a base de cálculo da incidência da CIDE - Clima sobre o setor de energia e a destinação dos recursos auferidos e, ao mesmo tempo, obtém-se otimização de seus efeitos, com sua aplicação no mesmo ambiente em que gerada - a questão climática.

E, tratando-se de aplicar tais recursos em projetos que visem à redução de nossas emissões de GEE, não há escolha melhor do que destinar tais recursos a projetos de REDD+. Isso porque, conforme já demonstrado neste trabalho, (i) projetos de REDD+ incidem sobre o setor - florestal - em que vemos nossa maior fonte de emissão de GEE (desmatamento e queimadas, com a degradação da floresta); (ii) a carência de recursos materiais para custeio da proteção, conservação e monitoramento dos espaços territoriais afetados à condição de UCs é notória; e (iii) adotando-se tal postura, inverte-se a lógica pela qual as UCs constituem custo puro ao Estado, para se amenizar esse peso, já que, da venda dos créditos gerados pelos projetos de REDD+, advirá receita a partir do espaço territorial afetado à UC.

A proposta, portanto, é simples em sua visualização: propõe-se a criação de uma CIDE, a CIDE - Clima, incidente sobre os empreendimentos de geração de energia, no setor elétrico, adotando-se como base de cálculo da contribuição o volume médio de emissão de GEE gerado pelas diferentes matrizes energéticas, por Kw. Os recursos obtidos a partir dessa CIDE - Clima revertem necessariamente para o financiamento de projetos de REDD+ nas UCs, de forma a que se inverta a lógica de custo puro dessas áreas para o Estado.

A proposta formulada, no entanto, não soluciona um ponto crítico do setor florestal, declinado no capítulo próprio deste trabalho: Reserva Legal e APP, para as quais igualmente se tem déficit de cumprimento da lei, e em relação às quais igualmente se vê 
problema crônico: a afetação de áreas privadas rurais a tal ônus torna-a um custo para o proprietário rural, que não pode aproveitá-las em seus negócios.

Para solucionar tal questão, parte dos recursos obtidos a partir da cobrança da CIDE - Clima poderá - e entendemos que deverá - ser direcionada ao financiamento de projetos de REDD+ no território brasileiro. Entendemos, aqui, que apenas projetos pré-selecionados pelo Ministério de Ciência e Tecnologia, por meio da Comissão Interministerial de Mudança Global do Clima, poderiam ser beneficiados pelo recebimento de custeio pela CIDE - Clima.

Defendemos o entendimento e, adotada essa estrutura, estará a proposta formulada livre de críticas no que toca à configuração de tributo de ordem ambiental. Lançamos mão aqui do ensinamento de Heleno Taveira Tôrres ${ }^{124}$, que permeou a estruturação da proposta aqui formulada, para sustentar que, qualquer que seja a abordagem que se faça da estrutura apresentada, verificar-se-á o mote de atendimento ao princípio ambiental [a sustentabilidade como objetivo] que a sustenta, preservando-a portanto de críticas.

Com efeito. A origem, o motivo constitucional informador da proposta é o princípio da sustentabilidade, inserto no artigo 225, caput, da Constituição Federal, combinado com a faculdade - dever - atribuída ao Estado pelo artigo 170, VI, do texto Maior. A estrutura do tributo bem demonstra estarmos no campo ambiental: a base de cálculo proposta para a determinação de sua alíquota é estritamente de ordem ambiental (o volume de emissões ponderado de GEE para cada uma das matrizes de geração de energia elétrica disponíveis em nosso país), e a destinação dos fundos arrecadados também observa esse perfil, já que viabilizarão projetos de REDD+ em UCs e áreas afetadas pelos institutos da Reserva Legal e da APP.

Bem se vê, origem, estrutura, finalidade e destinação do tributo proposto vinculamse ao objetivo ambiental.

\footnotetext{
${ }^{124}$ TÔRRES, Heleno Taveira. Da relação entre competências constitucionais tributária e ambiental - os limites dos chamados "tributos ambientais", cit., p. 100-101.
} 


\section{CONCLUSÃO}

Ao longo da História, civilizações e sociedades avançadas sucumbiram diante de fatores variados, sempre encontrando, dentre eles, a influência, em maior ou menor grau, da questão climática. Mais recentemente, com a alteração do regime climático, a partir da contribuição antrópica, por meio da emissão de Gases de Efeito Estufa - GEE, a questão passou a ter efeito global, reclamando portanto debates e providências em igual escala, sem prejuízo da adoção de medidas internas, pelos vários países, como forma de contribuição individual à redução das emissões de GEE.

No Brasil, tomada a evolução de nossa consciência ambiental, e da resposta provida pelo Estado, percebe-se que o sistema eleito, fundado em larga escala no binômio comando e controle, teve por ponto orientador o princípio do poluidor-pagador, quando estabelecida a Política Nacional do Meio Ambiente, em 1981. Ainda que caminhando com o apoio de outros princípios e mecanismos (tais como o da publicidade, o da prevenção, que lhe precede, e outros), o sistema trazido de 1981 até poucos anos atrás primou pelo controle do Estado sobre a atividade econômica, para contenção do risco ambiental, adotadas ferramentas de reparação ou indenização, sempre quando ineficiência do sistema permitir a ocorrência do dano ambiental, da externalidade negativa que se quer evitar.

Demonstramos aqui que a conseqüência de tal cenário é a constatação de que o modelo de controle do risco ambiental tradicional em nosso sistema revela-se hoje saturado. Indispensável, porque estabelece a base de relacionamento entre sociedade e atividades econômicas, o sistema, no entanto, reclama complementação. Essa nossa conclusão que estabelece a necessidade de criação de novos caminhos para a abordagem da questão ambiental - e climática - em nosso sistema.

Nesse contexto é que um novo cenário deve ser desenhado, tomado por ponto de partida já não o princípio da prevenção e seu elemento de materialização, o princípio do poluidor-pagador, mas já agora uma nova abordagem, pela qual não se trate a relação entre atividade econômica e meio ambiente de maneira pontual, individualizada, mas sim sob visão geral, coletiva. 
A adoção de tal visão a partir da perspectiva da questão da mudança do clima reclama atenção às regras de cunho internacional, aqui internalizadas, das quais somos parte, assim como ao sistema interno de proteção ambiental, não à toa dito pela doutrina como um dos mais restritivos em vigência.

Assume especial importância, para que ocorra a adoção dessa nova visão, a verificação do papel que cabe ao Estado desempenhar no cenário que se busca implementar. Ao Estado espera-se que intervenha sobre a ordem econômica, fazendo-o de forma qualitativa, para que seja assim veículo de viabilização da implementação de mecanismos e instrumentos voltados a gerar resultados que nos aproximem da sustentabilidade.

Tal tarefa, no entanto, não pode ser desempenhada sob o enfoque tradicionalmente trazido ao longo das últimas décadas. Pontual, restrito, tal enfoque não permite nem busca resultados amplos, de ordem e alcance abrangentes. O risco da postura pontual, de análise e intervenção individual sobre a atividade econômica, é o de se criar um Estado pesado, excessivamente causador de peso sobre os agentes econômicos, submetendo os contribuintes a injusto peso. Outro risco é o de que, se não alterada a proposta de atuação pelo princípio do poluidor-pagador, se chegue a um Estado de ineficiência insuportável.

A vertente a ser seguida, portanto, deverá ser a de uma atuação que deixe o individual em favor do geral, difuso, fundado não mais na precificação do custo ambiental como forma de forçar a sua internalização pelo agente econômico, mas agora pela observância do "justo" como elemento indissociável da atuação do Estado, direcionada à implementação do princípio da sustentabilidade pelo uso de mecanismos de alcance difuso entre os agentes econômicos.

Para tanto, o que se vê como viável e lógico é abordagem das políticas públicas várias a partir de uma visão transversal a ser exercida pelas políticas públicas de caráter ambiental, o mesmo se verificando entre políticas de caráter ambiental, entre si.

O instrumento para que possa chegar a tal caminho parece-nos ser necessariamente o do uso dos tributos, de forma "justa", difusa, equilibrada, e coordenada, aceita a premissa de que sustentabilidade é um processo que não se desenvolve de forma pontual, isolada, individualizada, mas sim de maneira difusa, coletiva e agrupada. 
As políticas públicas que se propõe estudar, sob esse estado de pensamento, são, respectivamente, a Política Nacional sobre Mudança do Clima, dada sua clara importância, origem internacional, e influência sobre tantas outras políticas públicas em vigor. De outro lado, propõe-se o exame das políticas energética, dada sua direta relação com a questão climática e com nossas emissões de GEE, assim como a política florestal brasileira, que cuida de setor outro de relevante importância no que toca à questão climática e nossas emissões de GEE.

A realidade atual de nossas políticas energética e florestal, vistas a partir da ótica da questão climática, é desanimadora: de um lado, nosso parque gerador de energia elétrica torna-se cada vez mais dependente de matrizes ditas sujas, como as termelétricas, cujo perfil representa aumento em nossas emissões de GEE na produção de energia elétrica.

O mesmo se verifica no tocante às nossas florestas: maior fonte de emissões de GEE em nosso país, as queimadas e desmatamento repetem-se ano a ano - ainda que com períodos de queda em seu volume total.

A postura a ser adotada pelo Estado, neste sentir, entendemos deva ser indutora, para que se possa visualizar a Política Nacional sobre Mudança do Clima de maneira transversal às políticas florestal e energética.

A intervenção qualitativa do Estado sobre a ordem econômica, neste passo, dar-se-á por meio do trato tributário da questão ambiental. Isto porque, conforme concluímos neste trabalho, o novo sistema deve ter perfil diverso daquele tradicionalmente adotado. Deixado o comando e controle, e abordada a questão sob o signo da sustentabilidade, o caminho a seguir, conforme concluímos, é o da adoção de mecanismos tributários que, aplicados sob visão adequada, permitirão o trato difuso, e não mais pontual, individualizado, da questão das emissões de GEE pelos empreendimentos do setor energético.

Aplica-se, aqui, a transversalidade que propomos: considerados os objetivos da Política Nacional sobre Mudança do Clima, e tendo-se em conta que o setor energético vem sofrendo alteração no perfil da matriz de geração de energia no Brasil, avançando a energia produzida a partir das chamadas fontes "sujas", a intervenção qualitativa do Estado sobre a atividade econômica de tal setor, visando à criação de um ambiente justo, no qual os agentes econômicos sejam estimulados a agir de forma sustentável (ou, na verdade, de forma tendente à sustentabilidade), materializa-se por meio da criação de tributos que induzam o mercado a investir nas ditas fontes limpas de energia. 
O mesmo se pode dizer de nossas políticas florestais. Historicamente fundadas em mecanismos de criação de espaços protegidos, que trazem consigo os efeitos colaterais de restringirem a atividade econômica nas áreas que afetam, transformando em custo para o agente econômico a manutenção de tais áreas (quando protegidas por meio de institutos como a Reserva Legal e a APP), tais políticas, vistas sob a transversalidade da Política Nacional sobre Mudança do Clima, reclamam novos instrumentos, que venham não mais a restringir e deprimir a atividade econômica, mas sim que venham a aliviar este peso, sem que se descure do objetivo de trazer novos mecanismos e instrumentos que permitam viabilizar o atendimento às várias políticas públicas examinadas, e não modificá-las. A transversalidade não dispensa o atendimento às normas trazidas pelas políticas públicas que se vêem atingidas pelo elemento transversal.

O veículo, o instrumento que entendemos adequado à materialização desse mister, demonstramos aqui, é a CIDE, de forma a que se possa, por meio dela, estabelecer uma intervenção de ordem qualitativa e indutora do Estado sobre a política energética, visto que a incidência que se propõe para o tributo defendido define-se pelo teor de emissão de GEE das diferentes potenciais matrizes (fontes) de energia disponíveis. $\mathrm{O}$ efeito que se pretende, pela aplicação de tal mecanismo, é o de se estimular e induzir o capital a interessar-se mais e mais pelo investimento em empreendimentos de geração de energia alimentados por fontes renováveis de energia, reduzindo-se assim, por conseqüência, o aumento das emissões de GEE causadas pelo setor energético. A transversalidade é clara: o tributo gera alteração do perfil do parque gerador, com o controle mais adequado, e geral, não mais pontual, de nossas fontes de emissão de GEE no âmbito de tal setor da economia.

A necessidade de aplicação dos recursos obtidos por tal mecanismo em atividades de mesmo perfil é tema já decidido pelas nossas autoridades. Assim, os recursos arrecadados pela aplicação da CIDE- Clima, como a denominamos, sobre o setor energético, devem ter aplicação em atividades de mesmo fim, ou seja, vinculados à nossa Política Nacional sobre Mudança do Clima.

A proposta que trazemos é a de se aplicar tais recursos na viabilização de projetos de REDD+ e PSA nas nossas florestas, especialmente na Floresta Amazônica, dado que (i) se permitirá, assim, inversão da lógica perversa sob a qual, pela abordagem do produtor rural, a APP e a Reserva Legal constituem custo e restrição à liberdade de empreender; e (ii) poder-se-á viabilizar o hoje insuficiente custeio da manutenção e regularização de Unidades de Conservação. 
O resultado que se obtém, assim, é o de uma intervenção transversal da questão do clima sobre as políticas energética e florestal, com atuação indutora e de estímulo, do Estado, a atividades econômicas de perfil voltado à sustentabilidade (a indução ao uso de matrizes de menor geração de emissões de GEE, no setor energético), com a viabilização ainda de atividades de tal perfil pelo próprio Estado (o custeio de projetos de REDD+ e PSA utilizando os recursos da CIDE-clima), cujo efeito será ainda novo resultado positivo para a questão do combate à mudança do clima (redução das emissões de GEE pela redução do desmatamento e degradação das áreas beneficiadas pela implementação dos projetos de REDD+ e PSA). Cria-se um ciclo virtuoso, vinculado à busca da sustentabilidade. 


\section{REFERÊNCIAS BIBLIOGRÁFICAS}

ALARCÓN GARCÍA, Gloria. La fiscalidad ambiental: el fenómeno tributario y su relación com el medio ambiente. In: GIMÉNEZ, Teresa Vicente (Coord.). Justicia ecológica y protección del medio ambiente. Madrid: Ed. Trotta, 2002.

ALTAMIRANO, Alejandro. La tributacion como instrumento aplicado al mejoramiento del medio ambiente. Eco tributación. In: JORNADAS DE FINANZAS PUBLICAS, 27. Anales... Cordoba: Faculdad de Ciencias Economicas, Universidad Nacional de Cordoba, 1994.

AMARAL, Paulo Henrique do. Tributação ambiental: contributo à política de desenvolvimento sustentável no Brasil. Revista de Direito Ambiental, São Paulo, v.13, n. 50, p. 212-234, abr./jun. 2008.

AMARO, Luciano. Direito tributário brasileiro. São Paulo: Saraiva, 1997.

ANTUNES, Paulo de Bessa. Dano ambiental: uma abordagem conceitual. Rio de Janeiro: Lúmen Júris, 2002.

Direito ambiental. 7. ed. Rio de Janeiro: Lúmen Júris, 2004.

ARAGÃO, Maria Alexandra de Sousa. O principio do poluidor pagador. Coimbra: Universidade de Coimbra; Coimbra Ed., 1997.

ARAÚJO, Cláudia Campos de; FERREIRA, Maria Isabel Reis; RODRIGUES, Patricia Castilho; SANTOS, Simone Marques dos. Meio ambiente e sistema tributário: novas perspectivas. São Paulo: SENAC, 2003.

ARAÚJO, Suely Mara Vaz Guimarães de. A taxa de fiscalização ambiental e a Lei 9.960/00. Revista de Direito Ambiental, São Paulo, v. 5, n. 19, p. 82-89, jul./set. 2000.

ARNDT, Wolfgang; FISCHER, Kristian. Umweltrecht. In: STEINER (Hrsg.). Besonderes Verwaltungsrecht. 8. Aufl. Heidelberg, 2006. S. 813-923.

ATIENZA, Manuel. As razões do direito: teorias da argumentação jurídica. São Paulo: Landy, 2000.

AULETE, Caldas. Dicionário contemporâneo da língua portuguesa. Rio de Janeiro: Delta, 1958.

AZEVEDO, Pedro Ubiratan E. Eficácia das normas constitucionais sobre o meio ambiente. In:CONGRESSO DE PROCURADORES DO ESTADO DE FORTALEZA, 20. São Paulo: Centro de Estudos da Procuradoria Geral do Estado de São Paulo, 1994. p. 87-97. 
BACHELET, Michel. A ingerência ecológica: direito ambiental em questão. Lisboa: Instituto Piaget, 1995.

BALEEIRO, Aliomar. Direito tributário brasileiro. Atualizada por Misabel Abreu Machado Derzi. 11. ed. Rio de Janeiro: Forense, Rio de Janeiro, 1997.

BANDEIRA DE MELLO, Celso Antônio. Conteúdo jurídico do princípio da igualdade. 3. ed. São Paulo: Malheiros Ed., 1999.

BARROSO, Luís Roberto. Interpretação e aplicação da Constituição: fundamentos de uma dogmática constitucional transformada. 6. ed. São Paulo: Saraiva, 2004.

BASTOS, Celso Ribeiro. Curso de direito financeiro e tributário. São Paulo: Saraiva, Saraiva, 1992.

; GANDRA MARTINS, Ives. Comentários à Constituição do Brasil. São Paulo: Saraiva, 1988. v. 1.

BECK, Ulrich. Risk society: towards a new modernity. London: SAGE Publications, 2011.

BECKER, Alfredo Augusto. Teoria geral do direito tributário. 3. ed. São Paulo: Lejus, 2002.

BELCHIOR, Germana Parente Neiva. Hermenêutica jurídica ambiental. São Paulo: Saraiva, 2011.

BENCHIMOL, Samuel. A Amazônia e o terceiro milênio. Parcerias Estratégicas, Brasília, n. 9, p. 22-34, out. 2000.

BENJAMIN, Antonio Herman V. O princípio do poluidor-pagador e a reparação do dano ambiental. In: Benjamin, Antonio Herman V. (Coord.). Dano ambiental: prevenção, reparação e repressão. São Paulo: Ed. Revista do Tribunais, 2003.

BERCOVICI, Gilberto. Constituição Econômica e desenvolvimento: uma leitura a partir da Constituição de 1988. São Paulo: Malheiros Ed., 2005.

. Soberania e Constituição: para uma crítica do constitucionalismo, Quartier Latin, 2008.

BOBBIO, Norberto. O conceito de sociedade civil. Rio de Janeiro: Edições Graal, 1982. . A era dos direitos. 19. tir. São Paulo: Ed. Campus, 2004.

BÖHRINGER, Christoph; FINUS, Michael. The Kyoto Protocol: sucess or failure? In: HELM, Dieter (Ed.). Climate-change policy. Oxford: Oxford University Press, 2005. 
BOKOBO MOICHE, Susana. Gravámenes e incentivos fiscales ambientales. Madrid: Civitas, 2000.

BORGES NETTO, André Luiz. A defesa do meio ambiente como princípio da ordem econômica. Cadernos de Direito Constitucional e Ciência Política, São Paulo, v. 3, n. 11, p. 146-175, abr./jun. 1995.

BORRERO MORO, C. La tributación ambiental en España. Tecnos, 1999.

BRAGA FILHO, Edson de Oliveira (Coord.). Sustentabilidade e cooperativismo: uma filosofia para o amanhã. Belo Horizonte: Ed. Fórum, 2011.

BREUER, Umweltschutzrecht. In: SCHMIDT-ASSMANN, Eberhard; SCHOCH, Friedrich (Hrsg.). Besonderes Verwaltungsrecht. 14. Aufl. Berlin 2008. S. 596-779.

BUSH, Mark B.; FLENLEY, John R.; GOSLING, Willian (Eds.). Tropical rainforest responses to climatic change. London; New York: Springer, 2007.

CABRAL, Armando. Direito ao meio ambiente como direito fundamental constitucionalizado. Revista de Direito Agrário e Meio Ambiente, Curitiba, v. 2, n. 2, p. 812, ago. 1987.

CAMARGO, Aspásia; CAPOBIANCO, João Paulo R.; OLIVEIRA, José Antonio Puppim de. Os desafios da sustentabilidade no período pós-Rio-92. In:

(Orgs.). Meio ambiente Brasil: avanços e obstáculos pós-Rio-92. Rio de Janeiro: Fundação Getúlio Vargas, 2002.

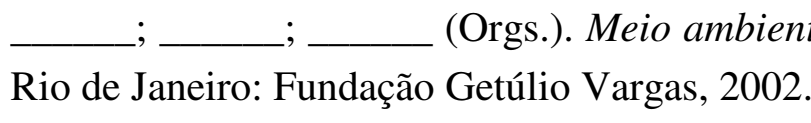

CANOtIlHO, J. J. Gomes. Constituição dirigente e vinculação do legislador. 2. ed. Coimbra: Coimbra, 2001

. Direito constitucional e teoria da Constituição. Coimbra: Coimbra Ed., 1997.

; LEITE, José Rubens Morato (Org.). Direito constitucional ambiental brasileiro. São Paulo: Saraiva, 2007.

CARDOZO, José Eduardo M.; QUEIROZ, João Eduardo L.; SANTOS, Márcia Walquíria B. dos (Orgs.). Curso de direito administrativo econômico. São Paulo: Malheiros Ed., 2010 .

CARNEIRO, Ricardo. Direito ambiental: uma abordagem econômica. Rio de Janeiro: Forense, 2003. 
CARRARO, Carlo (Org.). Efficiency and equity of climate change policy. Reino Unido: Kluver Academic Publishers, 2000.

CARRAZZA, Roque Antonio. Curso de direito constitucional tributário. 16. ed. São Paulo: Malheiros Ed., 2001.

. Curso de direito constitucional tributário. 24. ed. São Paulo: Malheiros Ed., 2008. .. ICMS. 4. ed. São Paulo: Malheiros Ed., 1998.

CARVAlHO, Paulo de Barros. Curso de direito tributário. 13. ed. São Paulo: Saraiva, 2000.

. Sobre os princípios constitucionais tributários. Revista de Direito Tributário, São Paulo, v. 15, n.55, p. 143-155, jan./mar. 1991.

CENEVIVA, Walter. Direito constitucional brasileiro. São Paulo: Saraiva, 1989.

COELHO, Fabio Ulhoa. Para entender Kelsen. 2. ed. São Paulo: Max Limonad, 1996.

COELHO, Sacha Calmon Navarro. Manual de direito tributário. Rio de Janeiro: Forense, 2001.

COIMBRA, José de Ávila Aguiar. O outro lado do meio ambiente. São Paulo: Ed. Millenium, 2002.

COMISSÃO MUNDIAL SOBRE MEIO AMBIENTE E DESENVOLVIMENTO. Nosso Futuro Comum. 2. ed. Rio de Janeiro: FGV, 1991.

COMPARATO, Fábio Konder. Fundamento dos direitos humanos. Revista Jurídica Consulex. Brasília, ano 4, n. 48, p. 52-61, dez. 2000.

COSTA NETO, Nicolao Dino de Castro e. Proteção jurídica do meio ambiente. Belo Horizonte: Del Rey, 2003.

CRETELLA JUNIOR, José. Comentários à Constituição brasileira de 1988. 1. ed. Rio de Janeiro: Forense Universitária, 1989. v. 1.

DALLARI, Dalmo de Abreu. Elementos de teoria geral do Estado. 29. ed. São Paulo: Saraiva, 2010.

DANIEL, Philip; KEEN, Michael; McPHERSON, Charles. The taxation of petroleum and minerals: principles, problems and practice. London; New York: Routledge, 2010.

DENARI, Zelmo. O tributo a serviço da natureza. Revista Tributária e de Finanças Públicas, São Paulo, v. 9, n. 36, p. 54-61, jan./fev. 2001.

DERANI, Cristiane. Direito ambiental econômico. São Paulo: Max Limonad, 1997. 
DERANI, Cristiane. Direito ambiental econômico. 2. ed., 3. tir. São Paulo: Saraiva, 2009.

DIAMOND, Jared. Colapso: como as sociedades escolhem o fracasso ou o sucesso. 5. ed. Rio de Janeiro: Record, 2007.

Gun, germs, and steel: the fates of human societies. New York: W.W. Norton \& Company, 1999.

DIAS, Genebraldo Freire. Educação ambiental: princípios e práticas. 6. ed. São Paulo: Gaia, 2000.

DIEGUES, Antonio Carlos. A globalização da proteção da natureza: o papel das grandes ONGs transnacionais e da ciência. In: DUPAS, Gilberto (Org.). Meio ambiente e crescimento econômico: tensões estruturais. São Paulo: Ed. UNESP; Instituto de Estudos Econômicos e Internacionais, 2008.

DOMINGUES, José Marcos. Direito tributário e meio ambiente. 3. ed. Rio de Janeiro: Forense, 2007.

DUPAS, Gilberto (Org.). Meio ambiente e crescimento econômico: tensões estruturais. São Paulo: Ed. UNESP; Instituto de Estudos Econômicos e Internacionais, 2008.

ELALI, André. Tributação e regulação econômica: um exame da tributação como instrumento de regulação econômica das desigualdades regionais. São Paulo: MP Ed., 2007.

ERBGUTH, Wilfried; SCHLACKE, Sabine. Umweltrecht. 2. Auf. Baden-Baden, 2008.

ERIKSSON, Asbjörn; HERTZOG, Robert; TILEY, John; WILLIAMS, David; ZEZSCHWITZ, Friedrich von. Taxation for environmental protection, New York: Quorum Books, 1991.

ESPÍNDOLA, Ruy Samuel. Conceito de princípios constitucionais. São Paulo: Ed. Revista dos Tribunais, 1999.

FALCÃO, Raimundo Bezerra. Tributação e mudança social. Rio de Janeiro: Forense, 1981.

FELGUERAS, Santiago. Derechos humanos y médio ambiente. Buenos Aires: Ed. AdHoc, 1996.

FERRAZ JR., Tercio Sampaio. Introdução ao estudo do direito: técnica, decisão, dominação. 2. ed. São Paulo: Atlas, 1996. 
FERREIRA, Angélica de Melo. Aspectos econômicos do direito ambiental. Revista dos mestrandos em Direito Econômico da UFBA, Salvador, Salvador, n.5, p. 319-328, jan./dez. 1996. Edição Especial Direito Ambiental.

FERREIRA, Pinto. Comentários à Constituição brasileira. São Paulo: Saraiva, 1990. v. 1.

A concepção dos direitos individuais e as ilusões constitucionais. Cadernos de Direito Constitucional e Ciência Política, São Paulo, v.1, n.1, p. 274-281, out./dez. 1992.

FERREIRA FILHO, Manoel Gonçalves. Comentários à Constituição brasileira de 1988. São Paulo: Saraiva, 1990. v. 1.

FIGUEIREDO, Guilherme José Purvin de. A propriedade no direito ambiental. 4. ed. São Paulo: Ed. Revista dos Tribunais, 2010.

; LEUZINGER, Márcia Dieguez. Desapropriações ambientais na Lei 9.985/2000. In: BENJAMIN, Antonio Herman (Coord.). Direito ambiental das áreas protegidas: o regime jurídico das unidades de conservação. Rio de Janeiro: Forense Universitária, 2001.

FILOMENO, José Geraldo Brito. Manual de teoria geral do Estado e ciência política. 7. ed. Rio de Janeiro: Forense Universitária, 2009.

FIORILlO, Celso Antônio Pacheco. Curso de direito ambiental brasileiro. São Paulo: Saraiva, 2000.

; CARMO, Thaís Maria Leonel do. Desenvolvimento sustentável: a ordem econômica do capitalismo e a questão do meio ambiente na Constituição Federal de 1988 Art. 170, VI. In: MARQUES, José Roberto (Org.). Sustentabilidade e temas fundamentais de direito ambiental. São Paulo: Millenium, 2009.

; FERREIRA, Renata Marques. Direito ambiental tributário. São Paulo: Saraiva, 2005.

; MORITA, Dione Mari; FERREIRA, Paulo. Licenciamento ambiental. São Paulo: Saraiva, 2011.

FLUCK, Jürgen; THEUER, Andreas. Umwelt Informationsfreiheitsrecht mit Umweltinformations- und Verbraucherinformationsrecht. Loseblatt: Heidelberg, 2003.

FOX-PENNER, Peter. Smart power: climate change, the smart grid, and the future of electric utilities. Washington: Island Press, 2009.

FREITAS, Juarez. Sustentabilidade: direito ao futuro. Belo Horizonte: Ed. Fórum, 2011. 
FREITAS, Rômulo de Jesus Dieguez de. Imposto, uma perspectiva ecológica. In: SIMPÓSIO DE ADMINISTRAÇÃO TRIBUTÁRIA, 2. out. 1993. Porto Alegre, 1993.

FREITAS, Vladimir Passos de. A Constituição Federal e a efetividade das normas ambientais. São Paulo: Ed. Revista dos Tribunais, 2000.

FRENCH, Duncan. International law and policy of sustainable development. Juris Publishing, Manchester University Press, 2005.

FURLAN, Melissa. Mudanças climáticas e valoração econômica da preservação ambiental. Curitiba: Juruá, 2010.

GARCIA, Beatriz. The Amazon from an international law perspective. Cambridge: Cambridge University Press, 2011.

GARCIA, Maria da Glória F.P.D. O lugar do direito na protecção do ambiente. Coimbra: Almedina, 2007.

GIMÉNEZ, Teresa Vicente. Justicia ecológica y protección del medio ambiente. Madrid: Ed. Trotta, 2002.

GOLDEMBERG, José. Artigo-base sobre energia. In: CAMARGO, Aspásia; CAPOBIANCO, João Paulo R.; OLIVEIRA, José Antonio Puppin de (Orgs.). Meio ambiente Brasil: avanços e obstáculos pós-Rio-92. Rio de Janeiro: Fundação Getúlio Vargas, 2002.

GOMES, Carla Amado. Textos dispersos de direito do ambiente. AAFDL, 2008. v. 1.

GOMES, Luis Roberto. O princípio da função social da propriedade e a exigência constitucional de proteção ambiental. Revista de Direito Ambiental, São Paulo, v.5, n.17, p. 160-178, jan./mar. 2000.

GRANZIERA, Maria Luiza Machado. Direito ambiental. São Paulo: Atlas, 2009.

GRASSETTI, Eduardo R. Estudios ambientales. 1. ed. Buenos Aires: Editorial Heliasta, 1998.

GRAU, Eros Roberto. O direito posto e o direito pressuposto. 3. ed. São Paulo: Malheiros Ed., 2000.

Ensaio e discurso sobre a interpretação/aplicação do direito. 5. ed. São Paulo: Malheiros Ed., 2009.

A ordem econômica da Constituição de 1988: interpretação e crítica. 3. ed. São Paulo: Malheiros Ed., 1999. 
GRAU, Eros Roberto. A ordem econômica na Constituição de 1988. 7. ed. São Paulo: Ed. Revista dos Tribunais, 2002.

. In: NUNES, António José; COUTINHO, Jacinto Nelson de (Orgs.). O direito e o futuro - o futuro do direito. Coimbra: Almedina, 2008.

GRAU NETO, Werner. Novos paradigmas sociais e econômicos do direito ambiental. In: BRAGA FILHO, Edson de Oliveira (Coord.). Sustentabilidade e cooperativismo: uma filosofia para o amanhã. Belo Horizonte: Ed. Fórum, 2011.

O Protocolo de Quioto e o Mecanismo de Desenvolvimento Limpo - MDL: uma análise crítica do instituto. São Paulo: Fiúza, 2006.

GRECO, Marco Aurélio. Contribuições de intervenção no domínio econômico parâmetros para sua criação. In:___ (Coord.). Contribuições de intervenção no domínio econômico e figuras afins. São Paulo: Dialética, 2001.

(Coord.). Contribuições de intervenção no domínio econômico e figuras afins. São Paulo: Dialética, 2001.

GRINOVER, Ada Pelegrini. A defesa do meio ambiente em juízo como conquista da cidadania. Universidade de Coimbra, Portugal-Brasil ano 2000. Tema Direito. Coimbra: Coimbra Ed., 1999.

GUIMARÃES, Roberto P. Ecologia e política na formação social brasileira. Dados: revista de ciências sociais, Rio de Janeiro, v. 1, n. 2, 1988.

HABERMAS, Jürgen. Direito e democracia entre facticidade e validade. Rio de Janeiro: Templo Brasileiro, 1997. v. 1.

HANDLEY, Nick et al. Environmental economics in theory and practice. 2. ed. New York: Palgrave Macmillian, 2007.

HANSMANN, Klaus; SELLNER, Dieter (Hrsg.). Grundzüge des Umweltrechts. 3. Aufl. Berlin, 2007.

HELLER, Agnes; FEHÉR, Ferenc. A condição política pós-moderna. 2. ed. Rio de Janeiro: Civilização Brasileira, 2002.

HOBSBAWN, Eric. Era dos extremos: o breve século XX - 1914-1991. 2. ed. 9. reimpr. São Paulo: Compahia das Letras, 1997.

HOPPE, Werner; BECKMANN, Martin; KAUCH, Petra. Umweltrecht. 2. Aufl. München, 2000. 
JAQUENOD DE ZSÖGÖN, Silvia. El derecho ambiental y sus principios rectores. Madrid: Dykinson, 1991.

JARASS, Hans Dieter. Bundes-Immissionsschutzgesetz. 7. Aufl. München 2007.

JELLINEK, G. Teoría general del Estado. Traducción por Fernando de Los Ríos Urruti. Granada, Editorial Comares, 2000.

KELSEN, Hans. Teoria geral do direito e do Estado. 3. ed. São Paulo: Martins Fontes, 2000 .

. Teoria pura do direito. 6. ed. São Paulo: Martins Fontes, 2003.

KENNEDY, Paul. Preparando para o século XXI. São Paulo: Ed. Campus, 1993.

KIRCHGÄSSNER, Gebhard; SCHNEIDER, Friedrich. On the political economy of environmental policy. St. Gallen: University of St., 2001. (Discussion paper no. 2001-20).

KISHI, Sandra A. K.; SILVA, Solange T. da; SOARES, Inês V. P. (Orgs.) Desafios do direito ambiental no século XXI: estudos em homenagem a Paulo Affonso Leme Machado. São Paulo: Malheiros Ed., 2005.

KISS, Alexandre. Sustainble development and human rights. In: TRINDADE, Antonio Augusto Cançado. Direitos humanos, desenvolvimento sutentável e meio ambiente. San Jose da Costa Rica; Brasília: BID, 1992. p. 29-37.

KLOEPFER, Michael. Umweltrecht. 3. Aufl. München: C.H. Beck, 2004. . Umweltschutzrecht. München: C.H. Beck, 2008.

KOCH, Hans-Joachim (Hrsg.). Umweltrecht. 2. Aufl. München: Carl Heymanns, 2007.

LAGO, André Aranha Corrêa. Estocolmo, Rio, Joanesburgo: o Brasil e as três Conferências Ambientais das Nações Unidas. Brasília: Instituto Rio Branco; Fundação Alexandre de Gusmão, 2007.

LANGE, Maria Bernadete Ribas. A conservação da natureza: conceitos e breve histórico. VEIGA RIOS, Aurélio Virgílio; HUGUENEY IRIGARAY, Carlos Teodoro (Orgs.). $O$ direito e o desenvolvimento sustentável. São Paulo: Peirópolis, 2005.

LOCKE, John. Segundo Tratado sobre o governo. São Paulo: Martin Claret, 2002.

LÓPEZ RAMÓN, Fernando. El derecho ambiental como derecho de la función pública de protección de los recursos naturales. In: VALLE MUÑIZ, José Manuel (Org.). La protección jurídica del medio ambiente. Navarra: Aranzadi, 1997. 
LOVELOCK, James. A vingança de Gaia. Rio de Janeiro: Ed. Intrínseca, 2006.

LUQUE BUSTAMANTE, Javier. Algunas reflexiones sobre las relaciones entre los derechos humanos y la tributacion. Revista de Direito Tributário, São Paulo, v. 14, n. 52, p. 54-65, abr./jun. 1990.

MACHADO, Paulo Affonso Leme. Princípios gerais do direito ambiental internacional e a política ambiental brasileira. In: BENJAMIN, Antonio Herman V. (Coord.). Dano ambiental: prevenção, reparação e repressão. São Paulo: Ed. Revista dos Tribunais, 1993.

MAINON, Dalia. Mudança da política ambiental. In: MACIEL, Tania (Org.). O ambiente inteiro: a contribuição crítica da universidade à questão ambiental. Rio de Janeiro: UFRJ, 1992.

MARCHELLO, Francesco; PERRINI, Marinella; SERAFINI, Susy. Diritto dell'ambiente. São Paulo: Simone, 2007.

MARQUES, José Roberto. Sustentabilidade e temas fundamentais de direito ambiental. São Paulo: Ed. Millennium, 2009.

MARSHALL, Alfred. Principles of economics. London: MacMillan, 1920.

MAXIMILIANO, Carlos. Hermenêutica e aplicação do direito. 4. ed. Rio de Janeiro: Freitas Bastos, 1947.

MEADOWS, Donella; RANDERS Jorgen; MEADOWS Dennis. Limites do crescimento: a atualização de 30 anos. São Paulo: Qualitymark, 2007.

MEDEIROS, Antonio Paulo Cachapuz de. O poder de celebrar tratados: competência dos poderes constituídos para celebração de tratados à luz do direito internacional, do direito comparado e do direito constitucional brasileiro. Porto Alegre: Sergio Antonio Fabris Editor, 1995.

MELLO, Celso D. de Albuquerque. Direito internacional econômico. Rio de Janeiro: Renovar, 1993.

MENDELSOHN, Robert. The social costs of greenhouse gases: their values and policy implications. In: HELM, Dieter (Ed.). Climate-change policy. Oxford: Oxford University Press, 2005.

MENDES, Gilmar F., COELHO, Inocêncio M, BRANCO, Paulo Gustavo G. Hermenêutica constitucional e direitos fundamentais. Brasília: Brasília Jurídica, 2000.

MILARÉ, Edis. Direito do ambiente. 4. ed. São Paulo: Ed. Revista dos Tribunais, 2005. 
MILARÉ, Edis; COIMBRA, José de Ávila Aguiar. Antropocentrismo x ecocentrismo na ciência jurídica. Revista de Direito Ambiental, São Paulo, v. 36, p. 9-41, out./dez. 2004.

MODÉ, Fernando Magalhães. Tributação ambiental: a função do tributo na proteção do meio ambiente. 5. reimpr. Curitiba: Juruá, 2007.

MORAES, Alexandre de. Direito constitucional. 7. ed. São Paulo: Atlas, 2000.

MORRIS, Ian. Why the west rules: for now. Londres: Profile Books, 2010.

MOTA, Maurício (Coord.). Função social do direito ambiental. Rio de Janeiro: Elsevier, 2009.

NABAIS, José Casalta. Reforma tributária num estado fiscal suportável. In: NUNES, António José; COUTINHO, Jacinto Nelson de (Orgs.). O direito e o futuro - o futuro do direito. Coimbra: Almedina, 2008.

Tributos com fins ambientais. Revista Tributária e de Finanças Públicas, São Paulo, ano 16, v. 80, p. 253-280, maio/jun. 2008.

NALINI, Renato. Ética ambiental. 2. ed. São Paulo: Ed. Millenium, 2003.

NASSER, Salem Hikmat. Fontes e normas do direito internacional: um estudo sobre a soft law. São Paulo: Atlas, 2005.

NUSDEO, Ana Maria de Oliveira. Pagamento por serviços ambientais no Brasil: elementos para uma regulamentação ambientalmente íntegra e socialmente justa. 2010. Tese (Livre Docência) - Faculdade de Direito, Universidade de São Paulo, São Paulo, 2010.

NUSDEO, Fábio. Curso de economia: introdução ao direito econômico. São Paulo: Ed. Revista dos Tribunais, 1997.

. Curso de economia: introdução ao direito econômico. 3. ed. São Paulo: Ed. Revista dos Tribunais, 2001.

Desenvolvimento e ecologia. Justitia, São Paulo, v. 47, n. 128, p. 52-59, jan./mar. 1985.

OLIVA JÚNIOR, José Roberto. Estruturas societárias e contratuais em project finance com foco em empreendimentos de geração de energia elétrica no Brasil. São Paulo, 2011. Monografia (Especialização em Direito Societário e Especialização em Direito do Mercado Financeiro e de Capitais - LLM Master of Laws) - Instituto de Ensino e Pesquisa (Insper), São Paulo, 2011. 
OLIVEIRA, Amanda Flávio de (Coord.). Direito econômico: evolução e institutos. Rio de Janeiro: Forense, 2009.

OST, François. A natureza à margem da lei: a ecologia à prova do direito. Lisboa: Instituto Piaget, 1995.

PADILHA, Norma Sueli. Fundamentos constitucionais do direito ambiental brasileiro. Rio de Janeiro: Elsevier, 2010.

PÁDUA, Cláudio Valadares; CHIARAVALLOTI, Rafael Morais. Escolhas sustentáveis: discutindo biodiversidade, uso da terra, água e aquecimento global. São Paulo: Ed. Urbana, 2011.

PÁDUA, José Augusto. Um sopro de destruição: pensamento político e crítica ambiental no Brasil escravista (1786/1888). 2. ed. Rio de Janeiro: Jorge Zahar, 2004.

PASTORINO, Leonardo Fabio. El daño al ambiente. Lexis Nexis, 2005.

PEARCE, David. The social cost of carbon. In: HELM, Dieter (Ed.). Climate-change policy. Oxford: Oxford University Press, 2005.

PIGRETTI, Eduardo A. Derecho ambiental. Buenos Aires: Depalma, 2000.

PIOVESAN, Flávia. Direitos humanos e o direito constitucional internacional. 3. ed. São Paulo: Max Limonad, 1997.

- Federalização dos crimes contra os direitos humanos. Revista Brasileira de Ciências Criminais, São Paulo, ano 13, v. 54, p. 169-183, maio/jun. 2005.

PIVA, Rui Carvalho. Bem ambiental. São Paulo: Max Limonad, 2000.

PORENA, Daniele. La protezione dell'ambiente tra Costituzione italiana e "Costituzione globale” Torino: G. Giappichelli, 2009. (Collana di Studi di Diritto Pubblico).

RECH, Adir Ubaldo; ALTMANN, Alexandre. Pagamento por serviços ambientais: Imperativos jurídicos e ecológicos para a preservação e a restauração das matas ciliares, Caxias do Sul: Ed. da Universidade de Caxias do Sul, 2009.

REI, Fernando; CUNHA, Kamyla Borges da. Cadernos NAE, Núcleo de Assuntos Estratégicos da Presidência da República, Brasília, n. 4, abr. 2004.

RENGELING, Hans-Werner (Hrsg.). Handbuch zum europäischen und deutschen Umweltrecht. 2 Bände. 2. Aufl. Köln/Berlin/München, 2002.

REZENDE, Divaldo; MERLIN Stefano. Social carbon: adding value to sustainable development. Instituto Ecológica, 2003. 
RIBAS, Lídia Maria L. R; CARVALHO, Valbério Nobre de. O tributo como instrumento de tutela do meio ambiente. Revista de Direito Ambiental, São Paulo, v. 14, n. 54, p. 185204, abr./jun. 2009.

RIBEIRO, Wagner Costa. A ordem ambiental internacional. São Paulo: Ed. Contexto, 2001.

ROHDE, Geraldo Mario. Economia ecológica da emissão antropogênica do CO2: uma abordagem filosófico-científica sobre a efetuação humana alopoiética da terra em escala planetária. Porto Alegre: Instituto de Biociências da Universidade Federal do Rio Grande do Sul, 2003.

SANDS, Philippe. Principles of international environmental law. 2. ed. Cambridge: Cambridge University Press, 2003.

SANTILLI, Juliana. Socioambientalismo e novos direitos: proteção jurídica à diversidade biológica e cultural. Editora Peirópolis, 2005. In:: WOLKMER, Antonio Carlos; LEITE, José Rubens Morato (Orgs.). Os “novos" direitos no Brasil: natureza e perspectivas. São Paulo: Saraiva, 2003.

SANTOS, Roberto. Ética ambiental e funções do direito ambiental. Revista de Direito Ambiental, São Paulo, v. 5, n. 18, p. 241-250, abr./jun. 2000.

SCAFF, Fernando Facury. Notas sobre o princípio do desenvolvimento econômico e da preservação do meio ambiente e a responsabilidade por dano ambiental. Revista de Direito Comparado, Belo Horizonte, v. 3, p. 255-267, maio 1999.

; TUPIASSU, Lise Vieira da C. Tributação e políticas públicas: o ICMS ecológico. Verba Juris, João Pessoa, ano 3, n. 3, p. 151-187, jan./dez. 2004.

SCAFF, Fernando Facury; ATHIAS, Jorge Alex (Orgs.). Direito tributário e econômico aplicado ao meio ambiente e à mineração. São Paulo: Quartier Latin, 2009.

SCHLEGELMILCH, Kai (Org.). Green budget reform in Europe: countries at the forefront. New York: Springer, 1999.

SCHMIDT, Reiner; KAHL, Wolfgang. Einführung in das Umweltrecht. 7. Aufl. München, 2006.

SCHOUERI, Luís Eduardo. Normas tributárias indutoras e intervenção econômica. Rio de Janeiro: Forense, 2005.

SCHWARTMANN, Rolf. Umweltrecht. Heidelberg, 2006.

SÉGUIN, Elida. O direito ambiental: nossa casa planetária. 2. ed. Rio de Janeiro: Forense, 2002. 
SERRANO, José Luis. Principios de derecho ambiental y ecología jurídica. Madrid: Ed. Trotta, 2007.

SILVA, Américo Luís Martins da. Direito do meio ambiente e dos recursos naturais. São Paulo: Ed. Revista dos Tribunais, 2005.

SILVA, Geraldo Eulálio do Nascimento e. Direito ambiental internacional. Rio de Janeiro: Thex Ed., 1995.

Direito ambiental internacional. 2. ed. Rio de Janeiro: Thex Ed., 2002.

SILVA, José Afonso da. Direito ambiental constitucional. 2. ed. rev. São Paulo: Malheiros Ed., 1995.

. Direito ambiental constitucional. 4. ed. rev. São Paulo: Malheiros Ed., 2002.

SILVA, Solange Teles da. Reflexões sobre o ICMS ecológico. In: KISHI, Sandra A. K.; SILVA, Solange T. da; SOARES, Inês V. P. (Orgs.) Desafios do direito ambiental no século XXI: estudos em homenagem a Paulo Affonso Leme Machado. São Paulo: Malheiros Ed., 2005. p. 753-776.

SIMONE, Diego Caldas Rivas de. Segurança jurídica e tributação: da certeza do direito à proteção da confiança legítima do contribuinte. São Paulo: Quartier Latin, 2011.

SIVERA, J. Perreló. Economia ambiental. Universidad de Alicante, 1996.

SMERALDI, Roberto. O novo manual de negócios sustentáveis. São Paulo: Publifolha, 2009.

SOARES, Claudia Dias. O imposto ambiental: direito fiscal do ambiente. Coimbra: Almedina, 2002.

SOARES, Guido Fernando Silva. Curso de direito internacional público. São Paulo: Atlas, 2002. v. 1.

SOARES, Remi Aparecida de Araújo. Proteção ambiental e desenvolvimento econômico: conciliação. Curitiba: Juruá, 2004.

SOUSA, Washington Albino Peluso de. Primeiras linhas de direito econômico. 4. ed. São Paulo: LTr, 1999.

SOUZA, Jorge Henrique de Oliveira. Tributação e meio ambiente. Belo Horizonte: Del Rey, 2009.

SPARWASSER, Reinhard; ENGEL, Rüdiger; VOSSKUHLE, Andreas. Umweltrecht, Grundzüge des öffentlichen Umweltschutzrechts. 5. Aufl. Heidelberg, 2003. 
STERN, Nicholas. $O$ desafio global: como enfrentar as alterações climáticas criando uma nova era de progresso e prosperidade. Campo Grande: Ed. Esfera do Caos, 2009.

. The economics of climate change: the stern review. Cambridge: Cambridge University Press, 2007.

TEIXEIRA, Sálvio de Figueiredo. O meio ambiente, a urbanização e a prevenção dos conflitos no Brasil. Revista Jurídica Consulex. Brasília, ano 4, n. 46, p. 14-20, out. 2000.

TEPEDINO, Gustavo José Mendes. A questão ambiental, o ministério público e as ações civis públicas. Scientia Juris: revista do curso de mestrado em direito negocial da UEL. Londrina: UEL, v.4, p. 114-148, 2000.

TEROL BECERRA, Manuel José. Espacios naturalez protegidos y medio ambiente. Madrid: Centro de Estudios Políticos y Constitucionales, 2002.

THIEFFRY, Patrick. Direito Europeu do ambiente. Lisboa: Instituto Piaget, 1998.

TOLMASQUIM, Mauricio M. Novo modelo do setor elétrico brasileiro. Rio de Janeiro: Ed. Synergia, 2011.

TÔRRES, Heleno Taveira. Da relação entre competências constitucionais tributária e ambiental - os limites dos chamados "tributos ambientais". In: (Org.). Direito ambiental tributário. São Paulo: Malheiros Ed., 2005.

A proteção a áreas degradadas por atividades relacionadas à indústria do petróleo e do gás e seus derivados e o emprego da CIDE-Combustíveis. In: SCAFF, Fernando Facury; ATHIAS, Jorge Alex (Coords.). Direito tributário e econômico aplicado ao meio ambiente e à mineração. São Paulo: Quartier Latin, 2009.

Segurança jurídica do sistema constitucional tributário. 2011. Tese (Titular) Faculdade de Direito, Universidade de São Paulo, São Paulo, 2011.

(Org.). Direito ambiental tributário. São Paulo: Malheiros Ed., 2005.

TÔRRES, Ricardo Lobo. A idéia de liberdade no Estado patrimonial e no Estado fiscal. Rio de Janeiro: Renovar, 1991.

TRENNEPOHL, Terrence Dorneles. Incentivos fiscais no direito ambiental para uma matriz energética limpa e o caso do etanol brasileiro. 2. ed. São Paulo: Saraiva, 2011.

TRIGUEIRO, André (Coord.). Meio ambiente no século 21. 2. ed. São Paulo: Ed. Sextante, 2003. 
TRINDADE, Antonio Augusto Cançado. Meio ambiente e desenvolvimento: formulação, natureza jurídica e implementação do direito ao desenvolvimento como um direito humano. Revista da Procuradoria Geral do Estado do Ceará, Fortaleza, v. 9, n. 11, p. 1142, 1992.

TUPIASSU, Lise Vieira da Costa. Tributação ambiental: a utilização de instrumentos econômicos e fiscais na implementação do direito ao meio ambiente saudável. Rio de Janeiro: Renovar, 2006.

VAN STADE, Maryke; Musco, Francesco (Org.). Local governments and climate change: sustainable energy planning and implementation in small and medium sized communities. New York: Springer, 2010.

VEIGA RIOS, Aurélio Virgílio; HUGUENEY IRIGARAY, Carlos Teodoro (Orgs.). $O$ direito e o desenvolvimento sustentável. São Paulo: Peirópolis, 2005.

VEJA, São Paulo, ano 44, n. 49, ed. 07 dez. 2011. p. 21.

VETTTER, HENRIK. Environmental taxes in monopolistics competition. Aarhus: University of Aarhaus, 2001. 29 p. (Working Paper nº 2001-13).

VILLELA SOUTO, Marcos Juruena. Estímulos positivos. In: CARDOZO, José Eduardo M.; Queiroz, João Eduardo L.; SANTOS, Márcia Walquíria B. dos (Orgs.). Curso de direito administrativo econômico. São Paulo: Malheiros Ed., 2010. v. 2.

VOGEL, Klaus. Steuergerechtigkeit und soziale Gestlung. Deutsche Steuerzeitung, Oktober, 1975.

WELFENS, Paul J.J.; MEYER, Bernd; PFAFFENBERGER, Wolfgang; JASINSKI, Piotr; JUNGMITTAG, Andre. Energy policies in the European Union: Germany' ecological tax reform. New York: Springer, 2001.

YAMIN, Farhana; DEPLEDGE, Joanna. The international climate change regime: a guide to rules, institutions and procedures. Cambridge University Press, 2004.

YOSHIDA, Consuelo Yatsuda Moromizato. A efetividade e a eficiência ambiental dos instrumentos econômico-financeiros e tributários: ênfase na prevenção: a utilização econômica dos bens ambientais e suas implicações. In: TÔRRES, Heleno Taveira (Org.). Direito tributário ambiental. São Paulo: Malheiros Ed., 2005.

ZANETTI, Eder. Meio ambiente: setor florestal. 2. ed. Curitiba: Juruá, 2009. 